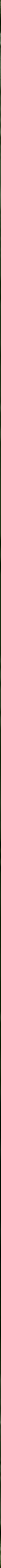



$\%$

$$
\begin{gathered}
\text { Plymouth } \\
\text { IQHAd? }
\end{gathered}
$$


Digitized by the Internet Archive in 2008 with funding from Microsoft Corporation 


\section{OLD PLYMOUTH TRAILS}



THE NEW YORK PUBLIC LIBRARY

ASTOR, LENOX

TILDEN FOUNDATIONS 


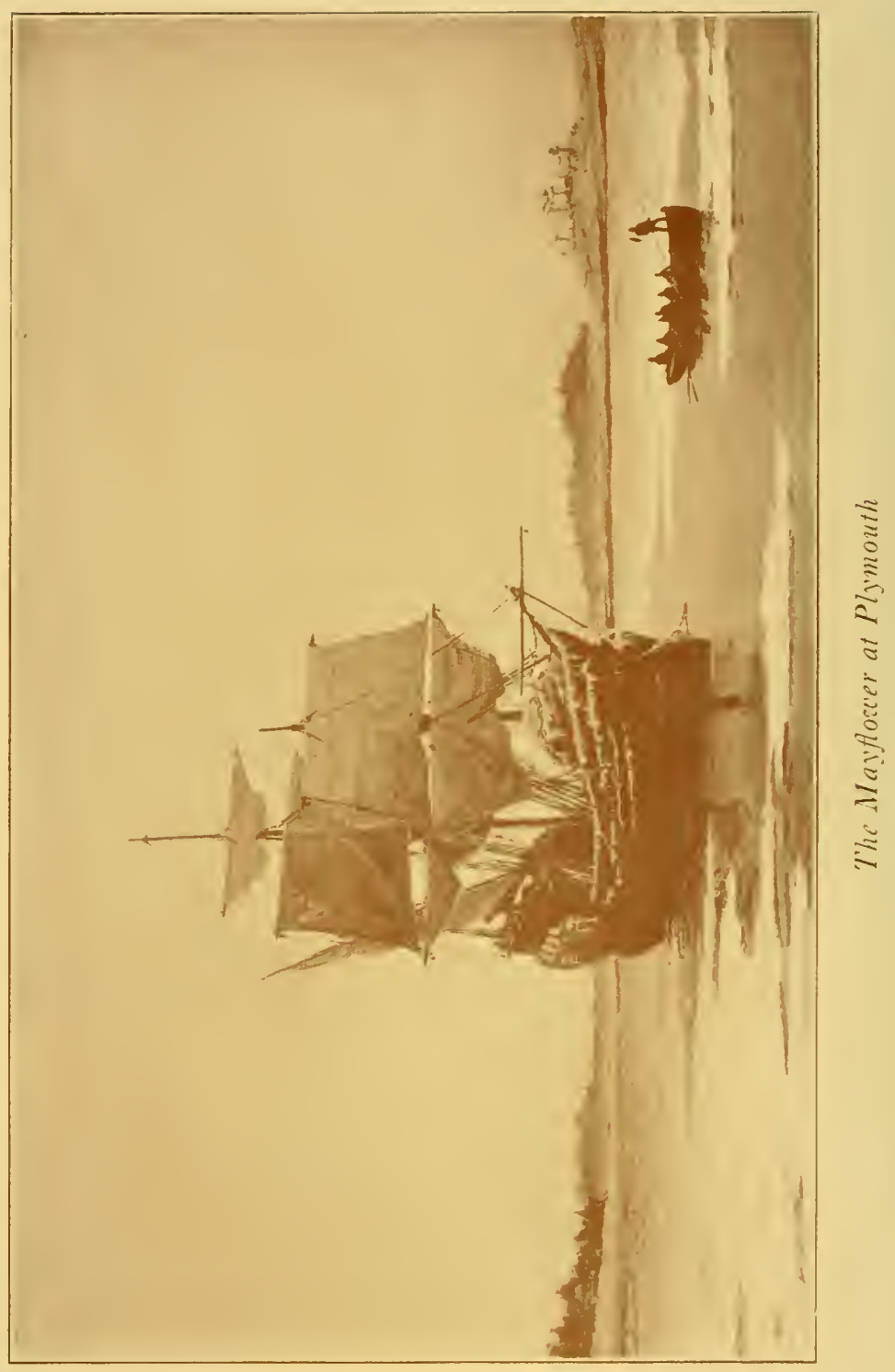




\title{
OLD PLYMOUTH TRAILS
}

\author{
BY \\ WINTHROP PACKARD
}

Author of "White Mountain Trails," "Literary

Pilgrimages of a Naturalist," etc.

\section{ILLUSTRATED}

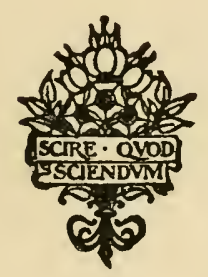

BOSTON

SMALL, MAYNARD \& COMPANY

PUBLISHERS 


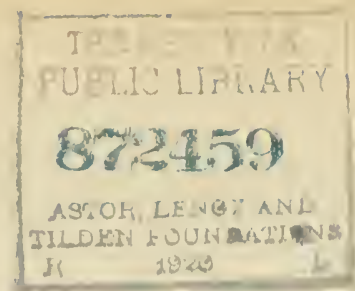

Copyright, 1920,

BY WINTHROP PACKARD

PREg8 OF GEO. H. ELLIS CO., BOSTON 


\section{FOREWORD}

The author wishes to express his thanks to the editors of the Boston Evening Transcript and the Atlantic Monthly for permission to reprint in this volume matter originally contributed to the columns of that paper and magazine; and to A. S. Burbank of Plymouth, I. Chester Horton, and Howard S. Adams for permission to reproduce various illustrations. 



\section{CONTENTS}

CHAPTER PAGE

I Old Plymouth Trails . . . . . . . I

II Plymouth Mayflowers . . . . . . I2

III Unbuilding a Building . • . • 25

IV Forefathers' Day • . • . . . 39

V The Singing Pines . . . . . 52

VI Nantucket in April . • . . . . 65

VII Footing It Across the Cape . . . . 8I

VIII Wild Apple Trees . . . . . . 94

IX Midsummer Moonlight . . . . . 108

X Turtle-Head and Jewel-Weed • • . 122

XI The Way of a Woodchuck . . . . I36

XII Along the Salt Marshes . . . . I49

XIII Fishing "Down Outside" . . . . . I63

XIV Volces of the Brookside • . . . . 177

XV Ghosts of the Northeaster . • . . I87

XVI Jotham Stories . . . . . . . . $20 \mathrm{I}$

XVII Good-Bye to Summer . . . . . . 2 I4

XVili Mystical Pastures . . . . . . . 228

XIX White Pine Groves . . . . . . 242

XX The Pasture in November . . . . 256

XXI Red Cedar Lore . . . . . . . . 270

XXII Aunt Sue's Snowbank . . . . . . 283

XXIII Sports of the Winter Woods . . . 297

XXIV Coasting on Ponkapoag . . . . 3IO

XXV Pickerel Fishing • . . . . . 324

XXVI Yule Fires . • . • • . . • . 339 



\section{ILLUSTRATIONS}

The Mayflower at Plymouth . . . Frontispiece The First Pilgrim Trail . . . . . . . . Opp. 8 Plymouth as the Pilgrims made it . . . ro Leyden Street to-day from Burial Hill . I6 Birds of the Plymouth Woods, Wise and OTHERWISE . . . . . . . . . . 20 Billington Path along the Border of "Billington Sea" . . . . . . . . 42

The Stern and Rock-bound Coast which GREeted the Pilgrims ' . . . . . . . 44

Bayberry and Pitch Pine along a Nantucket Trail . . . . . . . . . 70 A Nantucket Lane . . . . . . . . 78 Along a Byway of the Cape $\quad . \quad$. $\quad . \quad . \quad . \quad 54$ Dusty Miller blossoming among the Cape Dunes . . . . . . . . . . . 86 The Sun sifting and winnowing his Gold FOR SUNSET . . . . . . . . . . IIO SUNRISE OVER THE POND . ROUNDING THE BREAKWATER AT NANTUCKET Within CALL OF THE OLD LISBON BELL . - II6 CAPtain's Hill from Marsh Margin . . . . I3O Along the Salt Marshes . . . . . . ${ }_{15} 6$ OUtward bound IN Plymodth Harbor . . 166 Geese on the Sand Sit at Plymouth . . 180 Wild Geese in Flight over the Pond . . 204 The Fox that SLIPS along the Winding Paths at Dawn . . . . . . . . 260 a Cape Cod Cedar Centuries Old . . . $\quad 274$ The Pines in Winter . . . . . . . . $\quad 286$ Deer in the Winter Woods. . . . . . 300 Pickerel from an Old Colony Pond . . . 326 



\section{OLD PLYMOUTH TRAILS}





\section{OLD PLYMOUTH TRAILS}

\section{CHAPTER I}

\section{OLD PLYMOUTH TRAILS}

"The breaking waves dashed high On a stern and rock-bound coast And the woods against a stormy sky Their giant branches tossed."

So sang Felicia D. Hemans in the early years of the last century and she has been much derided by the thoughtless and irreverent who have said that the landing of the Pilgrims was not on a stern and rock-bound coast. Such scoffers evidently never sailed in by White Horse beach and "Hither Manomet" when a winter northeaster was shouldering the deep sea tides up against the cliff and a surly gale snatched the foam from high-crested waves and sent it singing and stinging inland. Could they have done this it would have been easy to understand that the coast here is stern and rock-bound in very truth. The rocks are not those of solid granite ledges, continuous 
portions of the great earth's lithosphere of which the coast is built farther north, at Scituate, Nahant, Rockport and farther on; but it is rockbound with massed granite boulders, glacier rounded, water-worn, but inexpressibly stern.

All Plymouth is made up of the results of pilgrimage. How many scores of fathoms deep the real Plymouth shore lies I do not know. It is down there somewhere where it cooled into bathylithic crust back in the gray dawn of time when the earth was made. There it is part of the same ledge of which Scituate and Cohasset are built. All above that is terminal moraine, rock detritus piled upon rock foundation by the glacier. Plymouth Rock itself thus came joy riding from some ledge up Boston way, alighting from this first and greatest New England Transportation System only a few hundred thousand years before Mary Chilton arrived to set foot upon it.

Tide and tempest grind pebbles to shifting sand and give and take away beach and bar yearly, but they do not move the boulders very fast. Manomet shore and even Plymouth beach are rock-bound with these, large and small, today as they were when the Pilgrims fought their des- 
perate, sea-beset way by them through the dusk of a winter northeaster and froze in safety under the lee of Clark's Island.

He who would see Plymouth and the Pilgrim land about it as the Pilgrims saw it may do so. Nature holds grimly onto her own and sedulously heals the scars that man makes. Beat to windward in the December twilight following that first trail of the Pilgrim pinnace, listen to the sullen boom of the breakers on the cliff, hear the growl of the surf-mauled pebbles on Plymouth beach, feel the sting of the freezing spray and the bitter grip of the north wind and you shall find this first Pilgrim trail the same today as it was three hundred years ago.

Plymouth is a manufacturing city, a residence town, a resort and a thriving business centre all in one. Except in its carefully preserved shrines you shall find little suggestion of the Pilgrims themselves, but you have only to step out of town to find their very land all about you, traces of their occupancy, the very marks of their feet, worn in the earth itself. A trail cuts easily into the forest mould. Once well worn there centuries fail to remove it. The paths the Pilgrims trod radiate from Plymouth to a score of places 
far and near. They tramped to Sandwich and the canal region, to Middleboro, Bridgewater and Duxbury as we know them now, to Boston; sooner or later to all the world. Some of the trails they trod may be forgotten, some of them are main-travelled highways, others remain narrow footpath ways through a country beautiful and often as unsophisticated as it was when the feet of the first Pilgrims pressed them. Therein lies for all the world the chief charm of the Old Colony region. Along the old Pilgrim trails you may step from modern culture and its acme of civilization through the pasture lands of the Pilgrims into glimpses of the forest primeval. The Pilgrims' boulders, their kettle-hole ponds, mossy swamps and ferny hillsides, here and there their very forest trees, await you still. For Indian and panther you need not look; wolf or bear you will hardly see; the wild turkeys are gone; otherwise the wild life of the forest remains.

The first Pilgrim land trail is today Leyden street, leading from the water's edge to their fort on Burial Hill. You may follow it, though the marks of Pilgrim feet are buried beneath city pavement, save perhaps on the crest of the hill itself, and though bluebird and robin flutter shyly 


\section{OLD PLYMOUTH TRAILS}

to its upper end in spring as did their pilgrim fathers before them, the arbutus, from earliest days to this the Plymouth flower, no longer grows on its margin. He who has not longed to pick a mayflower in Plymouth on Mayday is not a New Englander. That is perhaps why the arbutus no longer grows along byways of the old town as once it did. Instead you must seek the Pilgrim paths out of town to find it.

One of these leads down along shore, over Manomet and on through Plymouth woods toward the old trysting place with the Dutch traders. The men of New Amsterdam, journeying in boats along Long Island Sound and up Buzzards Bay met the Plymouth men yearly and held a most decorous carnival of barter. Tradition has it that the Plymouth men made the trip by sea to the nearest point on the Bay shore. I do not know if the meeting place is known, but I know a moss-grown and gnarled red cedar on the margin of Buttermilk Bay, as we now call it, which I am sure was growing there when the first swapping of commodities took place and in the shade of whose branches the grave and sturdy traders may have sat.

Here and there in Pilgrim land you find a tree 
like that, one that by some chance the axe of the woodman has spared as one generation of wood cutters followed another, that still stands where the seed fell, no man knows how many centuries ago. We have trees in eastern Massachusetts to whom a thousand years is but as yesterday when it is passed, many on which the centuries have rested lightly. I think this Onset cedar one of these.

The road that leads from Plymouth to it is vexed daily by innumerable wheels.; of a summer holiday the wayside watcher may count the motors by the thousand; yet you have but to step a rod or two off its tarred, tire-beaten surface to find wild, woodland as primitive as it was three hundred years ago. The spring seeking motorist finds his first mayflowers there as the grade leads up Manomet heights and may expect them by the roadside anywhere, after that. The old trail to Sandwich saunters along here, but those who built for modern traffic took little heed of old-time footpath ways. They gouged the hills, they filled the hollows and drew their long black scar behind for mile after mile.

Like the deer and the wild fowl the old trails care little for this. They wander on their own 
gentle, untrammelled way, hither and yon, here beset by heavy forest growth, there a tangle of greenbrier and scrub oaks, losing you often, picking you up again when you least expect it, but always leading you off the humdrum highway of today into the gentle wildernesses of old time romance. You find them margined with marks of the pioneer. It may be just a hollow which was once his tiny cellar-hole or a rectangular mound where the logs of his cabin tumbled into the mould, perhaps a moss-grown, weatherbeaten house itself with its barberry bush or its lilac still holding firmly where the pioneer householder set it. These old trails of the Plymouth woods may be just of one family's making, leading from house to pasture and woodlot, or they may be bits of an old-time footpath way first worked out by the Indians themselves no one knows how many centuries ago. Find me an eskar in Plymouth county, a "hogback ridge" as our forbears were wont to call it, and the chances are fair that along its narrow summit edge I'll show you an Indian trail. Sometimes the Pilgrim paths adopted these and later made them roadways.

As you go southward in this region you find 
traces of an ancient type of fencing that I have not seen elsewhere. It may have been a hedgemaker's trick, brought from the old country. The Cape pioneers slashed young white oaks growing along the road margin, bent them, say two feet above the ground, without severing, and laid them level, the tops bound tight with withes to the next trunk. Thus they had a fence that would restrain cattle and that grew stouter as the years went by. You find these trees growing thus today, their trunks a foot or two in diameter, bending at right angles just above ground and stretching horizontally, while what were once limbs now grow trunks from the grotesque butt. A remnant of fence like this along an almost obliterated trail in an ancient wood gives a hobgoblin character to the place.

The heath family, all the way from clethra which begins it to cranberry which ends it, dwells in beauty and diversity all about in the Plymouth woods, making them fragrant the year round. Some of them help feed the world, notably the cranberries and the huckleberries of a score of varieties from the pale, inch high, earliest sweet blueberries growing on the dry hillsides to the giants of the deep swamp, hanging out of reach 


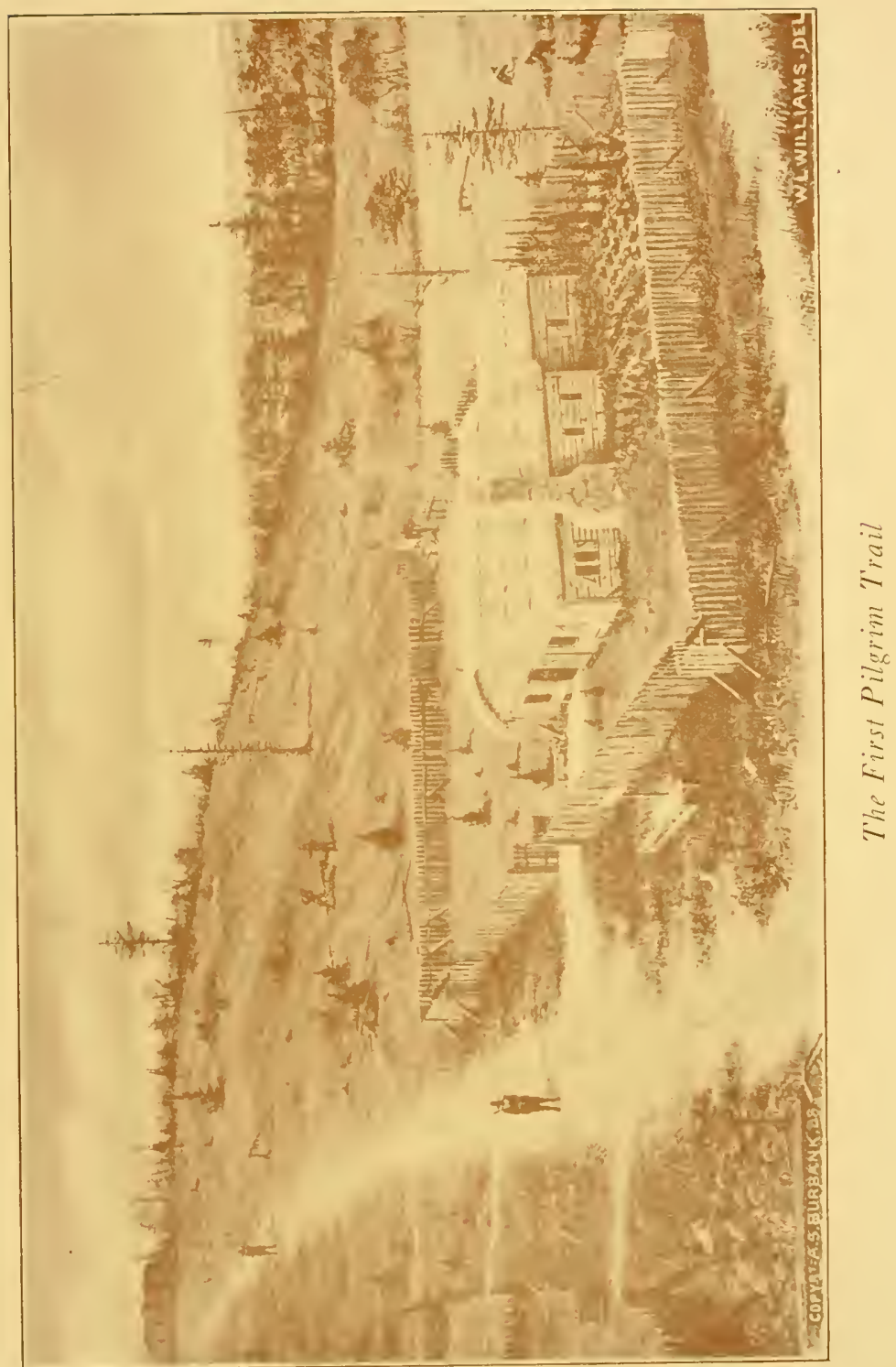



above your head sometimes and as big as a thumb end. These provide manna for all who will gather it, from late June till early September, when the checkerberries ripen, to hang on all winter. Others make the world better for their beauty and fragrance and of these the ground laurel, the trailing arbutus, the mayflower, is best known and loved.

It is easy to fancy some' sombre Pilgrim, weary with the woes of that first winter, his heart hungry for "the may" of English hedgerows, stepping forth some raw April morning which as yet showed no sign of opening spring buds, stopping as his feet rustled in brown oak leaves up Town Brook way, puzzled by the endearing, enticing fragrance on the wings of the raw wind. I always think of him as stopping for a moment to dream of home, looking about in a discouraged way for hawthorn which he knows is not there, then spying the little cluster of evergreen leaves with their pink and white blossons nestling among the oak leaves at his very feet and kneeling to pluck and sniff them in something like adoration. It may not have been that way at all, but someone found that first mayflower and loved and named it. 
The world at large, hurtling through Plymouth in its high-powered motor cars, stops along the road over Manomet and finds its arbutus there each May. I like to look for mine along the path that Billington took to his "sea," a way that leads out of Leyden street and up along Town Brook. I think the second oldest of the Plymouth land trails lies up that way. If the first was to and from the fort the second surely lay up along the brook, and I have an idea the Indians had preceded them in the making of this.

A great terminal moraine once blocked off Billington sea from the ocean, but Town Brook released it. Long before the Pilgrims came it had cut its valley through the great wall of gravel and occupied it in peace till latter day highways and factories came to vex it. In spite of these, unhampered bits of the original brook show in Plymouth itself and you are not far out of town before you see more of it.

It flows out of the "sea" unhindered now save by pickerel weed and sagittaria, rush and meadow grasses, and in woodsy places by brook alder, clethra, huckleberry and spice-bush that lean into it as they wrestle with greenbrier and clematis. The mayflower snuggles into the 


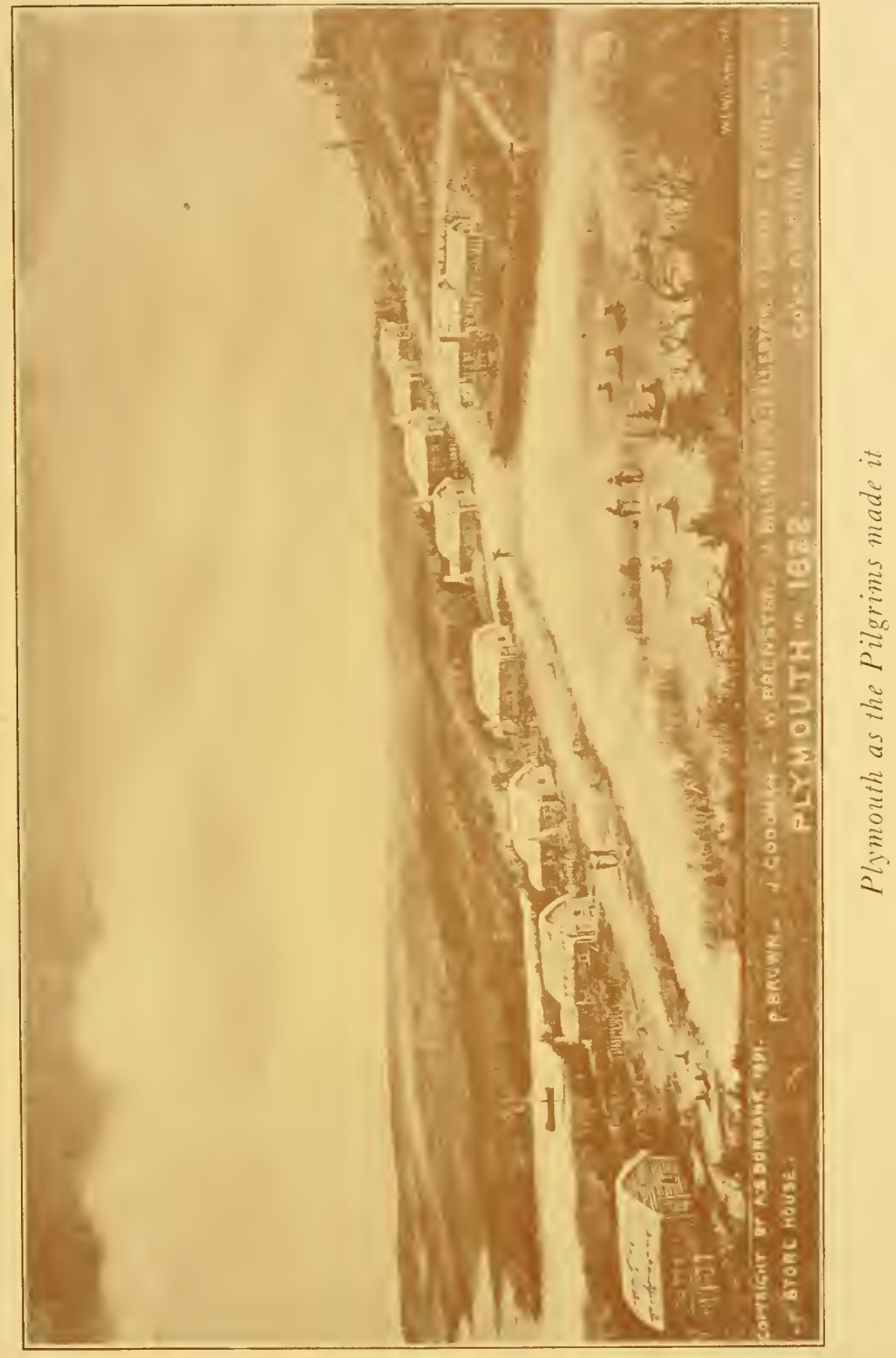



leaves along its drier upper margins, here and there, and is to be found on the borders of the "sea" more plentifully. Plymouth has done well in making of this region a park, beautifying it mainly by letting it alone, merely cutting new Pilgrim trails through it. Billington's path along the pond shore is thus made easy for your feet and is marked with his name that you may not miss it. But if you would see the real Billington path, made for him by generations of Indians before his day but the one that I believe he trod, you will look nearer the water's edge. There, tangled amidst undergrowth now, buried deep in brown autumn leaves, it is yet visible enough, cut into the soft sand of the pond bank. In places it is cut deep. In places it is all but obliterated or vanishes altogether for a little way, perhaps divides into two or three as the local needs of moccasined travellers called for, but all along the pond margin it goes. This is an old Plymouth trail indeed, linking the Plymouth of today with that of the time of the Pilgrims, and long before. There are many such that lead out of Plymouth, glimpsing for us the world of three hundred years ago mirrored in the eyes, the ideas, the ideals of today. Let us scarch them out. 


\section{CHAPTER II}

\section{PLYMOUTH MAYFLOWERS}

The first day on which one might hope for mayflowers came to Plymouth in late April. The day before a bitter northeaster had swept through the town, a gale like the December one in which the Pilgrim's shallop first weathered Manomet head and with broken mast limped in under the lee of Clark's Island. No promise of May had been in this wild storm that keened the dead on Burial Hill, yet this day that followed was to be better than a promise. It was May itself, come a few days ahead of the calendar, so changeful is April in Pilgrim land. This gale, ashamed of itself, ceased its outcry in the darkness of full night and the chill of a white frost followed on all the land.

In the darkest hour of this night, I saw a thin point of light rise out of the mystery of the sea far to the eastward, the tiny sail of the shallop of the old moon, blown landward by little winds of dawn, making port on the shore of "hither 
Manomet." In the velvety blackness of this ultimate hour of night the slender sail curved sweetly backward toward the sea, and the shallop seemed drawn to the land by a lodestone, as was the ship of Sindbad the Sailor, and when it magically climbed the dark headland and sailed away into the sky above, it drew out of the sea behind it the first light of glorious morning. From Manomet head to the Gurnet the horizon showed a level sea line of palest garnet that deepened, moment by moment, till the coming sun arched it with rose and bounded from it, a flattened globule of ruby fire. I like to think that the path of gold with which the sun glorified the stippled steel of the sea was the very one by which the first Mayflower came in from Provincetown, the sails nobly set and the ship pressing onward to that memorable anchorage within the protecting white arm of the sandspit.

I like to think that the sweet curve of the old moon's slender sail sways in by Manomet each month in loving remembrance of that other shallop that so magically won by the roar of the breakers on the dark point and brought the simple record of faith and courage for our loving remembrance. But whether these things are so 
or not I know that the very first rays of the morning sun pass in level neglect over the bay and the town to lay a wreath of light on the brow of Burial Hill and touch with celestial gold the simple granite shaft that stands over the grave of William Bradford, historian of Plymouth Colony and writer of the first American book. Such is the unfailing ceremony of sunrise in Plymouth, and such it has been since the first Pilgrim was laid to rest on the hill which lifts its head above the roofs and spires to the free winds of the world.

Plymouth is fortunate in this hill. It bears the very presence of its founders above the enterprise and ferment of a modern town which grows rapidly toward city conditions, a hill which is set upon a city and cannot be hid. Factories and city blocks and all the wonders of steam and electrical contrivance which would have astounded and amazed Bradford and his fellows are common in Plymouth today as they are common to all cities and towns of a vast country, yet the graves of the simple pioneers rise above them as the story of their lives transcends in interest that of all others that have come after them. The book that Bradford wrote, as the 
tales that Homer told, will last as long as books are read. Plymouth may pass, as Troy did, but the story of its heroes will remain. Bradford's book, which was our first, may well, at the end of time, be rated our greatest.

The trailing arbutus is peculiarly the flower of Plymouth. Not that it grows there alone, indeed within easy reach of the landing place of the Pilgrims it is not easy now to find it. Once, no doubt, it blossomed about the feet of the pioneers, sending up its fragrance to them as they trod sturdily along their first street and through their new found fields that first spring after their arrival. My, but their hearts must have been homesick for the English May they had left behind! and in memory of the pink and white of the hawthorn hedges they called this pink and white flower which peered from the oval-leaved vines trailed about their feet, mayflower. It surely must have grown on the slopes of Burial Hill, down toward Town Brook, but now one will look in vain for it there. I found my first blossom of the year by following the brook up to its headwaters in Billington Sea. The brook itself is greatly changed since Bradford's day. Its waters are now held back by dams where it winds 
through the sand hills and one mill after another sits by the side of the ponds thus formed. Yet the "sea" itself must be much the same in itself and its surroundings as it was in Billington's time. Nor do I wholly believe the legend which has it that Billington thought it was a sea in very truth. It is too obviously a pond to have deceived even this unsophisticated wanderer. It covers but little over three hundred acres including its islands and winding coves.

I think, rather, its name was given in good natured derision of Billington and his idea of the importance of his discovery, a form of quaint humor not unknown in the descendants to the Pilgrims of this day. Yet the waters of the little winding pond are as clear as those of the sea which breaks on the rocks of Manomet or the Gurnet, and the hilly shores, close set with deciduous growth, are almost as wild as they were then. The robins that greeted the dawn on Burial Hill sang here at midday, blackbirds chorused, and song sparrows sent forth their tinkling songs from the shrubby growths. Plymouth woods, here at least, are a monotony of oaks. Yet here and there in the low places a maple has 


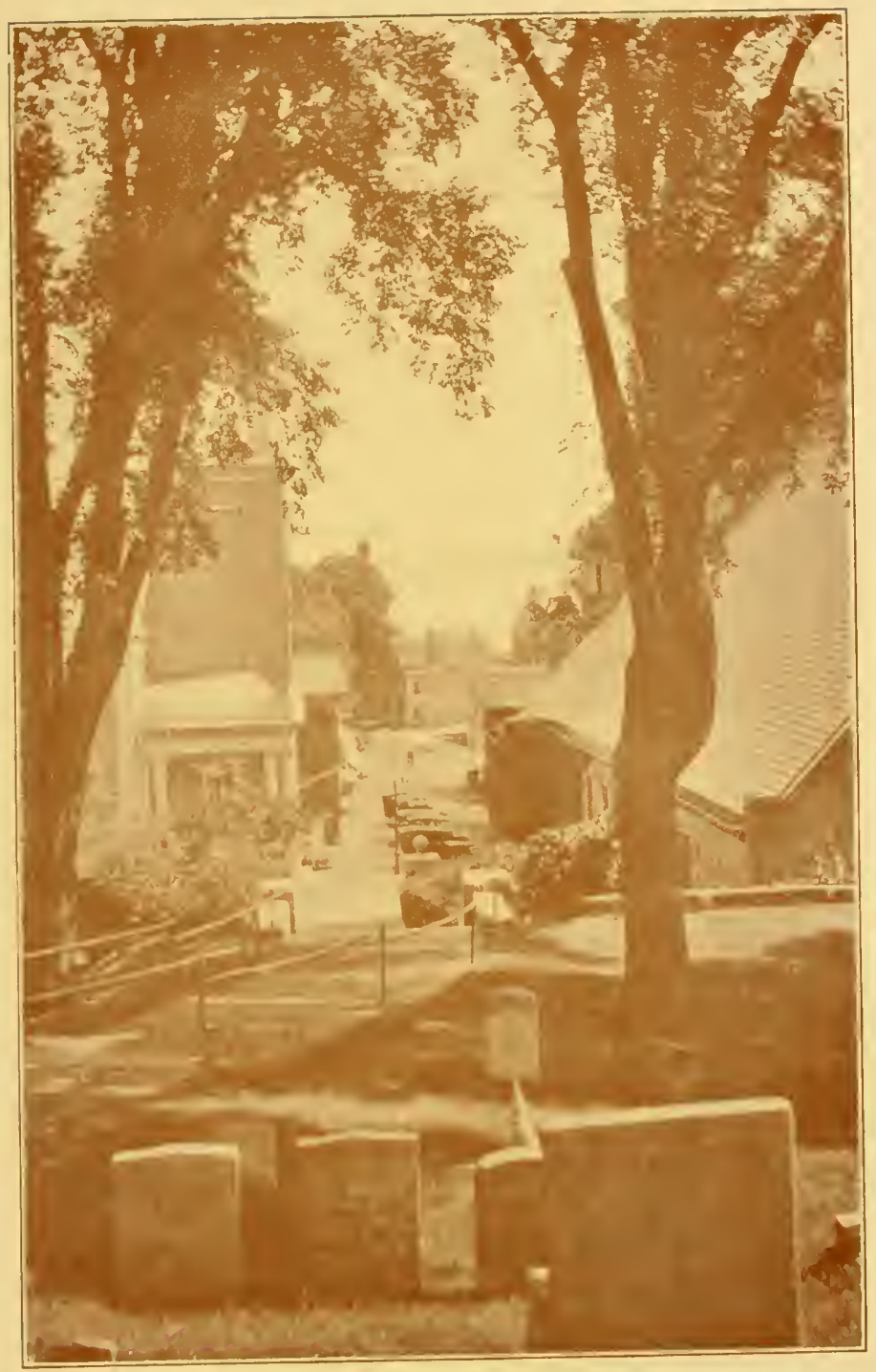

Levden Stree To-day from Burial II ill 

jecome a burning bush of ruby flame, and along the bog edges the willows are in the full glory of their yellow plumes. The richest massed coloring one can see in the region today, though, is that of the cranberry bogs. Looking away from the sun the thick-set vines are a level floor of rich maroon, not a level color but a background showing the brush marks of a master painter's hand. Toward the sun this color lightens and silvers to tiny jewel points where the light glances from glossy leaf tips. The later spring growth will fleck the bogs with greens, but the maroon background will still be there.

The arbutus does not trail in all spots beneath the oaks, even in this secluded wilderness. Sometimes one thinks he sees broad stretches green with its rounded leaves only to find last year's checkerberries grinning coral red at him, instead of the soft pink tints and spicy odor of the Epigra blooms. Sometimes the pyrola simulates it and cracks the gloss on its leaves with a wan wintergreen smile at the success of the deception. But after a little the eye learns to discriminate in winter greens and to know the outline of the arbutus leaf and its grouping from that of the others. Then success in the hunt 
should come rapidly. After all Epigæa and Gaultheria are vines closely allied, and it is no wonder that there is a family resemblance. The checkerberry's spicy flavor permeates leaves, stem and fruit. That of the arbutus seems more volatile and ethereal. It concentrates in the blossom and lifts from that to course the air invisibly an aromatic fragrance that the little winds of the woods sometimes carry far to those who love it, over hill and dale. Given a day of bright sun and slow moving soft air and one may easily hunt the Plymouth mayflower by scent. Even after the grouped leaves are surely sighted the flowers are still to be found. The winds of winter have strewn the ground deep with oak leaves and half buried the vines in them for safety from the cold. Out from among these the blossoms seem to peer shyly, like sweet little Pilgrim children, ready to draw back behind their mother's aprons if they do not like the appearance of the coming stranger. Perhaps they do withdraw at discretion, and this is very likely why some people who come from far to hunt find many mayflowers, while others get few or none.

Just as the Mayflower in which the Pilgrims sailed to Plymouth seems to have been but one 


\section{PLYMOUTH MAYFLOWERS}

of many English ships of that name, so the trailing arbutus is not the only flower to be called mayflower in New England. The mayflower of the English fields and hedgerows was preëminently the hawthorn, known often just as "the may." But there is a species of bitter cress in England with showy flowers, Cardamine pratensis, which is also called mayflower and the name is given to the yellow bloom of the marsh marigold, Caltha palustria, often known, less lovingly, as "blobs." The Caltha is common to both Europe and America and, though it is often hereabout known by the nickname of "cowslip" which the early English settlers seem to have given it, I do not hear it called mayflower. In localities where the arbutus is not common the name mayflower is here most commonly given to the pink and white Anemone nemorosa, the wind flower of the meadow margins and low woods, and to the rock saxifrage, Saxifraga virginiensis, both of which are amrong the earliest blossoms of the month.

None can visit Plymouth without wishing to climb the bold promontory of "hither Manomet." The legend has it that Eric the Red, the Viking who explored New England shores centuries be- 
fore the first Englishman heard of them, made this his burial hill and that somewhere beneath its forests his bones lie to this day. I sought long for mayflowers on the seaward slopes and in the rough gullies of these "highlands of Plymouth," I did not find them there.

On the landward slopes, gentler and less windswept, down toward the "sweet waters" that flow from inland to the sea, you may with patient search find many. But the heights shall reward you, if not with mayflowers with greater and more lasting joys. The woods of Manomet were full of butterflies. Splendid specimens of Vanessa antiopa danced together by twos and threes in every sunny glade, the gold edging of bright raiment showing beneath their "mourning cloaks" of rich seal brown. Here in the rich sunshine Launcelot might well have said:

Myself beheld three spirits, mad with joy, Come dashing down on a tall wayside flower.

Here Grapta interrogationis carried his ever present question mark from one dry leaf to another asking always that unanswerable "why?" Here Pyrameis huntera, well named the hunter's butterfly, flashed red through the woodland, 


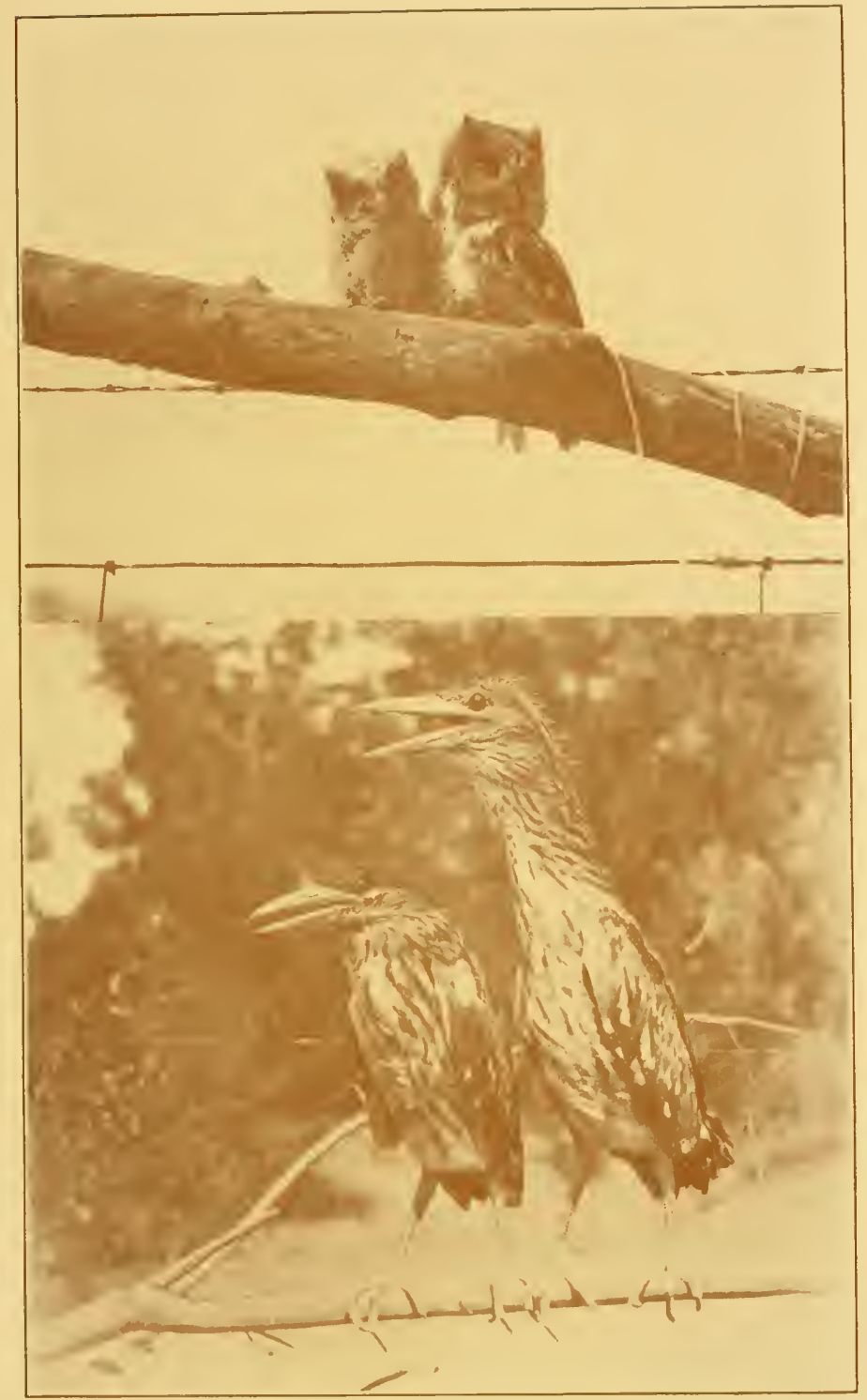

Birds of the Plymouth $/$ oods, $W$ ise and Otherwise 


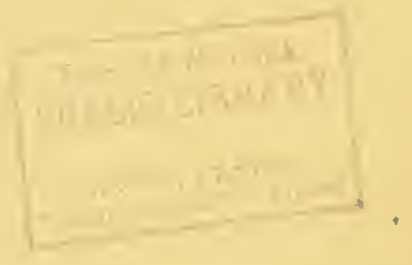


scouting silently and becoming invisible in ambush as a hunter should. Here a tiny fleck of sky, the spirit bluebird of the spring which the entomologists have woefully named Lycæma pseudargiolus, fluttered along the ground as if a new born flower tried quivering flight, and brown Hesperiidæ, "bedouins of the pathless air," buzzed in vanishing eccentricity. But it was not for these that I lingered long on the seaward crest. There below me lay the bay that the exploring Pilgrims entered at such hazard, that but the day before had been blotted out with a freezing storm and gray with snow, now smiling in unforgettable beauty at my feet, bringing irresistibly to mind the one who sang,

\section{My soul today is far away, \\ Sailing the blue Vesuvian bay.}

At Naples indeed could be no softer, fairer skies than this June day of late April brought to Plymouth Bay and spread over the waters that nestled within the curve of that splendid young moon of white sand that sweeps from Manomet to the tip of the sandspit, with the Gurnet far to the right and Plymouth's white houses rising in the middle distance. It lacked only the 
cone of Vesuvius smoking beyond to make the memory complete.

Nor has the Bay of Naples bluer waters than those that danced below me. Some stray current of the Gulf Stream must have curled about the tip of Cape Cod and spread its wonder bloom over them. Here were the same exquisite soft blues, shoaling into tender green, that I have seen among the Florida keys. Surely it was like a transformation scene. The day before the torn sea wild with wind and the dun clouds of a northeast gale hiding the distance with a mystery of dread, a wind that beat the forest with snow and chilled to the marrow; and this day the warmth of an Italian spring and the blue Vesuvian Bay.

The Pilgrims had their seasons of storm and stress, but there came to them too halcyon days like this when the mayflower bloomed in all the woodland about them, the mourning cloak butterflies danced with joy down the sunny glades, and the bay spread its wonderful blue beneath their feet in the delicious promise of June. Nor is it any wonder that in spite of hardships and disaster manifold they yet found heart to write home that it was a fayere lande and bountiful. 
But for all the lure of Plymouth woods with their fragrance of trailing arbutus, from all the grandeur of the wide outlook from Manomet Heights, the hearts of all who come to Plymouth must lead them back to the resting place of the fathers on the brow of the little hill in the midst of the town. There where the grass was not yet green and the buttercups that will later shine in gold have put forth but the tiniest beginnings of their fuzzy, three-parted leaves, I watched the sun sink, big and red in a golden mist, over a land of whose coming material greatness Bradford and his fellow Pilgrims could have had no inkling. Seaward the tropic bloom of the water was all gone, and there as the sun passed I saw the cool steel of the bay catch the last rays in little dimples of silver light. Manomet withdrew, blue and mysterious in the haze of nightfall. Out over the Gurnet, beyond, the sky caught purples from the colors in the west, and there, dropping below the horizon line, east northeast toward England, I saw a sail vanish in the soft haze as if it might be the first Mayflower, sailing away from the heavy-hearted Pilgrims, toward England and home. The sun's last ray touched it with a fleck of rose as it passed, a rose 


\section{OLD PLYMOUTH TRAILS}

like that which tipped the petals of the mayflowers that I held in my hand, mayflowers that sent up to me in the coolness of the gathering April night a fragrance as aromatic and beloved as is the memory of the lives of the Pilgrims that slept all about me on the brow of Burial Hill. Bradford wrote gravely and simply the chronicles of these, and no more, yet the fervent faith and sturdy love for fair play, unquenchable in the hearts of these men, breathes from every page, a fragrance that shall go forth on the winds of the world forevermore. 


\section{CHAPTER III}

UNBUILDING A BUILDING

I tore down an old house recently, rent it part from part with my own hands and a crowbar, piling it in its constituents, bricks with bricks, timber on timber, boards with boards.

Any of us who dare love the iconoclast would be one if we dared sufficiently, and in this work I surely was an image-breaker, for the old house was more than it seemed. To the careless passer, it was a gray, bald, doddering old structure that seemed trying to shrink into the ground, untenanted, unsightly, and forlorn. I know, having analyzed it, that it was an image of New England village life of the two centuries just gone, a life even the images of which are passing, never to return.

As I knocked the old place down, it seemed to grow up, more vivid as it passed from the roadside of the visible to the realm of the remembered. You may think you know a house by living in it, but you do not; you need to unbuild 
it to get more than a passing acquaintance. And to unbuild a building you need to be strong of limb, heavy of hand, and sure of eye, lest the structure upon which you have fallen fall upon you; nor do business mottoes count, for you besin not at the bottom, but at the top, or near it.

$\mathrm{Up}_{\mathrm{p}}$ in the attic among the cobwebs, stooping beneath the ancient rafters, dodging crumbly bunches of pennyroyal and hyssop, hung there by hands that have been dust these fifty years, you poise and swing a forty-pound crowbar with a strong uplift against the roof-board, near where one of the old-time hand-made, hammer-pointed, wrought-iron nails enters the oak timber. The board lifts an inch and snaps back into place. You hear a handful of the time-and-weatherworn shingles jump and go sputtering down the roof. You hear a stealthy rustling and scurrying all about you. Numerous tenants who pay no rent have heard eviction notice, for the house in which no men live is the abode of many races. Another blow near another nail, and more shingles jump and flee, and this time a clammy hand slaps your face. It is only the wing of a bat, fluttering in dismay from his crevice. Blow 
after blow you drive upon this board from beneath, till all the nails are loose, its shingle-fetters outside snap, and with a surge it rises, to fall grating down the roof, and land with a crash on the grass by the old door-stone.

The morning sun shines in at the opening, setting golden motes dancing, and caressing rafters that have not felt its touch for a hundred and fifty years, and you feel a little sob of sorrow swell in your heart, for the old house is dead, beyond hope of resurrection. With your crowbar you have knocked it in the head.

Other boards follow more easily, for now you may use a rafter for the fulcrum of your iron lever and pry where the long nails grip the oak too tenaciously, and it is not long before you have the roof unboarded. And here you may have a surprise and be taught a lesson in wariness which you will need if you would survive your unbuilding. The bare rafters, solid oak, six inches square, hewn from the tree, as adze-marks prove, are halved together at the top and pinned with an oak pin. At the lower end, where they stand upon the plates, they are not fastened, but rest simply on a $\mathrm{V}$-shaped cut, and when the last 
board is off they tumble over like a row of ninepins and you may be bowled out with them if you are not clever enough to foresee this.

As with the roof-boards, so with the floors and walls. Blows with the great bar, or its patient use as a lever, separate part from part, board from joist, and joist from timber, and do the work, and you learn much of the wislom and foolishness of the old-time builder as you go on. Here he dovetailed and pinned the framework so firmly and cleverly that nothing but human patience and ingenuity could ever get it apart; there he cut under the ends of splendid strong floor joists and dropped them into shallow mortises, so that but an inch or two of the wood really took the strain, and the joist seemed likely to split and drop out, of its own weight. You see the work of the man who knew his business and used only necessary nails, and those in the right places; and the work of that other, who was five times as good a carpenter because he used five times as many nails!

You learn, too, how the old house grew from a very humble beginning to an eleven-room structure that covered a surprising amount of ground, as one generation after another passed 
and one owner succeeded another. In this the counsel of the local historian helps you much, for he comes daily and sits by as you work, and daily tells you the story of the old place, usually beginning in the middle and working both ways; for the unbuilding of a building is a great promoter of sociability. Fellow townsmen whom you feel that you hardly know beyond a rather stiff bowing acquaintance hold up their horses and hail you jovially, even getting out to chat a while or lend a hand, each having opinions according to his lights. Strickland, whose prosperity lies in swine, sees but one use for the old timbers. "My!" he says, "what a hog-pen this would make!" Downes is divided in his mind between hen-houses and green-houses, and thinks there will be enough lumber and sashes for both. Lynde suspects that you are going to establish gypsy camps wholesale, while Estey, carpenter and builder, and wise in the working of wood, knows that you are lucky if the remains are good enough for fire-wood.

Little for these material aspects cares the historian, however, as he skips gayly from one past generation to another, waving his phantoms off the stage of memory with a sweep of his cane, 
and poking others on to make their bow to the man with the crowbar, who thus, piecing the narrative out with his own detective work in wood, rebuilds the story. It was but a little house which began with two rooms on the ground floor and two attic chambers, built for Stoddard who married the daughter of the pioneer landowner of the vicinity, and it nestled up within a stone's throw of the big house, sharing its prosperity and its history. No doubt the Stoddards were present at the funeral in the big house, when stern old Parson Dunbar stood above the deceased, in the presence of the assembled relatives, and said with Puritanical severity, "My friends, there lies the body, but the soul is in hell!"

The dead man had failed to attend the parson's sermons at the old First Congregational Church, near by, a church that with successive pastors has slipped from the Orthodoxy of Parson Dunbar to the most modern type of presentday Unitarianism.

A later dweller in the old house lives in local tradition as publishing on the bulletin board in the church vestibule his intention of marriage with a fair lady of the parish, as was the custom of the day. Another fair lady entering the 
church on Sunday morning pointed dramatically at the notice, saying to the sexton, "Take that notice down, and don't you dare to put it up again till I give the word."

The sexton, seeming to know who was in charge of things, took it down and it was not again posted for two years. The marriage then took place. A few years later the wife died, and after a brief period of mourning another notice was posted announcing the marriage of the widower and the lady who had forbidden the banns of his first marriage. The second marriage took place without interference, and they lived happily ever after, leaving posterity in doubt whether the incident in the church vestibule was the climax in a battle royal between the two ladies for the hand of the man who dwelt in the old house, or whether the man himself had loved not wisely but too many.

Another dweller in the old house was a locally celebrated singer who for years led the choir and the music in the old church, having one son whom a wealthy Bostonian educated abroad, "becoming," said the historian sagely, "a great tenor singer, but very little of a man." These were days of growing importance for the old house. 
Two new rooms were added to the ground-floorback by the simple expedient of tacking long spruce rafters to the roof, making a second roof over the old one, leaving the old roof with boards and shingles still on it. Thus there grew a roof above a roof, - a shapeless void of a dark attic, - and below, the two rooms.

The use of the spruce rafters and hemlock boarding marks a period in building little more than a half-century gone. About this time the house acquired a joint owner, for a local lawyer of considerable importance joined his fortunes and his house to it, bringing both with him. This section, two more rooms and an attic, was moved in from another part of the town and attached very gingerly, by one corner, to one corner. It was as if the lawyer had had doubts as to how the two houses might like each other, and had arranged things so that the bond might be broken with as small a fracture as possible. This "new" part may well have been a hundred years old at the time, for, whereas the original house was boarded with oak on oak, this was boarded with splendid clear pine on oak, marking the transition from the pioneer days when all the timber for a house was obtained from the neighbor- 
ing wood, through the time when the splendid pumpkin pines of the Maine forests were the commonest and cheapest sources of lumber, to our own, when even poor spruce and shaky hemlock are scarce and costly. In the same way you note in these three stages of building three types of nails. First is the crude nail hammered out by the local blacksmith, varying in size and shape, but always with a head formed by splitting the nail at the top and tending the parts to the right and left. These parts are sometimes quite long, and clinch back into the board like the top of a capital T. Then came a better nail of wrought iron, culmsy but effective; and, later still, the cut nail in sole use a generation ago. That modern abomination, the wire nail, appears only in repairs.

Thus the old house rose from four rooms to eight, with several attics, and the singer and lawyers pass off the scene, to be followed by the Baptist deacon who later seceded and became a Millerite, holding meetings of great fervor in the front room, where one wall used to be covered with figures which proved beyond a doubt that the end of the world was at hand, and where later he and his fellow believers appeared in their 
ascension robes. He too added a wing to the old house, three rooms and another attic, and when I had laid bare the timbers of this the historian rose, holding both hands and his cane towards heaven, and orated fluently.

"There!" he said, "that's Wheeler! I knew it was, for the old deeds couldn't be read in any other way. They told me it was built on by the Millerite, but I knew better. This was moved up from the Wheeler farm, and it was a hundred years old and more when it came up, sixty years ago. I knew it. Look at those old cap-posts!"

I doged the cane as it waved, and took another look, for it was worth while. There were the corner posts, only seven feet high, but ten inches square at the bottom, solid oak, swelling to fourteen inches at the top, with double tenants on which sat the great square oak-plates, dovetailed and pinned together, and pinned again to the cap. A hundred and fifty years old and more was this addition, which the Millerite had moved up from the Wheeler farm and built on for his boot-shop; yet these great oak cap-posts marked a period far more remote. They were second-hand when they went into the Wheeler building, for there were in them the marks of mortising that had no 
reference to the present structure. Some building, old a century and a half ago, had been torn down and its timbers used for the part that "had been Wheeler."

Thus the old house grew again as it fell, and the old-time owners and inhabitants stepped forth into life once more. Yet I found traces of other tenants that paid neither rent nor taxes, yet occupied apartments that to them were commodious and comfortable. In the attic were the bats, but not they alone. Snuggled up against the chimney in the southern angle, right under the ridge-pole, was a whole colony of squashbugs which had wintered safely there and were only waiting for the farmer's squash vines to become properly succulent. A bluebottle fly slipped out of a crevice and buzzed in the sun by the attic window. Under every ridge-board and cornerboard, almost under every shingle, were the cocoons and chrysalids of insects, thousands of silent lives waiting but the touch of the summer sun to make them vocal.

On the ground floor, within walls, were the apartments of the rats, their empty larders choked with corn-cobs showing where once had been feasting, their bed chambers curiously up- 
holstered with rags laboriously dragged in to senseless confusion. The field mice had the floor above. Here and there on the plates, between joists, and over every window and door, were their nests, carefully made of wool, chewed from old garments and made fine, soft, and cosy. Their larders were full of cherry-stones, literally bushels on bushels of them, each with a little round hole gnawed in it and the kernel extracted. As the toil of the human inhabitants year after year had left its mark on the floors of the house, worn thin everywhere, in places worn through with the passing and repassing of busy feet, so had the generations of field mice left behind them mute witnesses of patient, enormous labor. From the two cherry trees in the neighboring yard how many miles had these shy little people traveled, unseen of men, with one cherry at a time, to lay in this enormous supply!

Within the chimneys were the wooden nests of chimney swifts, glued firmly to the bricks; under the cornice was the paper home of a community of yellow hornets; and under the floor where was no cellar, right next the base of the warm chimney, were apartments that had been occupied by generations of skunks. Each space between floor 
joists and timber was a room. In one was a huge clean nest of dried grass, much like that which red squirrels build of cedar bark. Another space had been the larder, for it was full of dry bones and feathers; others were for other uses, all showing plainly the careful housekeeping of the family in the basement.

I looked long and carefully, as the work of destruction went on, for the pot of gold beneath the floor, or the secret hoard which fancy assigns to all old houses; but not even a stray penny turned up. Yet I got several souvenirs. One of these is a nail in my foot whereby I shall remember my iconoclasm for some time. Another is a curiously wrought wooden scoop, a sort of butterworker, the historian tells me, carved, seemingly, with a jackknife from a pine plank. A third is a quaint, lumbering, heavy, hand-wrought fireshovel which appeared somewhat curiously. Reentering a room which I had cleared of everything movable, I found it standing against the door-jamb. Fire-shovels have no legs, so I suppose it was brought in. However, none of the neighbors has confessed, and I am content to think it belonged in the old house and was brought back, perhaps by the Baptist deacon who 
"backslided" and became a Millerite. It has been rusted by water and burned by fire, and I don't believe even Sherlock Holmes could make a wiser deduction.

As I write, a section of one of the old "Wheeler" cap-posts is crumbling to ashes in my fireplace. It was of solid oak, of a texture as firm and grainless almost as soapstone. No water had touched this wood, I know, for a hundred and fifty years, perhaps for almost a hundred added to that. For hours it retained its shape, glowing like a huge block of anthracite, and sending forth a heat as great but infinitely more kindly and comforting. Toward the last the flames which came from it lost their yellow opaqueness and slipped fluttering upward in a transparent opalescence which I never before saw in fire. It was as if the soul of the old house, made out of all that was beautiful and kindly in the hopes and longings of those who built it and lived in it, stood revealed a monument in its shining beauty before it passed on. 


\section{CHAPTER IV}

FOREFATHERS' DAY

One does not need to seek the brow of Cole's Hill very early on Forefathers' Day to see the star of morning rise and shine upon Plymouth. It marks the passing of one of the four longest nights of the year, those of the four days before Christmas, a memorable period for all Americans, for during it the Pilgrim Fathers came to Plymouth. According to the best authorities the exploring party set foot on the famous rock on Monday, Dec. 2I (new style). But the ship herself did not enter the harbor for five days. Friday, the I8th, the explorers reached Clark's Island after dark and spent the night most miserably, though it was next door to a miracle that they got there alive and no doubt they were thankful for that. How they battled by Manomet Point in the half gale and high sea, the night already upon them and the harbor unknown to any aboard, their rudder gone and their mast "broken in three places," we know from Brad- 
ford's graphic description. On Saturday they rested on their island and dried their clothes and their gunpowder. On Sunday they prayed and otherwise kept the Sabbath as was their want. On Monday they went ashore on the mainland, found the situation desirable, and struck boldly across the bay to the Mayflower inside the hook of the Cape, to tell the news.

So the first of the Forefathers set foot on Plymouth soil on the 2 Ist of December, according to the revised calendar. But the Mayflower herself did not enter the harbor till five days later.

"On the I5th of December," says Bradford (on the $25^{\text {th }}$ as we now reckon it, though ten days before the England they had left behind would celebrate Christmas), "they weighed anchor to go to the place they had discovered, and came 'within two leagues of it, but were fain to bear up again, but the I6th day the wind became fair and they arrived safely in the harbor and afterward took a better view of the place and resolved where to pitch their dwellings and the $25^{\text {th }}$ day began to erect the first house for common use, to receive them and their goods.

Forefathers' Day is rightly set, then, on the 
2Ist, though we have really an all-winter landing of the Pilgrims, the ship remaining in the harbor and being more or less their refuge until the $5^{\text {th }}$ of April, I62I. In some respects the place of their landing has vastly changed. The waterfront is ugly with rough wharves and coal pockets, store-houses and factories. The famous rock itself reposes beneath a monstrous granite canopy and seems to have so little connection with the sea that one at first sight is inclined to levity, wondering where the landing party got the gang plank which bridged such a distance. Yet it was in all reverence that I sought Plymouth, hoping to in some measure bridge the three centuries that lie between that day and this, and see the New World in some measure as they saw it, at the same season.

For at least the seasons have not changed. The storms and the calms, the snow and the sunshine, come now, as then, in cycles that may not match day by day in all instances, but, taking year by year, come surprisingly near it. There is more in the Old Farmer's Almanack's serene forecast of the weather for an entire year ahead than most of us are willing to admit. There are people who back its oracle against the Weather 
Bureau and claim that they travel warmer and drier by so doing. Yet if one makes a study of - Farmers' Almanack weather he finds that it wins by predicting the same storms and the same cold snaps, the same drought and the same rain for just about the same seasons, year after year, spreading the prophecy over days enough to give it considerable leeway. "About this time expect a storm," it says, and in the ten days of the aforesaid time the storm is pretty apt to come.

So, to my joy, I found in Plymouth on my few days there on Forefathers' Day week just about the weather Bradford reports for that first voyage of the Mayflower's shallop to its harbor. "After some hour's sailing," says Bradford, "it began to snow and rain, and about the middle of the afternoon the wind increased and the sea became very rough and they broke their rudder and it was as much as two men could do to steer her with a couple of oars. But their pilot bade them be of good cheer as he saw the harbor, but the storm increased and night coming on they bore what sail they could to get in while they could see. But herewith they broke their mast in three pieces and their sail fell overboard in a very grown sea, so that they were like to have been cast away." 


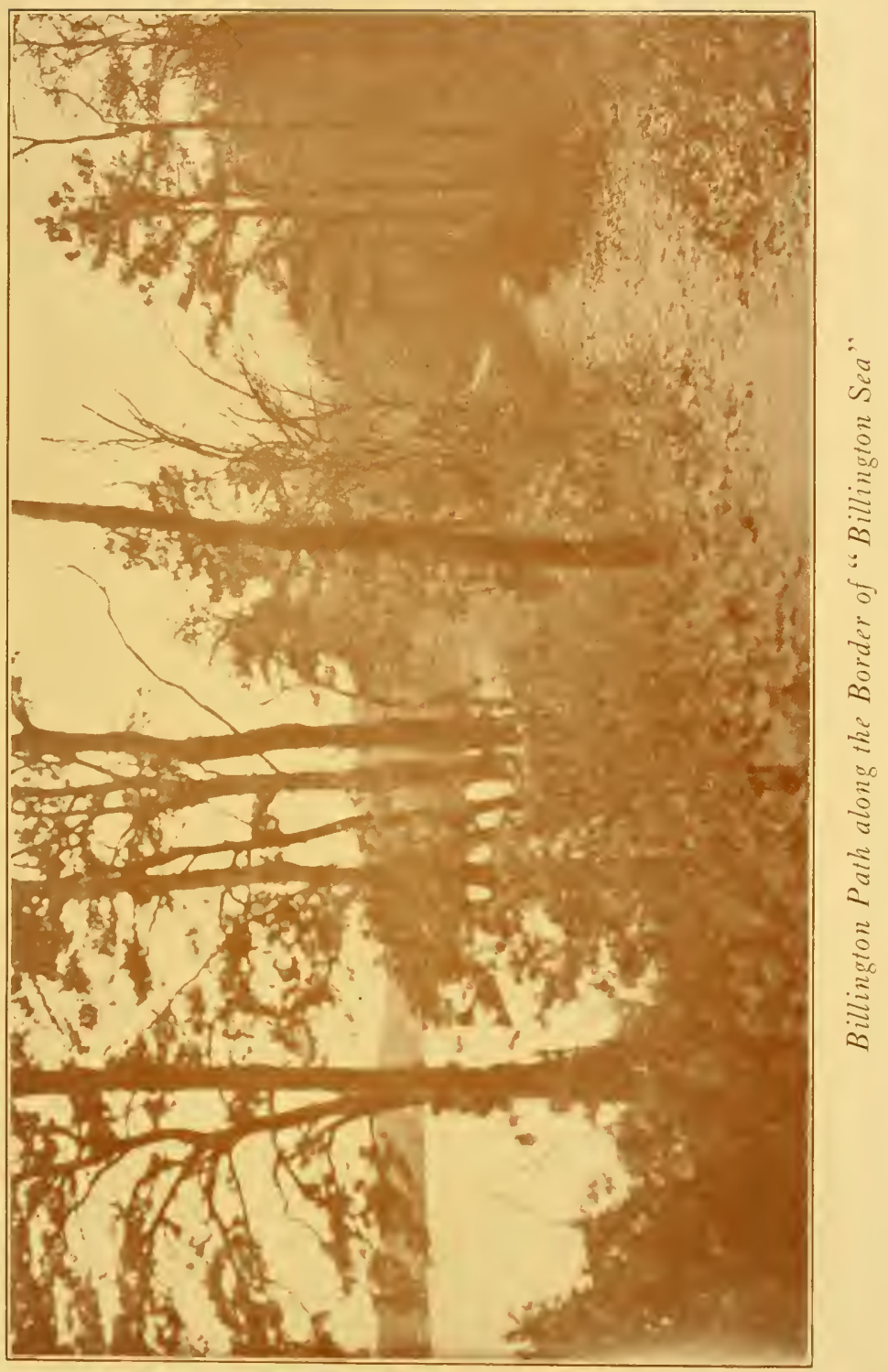



Anyone who knows that Massachusetts coast in December will recognize the weather, a wind from the northeast bringing mingled rain and snow, not a gale, but a squally wind, with a "very grown sea" such as beat upon the coast at the beginning of this week, sending the white horses racing up the beach below Manomet Head, which has been named for them, and smashing in continuous thunder on the stern and rockbound cliffs between White Horse Beach and Plymouth harbor.

To see Manomet in stormy December is to know how grim it is. The wooded headland which the little shallop so desperately won by in the gloom of that December twilight and storm has changed little if any since that time. Stern and rock-bound it certainly is. The sea of centuries has beaten against the great drumlins of boulder-till and has not moved the boulders that bind them together. At the most it has but washed out the smaller ones, leaving the sea front surfaced with great white granite rocks that gleam like marble in the sundown to the limits of the washing tide, then shine olive green with the froth of the waves. From the sands of White Horse Beach to those of the Spit in Plymouth 
harbor there is no place where that storm-tossed shallop might have made a landing with any hope of safety. To have turned toward the shore as the pilot bade them when the mast broke would have been to drown the whole company in the surf, in which case Plymouth would never have been. No one knows the name of the "lustie seaman" who then usurped the command and bade the rowers "if they were men, about with her, or else they were all cast away." On the words of this courageous unknown hung the lives of the company and perhaps the fate of the expedition itself. It is a stern and rock-bound coast in very truth, and if it seemed as dark and forbidding on that December nightfall in 1620 as it did on one of the same date this year, I for one would not have blamed them had they sailed away, never to come back. For a quarter of a mile off shore scattered boulders curried the surf and fluffed it into white foam. Its deafening roar was filled with menace. Salt spray and sleet mingled cut one's face rods back from the shore, and high up the dark hill behind rose the gnarled woodland, wailing and tossing its giant branches. With the fall of night no light was visible from sea or shore. All was as primal, as chaotic, as 


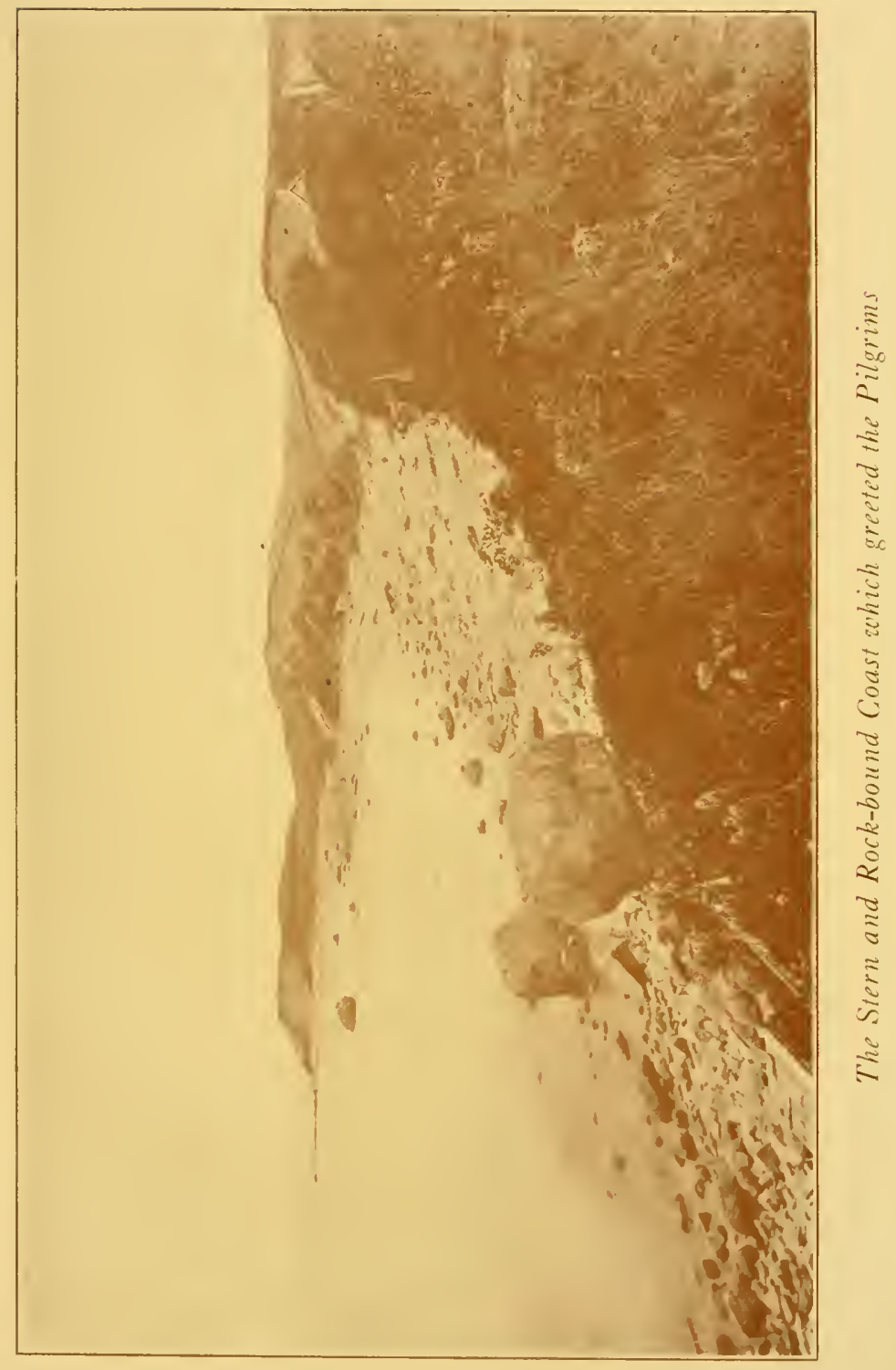




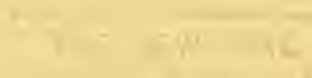

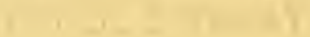

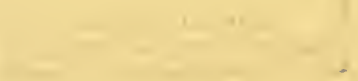


menacing as it had been on that Friday night three centuries before when the Pilgrims' shallop beat in by the point, its tiny white sail drowned like the wing of a seagull in the dusky welter of the sea.

That night, as on the night that the Pilgrims came, the wind changed to the westward and blew the storm to sea. Yet all night from Cole's Hill I saw the dark clouds to seaward, lingering there and refusing to be driven completely away, and in the gray of dawn the morning star rose out of them, overmatching with its clear light that of the Gurnet which shone from the murk of their depths below. The frozen ground rang beneath the heel and the cold had bitten deep. Out of the northwest a few flakes of snow came and it was long before the sun shone through the clouds and touched the top of Manomet Hill. Yet when it did it came with a burst of golden glory and filled the sky with such rosy and benign colors that one half expected to see a flight of Raphael's cherubs through it to earth. And all the land beneath was softened with a blue haze from east to south, making of it a country of romance through which pricked towers of Aladdin 
palaces and in which one knew at sight that he might find all his dearest dreams coming true. Thus the Pilgrims saw it that first morning from Clark's Island and the sight must have warmed the hearts of them and dried the tears out as it dried the garments wet with salt spray and cold rain.

The wind from the west was keen for the next few days, but it blew all the forebodings out of the sky and to find the south side of a hill or even a thicket was to find perfect comfort. The sea off Manomet was no longer chaotic and menacing, but was stippled with dancing light on a soft, rich blue that was as soothing to the sense as the other had been disquieting. Along the south of White Horse Beach the lapidary surf had strewn quartz pebbles that gleamed in the clear sun like precious stones. It took little effort of the imagination to find pocketfuls of rubies, pearls, sapphires, and amethysts among these, and had it indeed been "bright jewels of the mine" which the voyagers sought they might have been pardoned for thinking they had found them there. And all ashore under this alluring blue haze lay a country that was superlatively lovely even under frozen skies and on the shortest day of the year. 
Southerly toward it the shallop sailed in I620, under flocks of whirling white gulls, through flocks of black and white Labrador ducks that then wintered in numbers along our shores, from Clark's Island to the mouth of Town Brook.

Factories and dwellings line Town Brook, now in place of the primeval forests of pine and oak. Its waters leap one dam after another, but cannot escape pollution till their dark tide mingles with that of the clear sea. But for all that the contour of the chasms in the big sand hills through which it flows to the sea is changed but little. The low sun leaves it in shadow most of the day and one can fancy the Pilgrim children and perhaps their elders glancing often up its shadowy cañon under black growth, a mysterious gulch down which at any time might stride the savages they so feared, or other, worse terrors of the unknown wilderness. The little knowledge of their day was but a tiny oasis in the vast desert of unknown things, and in that country to the south and west that was so alluring under the golden glow of the sun through its soft blue haze might dwell both gorgons and chimeras dire. For though the children were not with the explorers when they landed from the shallop on 


\section{OLD PLYMOUTH TRAILS}

Forefathers' Day, they came five days later in the Mayflower itself.

There were twenty-eight of these children, varying in age from the babe in arms to wellgrown, lusty youths and maidens. Christmas was at hand, and one fancies that all knew much about it, and spoke little, perhaps not at all. So far as record goes they had broken absolutely from all that they believed the follies of the fatherland. Yet in the hearts of many, one can but think, must have remained warm memories of Yule logs, of the boar's head, piping hot and decked out with holly berries, and of the lowceiled, oak-wainscotted dining halls of Old World houses all alight with candles and green with Christmas decorations. It is a pity that in repudiating the folly they had to repudiate also the fun. For just ashore in this land of mystery to which they had come were opportunities for Christmas greenery and Christmas feasting which they would have done well to take. The English holly they had left behind, yet along Town Brook grew the black alder with its red berries that are so pretty a substitute for the others, a holly itself, or at least an Ilex. All about Plymouth in the low grounds may be found these 
cheery, bright red berries, even over on the seaward slope of Manomet Head I found them, snuggling in hollows where tiny rivulets trickle down to the sea, though on the ridge above them the oaks were dwarfed and storm-beaten till one has difficulty in recognizing them for the variety of tree that they are.

It is easy to believe that down to the very rock on which they landed crept the club-moss which the descendants of the Pilgrims so soon learned to call "evergreen." Tons of it we use today in our Christmas decorations, nor does the supply from the Massachusetts woods seem to diminish, ground-pine, common, and "coral" evergreen, all varieties of the club-moss, that are commonest out of the dozen that we have in all. Just up those dark gullies Town Brook would have led them, as it will lead anyone today, to a country that now, as it was then, is rich in winter beauties of the woodland with which the exiles might well have decorated the cabin of the Mayflower. And just within the woods in any direction waited for them, had they had the will and the wisdom to seek them, all kinds of Christmas cheer. Deer were there, wild turkeys in great flocks and two varieties of grouse as tame as 
chickens on a farm, and more delicious than any Christmas goose which might have been served them in Holland or England. There were no savages about Plymouth at the time and they might have travelled the woods boldly, instead of taking prudent council of their fears. But they need not have gone so far as that for their Christmas feast. The sandy flats of nearby creeks were full of clams and the sea of fish. The boar's head they might not have, but there were splendid substitutes for it if they had cared to make their Christmas feast of products of the new land to which they had come.

Against all this, no doubt, they sternly set their faces, and indeed, instead of feasting and good cheer on their December $25^{\text {th, they set }}$ soberly to work to build their first common house, cutting greenery indeed, but not for decoration, and dining abstemiously on the stores that they had shipped months before in England. One can but believe that had they for a few bright holidays put their fears behind them with their solemnity and celebrated their own safe landing with a few roasted turkeys, a few boiled cod and some clam soup, eaten in an evergreen-decorated cabin of their good ship, or about a barbecue 
fire on shore, they might have taken a step toward warding off the sickness which was even then fastening itself upon them. But they certainly did not, and in visiting their landing-place on their landing-day and trying to see the world here as they then saw it, one must put such riotous thoughts out of mind, as he must put the great present-day town out of it.

Those two things aside on any before-Christmas week it is possible to see the landing-place of the Pilgrims much as they saw it, to feel the same stormy weather sweep across the same sea and to see landward the same hills clad with dark forests tossing their giant branches and seeming to hold much of mystery and dread. To know just a little of what they saw and felt one need but to stand on the brow of Manomet Head when a December night lowers and the northeast wind is hurling the surf on the rocks out of "a very grown sea." 


\section{CHAPTER V}

\section{THE SINGING PINES}

The pines were asleep in the noonday heat That shimmered down the lea, But they waked with the roar of a wave-swept shore When the wind came in from the sea.

They sang of ships, and the bosun piped,

The hoarse watch roared a tune, The taut sheets whined in the twanging wind, You heard the breakers croon.

For their brothers, masts on a thousand keels, Had sent a greeting free, And the answering song swelled clear and strong

When the wind came in from the sea.

Last night $\mathrm{I}$ heard the pines sing again. A winter midnight was on the woods, while a northeaster smote the coast, a dozen miles away, with the million sledges of the surf. So mighty was the story of this smiting, that for long I thought the pines sang of nothing else. In places and at times they told it with astonishing fidelity. A forty-mile gale muttered and grumbled to itself 
high in air above. Its voice was that of the gale anywhere when unobstructed. You may hear it at sea or ashore, a hubbub of tones indistinguishable as gust shoulders against gust and grumbles about it. In the quiet at the bottom of the wood I could hear this, too, especially at times when the wind lifted above the pine tops, leaving them in hushed expectancy of the story to come, a telling oratorical pause. For a little the voice of the gale itself would come burbling down into the momentary stillness, then with a gasp at the awesomeness of the tale the pines would take up the story again. In it there was none of the dainty romance the boughs will weave for the listener who cares to know their language of a sunny summer afternoon, little stories of tropic seas, of nodding sails and of flying fish that spring from the foam beneath the forefoot and skim the purple waves. This song was an epic of the agelong battle between the sea and the shore, a song without words, but told so well in tone that it was easy, seeing nothing there in the black shadow of the wood, yet to see it all; the jagged horizon against the sullen sky, the streaks of mottled foam sliding landward along the weltering backs of black waves, spinning into sea drift 


\section{4

at every wind-sheared crest, and blowing, soft as wool, in rolling masses far inland. It was easy to see the greatest crests rear and draw back, showing the roots of the ledges among boulders brown with weed and sea wrack, then swing forward with seemingly irresistible might, to be shattered as if their crystal was that of glass and to fly skyward a hundred feet, scintillant white star drift of comminuted sea. The crash of such waves on such rocks, the hollow diapason of their like on sands, and the shrill roar of a pebbly beach torn and tossed by the waves, all sprang from nothingness into vibrant being there in the black woods as the gale shouldered by the pine tops.

There is a point where the pines group on the pond shore and look expectantly east, wistful of the sea. Here they caught the full force of the gale and sang mightily, a wild, deep-toned, marching symphony of crashing forces. Now and then a lull came, as comes in the fiercest gales, and in the vast silence which ensued I heard the pines across the pond singing antiphonally. Black as it was under the trees, there was a moon behind the night. No suggestion of it showed through the clouds, yet from the pond 
surface itself came a weird twilight, filtered no doubt through a mile of flying scud a mile above, reflected from the wind-swept surface and showing these distant pines lifting heads of murk against the murky sky. But their antiphonal shout was no pine-voiced song of the sea, it was the sea itself. Again and again I listened in successive lulls. I could not believe it the pines. I heard so surely the rush of waves, the deep boom of beating surges, all the mingled clangor of the on-shore gale, that I thought through some atmospheric trick I was listening to the thing itself; the uproar swept over the hills a dozen miles inland. Only by marching up the pond shore until the pines across were south instead of east of me did I prove to myself that it was they and not the sea in very truth that I heard.

Back again in the Stygian darkness of the grove it was easy to note how the pines protect their own. On the beach the smothering onrush of the gale beat me down, drove me before it. Yet I had but to walk inland a dozen yards to find a calm. The outermost trees shunted the gale and half the time it did not touch even the tops of those a hundred feet in. Walking out into the midnight storm, I had wondered how it 
fared with the small folk of the forest. So fierce was the onslaught of the wind that it seemed as if the birds might be blown from their roosts, the squirrels shaken from their nests. Under the shelter of the trees themselves I knew they were as safe as I from any harm from the wind. There was not enough of it below the tree-tops to ruffle a feather.

To lay one's ear closely and firmly against the trunk of one of these pines was to curiously get an inkling of what was going on far up among the branches. It is quite like listening at a telephone receiver, the wood like the wire bringing to the ear sound of many things going on within touch of it. Thus placed, I was conscious that the seemingly immobile tree swayed rhythmically, just the very slightest swaying in the world, and this I seemed to hear. It was as if the slight readjustment of the woody fibre gave me a faint thrumming sound, a tiny music of motion that was a delight to the ear after the beat and bellow of the gale beyond.

Twigs rapped one upon another, making little crisp sounds. Most surprising of all, however, was a tinkling tattoo of musical notes as if a dryad within were tapping out woodland mel- 
odies on a xylophone. I listened long to this. It was not exactly a comfortable position. To hear I must press, and the tree bark was hard and the rain ran down the trunk and into my ear. Yet the music was exquisite, a little runic rhyme, repeated over and over again with quaint variations but with neither beginning nor end. It was wonderfully wild and fairylike. Who would stop for water in his ear or a pain in the lobe of it? Midnight, the middle of the gale, the middle of the woods; perhaps here was that very opening into the realm of the unseen woodland folk that we all in our inmost hearts hope for and expect some day to find.

So did he feel who pulled the boughs aside, That we might look into the forest wide.

Telling us how fair trembling Syrinx fled Arcadian Pan, with such a fearful dread. Poor nymph-poor Pan-how he did weep to find Naught but a lovely sighing of the wind Along the reedy stream; a half heard strain, Full of sweet desolation, balmy pain.

It may have been the dryad, playing the xylophone for a dance unseen by my gross mortal eyes, but if my water-logged ear did not deceive 
me-and I hope it did-it was only the beat of the big drops of rain on the twigs above, clarified and made resonant by its passage through the vibrant wood to my ear. At any rate, it was a most delightful musical entertainment of which I fancy myself the discoverer, and I hope it was the dryad. He who reads may believe as he will.

Beyond the pines I found the wind in the woods. Among the bare limbs of the deciduous growth the storm wailed and clattered its way on about my head as I felt out the path with my feet for a half mile to a pine-crowned hilltop. Again I was in sanctuary. The hilltop carried us up-the pines and me-into the full sweep of the gale, yet under their spreading, beneficent arms I felt no breath of wind. Overhead I noted its own wild voice as, very near and right with it in chorus, the pines sang, swaying in time to their music as I have seen a rapt singer do. Strangely enough, in their tones up here I could hear no cry of the sea. They sang instead the tumult of the sky, the vast lonliness of distant spaces, something of the deep-toned threnody of the ancient universe, mourning for worlds now dark.

Something of this the gale drew from the pines 
as it crowded by, but never once did its fiercest gusts disturb the serenity of the sanctuary beneath. A foot or two down from their topmost boughs was shelter for the crows, snugged down on a lee limb, close to the trunk, their feathers set to shed such rain as might strike them, their long black beaks thrust beneath their wings, rocked in the cradle of the deep woods, sung to sleep by their lullaby of the primal universe. There was little need to waste sympathy on them or on any other little folk of the forest who had for their shelter the brooding arms of these beneficent trees stretched above them.

Pines are the great, deep-breasted mothers of the woods, giving food and shelter from sun and storm to all who will come to them. Prolific mothers they are, too, and if man with his axe and his fire would but spare them they would in a generation or two reclothe our Massachusetts waste lands with their kind once more. Recklessly as the generations have destroyed them, sweeping often great tracts bare of every noble trunk, leaving the slash piled high for the fire to complete the destruction of the axe, they still persist, pushing the greenwood with its fluffy plumes right to our dooryards. Let the ploughed 
field lie fallow for a decade and see them come, loyal little folk preparing the way for them, as the trolls of ancient tales worked for those they loved. Into the brown furrows troop the goldenrod and asters, the wild grasses and brambles making a first shelter for the seeds of gray birch and wild cherry that magically come and plant themselves. A thousand other forms of life, beast and bird and insect, make the place their home, all preparing it for the nursing. of the young pines to come. However rough has been the work of the wood cutters, however persistent the forest fires, somewhere is a seed pine standing, ready to spear the turf a mile away with brown javelins out of whose wounds shall spring trees, just as out of the Cadmus-sown dragon's teeth of old sprang armed men. The tree may be a century-old gnarled trunk, too crooked and knotty to be worthy the woodman's axe, or a verdant sprout of a score of years' standing, green and lusty - the result will be the same. When the seeding year comes the brown cones will open and the winds will bear the germs of the new growth forth, spinning down the gale, whichever way they list to blow. The tiny pines that result may live for three or four years amongst the 
brambles unnoticed, then suddenly they take heart and grow and we find a lusty forest coming along. At three years they will not be over ten inches high, but they will make ten inches in height the next year, and after the fifth they stride forward like lusty youths, glorifying in their increase. It is not uncommon for them to stretch up three feet a year, more than doubling their height in that sixth year in which they strike their stride. They do not cease this upward striving as long as they live.

After the age of sixty or so the pine may be said to have passed the heyday of its youth, no longer increasing so rapidly in height and girth, yet the increase goes on, if more sedately. The tree rarely reaches a height of more than $\mathrm{i} 60$ feet and a diameter of more than forty inches. The largest ever measured by the Forestry Department of the United States was forty-eight inches in diameter at breast high and $\mathrm{r} 70$ feet in height, containing 738 cubic feet of wood in its mighty trunk. It will be some time before seedlings in the bramble patch here in Massachusetts reach that size, however, for this tree was 460 years old. It grew among trees of similar age in a pine forest in Michigan. 
Yet New England pines have matched it, and more. Writing in 1846 , Emerson tells of trees here 250 feet in height and six feet in diameter. One in Lancaster, New Hampshire, measured 264 feet. Fifty years before that trees in Blandford measured when they were felled 223 feet in length. The upper waters of the Penobscot were long the home of mighty pine trees where it was no uncommon thing to hew masts 70 to 90 feet in length. In I84I one was hewed there 90 feet in length, 36 inches in diameter at the butt and 28 inches at the top. Such trees have passed, now, almost from the memory of living man. Could we have them here in our State they would be worshipped as were the druidical trees of ancient European countries and the place of their standing would be made a park that they might be visited by all, rich or poor. It seems a pity that our ancestors could not have thought of this. It would have been so easy for them to let clumps of these wonderful old pines stand, here and there. It is so impossible for us to bring one of them back, with all our wealth and all our learning.

If we may believe the geologists the pines were the original tree inhabitants of our land, massing 
it in their dark green from mountain top to sea shore. Suddenly no one knows whence, the oaks and other deciduous trees appeared among them and in part drove them out of the richer soils. "The oak," says Gray, "has driven the pine to the sands." Yet the pines grow equally well among the rough rocks of mountain slopes where the winter gales that wreck the hardwood trees leave them untouched. This is the more strange as pines rarely root deeply. The roots, even of old trees seventy to one hundred feet in height, rarely go into the earth more than two or three feet, taper rapidly and extend not usually over twenty feet on every side. In young trees twenty or twenty-five feet tall the roots do not penetrate more than fifteen or eighteen inches, yet great old trees stand alone in pasture and on hilltop, exposed to all the fury of the fiercest gales, rarely if ever blown down. The structure of yielding limbs that swing so that the gusts glance on their plumes, and the needle-like leaves that let the torrents of air slip through them, is no doubt the reason for this. The outermost pines of the grove shoulder the gale away from the others, yet let it slip by themselves, giving it no grip whereby to tear them up. The resinous 
roots of the tree not only suffice to hold it upright against the storm, but they last long after the trunk has been cut away. Our forefathers in clear land used to set the uprooted stumps of the pine up in rows for fencing, unsightly barricades that would persist for a century with little sign of decay. On the other hand, wood from the trunk set in the ground soon decays.

Of the great trees centuries old that once clothed our land from Newfoundland to the Dakotas, from northern New Brunswick to southern Pennsylvania, few if any remain. Nor shall anyone see their like here again for centuries. But the pines are coming back again to New England. We know their values now as never before and we are encouraging them to reclothe our solitudes both for their commercial and their sentimental value. This last is great and grows greater, nor need one necessarily go into the storm at midnight to appreciate it. One may get some phases of it there, though, that are not to be found elsewhere. My way home through the storm was rough and wet, but it was not lonely. The songs of the pines went with me, especially the tinkling xylophone dance music of the dryad, deep within the ancient trunk. 


\section{CHAPTER VI \\ NANTUCKET IN APRIL}

It is fabled that nine hundred years ago the Norsemen riding the white horses of the shoals, dismounted upon Nantucket, its original European discoverers. But this is hardly to be believed, for they did not stay there. Conditions the world over have changed much since the day of the Vikings, but still today he who comes to Nantucket must emulate them, and ride the same white horses of the shoals, for they surround the island and prance for the modern steamer as they did for the long Norse ships with the weird figure-heads and the bulwarks of shields. Blown down from New Bedford by a rough nor'wester we plunged through the green rollers south of Hedge Fence shoals, wallowed among the white surges of Cross Rip, and found level water only between the black jetties of Nantucket harbor, where in the roar of bursting waves the white spindrift fluffed and drifted across like dry snow on a January day. 
Within lies the old town, more sedately and unconsciously its very self in April than at any other time of year. The scalloping is done, prohibited by law after the first and the dredges no longer vex the sandy shallows of the land-locked harbor behind gray Coatue. The summer visitor has not yet come and the town is its very, peaceful, indeed slumbrous self. The bustle of the day comes with the arrival of the steamer at four o'clock. From then until darkness falls Main street is busy. The curfew, falling in sweet tones from the old watch tower, voiced by the silver-tongued "Lisbon bell," lulls all to sleep, and indeed long before that only an occasional footfall resounds from the flagging. At seven the same bell rouses all to the morning's leisurely bustle, and again at twelve it rings a noon somnolence in upon Main street that is even more startling to the stranger than the evening quiet.

For the full length of the noon hour one may stand at the door of the Pacific Bank and look down the broad cobblepaved, elm-shaded stretch of Main street to the door of the Pacific Club and be quite deafened by a step on the brick sidewalk and fairly shy at the shadow of a passer, 
so lone is the place. If it were not for the travelling salesmen, a score or so of whom come in with every boat, flood with their tiny tide the two hotels that are open and ebb again the next morning with the outgoing boat, there were even less visible life at this season. Yet Nantucket has today a permanent population of about three thousand, which is swelled to thrice that number when the summer hegira is at its height. That means, including the island, which is at once all one town and with a few tiny off-shoot islands along its shore, all one county, the only instance in Massachusetts where county and town have the same boundaries.

Geologically Nantucket is a terminal moraine, a great hill of till which the once all-prevalent glacier scraped from the mainland and dropped where it now lifts clay cliffs and stretches sandy shoals to the warm waves of the Gulf Stream. Bostonians who know their geology should feel at home in Nantucket, for, while it is superficially allied to Cape Cod, the pebbles of the stratified gravel on the north being in a large part derived from the group of granite rocks known on the neighboring mainland, perhaps half of the mass being of that nature, the remainder is of the fel- 


\section{8}

OLD PLYMOUTH TRAILS

site and felsite-porphyries so common in the region about Boston. Here and there are a few big boulders, believed by geologists to have been dropped by stranding icebergs and without doubt natives of Greenland.

The island holds vegetation also imported from far distant areas and established long before man, civilized man at least, came to it.

On favored uplands one finds the Scotch heather and he might think it had been brought by the loving hand of some Scotchman were it not for the fact that the earliest settlers found it here. They came, these earliest settlers, in 1659 , Thomas Macy and his wife, Edward Starbuck, James Coffin and Isaac Coleman, a boy of twelve, storm-tossed about Cape Cod and over the shoals, all the way from Salisbury. For them the merrymen breakers on the shoals danced as they do for the incomers of today. They were not sailors, not even the master of the ship. Perhaps that is why they kept on to the end of the two hundred-mile voyage. At any rate, they did, and they found the Scotch heather here. Here, too, one finds another strange plant, plentiful over on the sandy peninsula of Coatue, the 
Opuntia or prickly pear, a variety of cactus common enough in Mexico and portions of our Southwest, but surprising on this island.

In these two plants at least east and west stand face to face across Nantucket harbor, the cactus holding the sandspit to the north, the heather on the main island to the south. In April the prickly pear is as ugly as sin to the eye with its lobster-claw growth, uglier still to the hand with its steel-pointed thorns, but later it will put forth wonderful yellow, wild-rose like blooms in rich profusion, making up for all its dourness. Professor Asa Gray, the distinguished botanist of a half century ago, used to say that nothing in the way of plant life could surprise him on Nantucket. Probably this juxtaposition of cactus and heather prompted the feeling.

Nantucket town straggles from beach to hilltop and along shore at its own sweet will, gradually merging into wind-swept moreland on the south and east and west. Here, again, Bostonians should be at home, for the streets grew no doubt from cow-paths winding leisurely from house to pasture, and down them at night, even now, some of them, the cows stray and nibble on the homeward way. I fancy no town so indivi- 


\section{0 \\ OLD PLYMOLTH TRAILS}

dual in its characteristics still remains in the State. The very parements smack of it. Here is an old-time cobblestone, then long, smooth stretches of asphalt. Again, just dirt, and the three meet and mingle in stretches long and short, in whose variations one seeks in vain for a reason. So with sidewalks, brick passes to flagging, to asphalt, to dirt and back again in the distance of half a block. And eren the brick changes often and suddenly. Here it lies flat, ten feet along it is on edge, perhaps ten feet further on end. A blind man could know his exact location in any part of the town simply by the sound of his own footfall on the sidewalk surface beneath him.

So it is with the houses, and I fancy in this lies one great charm of the town to the citybored summer visitor. No doubt every old sea dog was his own architect, and the houses show it from main truck to keelson. Iet hardly in a single instance is the result displeasing, within or without, above decks or below. Instead, there is a fine harmony of contrasts that delights while it rests. As for location, it would seem as if each shipmaster, once he had the structure launched, brought her up at full tide and let her 
lie just where she stranded when the ebb began. So they rest today, jumbled together in friendly neighborliness or slipping down the tide toward the harbor on the one hand and toward the wide high seas of the downs on the other. The town melts into the open either way and belongs to it, merging gently with no possibility of shock or rudeness. So it is with the people, the real Nantucketers. Each intensely individual they yet blend in a wholesome harmonious whole that joins the outside world with little friction. The sailor instinct is strong in them, and they bring their barks alongside the dock or the stranger with a pleasant hail and without a jar.

As the silver-toned Lisbon bell of the Unitarian church tower dominates the sounds of the town so the gilt dome of this church tower dominates the town to the eye of the inbound mariner, as he swings round Brant Point. So, too, in more than one way, since its building in $I S_{I}$, this strong tower has dominated the home life of the city. Its glassed-in crow's nest has been the city's watch tower for a century and more. And so in a measure it is today. The fire alarm system, now modern and electric, warns of fire 
by its means, summoning the firemen to boxes by numbers rung. Yet only a few years ago the old tower was literally a watch-tower, occupied always by one of three superannuated seamen who watched for fires, and seeing one rang the bell and shouted the location to the fire department. One stood watch in the glassed-in octagon above. Two sat by the fire and smoked in a room in the belfry below. If the wind was in the east they put the stove pipe out of a hole in the west side of the tower. If it blew from the west the stove pipe was readily changed to a windowpane on the east side. These watchmen were paid \$350 a year, practically a dollar a day, and they seemed to have been as efficient as the lately installed electrical appliance.

From the crow's nest to the church roof this old tower is pencilled and carved with the names of Nantucketers, written in for the last hundred years and many an otherwise forgotten man and event is thus recorded for the use of future historians. Yet it is safe to say that no man of all the island dwellers ever did or ever will tread the stairs or look from the octagonal windows with a more intense individuality than that of Billy Clark, Nantucket's towncrier, now lamentably 
dead since 1907. Each afternoon he climbed to the crow's nest with horn under his arm to watch for the daily incoming steamer. He could sight it about an hour before it would dock and as soon as he did the horn blew grandly and his voice rang out over the town in a rhyme, doubtless of his own composing.

Hark, hark, hear Billy Clark, He's tooting from the tower,

He sees the boat, she is afloat, She'll be here in an hour.

And so she would, and before she touched the dock Billy deftly caught a bundle of Boston papers and racing uptown sold them all before the passengers were off the boat, unless they moved quickly. But these were but a few of Billy's multitudinous activities. He cried auctions and sales, entertainments of all sorts and if for any reason a public affair must be suddenly postponed the quickest way to get the news about was to slip a half dollar to Billy who forthwith cried the matter with amazing celerity and vehemence from all the street corners, tooting his horn between whiles to get the attention of all. Weekly or oftener Billy used to cry meat auctions in the lower square, which have always 
been a Nantucket institution; at these one bids for his first choice of cuts and having bid highest is allowed such portions and such amounts of the "critter" as he pleases.

Billy Clark made much money, as money was reckoned in his day on the island but he had no faculty for keeping it or even keeping account of it. For thirty years his returns for his newspapers sold were made from time to time to the Boston office in, seemingly, such sums as struck his fancy as being appropriate. These were more than adequate for by and by the office sent down word, "Tell Billy Clark for heaven's sake to quit sending us money. He is too far ahead of us."

As might have been expected Nantucket's town crier died poor and would have been in want had not a subscription paper been started for him by the local paper. This, made up in large part by summer visitors and off-islanders, amounted to several hundred dollars, and at the end there were forty dollars left with which to buy him a tombstone. I have not seen this tombstone. It ought to have a horn neatly graven, but I suppose it has not. The town misses him, needs 
him, more than one citizen says that, but so individualistic a place makes no attempt to get another. There is something of the Quaker idea in that, for though the island was once a great Quaker stronghold few if any of the old sect remain. But it is the Quaker idea. A new town crier will arrive when the spirit moves. Till then the horn is silent. An off-islander might suppose that the town crier was appointed in town meeting as is the fence-viewer, the sealer of weights and measures, the pound-keeper and the hog-reeve. But that is not so. Billy Clark evolved himself, so to speak, and the town patiently waits a second coming.

From the watch tower one looks down manyflued chimneys and sees a score or so of railed-in platforms on the very housetops, often surrounding the chimney. These are the "shipmaster's walks," often known as the "wives' walks." From these one gets a good look off "to sea and can readily fancy wives and sweethearts climbing to them to watch for some whaleship that left port perhaps three years before. I fancy them too high, too breezy and too conspicuous for much walking by these. Thence one may see the 
island round, and get a broad view of the open downs to southward that tempt one to tramp, seeking the edge of the Gulf Stream, led by the steady roar of its breakers pulsing against the clay cliffs. On the downs one gets a sense of the whole of the island as nowhere else. Here it is a ship at sea, unsinkable and steady, blown upon by the free winds of all the world. In the half-gale out of the west I note the smell of the shoals, a suggestion of bilge in the brine, not altogether pleasant. I fancy a heavy sea stirs the slimy depths and brings their ooze uppermost. I had noticed this from an incoming liner's deck when off the lightship before, but charged it to the ship. Now I know it for a strange odor of the sea. It makes me half believe the humorous, oft-told tale of skipper Hackett, who knew his location by tasting the ooze on the tip of the lead. He who

\section{roared to Marden}

Nantucket's sunk and here we are

Right over old Marm Hackett's garden.

In a northwest gale the Nantucketer, though far to the southeast, should be able to locate the shoals and steer home by the smell of the wind. On less uproarious days one gets all along the 


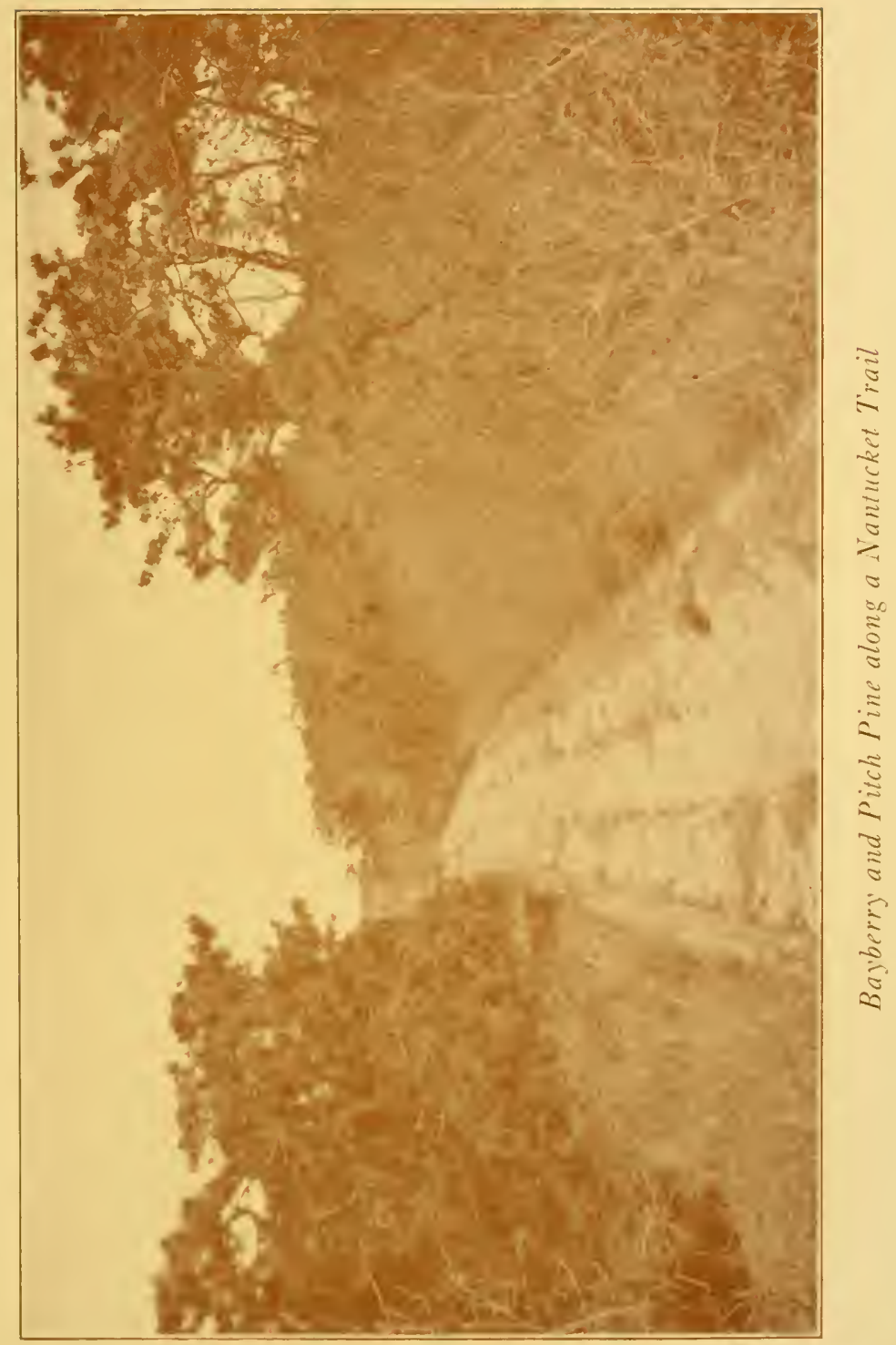





\section{NANTUCKET IN APRIL}

downs the rich, ozonic odor of the deep sea for a fundamental delight. And always with it are the perfumes of the blossoming land. There is tradition of heavy oak timbers once growing on Nantucket, but only the tradition remains. Here now are low forests of stunted pitch pines, sending their rich resinous aroma on all winds. And in late April with these comes the spicy smell of the trailing arbutus, which hides all along the ground among poverty weed, gray cladium moss, and Indian wood grass, sometimes starring the mossy mats of mealy-plum with the pinky-white of its blooms. The mealy-plum itself shows faint coral edging of pink young buds, and here and there a thistle plant, stemless as yet, looks like a green and bristly starfish in the grass. Isolated red cedars on this wind-swept down grow round balls of dense green foliage four or five feet in diameter, looking as if it needed but a blow of an axe at the butt to send them rolling down wind like big tumble weeds. Scrub oaks curiously take the same form, and clumps of bayberry, black huckleberries and sweet fern are often rounded off to hemispheres.

Four silver-toned strokes from the old Lisbon 


\section{8}

OLD PLYMOUTH TRAILS

bell in the watch tower warn of dawn in Nantucket in late April. This bell was one of six cast in a Lisbon, Portugal, foundry, intended for a Portugal convent of much renown. In I8I2, Captain Charles Clasby of Nantucket visited this foundry, bought the bell, which had not yet been dedicated, sending it to the island in the whaleship William and Nancy', Captain Thomas Cary, and in I8I5 it was hung in the tower. Soon after the stroke of four the sparrows begin to chatter, but before long one hears through their uproar the clear whistle of meadow larks. These flit familiarly about the lower levels of the town singing from gate-post or shed-roof all day long and on the downs they vie with the song sparrows in breaking the lone silence of the place. Save for these, a crow or two and the shadow of a sailing hawk, the uplands lack bird life in April.

He who would see birds in plenty, as well as much other wild life, should go over Maddeket way and sit on the shore of Long Pond. There I found the bushy swales alive with marsh birds. Blackbirds gurgled all about. The reedy shallows held many bitterns whose sepulchral "Cahugancagunk, cahungancagunk" sounded ventriloqually from the reeds. Coot, sea duck, loons, 


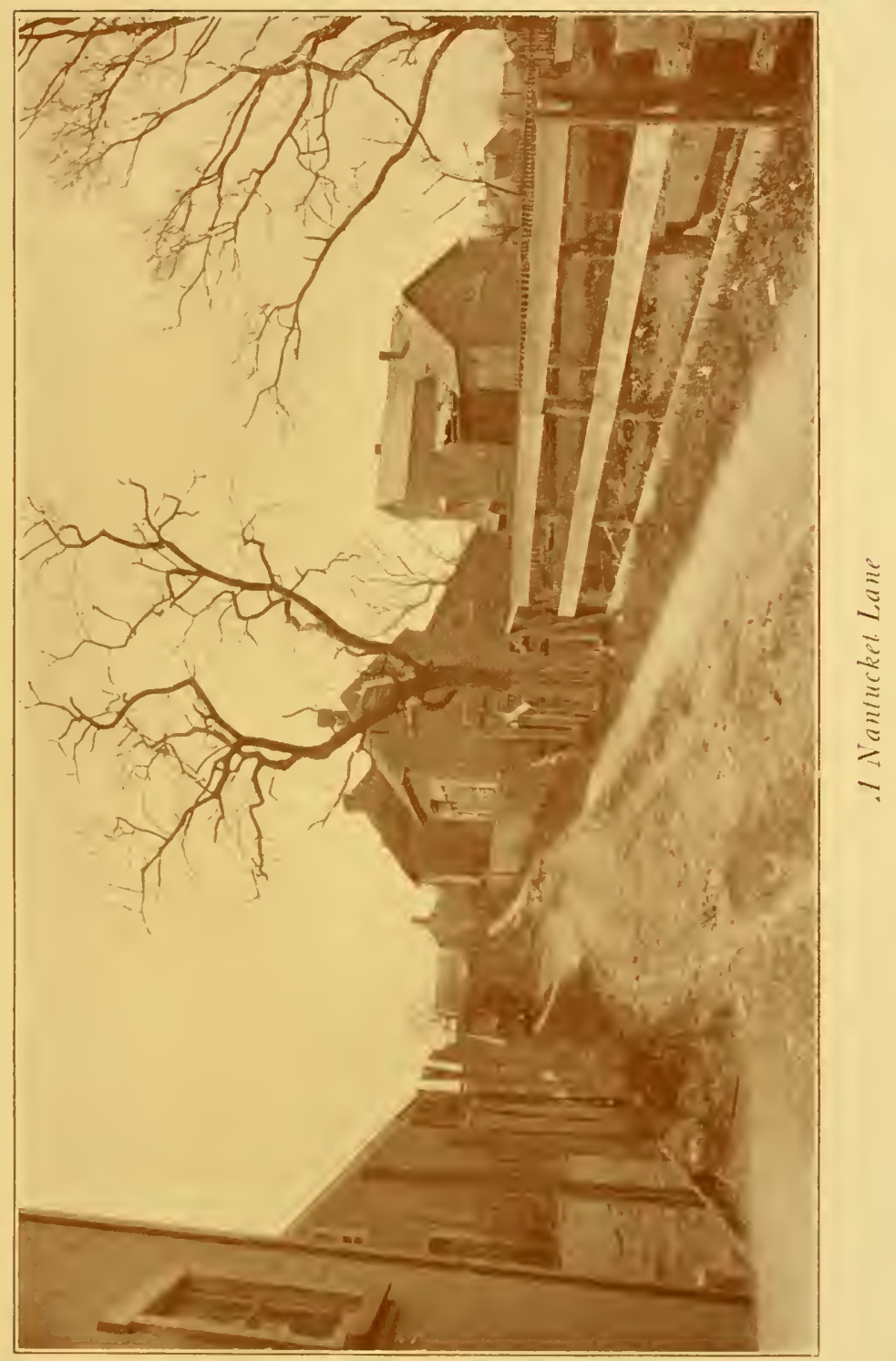



black duck, grebes, dotted the surface of the pond and in all the sandy shallows spawning alewives splashed and played-thousands of them. I had thought spawning a serious business with fish, not to be entered upon lightly or without due consideration. Yet these made a veritable romp of it. And in the crystal clear air overhead, swept clean of all city soot, soared a marsh hawk or two and an osprey. There was more than clarity to this atmosphere. It had an elusive, miragecreating quality that made the osprey look startlingly large as he soared near. It was enough to make one remember the roc that Sindbad saw and get under cover. But he took an alewive instead of me. All along the island in the steep of the sun the air had this magnifying quality. It loomed the white headstones in the cemetery on the hill back of the town till they seemed bigger than the town itself, symbolic perhaps of how large a proportion of its former glory lies here.

Nantucket's one boat out at this time of year leaves at seven in the morning. From its deck across its churning wake the most conspicuous building is the old watch tower whose gilded 
dome gleams friendlily. And as the beams of the morning sun strikes this, like the tower of Memnon, it gives forth music, the silver-tongued call of the old Lisbon bell. "Come back, come back," it cadences to all who pass, the melody clinking clear far over the level sea. It seems the spirit of Nantucket born of its warm spring sun, its soft winds and the friendly lives of the islanders themselves, a pleading that echoes long in the memory and that few can resist. 


\section{CHAPTER VII}

FOOTING IT ACROSS THE CAPE

The Pilgrims might have been envied their discovery of Cape Cod if they had come in the spring of the year. As it was, though they hailed it with joy, it being land anyway, yet they must have found it inexpressibly lonesome and spooky. To the newcomer it is apt to be a ghostly sort of place at any time of year, unless mayhap he be from some similar strand, for its rolling sand hills are swept by winds that wail, and beaten by a sea that grumbles when it does not cry aloud. At the time of year when Standish and his men patrolled its beaches, it is no wonder they sav savages behind every liliputian pitch pine and heard them shouting in the wind and sea. So far as the records go the Icelanders came first of all and Thorfinn Karlsefne, who set sail about I000 A. D., called the place "Furdurstandir," or wonderstrands, perhaps because of the immense stretches of sea beach along the outside, but quite as likely on account of the mirage 
which so often greets one in the region thereabouts. A much later explorer tells how the curious atmospheric effects made the land seem to tip up in front of him in whichever direction he walked, making level land and even downhill look like uphill, so uplifting is the Cape air.

Gosnold was perhaps the first Englishman to set foot there, doing it first in 1602 and coming again, as we all must, once we know the region. Gosnold and his men got the eerie feel of the place too when the winter approached. They colonized Cuttyhunk and did very well through the summer, digging sassafras by day and retreating to their fort on the little island in the pond on the bigger island every time the goblins chased them. But the shouting of warlocks in the autumn gales was too much for them and they reembarked for England, glad to get away from the land which was so beautiful and so strange.

A dozen years later came Captain John Smith, who feared neither man nor devil, and who saw nothing unprosaic about the place. As mariner and cartographer to him it was a cape, and nothing more. "Cape Cod," he writes, "which next 


\section{FOOTING IT ACROSS THE CAPE $8_{3}$}

presents itself, is only a headland of hills of sand, overgrown with scrubby pines, hurts and such trash, but an excellent harbor in all weathers. The Cape is made of the main sea on one side, and a great bay on the other in the form of a sickle. On it doth inhabit the people of Pawmet, and in the bottom of the Bay those of Chawum."

The bottom of the bay means the region of Barnstable and west, and the people of "Chawum" were the Indians of that region. The word sounds dangerous and suggests cannibals, which I do not believe the Indians were, even in those days. Perhaps it refers to their chief, who may well have been an aboriginal Dr. Fletcher. The word "hurts" is more difficult to dispose of but I find it was just his way-and indeed the way of the English of his time-of saying huckleberry. That delectable fruit which is so common on the Cape ought to have a name more significant of its delectability, but perhaps the original sponsors ate it before it was ripe, or too much. Hurts is short for hurtleberry, which is another way of writing whortleberry, the correct old English form which we have since corrupted 
into huckleberry. That Smith should have classed the Cape huckleberries as "such trash" is proper cause for a riot.

Two and a half centuries later came Thoreau, the very prince of explorers, for he can take one over well trodden ways and through familiar fields and show him India and the Arctic regions. Patagonia and Panama in one sweeping glance along a sand hill. Cape Cod was as full of romance of remote regions as was Concord. He, too, notes the mirage. "Objects on the beach," he says, "whether men or inanimate things, look not only exceedingly grotesque, but much larger and more wonderful than they actually are. Later, when approaching the seashore several degrees south of this, I saw before me, seemingly half a mile distant, what appeared like bold and rugged cliffs on the beach fifteen feet high and whitened by the sun and waves; but after a few steps it proved to be low heaps of rags-part of the cargo of a wrecked vessel-scarcely more than a foot in height." " Thoreau felt the eerie strangeness of beach and sand dunes as all explorers have, and he noted, too, the characteristics of the sand and its vegetation and of the inhabitants with a humorous minuteness. Writing of 


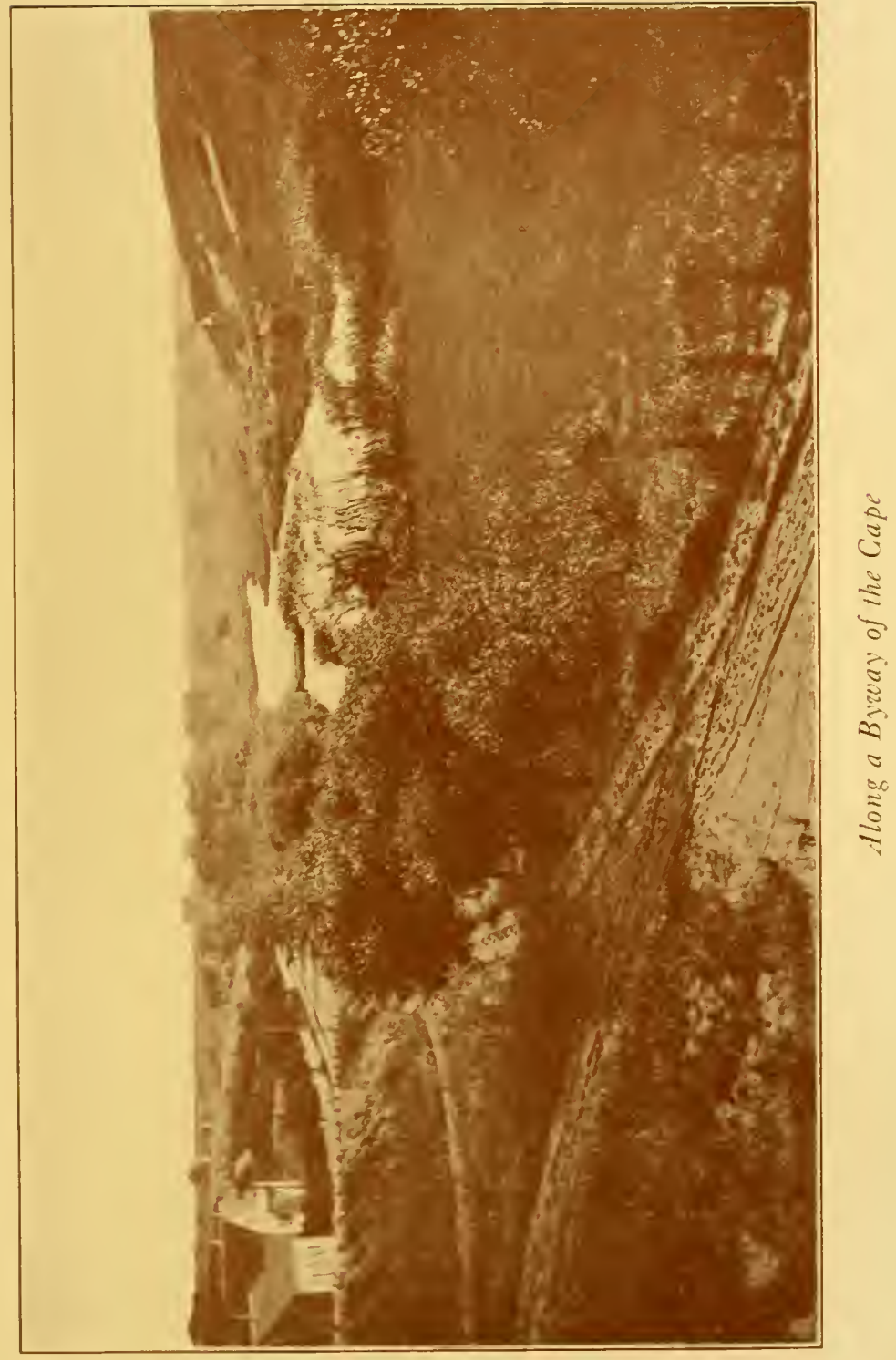




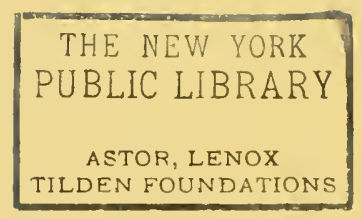




\section{FOOTING IT ACROSS THE CAPE 85}

the dunes, which seem always about to overwhelm Provincetown, he says, "Some say that while the Government is planting beach grass behind the town for the protection of the harbor, the inhabitants are rolling the sand into the harbor in wheel-barrows, in order to make houselots," which seems characteristic of the beach grass, the harbor and the Cape Cod spirit of making the most of real estate opportunities to this day.

"Thus Cape Cod is anchored to the heavens, as it were," he goes on, "by a myriad little cables of beach grass, and, if they should fail would become a total wreck, and ere long go to the bottom. Formerly the cows were permitted to go at large, and they ate many strands of the cable by which the Cape is moored, and well-nigh set it adrift, as the bull did the boat that was moored by a grass rope, but now they are not permitted to wander."

All of which would seem to prove that Thoreau liked to crack a sly joke at the region he loved, as well as do the rest of us. The other day I too crossed the Cape, not exactly in Thoreau's footsteps but through the region of the "Chawums," which, I take it, are the Mashpees of later days. The trail began at East Sand- 
wich where the sandy road crosses the State highway and goes on up the sandhills, always with the blue of the sea teasing from behind the keen javelin of the north wind pushing me on southward. It was wonderful, that blue of the cold, wind-beaten sea. It shone through the maze of mingled twigs for miles till I finally lost it in topping the plateau, passing from loose sand to clayey bottom and fairer growth in moister and more fertile soil. One fascination of the region comes in the fact that in a few rods one leaves all trace of civilization behind, unless one may call the narrow road a trace, and traverses the Cape Cod wilderness for mile on mile, just such a wilderness as Thorfinn Karlsefne may have tramped in armor with spear and crossbow of his day, such as Myles Standish and his men shivered through or Verrazani and Captain John Smith marched over and mapped. Pitch pines, small oaks of many varieties with an undergrowth "trash" of "hurts" and scrub oaks make up the forest which presses narrow cart paths and hangs over them. All the way up the slope the persistent chill of the north wind filled the air with the tonic tang of brine and held back the gray-green mist of leaves that strained at 


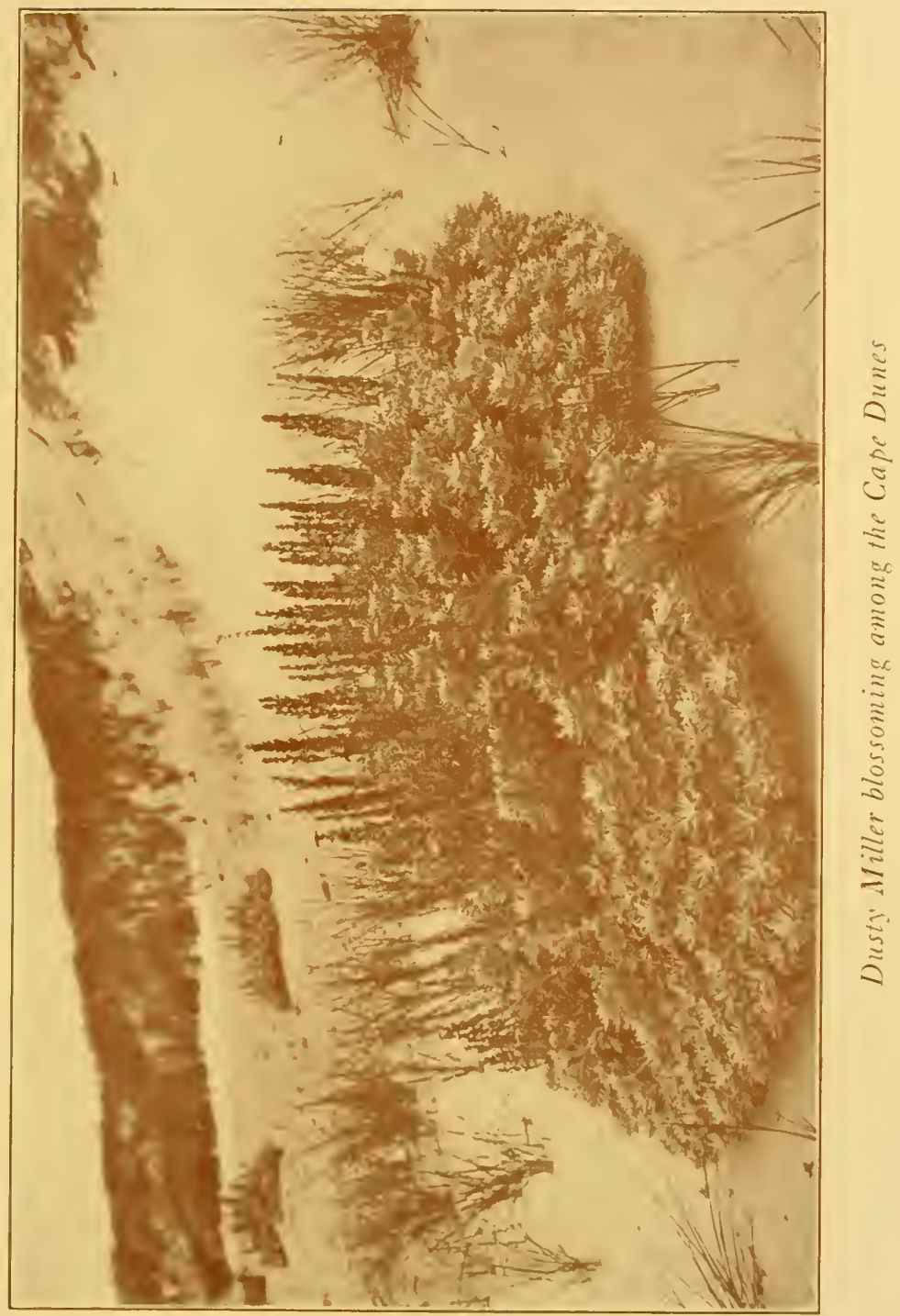



the buds, eager to be out. In hollows the spring had come. On ridges it delayed, finding the auguries unfavorable and waiting a new voice from the altar. But wherever the sun shone in and the wind was stayed it had loosed the butterflies that soared or flitted or flipped about in joy of long awaited warmth. Broad wings of goldmargined, brown Vanessa antiopa soared serenely along under overarching white oaks. "Little Miss Lavender" folded her gray-blue wings in demure beauty on the gray cladiummossed stumps by the roadside, and duskywinged species of the skipper brood were agile with new-born life, yet glad to fold wings and sleep in the sun on the road. These were sprites of the deep forest. None were visible in the town margin, though perhaps it was the sweep of the north wind that kept them away. Bird regions, too, showed a definite demarcation. In the orchards and open fields of the town were the home-loving birds, bluebirds, robins, song and other sparrows, swallows, and in the marshes the red-wing blackbirds. Not one of these did I see after leaving the open spaces behind. The avifauna of the scrub-oak underbrush and of the white oak and pitch-pine trees overhead was as 


\section{8}

distinct as that of a new continent. A flight of pine warblers was on and the oaks and pitch pines were alive with them. The juncos had gone north to nest in flocks of thousands, in a wonder of full song, all eagerly pressing on towards the hills but they left their songs behind them, as it were, to be sung by the other birds. In the pastures and cultivated fields the chipping sparrows, newly arrived from the South, took up the trill with an accent of their own, and all the pine warblers sang it, each with an individuality that slirhtly but clearly marked him from his fellow. I think all birds show this slight but definite individuality in manner and voice and are probably known to their neighbors of the same clan, as we are, each by his voice. And even so simple and definite a thing as the pine warbler's song may be varied by the individual singer from time to time. I heard one fine bird singing in the stereotyped form. As he sang a flicker flicked in the distance. Whereupon the pine warbler sang again, the same trill but with a tittering twang about it that just jocosely imitated the flicker. I saw no other warbler or other bird near enough to be the beneficiary of this 
FOOTING IT ACROSS THE CAPE 89

joke. He did it just for himself, and his motions as he flew over to the next tree seemed a visible chuckle that ended in a saucy flirt of the two white tall feathers which are one distinguishing mark of the bird in flight.

Other warblers I noted none. The woods seemed given up for the occasion to Dendroica vigorsi.

The wood warblers disappeared at the border line of the open fields at Wakeby and the homeloving birds appeared again in numbers, robins, bluebirds, swallows and the sparrow kind. The downy woodpeckers and flickers, to be sure, passed to and from both zones, though they, too, seemed to love the trees of the open rather than those of the deeper wood, but in the main the boundary line, as usual, was quite distinctly marked. The noon sun was high and the north wind's chill had been fairly combed out of it by the bristly harrows of a thousand pine tops. In its place was a warm, resinous fragrance, an incense to the season. The heart of the Cape forest is passed at Wakeby and the blue waters of a great lake lap in crystal clearness on the clean sands. The Cape sands are a vast water filter 
and strain out of the streams all sediment. The ponds are liquid crystals in narrow settings of pale gold.

Someone told me it was only eight miles across the Cape from East Sandwich to Cotuit. Perhaps it is as the crow flies, but I could not clear the scrub as they do and I found the roads adapted to delightful leisure. No wonder the Cape folk do not hurry. How could they? The narrow, gray ribbon of road strolled with me through what seemed eight miles of forest before we reached Wakeby.

Somewhere along there the holly stood green and statuesque in occasional clumps. And thus we fared on to Mashpee. The Mashpees, very mild and genial descendants of the "Chawums," if descendants they are, live quietly in little yellow houses that do not look prosperous, though the children are fat and the elders contented. Modern civilization has reached them in phonographs, bicycles and folding baby-carriages, if the shingles are vanishing from the roof. In I620 Mashpee was their chief and they lived in wigwams. But the last pure blood died in ISo4.

Nauhaut, one of the deacons of the Cape Indian church, which seems to have thrived a cen- 


\section{FOOTING IT ACROSS THE CAPE 9I}

tury or two ago, was the hero of a wonderous snake story which, if it were not about a deacon, one might think apocryphal. I did not see a black snake on the whole journey, but they are common enough even now and were once perhaps much more so. At any rate Nauhaut was attacked by a whole ring of them-so the story runs-which approached him from all sides, the. snakes with black heads raised and hissing venomously. Nauhaut with true Indian strategy stool still as they approached, and even when the largest of them twined about his legs and climbed to his neck he made no move other than to open his mouth wide. The chieftain snake thrust his head into this mouth with its glistening white teeth, and Nauhaut immediately bit the head off. Thereupon panic fear seized the other snakes and they fled, leaving the deacon master of the battleground. The Cape grows some big black snakes to this day, but none like those, nor have any later stories appeared to match.

The Cape has informative guide boards, though whether the facts match the information I am not quite so sure. Perhaps, sailor-like, I was circumnavigating Cotuit, beating in, as one 
might say, instead of sailing directly to port, for I found three guideboards at intervals of a mile or two and each announced with monotonous regularity that it was two and a half miles to Cotuit. When it comes to making statements the Cape guideboards stand loyally by one another. But the little town hove above the horizon at last with its lovely blue bay of warm Gulf-stream water, set in a sweet curve of white sand and backed by neat cottages bowered in green trees. It is worth walking across the Cape to reach Cotuit at the journey's end, but I doubt the eight miles. If it is not fifteen by way of Wakeby, Mashpee, Santuit and the rest I am mightily mistaken.

Thoreau with his usual clear gift of prophecy said of the Cape: "The time must come when this coast will be a place of resort for those New Englanders who really wish to visit the seaside. At present it is wholly unknown to the fashionable world and probably it will never be agreeable to them. If it is merely a ten-pin alley, or a circular railway or an ocean of mint julep, that the visitor is in search of-if he thinks more of the wine than the brine, as I suspect some do at Newport-I trust that for a long time he will be 
FOOTING IT ACROSS THE CAPE 93

disappointed here. But this shore will never be more attractive than it is now. Such beaches as are fashionable are here made and unmade in a day, I may almost say, by the sea shifting the sands. Lynn and Nantucket! this bare and bended arm it is that makes the bay in which they lie so snugly. What are springs and waterfalls? Here is the spring of springs, the waterfall of waterfalls. A storm in the winter is the time to visit it -a lighthouse or a fisherman's hut the true hotel. A man may stand there and put all America behind him."

This was all true in Thoreau's day and long after. But the fashionable world has since found the Cape, and brought its palatial hotels and its million-dollar cottages to sit down in friendly fashion among the villagers and share their summer life with them. Thereby both are benefited. But after all the chief charm of the Cape is still that vast stretches of it are as free from fashion as Thoreau said they always would be, and the forests like those Captain John Smith and Myles Standish, Karlsefne and Verrizana traversed still grow there in wide stretches. 


\section{CHAPTER VIII \\ WILD APPLE TREES}

Coming back to my pastures after long absence I am always surprised and often otherwise moved at the changes which I can then clearly see have taken place in them. Had I frequented them day by day these would never have appeared to me. Just as in the countenances of one's best friends, seen often, there seem to be no mutations and we need to think definitely of some past period and then to compare the impression with the present one to see that the child is growing up or the old man growing older, so it is with the face of the earth in familiar spots. Young growth comes little by little, shoulders bow day by day in the aged, yet we do not see it when we dwell constantly with them. It is only after long absence that these things suddenly presented shock us with grief in the one case or touch us with pleasure in the other. After a summer's absence, you find baby shrubs grown to youth and youthful trees putting on a greater 
air of maturity than they had before. Coming back in spring you are apt to sorrow over the wrecks which the winter has wrought. Last winter's gales and deep snows, and more than all the ice storms, have left havoc behind them whereby you may trace their durance and their intensity. Tall birches whose resiliency never before failed them were so bowed beneath these storm burdens that they still remain with upper. branches sweeping the ground, like white slaves sculptured in graceful but profound obeisance before a storm king that has long since swept on with all his retinue. It is strange to see cedars that have always seemed unbendable models of primness and rectitude bowed and distorted in groups by the same resistless force. Very heavy and long continuing must have been the ice on these to thus permanently crook their red heartwood. The heavy brand of the Northern winter yet marks them for his own.

Yet the pastures are so glad with May that it is easy to forget sorrow for the passing old in joy over the surgent beauty of new life. It is easy now to believe what the botanists tell usthat flower and leaf are but slightly differentiated forms of the same impulse of growth, grading 
almost imperceptibly one into the other. With new leaves half-grown, with blossoms bursting, it is hard to tell without close inspection which is which, so tender and rich are the colors which unfold from all buds. The yellow of the dandelion, the blue of wood violets, and the purple of the wild cranesbill are not more delicate, nor are they so rich as the red of the young leaves of the white oaks, now as large as a mouse's ear, which is the Indian sign for the time to plant corn. The blossoms of the berry bushes are no more flower-like than the young leaves among which they grow. The green-yellow of barberry blooms is not more fervent than the yellow-green of the tender foliage, and the two colors blend into one burning bush of cool flame. I do not wonder the summer yellow-bird loves to build his nest in the barberry bush. Its colors at this season are his own.

Other surprises meet men in the pasture this spring. There is a particularly beautiful corner which many city people have come to share with me. On holidays and Sundays they troop to their bungalow on the pond shore by the hundred. Yet they must love barberry bushes and sweetfern, red cedar and white pine, as I do, for they 
have not intruded upon them, but have let their own presence slip quietly into the vacant places, leaving the original proprietors of the spot unvexed. In this I see a new variety of city man and woman growing up. A score of years ago the advent of such a horde would have meant more disaster than the winter's ice storms could have wrought. Between these more kindly adventurers and the pasture folk have grown up a friendly intimacy which is beginning to teach city ways to the pasture denizens. Therein lies the cause of my surprise. Under the soft mists of a cool May day I brushed the dew from the wood grasses and unrolling croziers of cinnamon fern to pause in admiration at shrubs and trees bearing calling cards. Here is a red cedar announcing on a Dennison tag, "I am Juniperus virginiana, known to my intimates as savin." Out of its nimbus of pale yellow flame "Berberis vulgaris" hands me a bit of pasteboard, and dangling from a resinous bough is the statement that it is "Pinus strobus" that welcomes me to fragrant shade. Like many city manners which are new to country folk these seem to be a bit obtrusive at first. Yet on second thought I find it an excellent custom which ought to be enlarged upon 


\section{OLD PLYMOUTH TRAILS}

in various ways. I can fancy people coming to the bungalow for a day's intercourse with the pasture shrubs that have never before met them, and feeling awkward and disconcerted at not being able to recall names after a wholesale introduction. I have felt that way myself after undergoing a rapid-fire presentation to a room full of people. If, like the pasture shrubs in this particular corner of the pasture world, all these could have worn a name and address on coat-lapel or corsage, I had come up to the second round able to call each fearlessly by name and oftentimes save mutual emibarrassment.

But there are minor considerations, after all. I have an idea that the pasture shrubs may never take kindly to thus carrying conventional calling cards, and that shyer still and more nimble-footed friends will finally relieve them of what wind and rain have left. In a year or two I shall find the cards nameless and built in as foundations of nests of jay birds and white-footed mice, or worked up more skillfully yet by white-faced hornets into the gray paper of their nests. This is a carefully adjusted world and the instinctive movements of all creatures go to the keeping of the perfect balance. The normal attacks the 
abnormal immediately and all along the line. With shrub or bird or beast to exceed the worldold conventions is to be firmly thrust back into the adjustment or wiped out.

Yet, now and then the balance is not exactly disturbed, but rather readjusted by some alien that seems to find a foothold through all opposition and establishes a place through pure vigor and sweetness of character. Of such is the apple tree that came out of the East with other beginnings of civilization, reaching the shores of Western Europe by way of Greece and Rome. Thence it passed with the early Puritans to New England. A pampered denizen of the orchard and garden for a century or two the tree, so far as New England is concerned, seems to be steadily passing to the wild state. Old orchards grow up to pasture and woodland and the trees of a century ago hold on, if at all, in spite of the encroachments of their surroundings. Thus the best of grafted trees pass to the wild state through decay and regrowth, the strength and sweetness of the wood seeming to bear up against all adversity. The old-time trunk rots away, but sprouts from below the graft spring up and the tree reverts to the primitive in habit as well as 
surroundings. Or seeds, planted by bird or squirrel grow up in rich, modest humus among rough rocks where never a plough could pass and we have some new variety, a veritable wild apple with no semblance of the original fruit about it but often a delectable, wild tang, a flavor and perfume such as no cultivated variety ever had. No tree gives more beauty to the wildest of New England woods and pastures today than this. Innocent of pruning knife or fertilizer its growth has a rugged picturesqueness about it that makes the well trained tree look pusillanimously conventional beside it. I think the perfume of its blossoms is richer and carries farther and I know the pink of the petals is fairer. The wild apple is the queen of all pasture trees today and does not need to bear a tag for the most cityfied man, the most boudoir-encysted woman to know it. To get beneath an apple tree, even in the wildest and most unfrequented portion of the pasture or woodland, is to all of us like finding one's rooftree once more. The race seems to have been brought up beneath it and I take it for a sign of decadence in the New England character that we no longer plant orchards. It is fortunate for us all that the wild creatures are doing what man 
will not and it may be that their planting will some day give us so beautiful and well flavored a wild apple that we too shall be moved to plant and the country blossom with orchards once more. All the best varieties were thus seedlings originally and have been perpetuated by transferring their buds to the limbs of less valued stock.

Tust as in man bone and sinew count really for little and it is only the subtle essence of being, the spirit behind and within, that matters, so it is the sweet and kindly soul within the apple tree that radiates love to all comers. In appleblossom time the bees will desert all other flowers for them, not because the honey is sweeter or more plentiful within them but because the wooing fragrance has more of a pull on their heart strings than any other. Again in the late autumn they come to the ripe fruit for final winter stores, drawn by the same subtle essence, distilled from disintegrating, pulpy cells. I believe the first cider making was a rude attempt to imprison and perpetuate this charm, rather than to simply make a spirituous liquor. So richly does the apple tree give forth this spirit of generous delight that to all of us the trees seem to brood and 
radiate a feeling of parental protection. Man often voices this, and in ancient times there were ceremonies which recognized the tree as a kindly deity to whom reverence was done and thanks given. To "wassail" the trees was more than a jovial excuse for cider and song, it had roots in a deeper feeling of reverence and gratitude. But those humbler than men have the same feeling. In the pastures I often find the apple trees literally brooding seedling cedars which seem to flock beneath the outstretched and low-hanging boughs as chickens huddle beneath the mother hen for protection and warmth. Where tender nurslings of this sort are scattered wide in other portions of the pastures to find them grouped here by the score means that some selective thought has brought it all about. I cannot, of course, say that the seedlings consciously choose. Nevertheless, somehow, that spirit of protecting love of which I am, myself, definitely conscious when I come near an apple tree has somehow drawn beneath it these plants of other fibre that need its shelter.

To more sentient beings we may accord a more conscious purpose, and that the wild apple tree is more beloved of bird and beast than any 
other proves that they, too, feel the brooding charm which radiates from it. Verily, a tree is known by its nests. It seems as if the apple tree took loving thought and prepared especially for certain varieties while welcoming all. The robin loves a solid foundation for the mud bottom and sides of his substantial home. On the levelgrowing apple tree limb he finds this, and the kindly tree throws out little curved, finger-like fruiting twigs from the sides of its big limbs that help anchor the structure against all winds. Farther up on the limb and near the slenderer tip these curved fruiting twigs multiply and suggest the very shape of his nest to the chipping sparrow who loves to twine tiny roots and grasses, and especially horsehair, among them till his own light, wee structure is as securely placed as the cement bungalow of the bigger bird. So, too, the tyrant flycatcher loves to build his larger nest, often interwoven with waste string till it looks as if he had tied it on. He seeks the very tip of the level limb and the blunt, sturdy, spreading twigs invite his confidence as they do that of the chipping sparrow. This bold exposure of eggs and nestlings invites thieving jays and murderous crows, hawks and owls, but the king- 


\section{IO4 OLD PLYMOUTH TRAILS}

bird's dinner flies by while he waits, and he does police duty while he watches for it. $\mathrm{He}$ is rightly named and no marauder dares approach while he sits dominant on the topmost bough. $\mathrm{He}$ is guardian thus of his less belligerent neighbors.

The oriole, trained in tropic woodlands to avoid climbers, instinctively finds the pendulous tips of slender elm boughs the best place for his nest, yet often in apple-blossom time he becomes so enamored of them that the white snow of their falling petals leaves him building on the twigs from which they scatter. In July the incessant, cry-baby twittering of the young orioles is thus as common a sound of the orchard and pasture as it is of the elm-shaded street. Other apple tree nest-hangers are the vireos, yellow throated, red-eyed and white-eyed, all of whom love to build on the low-swinging tips of the benedictory limbs. It seems to me that no other tree attracts such a variety of beautiful birds out of what one might think to be their usual environment. Of these I may cite the scarlet tanager and the rosebreasted grosbeak, both rather shy woodland dwellers, the tanager the friend of the tall timber, the grosbeak partial to sprout land and sec- 


\section{WILD APPLE TREES}

ond growth, but both often found building their nests on the inviting boughs of apple trees not far from their favorite haunts.

It seems, too, as if the tree made especial preparation for the housing of other less shy folk. I know no other tree so nobly hollow-hearted. At little excuse, if it be not good will toward woodpeckers, bluebirds and their like, the mahogany-like dense heart-wood rots, leaving hollow passages in the trunk and larger limbs, and often in the smaller ones, too. Here are homes for all who seek complete seclusion from storms and enemies. The little screech owl loves these hollows more than those of any other tree, and sings his little quavering night song from the dusky tops, while his mate and her eggs are safely hidden in the blackness of the hollow below. The downy woodpecker bores his nest hole in the softened heart-wood of upright limbs and pays for his lodging by devouring all grubs and borers that otherwise might make his house fall too soon. The bluebird finds his dwelling ready made, lower down, often in a horizontal limb, having neither strength nor inclination to bore for himself. The flicker, too, loves the apple tree and bores his own hole in upright limbs, as 
does the downy woodpecker, often with much noise and obtrusion of vigorous chips.

Nor need the list stop here. The red squirrel and the gray, the bat, the field mouse and the white-footed mouse all feel this welcoming charm, this endearing hospitality of the wild apple tree, whether born wild or grown wild through neglect, and go to it for protection, for food, for a home, or just because, like man, they love it and feel sweetened and heartened in its presence.

Soon now the snow of falling petals will whiten the ground beneath all wild apple trees, carrying an inexpressible purity and fragrance to the rich wild earth beneath. Whither these melt it is hard to say. They whiten the ground for a few brief hours and are gone. I can fancy the wee sprites of earth in whatever form they happen to dwell at the moment, beetle or bumblebee, eft or elve, gathering these eagerly by scent and by sight, to store them away below ground for slow transmutations of their own. If wrapped in bedclothing like this it is no miracle that rough grubs should come forth gauzy winged and beautiful insects that flit by and delight the eye of the naturalist. If fed upon these it is no wonder 
that summer wild flowers of the deep woods can show us delicate tints and woo us with dainty perfumes, the very memory of which is happiness for long after. Thus the tree makes kindly messengers of even the rough winds of March that sometimes charge back upon us for a day, obliging them to carry the very essence of the gentle good will and fondness of the spring farther than it might otherwise reach and finally bidding them faint and die for very love of the perfume and beauty they bear. Thus the wild apple tree, still the brooding mother of all woodland things, sends fragrant love and kindness questing far through the rougher woodland till its gentle spirit seems to imbue all things. In all the pastures there is none like it. 


\section{CHAPTER IX}

\section{MIDSUMMER MOONLIGHT}

All through the afternoon of the fervent July day I could see the sun sifting and winnowing his gold for the sunset. All the morning his alchemic forces had been quietly transmuting gray mists of midnight, vapors from damp humus, moisture from lush leaves and I know not what other pure though common elements into the precious glow that began to haze the west soon after noon. The old belief that the alchemist at his utmost cunning could recreate rose blooms from their own ashes had sure foundation. I have seen the sun do it every June in countless gardens where, out of this same humus and soft rains, his potency works the transmutation as if in a night. So on July days this father of transmuters melts in his crucible, of which the earth under our feet seems always the very bottom of the bowl, many ingredients, and distils from them this pure gold. Soon after he passes the meridian you may see it sprinkled lavishly from zenith I08 
to horizon, and as the day wanes it gilds all sordid things with the glow of romance. By it we get the clearer vision and have thoughts of the unseen things which are eternal. The trouble with sordid souls, if such there be, is that they have never seen enough sunsets. People who live in places or palaces where these are never seen have need to be born of noble fathers and sweet mothers, to be carefully nurtured in hope and aspiration and belief, or the world is the worse for them.

Long after the sun had gone and the evening was cool with unclotted dew, the fires of the melting burned high in the upper air and the gold that had been thin vapor seemed to condense into clouds that glowed copper-red with the molten metal and cooled and dropped into the distant hills. No wonder the miners go ever westward for the precious gold, to Colorado and Nevada and California, to Sitka and the Copper River, to Anvil City and the Nome beach and across the straits to Siberia. Never a clear night falls but they see the alchemy at work and the precious element going down in dust and nuggets and wide lodes behind the peaks and into the cañons just beyond. 
Usually it is not until the gold begins to pass that I notice the nighthawk, though he may have been circling and crying "peent, peent" all the afternoon. If you can catch sight of him before the light fades too much you will see the white bar which crosses each wing beneath and looks exactly like a hole, as if the bird had transparencies in his pinions as has the polyphemus moth. Many a summer afternoon I have seen nighthawks circling erratically above Boston Common, and there their cry has sounded like a plaint. No doubt these birds fly there by choice and bring up their young on the tops of Back Bay buildings because they prefer the place, but this has not prevented a tinge of melancholy in their voices. Like many another city dweller they may take habit for preference, but the longing for the freedom of the woods, though unconscious, will voice itself some way. The nighthawk's cry, falling from the high gold of the waning sunset to dusky pasture glades, has no note of melancholy but a soothing sleepiness about it that makes it a lullaby of contentment. I rarely hear him after dark. I fancy he goes higher and higher to keep in the soft radiance of the fading glow. Only once have I ever seen one sky-coasting, falling 


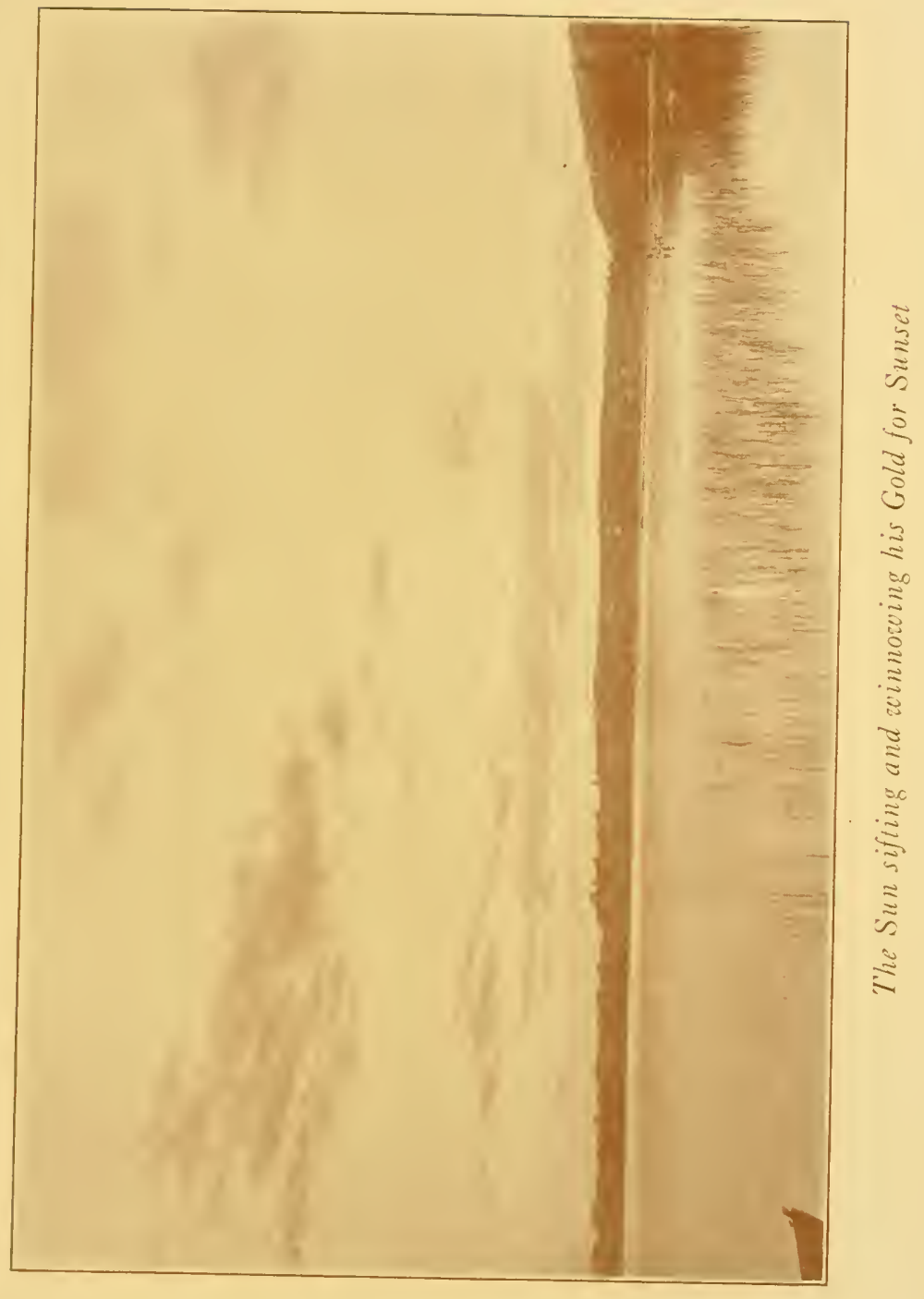


a 
like a dark star from a height where he seemed but a mote in the gold, a smaller, point that the green glint of a real star that had just come through. It was as if his wings had lost their hold on the thinner air of this remote height. He half shut them to his body and dived head foremost on a perilous slant. Then, just as he must be dashed to pieces on the gray rock of the ledge on which I sat, he spread them wide, caught the air that sang through the wide-spread primaries with a clear, deep-toned note, and rose again; and in his "peent, peent" was a quaint note of self-satisfaction and self-praise.

It is customary to ascribe actions of this sort on the part of a bird to a desire to please and astound the mate who is supposed to look on with fervent admiration. Sometimes this may be the case, but I think more often the bird, like my nighthawk, does it to please himself. There was no mate in sight when this nighthawk did his sky coasting, nor did any appear afterward. It was after the mating season and I think the bird did it in just pure joy in his own dare-deviltry. He liked to see how near he could come to breaking his neck without actually doing it. In the same way a male woodcock will keep up his 
shadow-dancing antics long after the nesting season is over, and the partridge drums more or less the year around. The other bird may have much admiration for these actions if she sees them, but never half so much as the bird who performs. Nothing could equal that.

The most beautiful moonlight nights we have are those on which the moon is an hour or two late. Then we see the day merge into real darkness as velvety shadows slip quietly up out of the earth and dance together. These congregated under the pines at first, last night, and waited a bit before they dared the shelter of deciduous trees. Long after that they huddled on the margins of the open pasture as bathers do on the pond shore when the water is cold, seeming to put dark toes into the clear light and then withdraw with a shudder. When they all went in I do not know, for I was watching the sky. By and by I looked back at the pasture and the open places in the wood, and all alike were filled with a wavering crowd that seemed to trip lightly and noiselessly as if in a minuet. Little by little they blotted out familiar outlines till only the tallest of pines looming dark against the lighter 


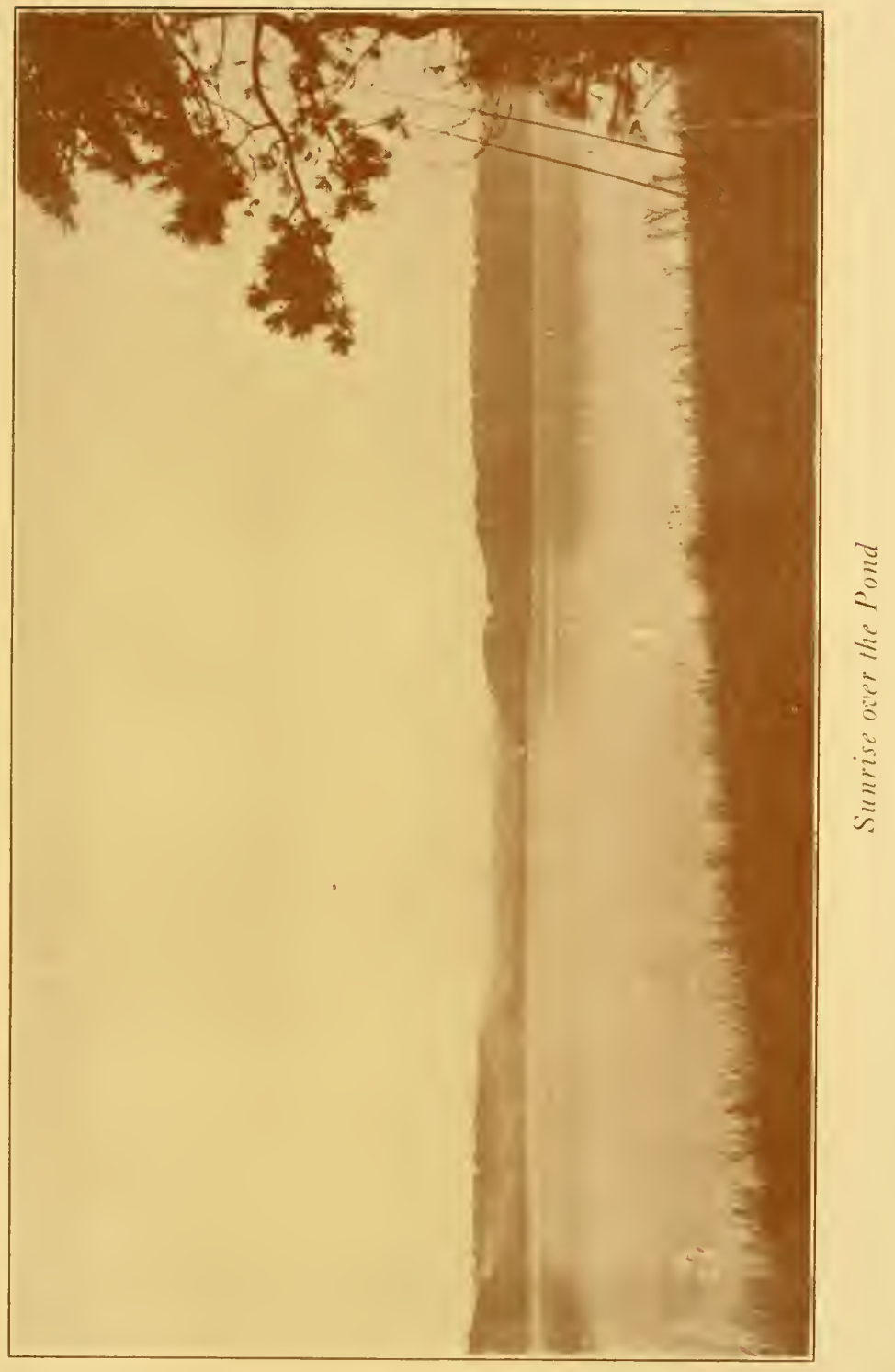




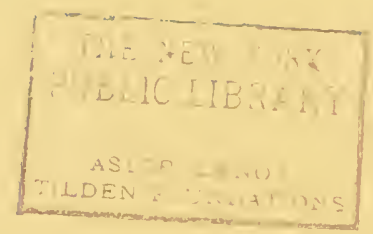


horizon had form. All else was a void, not that of chaos but a soft cosmos of completion.

It is singular how long one may look at this complete darkness and not note the dancing lights in it. After you see them, the glint of the freflies flitting hither and thither, starring the meadows as thickly as distant suns star the sky, making a milky way of the brookside and flashing comet-like along the dry upland, is singularly vivid. They sparkle, these northern fireflies of ours, with a dainty glint that merely emphasizes the darkness. Now and then you may see the larva of one of these, which is the glow-worm beside the path. You may get a very faint real illumination from him, lighting perhaps the space of your fingernail as he crawls along. He, too, merely serves to make the darkness visible. The firefly of the tropics is more spectacular. He blazes forth like a meteor, setting all the thicket aglow for a moment. The lights of our fireflies are more like a frosting of the darkness, as when the moon shines in winter and the light glints from ice crystals hung on the frozen grass. I like ours best.

The herald of the moon is the whippoor-will. 


\section{4 OLD PLYMOUTH TRAILS}

I do not recall hearing him sing on pitch black nights. Starshine is enough for him, but I am convinced that he is only half nocturnal and that he watches for signs of moonlight as eagerly as I do. Last night I saw the glint of it in the upper sky an hour before the moon rose, a silvery shine which did not touch the lower atmosphere, but shot athwart the higher stars like a ghost of aurora. The whippoor-will saw it, too, and began his call, which I do not find a melancholy plaint, but rather an eager asking. It was a voice of shrill longing, sounding out of luminous loneliness after the moon began to silver all things. Slowly, like a benediction, this silvery luminosity descended till it touched the tops of eastward hills with the softest imaginable glow and filled all the sky above them with light. The glow of the sun drives the darkness before it and then appears. The glow of the moon is so much the more gentle in that it fills the world with radiance and leaves the darkness, which it permeates, but does not destroy. It is a newer evangel, which does not seek to rebuild the world, but simply takes it as it is and fills it with clear fire, adding to its rough vigor purity of motive. I do not sce how anyone who loves moonlight can be bad, or even 
morose and melancholy. Its light drowns all these in a deep sea of peace.

As the moon came up, gibbous and glowing, its beams seemed to skim into the darkness under the pines as a swallow flies, scaling along beneath the blackness of close-set plumes above, to light long aisles between the naked boles below. These that had been so invisible before that I had to find my way among them by the friendly leading of the path beneath my feet, now took on a radiance of their own. Green and brown no longer , they glowed with the witchery of the level light, their real colors only shining faintly through this transparent frosting, this veneer of cool fire, till the place was like those European salt caverns of which one reads where the dark roof is upheld by crystalline pillars that give ghostly reflections of the lights that the miners carry. Here, groping in the grotesque glow of their own lanterns might well come the gnomes of German tales although, so sweetly gentle is the light, I can think of them only as kindly goblins bent on quaint deeds of goodness.

Beyond the pines the path led me moonward through glades among deciduous trees, no doubt the abodes of elves. That may have been but a 


\section{II6 OLD PLYMOUTH TRAILS}

sphinx moth that flew down the path before me, his fat gray body silvered by the moonlight, his short, narrow wings beating so fast that they became but a gauzy nimbus about him, or it may have been Puck, training to put that girdle round about the earth in forty minutes. Here invisible creatures scurried away from a fairy ring whose flagging is of round pyrola leaves, lighted by ghostly white candelabras of the waxy blooms, field mice, very likely, or black beetles, or elves dancing in the moonlight about their queen. How am I to know which? Surely if elves dance anywhere it is on midsummer nights like this when the dew has clotted on all the leaves till they are pearled with a soft green fire as if from caverns under sea and I walk down the path through such caves and among such kelp and corals as a merman might. All about me I hear the stirring of the little people and now and then soft airs fanned from invisible wings touch my cheek. It may be moth, or bat, or tricksy Ariel for all I know or care, such glamour does the haunted air throw about him who will leave the brown earth behind and plunge in its silvery depths.

Pushing aside tapestries woven of such figures 


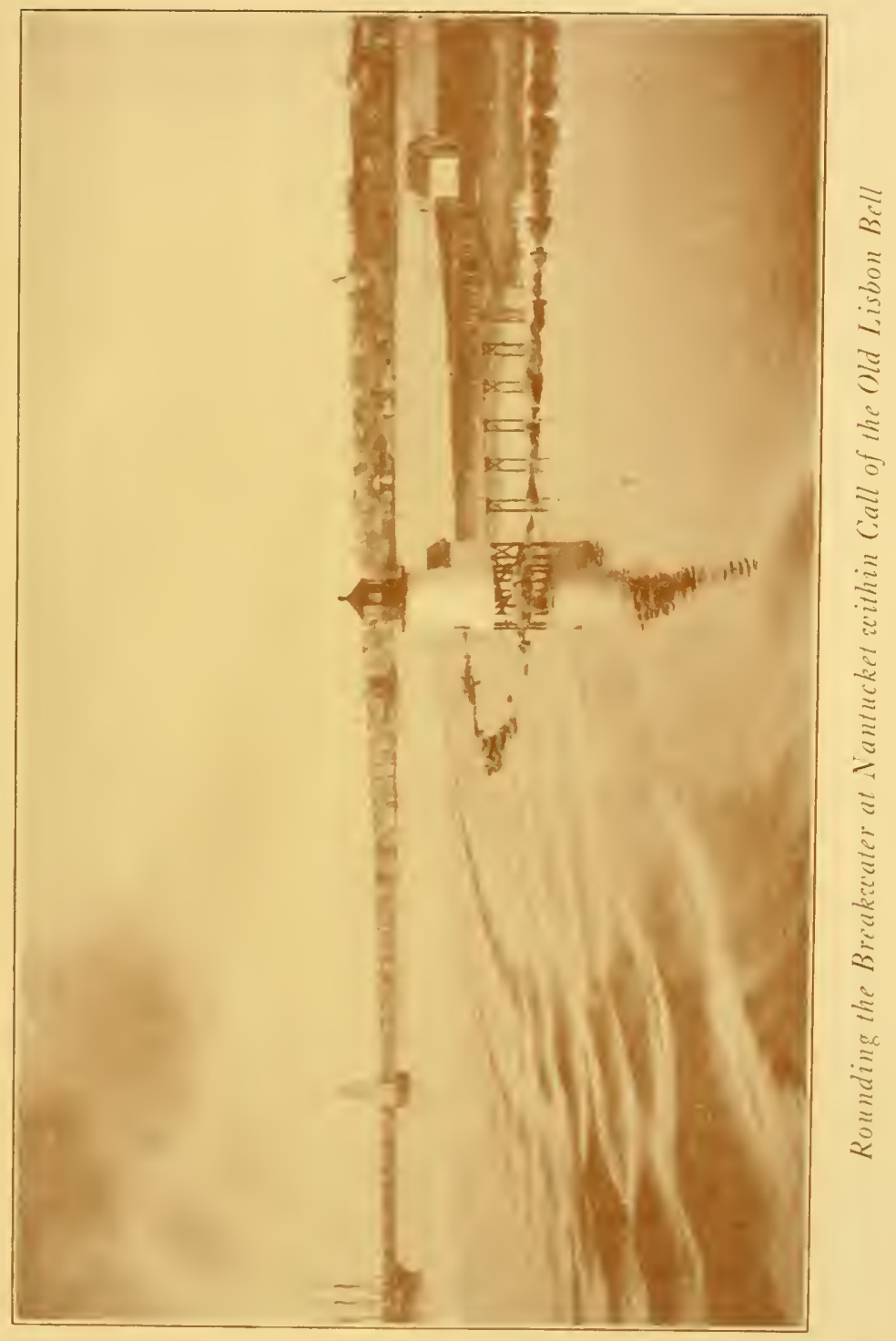


THE NEW YORK PUBLIC LIBRARY

ASTOR, LENOX

TILDEN FOUNDATIONS 
as these on a cloth of white silver, I stepped out of the wood on to the shore of the unruffled pond. Here a man might well pause and take no further step lest he fall into the blue depths of space. The moon hangs like a great shield in a sky of soft sapphire, piled with luminous figures. Within the wood are fairy and elf, goblin and gnome, half seen in the filmy light. Here giant genie stand revealed, passing in the dim perspective of mighty distances or leaning portentously from the radiant sky. In the mirrorlike pond I see all these things repeated in an underworld that is as distinct and clear, yet strangely distorted. The miles of soft blue distance that stretch invitingly upward to the withdrawn stars of the zenith, stretch as soft and blue, but fearsomely deep beneath my feet to the nadir. Standing at the water's rim I am on the verge of a vast, deep gulf that no plummet might fathom, into which at another step I shall begin to fall, and once falling fall forever, for there is no bottom. It is all very well to say to one's self that an inch below the mirroring surface lies the good gray sand which was there by daylight. The midsummer moon is past the full and things are as they seem. 


\section{OLD PLYMOUTH TRAILS}

By midnight the white genie of the sky had stalked off beyond the horizon out of sight. The moon that had been so great among them with its rim touching the eastern hills that it was like a great map of itself hung on the margining sky, had concentrated to a ball of white light near the zenith. Back in the wood I found the invisible little people out in full force, rustling, flitting and calling. But the white light had gone and under thick foliage of deciduous trees the real night had come again, dappled, indeed, by flecks of filtered moonlight which dazzled and made the shadows more obscure. In the depths of the pines the veritable darkness of Egypt smothered all sight. Here the path must be found by the feet alone, and it is singular what potency of understanding thrills up from the good brown earth through the boot-soles when it is needed. Every footpath is a shallow canal through which you flow as does water if you will but let it lead you. If the foot fall but a little to the right or left of the wonted spot some slight inequality of the earth that in the full daylight would never reach your senses, now sends definite messages to you. By it you swing with certainty to the right or the left and find the next footfall near enough within the nar- 
row way to continue the guidance. No matter how winding the path, it will keep you within its borders if you will but give up your will to it.

Stepping from this Egyptian shadow of the pines to the full glare of midnight on the brow of the hill was like having a searchlight thrown on you. All things gleamed in a white radiance which had rainbow margins where the dew hung heaviest on nearby objects.

By day in this spot the eye is photographic and records every detail, by night you have the same story told again by the brush of an impressionist. It is the reverse with sounds. In the full glare of the sun the myriad voices of the world mingle in a clear roar that is a steady musical note, and soon you forget to hear it. By night each noise is individual, and leaves its impress on the mind. Whoever remembers the quality of noises he hears by day in the city, however great the uproar? Who can forget the soothing chirp of crickets in the grass at his feet by night?

Standing on a hilltop on such a midnight a man may map the watercourses, large and small, for miles around, though by day he can see from the same place no glint of water. Here is a deep lake of white fog which marks a marsh, and into 


\section{I20 OLD PLYMOUTH TRAILS}

it flow winding streams that are level with the treetops on the margin. Here the moon by night is distilling and vatting mountain dew from which all wild creatures may drink deep without fear of deleterious effects. It is the cup that cheers and does not inebriate. The waking robins tipple on it and sing the more joyously, nor is there in their midday any of the moroseness of reaction.

Three hours later the moon had slipped down from the zenith into cushions of velvety, violet black, low in the western sky. Its bright white glow was lost in part and it was haloed with a yellow nimbus of its own fog distillation. Over on the margin of the pines the little screech owl, now full of field mice and having time to worry, voiced his trouble about it in little sorrowful whinnies. Down in the pasture a fox barked distinctly and a coon answered the plaint of the screech owl in a voice not unlike his. It always seems to me that the night hunters of pasture and woodland bewail the passing of such a night as much as I do. The whippoor-will began to voice his petulant wistfulness again. He had been silent for hours, feasting I dare say on myriad moths and unable to call with his mouth 
full. The whippoor-will chants matins as querulously as he does vespers. Far in the east the stars that had been gleaming brighter as the moon descended paled again. The night in all its perfect beauty was over, for into the shrill eagerness of the whippoor-will's call cut the joyous carol of a dawn-worshipping robin. 


\section{CHAPTER X}

\section{TURTLE-HEAD AND JEWEL-WEED}

In my town, summer, whom the almanack calmly orders out on August 3Ist, refuses to be evicted in person and lingers serenely while the furniture is being removed, often until late September. In these September days I think we love her best, perhaps because we know that soon we shall lose her, and already the parting has begun. It is not that certain flowers that came joyously in June are now but dry bracts and seed pods. She has given us other beauties and fragrance to take their places. It is rather that summer herself is gently breaking with us, giving us the full joy of her warmth through the day, but discreetly withdrawing at nightfall and lingering late in her own apartments of crisp mornings when there is a tonic as of frost in the air, whereby October woos us.

The garnishings of her house are hardly fewer while the moving van people are so busy, and I am apt to delight in them all up to the very mo- 


\section{TURTLE-HEAD AND JEWEL-WEED}

ment when the sweepers, the autumn winds, come and brusquely brush them out. Old man Barberry is very happy at this time too. Since he hung out his queer smelling pale gold pendants in late May he has shown no touch of color, but has wrapped himself stoically in sober green and waited, as old men know how to do. Now his day has come again and he is very brave in rubies that fringe his dull attire and make him flash fire in the sun from head to foot. Slender goldenrod girls and blue-eyed aster children, trooping along the fields and over the hills, holding up the train of summer as she walks so sedately, think him adorable. If summer stops but for a moment I see them slipping slyly into his arms, laying golden heads on his drab waistcoat and gazing with wonder-blue eyes at his coruscating gems. I think well of old man Barberry, too; better I fancy than he does of me. I admire his stocky growth which has a sturdy grace of its own, and I love him for the birds that he shelters, the yellow warblers that love to build their cottony nests in his arms. But he was born in the pasture long before I was and he usually resents my advances. His trident spines have a sarcastic touch that tingles, and with them he bids me 


\section{I24 OLD PLYMOUTH TRAILS}

keep my distance. But he is a wise old man in his love for gentle beauty and he makes a fine picture of gold and green, ruby fire and tender blue as he folds all these youngsters in his embrace. Those spines he must fold very close, even to the withdrawing of them into his orange colored cambium layers, for there is never an ouch from the group.

These are summer's flowers for remembrance, the goldenrod and asters. She gives them to us and goes, making all early autumn glow with her memory thereby. But old man Barberry may have these if he will. I like best to remember her by others less common and less permanent, flowers of shy dignity that begin to think of departure when summer'does, and vanish with the flash of her trailing garments. Two of these, the turtle-head and the jewel-weed, are little known to careless passers, and elderly pasture shrubs have no chance to lure them with Attleboro jewelry. They have their abode in cool springs in seclusion behind the pine-clad hillside, and would, I fancy, be ashamed to be seen wandering wantonly about the open fields. I have to make pilgrimage to their home in the middle of the fountain head marsh to meet them, nor are 
their real beauties revealed to one who carelessly splashes in. Instead, he is liable to be mired in black mud and see nothing so good as his way out again, nor will he even notice the elfin laughter of black crickets and green grasshoppers who rub their preposterously long hind legs together in glee at the joke, so eager will he be for dry land.

The right of way leads over a level, firm trunk of a fallen tree, one that has been so long down that only a mossy ridge indicates its existence, to a sphagnum mound which tops a stump as old as the causeway. A swamp maple grows at this stump as a back for my seat in this reception room of the jewel-weeds. I think it is the sway of the slender maple that puts me in rhythm with the mood of the place and gives me eyes to see things as they are, for after a little the rough swamp snarl of straggling growth unravels itself, and things stand revealed.

There is the rough bedstraw. Somebody who saw it first shall burn for calling such a sweet little plant such a mischancy name. I protest that the bedstraw is worthy a better. To be sure it is rough. The prickles that line the edges of its stems all point back, and while they do not wound they hold you tenaciously when you touch 


\section{I26 OLD PLYMOUTH TRAILS}

them. Thus the plant clings to other woodier stems and climbs vicariously. But why bedstraw?' I trust that none of the people who came out of the ark and set about naming things as they followed had to make bedding of these rough stems. With the whorls of slim green leaves that climb with the slender stalks the plants make lace and a green mist all about, underfoot in the marsh, lace that drapes tall plants to which it clings, a green mist out of which shine constellations of tiny star blooms. Picking these constellations to pieces one might place a hundred of the tiny, four-pointed stars on a copper cent and never overlap the petals, yet they shine above the green as Orion and Cassiopæa do over the frost fog of a winter night, they are so vividly white.

I never see this at first. It is only after the tranquillity of the place has shrunk my unwieldy bulk to the patient potency of the tiny herbs themselves that I have the sight. It is admirable, this potent patience of these wee things that are born in bogs yet in their own world grow stars the memory of which lasts as long in the consciousness of man as does that of the Pleiades. If you pluck them you will see by turning them 


\section{TURTLE-HEAD AND JEWEL-WEED}

over that these constellations are as whitely bright to small eyes that look from below, from the ooze of the bog or the roots of marsh grass, as they are to our great eyes that look from above. Of an early September morning in the clear stillness I feel that they loom like varnished planets of the sky in their own lowly heaven of coruscating dew that coats all things with a milky way of white fire drops, a dew that has risen all night from the warmth below and, chilled by the cold blue void of space, has hesitated on every leaf and twig, frightened into immobility; infinitesimal drops as shining white and as close together as the stars in a winter night sky. At dawn all the bog world is crusted with this dew.

A great gravelly hill rises abruptly from the southern edge of this boggy home of shy plants, clothed with century old pines. These are so high and so dense that the sun's rays cannot come through with any directness, instead they are so filtered and reflected from gloss of leaf and gray of trunk that they have no power to dry up this dew, they simply light it up, nor can the little morning winds that play at surf bathing in the pine tops, dancing hand in hand, ducking with 
little shouts of laughter and singing songs learned from the roar of breakers on gray rocks, come down to drink them up; so the stars of this under-forest heaven remain to keep the bedstraw constellations company until nearly noon. By way of the lower heaven of bedstraw blooms the eye rises easily to the forest of jewel-weeds. These at least are rightly, if unconsciously, named. It is not only the bloom but the whole weed that is a jewel when the morning sun is low and the reflected light slides level into the forest among purple stems that shoal into transparent green as they slender toward the leaves. These, too, seem transluscent and glow, and then some sprite seems to have suddenly turned on the jewels. Strange that they did not flash to my eyes even before I came to the place, on my way down the hill. Perhaps it is some trick of light and shade that makes them flash on at a certain time and glow like transparent gold shot through with light. No jeweller could make these: they are such as a fairy prince might hang on the pale green breast of a dryad, a nuptial gift of surpassing value out of fairy coffers.

At the thought I see more clearly still and each plant becomes a slender personality of the forest, 
a nymph whose purple life-blood runs clear in delicate veins under a skin of transluscent green. Out of what trees they stepped seems not difficult to tell. Surely this one came down out of a pasture elm to bathe slim feet in the cool spring water. Here are smaller, more slender creatures that came from white birches, and that group of stately ones stepped out of the tall white pines that stand on the slope nearby. No wonder the other creatures of the glade adore these slim green dryads of the swamp. The misty green bedstraw fawns about their feet and makes lace for their gowns. The polygonum blushes pink and stretches long arms toward them. The white alders, to whose tips beauty and fragrance still cling bend over them and toss white petals and perfume their way, while even the homely bur-marigold seems to glow a little better yellow in fondness, though it very properly keeps its distance. Rough rushes nod three-cornered approval and I am sure the spinulose wood ferns crowd down into wetter spots than anywhere else, just to get sight of them. In fact they stand in such wet ground that you might think them Nephrodium cristatum instead of Nephrodium spinulosum were it not for the delicate fringing 


\section{I30 OLD PLYMOUTH TRAILS}

of their fronds which no other fern can equal.

While these things happen I think I can see the dryads quiver with delight and their jewels dance and flash, living creatures rather than gems. Surely if anyone may wear living jewels it should be dryads. They have a trick of facing you, these jewels, and looking like golden butterflies just spreading petal wings for a flight. At such times I am minded not to move suddenly lest they go off over the treetops like a flock of goldfinches. If they should I should not be surprised. With a change of light or position they change appearance again and become tiny gold dragons, winged dragons with gaping mouths and little keen brown eyes that size you up. Again each is but an ear-pendant, beaten of thin gold hanging beneath the shell-green ear of the dryad.

All these are early morning fancies, born, I dare say, of the fine flavor of the place, drunk in dew. At noon, when the sun shines direct into the marshy glade, the dryads have gone back into their trees for a noonday nap and the jewelweeds are but weeds after all, though beautiful ones. Bees come sailing along and plunge at the open cornucopia of the lower petal, which was 


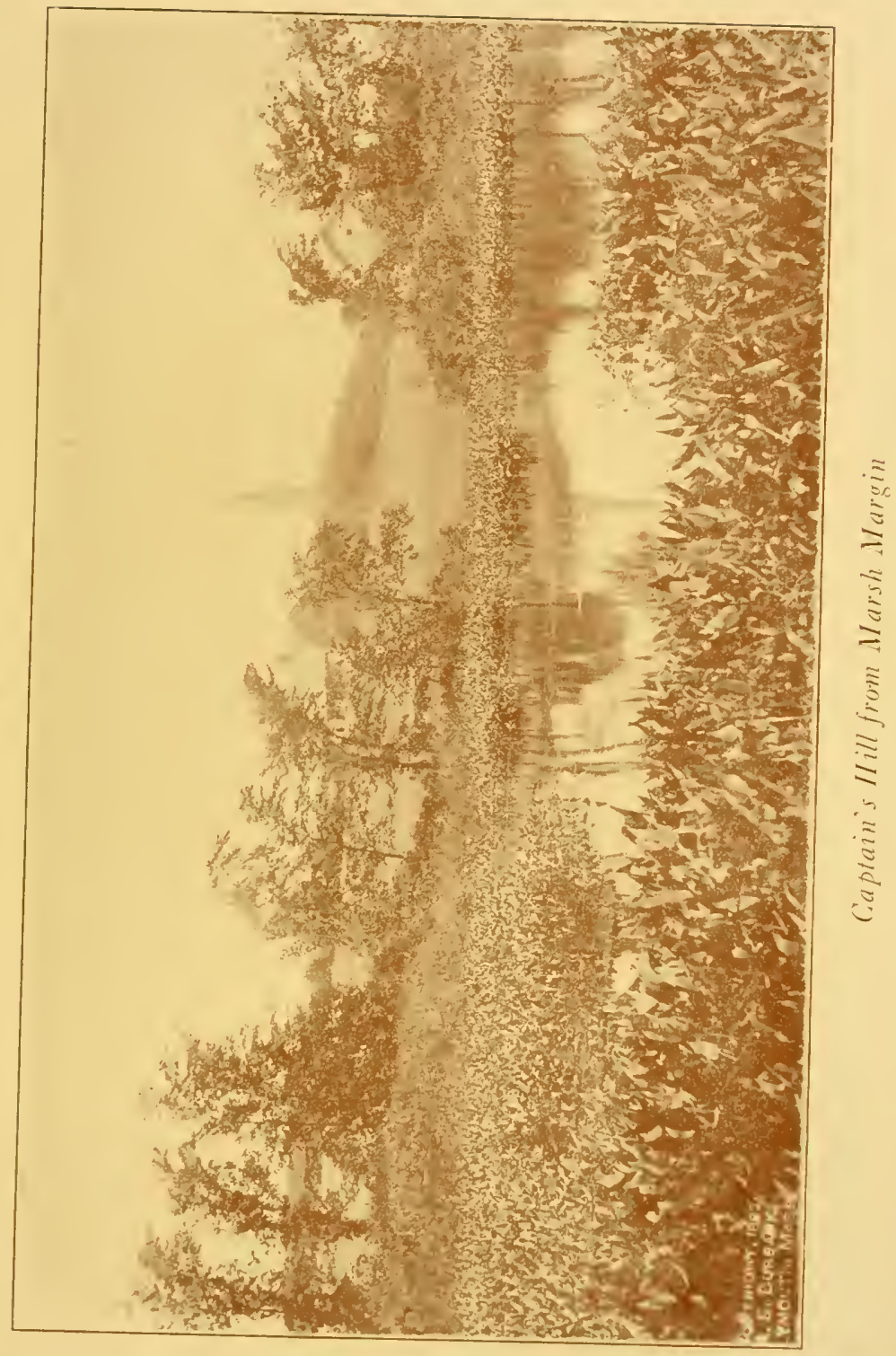




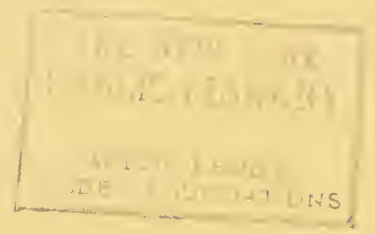

\section{-}


the very dragon's mouth, after the honey in its tip. Honey bees would find ready entrance, but the burly bumblebees are far too fat. These light on the lip, through inherited habit, no doubt, but immediately turn to the recurved honeyholding tip and plunge the proboscis through its slender texture, stealing the honey from flower after flower. In a day's watching I have seen only bumblebees gathering honey from these flowers, and I wonder about the fertilization which certainly requires that insects should go in and out at that open dragon mouth, not little chaps, but buzzy, fuzzy creatures that will brush off the pollen and carry it.

I have no doubt about the bumblebees and the turtle-heads. Each vivid white corolla of the groups that stand so stiffly on the ends of the long stalks seems especially made for a bumblebee. He goes into it as a hand into a glove, flattening himself amazingly for the entrance, but finding room to work in the interior, though not enough to turn about in. On his way in, what pollen he already may have collected on his furry back slips easily off on the very lip of the stigma which waits at the strategic point with the antlers crowding well forward, but firmly held a 
hair's breadth behind it. Thus each bloom is fertilized with the pollen from some other, insuring cross-fertilization. The bumblebee takes his toll in honey, but when he comes to back out he has trouble. If you will listen close by you will hear him buzzing and burbling like an overheated teakettle as he struggles. The arching filaments of those fuzzy stamins have tangled his short legs and he is shaking the pollen out of the antlers all into the fur of his yellow overcoat. Before he gets out he is right mad and loaded with pollen for the fertilization of the next bloom. He comes squeezing out, as flat as a pancake, sharp end first, and though I watch close by I am very respectfully motionless. But he gets all over it by the time he has flown to the next bloom and his hum as he prods his way in has the tone of a cheerful "Good morning."

The turtle-heads have none of the frail loveliness of the jewel-weeds that suggest half-visible dryads, but they have a stanch beauty of their own which I think makes them seem very comely. Each corolla is a smooth, opaque white through which no light may pass. It is easy to know how it looks inside a jewel of the jewel-weed. From without the imagination can appreciate 
that glow of pale gold which must there suffuse all things. To such tiny midges and beetles, spiders and moths as may enter it must be like walking about in the heart of the Tiffany yellow diamond. The bumblebee might tell how it seems in the turtlehead petal, if he knows. I fancy, however, he is so everlastingly busy and so mad with the filaments when he is inside that he has no time to think of atmosphere. Often the pure white of this flower is tinged with a soft shading of delicate rose near the tip of the petal. It is an unobtrusive shading, as shy as the bloom itself. Ashes of roses might describe the tint better, for it is as gentle as the fading pink of a sunset sky, a shade that has dropped thence to the lips of these blossoms hiding in the dusk of the swamp. You see it best by looking close into the very face of the flower as the bumblebee does when about to alight on it, and I think it is set there to show him the way. By the time he has seen that, he is near enough to be drawn by the faint but ravishing perfume which is breathed out by the flower. It is so faint that you must come like the bee to the very lip of the corolla before you will find it. It is so tender and of such refinement that when once you get it you will 


\section{I34 OLD PLYMOUTH TRAILS}

think no blossom has its equal. The white alder at this time of year is prodigal of rich and delectable odors. The jewel-weed with all its beauty has none that my sense can perceive. But that of Chelone glabra, as modest and withdrawn as the flower itself, seems hardly to belong in the swamp for all the beauty of the place. It should rather be that of some delicately nurtured plant, some rare orchid of sheltered conservatories, it is so delicate and delightful.

The jewel-weed is as frail as a dream for all its vigorous growth which reaches sometimes six feet. If you pluck it it withers before you can get it home to put in water and its jewels shrivel to nothing on the way. Turtle-head is far different and I like it for its sturdiness, but most of all I like it because it is the host of a small friend of mine, the Baltimore butterfly. In summer you may see this little fellow, a plaid of yellow and orange on black, the Baltimore colors, whence his name, flitting about, never far from the place where the turtle-head grows. If you see one you may be almost sure that the other is nearby. I have not seen the butterfly for many weeks, but among the stalks of Chelone I find the webs which shelter its children. These tiny 


\section{TURTLE-HEAD AND JEWEL-WEED I35}

caterpillars will feed on the leaves till winter, then by some witchery of nature survive the frost and snow and zero weather, sheltered only by this filmy, flimsy home, finish their growth in the spring, waxing fat on the young leaves and by late May be floating about, more Baltimore butterflies.

There can be no better evidence of the witchery and romance of the place than this, that these frail pulpy creatures should with no covering worth the name withstand cold that under similar conditions would kill me before Christmas time. When I think of this dreams of dryads that troop down from the hillsides and stand, slender and adorable jewel-weeds, where the cool springs ooze from beneath the gravelly hill, do not seem in the least absurd or improbable. 


\section{CHAPTER XI}

\section{THE WAY OF A WOODCHUCK}

The memory of my first glimpse of a woodchuck always reminds me of an old story which needs to be retold that it may point my moral even though it does not adorn my tale.

A minister, supplying for a time in a country parish, took a pleasant path through the fields to the church of a Sunday morning just before the service. There he found a boy digging most furiously in the sandy ground.

"My lad," said the minister, in kindly reproof, "you ought not to do this on Sunday morning unless it is a labor of necessity."

"I don't know nuthin' about necessity," replied the boy without stopping for a moment, "but I've got to get this woodchuck. The minister's comin' to dinner."

Nobody has ever told whether the boy-and after him the minister-got the woodchuck or not, but there is at least an even chance that he did not, for a woodchuck in saridy ground will move 


\section{THE WAY OF A WOODCHUCK I37}

on into it, taking his hole with him, at a rate that has defied more than one industrious pursuer. Just how he breathes while this is going on is more than I know, for he fills the passage behind him with the débris of his digging, but he evidently does find air enough, for after tiring out the excavating hunter and waiting a reasonable time he digs up and out and proceeds to the deglutition of kitchen gardens with an artistic thoroughness that has been his since days of the Pilgrim Fathers, and I will not undertake to say how long before that. I do not doubt that the first Indian that ever planted corn and beans and "iskooter-squashes" said the same things about the woodchuck that I do, in his own language; and I believe that the woodchuck then, as he does now, just wrinkled his stubby black nose and retired to his burrow to sleep upon it while the garden digested.

No one to look casually at the woodchuck would think he was hard to get, but he is. The first time I ever glimpsed one I learned that. The woodchuck was eating second-crop clover in a hayfield that had been mown about three weeks before. A little cocker spaniel and I were strolling in the field when suddenly we heard a squeal 


\section{I38 OLD PLYMOUTH TRAILS}

that was shrill enough to be a whistle and a fuzzy brown blur streaked for the stone wall, followed by another. The cocker spaniel had decided, like that boy, that he had got to get the woodchuck. I fancy he thought he had him when they came together about five feet outside the crevice in the wall for which the woodchuck had made his fuzzy bee line, but as a matter of fact the woodchuck got the first grip. His long yellow incisors met in the cocker's shoulder and that worthy gave forth a yelp of pain and indignation as the battle began with that strange hold.

I wish I might describe the Homeric conflict that followed, but it was too full of action for anyone to grasp the details. A furry pinwheel revolved in varying planes, smearing the stubble with gore and filling the air with cries of mingled pain and defiance, for what seemed to an astounded and perturbed small boy a good part of the afternoon. Most of the gore and all the cries came from the dog, for the woodchuck fought in grim silence, though no whit more pluckily than his opponent. In the end the dog won, but he was the most devastated small dog that I have ever seen, before or since, and had it not been for prompt surgical aid at his home 
nearby I dare say Charon might have ferried both shades over the Styx together. No, the woodchuck is not so easy to get. He is quite likely to whip his own weight in most anything that forces him to do battle.

But I have never known a woodchuck to do battle that was not forced upon him. In point of fact he is one of the most home-loving, peaceful animals I have known. He is the original home-body and if the market where he is forced to seek supplies is not near enough to his home he moves the home nearer the market. In that often lies his undoing. His safety is in the woodland border or in the far pasture stone wall. There if he would content himself with aromatic barks and wild pasture herbs he might dwell unharmed of man, who is his chief enemy. But he loves the clover field, and often his first move toward disaster is coming up from the pasture wall and digging a burrow in the midst of the clover where he soon has regular paths which take him from one rich clump to another. After that he sniffs the kitchen garden, and the descent to Avernus is easy. He moves in to the borders, finds a crevice or digs a hole, and revels. Nor does he recognize the place as Avernus-which it 
is bound to be sooner or later-but spells it Olympus in very truth. Man may be the devastator of the earth, and he certainly is so far as its wild life is concerned, but as a producer of succulence in the kitchen garden he is a deity before whom any woodchuck must fall down and worship.

For the woodchuck besides being the original home-body is without doubt one of the founders of vegetarianism. Born in the desert places, feeding on locust bark and wild honeysuckle, he added inches to his girth when he learned that red clover which the early settlers kindly brought with them had a nourishing quality that defies competition. A woodchuck can get so fat on clover that by November, when he retires for the year, he is as near a complete globe as anything with feet and a face can ever be. The convexity begins at his eyebrows above, at his chin beneath, and though he has feet, they have the effect of being merely pinned on to the lower hem of his garment, as those of a proper young lady in our grandmother's day were supposed to be. The woodchuck can get no fatter than that on garden truck, but he likes it better. I doubt if Charles Dickens ever saw the animal, but when he created 


\section{THE WAY OF A WOODCHUCK I4I}

Mr. Wardle's fat boy he might 'well have taken him for a model. "D—n that boy," says Mr. Wardle, "he's asleep again." That was when he had ceased eating, and so it is with the woodchuck. In the early dawn when the dew is on the lettuce, he takes his toll of the bed, seasoning it with a radish and a snip at a leaf or two from the herb bed. But such are mere appetizers for the feast. The next course is the peas. He can go down a row of peas that are about to set their flat pods swelling to become fat pods and eliminate everything but a stubble of tough butts that have been shorn of their ladylike and smiling greenness. Pea vines in the garden always seem such gentle ladies, clad in a fabric of soft, semitransparent green, nodding and smiling, slender, tall and sweet. But when the woodchuck romps back up the row nothing is to be seen but the smile.

They returned from the ride

With the lady inside,

And the smile on the face of the tiger.

I once heard a vigorous discussion amongst men who know the woods and the ways of wild creatures, as to whether or not a woodchuck can climb a tree. The discussion ended rather 
abruptly when one of the party produced a photograph of a woodchuck a dozen feet up a big pine sitting on a small stub of a limb, looking somewhat exultant but also as if he wondered not only how he got so high but how on earth he was ever to geit down again. I myself would not have believed a woodchuck could climb a tree of that size if I had not seen the photograph, and I fear there are some doubters in the party to this day. But whether or not a woodchuck can climb a big pine he can go up a bean pole as far as a bean vine can climb, and return with the bean vine inside. It takes but a few mornings for a woodchuck who means to keep fat enough not to shame his tribe to send a fleet of beans, that but now had everything set in living green from main truck to keelson, scudding down the garden under bare poles, a melancholy sight to the amateur truck farm navigator. On peas and beans the woodchuck holds his own, and he reckons as his own all that the garden contains. For all that you find frequently one that has a special taste. My last year's most intimate woodchuck climbed the bean poles and romped the rows of early peas as I have described. These were his occupation, his day's work, so to speak, and he 


\section{THE WAY OF A WOODCHUCK I43}

went at them at the first blink of dawn and got them off his mind. Then he retired to his burrow just on the corner of the garden before either the sun or I got up, and slept the dreamless sleep of one who has labored righteously and fed well. I suspect him of letting out his belt a hole a day on this plethora of protein that I had been coaxing up the bean poles all the spring.

After that for the balance of the day Mr. Woodchuck was a dilettante, sitting at his door in the sun and dreaming dreams of artistic elegance in horticulture. I used to see him there about IO A. M., wrinkling his forehead in the perplexity of artistic temperament, batting a speculative eye at me meanwhile, but not in any spirit of resentment. In fact, he had nothing to resent. He had absorbed the unearned increment and I had my original capital, the bean poles, intact-and that's more than most of us realize on small investments, nowadays. So I dare say he thought I had nothing to feel grieved about. Later he would sally forth and carry out his artistic dreams on my Hubbard squashes. I have never had Hubbard squashes pruned into such artistic shapes as that year. The squash vine is a great stragger if left to its own devices. 


\section{OLD PLYMOUTH TRAILS}

It will start from the corn hill where it is produced and go down the row fifteen feet, then climb a corn stalk, leap to the fence six feet away and eventually hang a row of Hubbard squashes around a neighbor's pet pear tree. The woodchuck stopped all that. He began early in the summer on the vine tips and worked inward well up to the stump at each meal. The vines were husky and had more latent buds than I had believed possible. Every time the woodchuck cut them back they started something in a new place for his incisive pruning shears. Some people trim evergreens on their lawns into grotesque shapes. My woodchuck invented that sort of thing all over again on Hubbard squash vines. After some weeks I had a new and strange race of decorative plants that, like $\mathrm{Ka}$ tisha's left elbow, people came miles to see. But they did not produce squashes. Dilettantism doesn't.

In the end, of course, like the small boy at whose house the minister was to take dinner, I had to get the woodchuck, after which the garden was more productive if not so picturesque and romantic. 


\section{THE WAY OF A WOODCHUCK I45}

The full-grown woodchuck rarely leaves the burrow except to forage. That done he spends some time usually just at the entrance sunning himself. But most of the time, day and night, he is within, presumably asleep half the summer long. The young woodchucks at this time of year are more often seen abroad, for the parents send them forth upon the world to earn their own living at a rather tender age. They roam the fields and thickets and do not seem especially afraid of man, scuttling into the underbrush perhaps with their whistling squeal, but just as likely to sit back on their haunches and offer to fight. The mortality among them at this time must be great. Foxes pick them up and feed them to their own young. Hawks and owls do the same and dogs find them an easy prey. But enough get by such dangers to dig burrows in the fall and next spring move up to somebody's garden patch, there to absorb feasts and defy fates until the outraged householder stalks forth and deals death amid the ruins of his hopes. The woodchuck sitting by his burrow in the far pasture is a friendly little chap, whom I wish well. I would not harm a hair of him. But the woodchuck that 


\section{I46 OLD PLYMOUTH TRAILS}

has adopted suburban life is a menace of whom I am forced to say in the words of Cato of old "Delenda est Carthago."

The forefathers found the woodchuck here, probably in the first spring garden which they planted over the graves of the dead in Plymouth, saw how much he had eaten and promptly named him, his name meaning "little pig of the woods." Chuck or chuckie is a word of their time, and I dare say now, meaning "little pig." The idea is again expressed in the rather less polite form of "ground hog" and the hereabouts at least, little known "Maryland marmot" is a third. Scientifically he is known as Arctomys monax, being a rodent and classed with the marmots, very close relatives of the squirrels. Perhaps it is through this family affinity that he is able to climb my bean poles.

The woodchuck has one other distinguishing characteristic which deserves reference, that is his ability as a sleeper. As a home body he is great. As an absorber of garden truck he is greater. But when the sun of October swings low in the south and he has become so fat that he seems to roll to and from his burrow on castors is when he shows his most surprising char- 


\section{THE WAY OF A WOODCHUCK}

acteristic. Mr. Wardle's fat boy with all his fame never slept as the woodchuck then prepares to sleep, however well he matched his eating. The first chill wind sets him to dragging dry leaves and grass down into the snuggest chamber of his burrow and there a little later he tucks his nose in between his little black-gloved forepaws and goes to sleep. When the woodchuck is leaner he goes to sleep by drowsily sitting upright, his head drooping lower and lower until he finally rolls into a round ball and falls on his side. But in late October the woodchuck is so nearly round with obesity that he cannot roll up and I fancy him just withdrawing his nose and his toes a little farther into himself, and going to sleep in that attitude with a sigh of content. The woodchuck's chief fame seems to rest on this trait, his ability to go to sleep before cold weather and not wake up again until the spring has again brought out the green things for his delectation. To be sure tradition has it that the ground hog comes to the mouth of his burrow on Candlemas Day and looks for his shadow that he may figure out how much longer he may sleep. But that I take to be a mere literary furnishing, like the chuck part of the animal's name, brought from 


\section{I48 OLD PLYMOUTH TRAILS}

England with the pioneers and adapted to use in this country. Probably it is said in England of the dormouse, which also sleeps winters, as does the woodchuck, though I believe lightly compared with our animal. The woodchuck is far too sound a sleeper to wake up on a February day, whatever the inducements.

That matter is no more to be taken seriously than is the old-time Yankee query -

How much wood would a woodchuck chuck, If a woodchuck would chuck wood?

which seems to me to emphasize the whole popular conception of the animal. Of all the common New England animals he is the one taken least seriously. Even if he does eat up all our summer garden we are apt to grin as we bear it; or if we do go out and "get" him, we do it with a forgiving, pitying smile. 


\section{CHAPTER XII}

\section{ALONG THE SALT MARSHES}

When the wind is east Sumner's Islands seems to tug at its moorings like a cruiser swinging at a short hawser in the shelter of Stony beach. If you will stand on the tip of its gray rock prow and face the sea it is hard not to feel the rise and fall of surges under you, and in fancy you have one ear cocked for the boatswain's whistle and the call to the watch to bear a hand and get the anchor aboard. Just a moment and you will feel the pulse of the screw, hear the clink-clank of shovels and slice-bars tinkling faintly up the ventilator; one bell will sound in the engine room and under slowest speed she will fall away from the sheltering beach, round the fragrant greenery of the Glades rocks and, free from their buttressing, prance exultantly to four bells and a jingle out into the surgent tumult of the roaring sea. Wow! but the fancy sets your blood to bubbling and your pulse to swinging in rhythm with the long surges that leap about Minot's and froth 
white over Chest ledge and the Willies, that come on to drown the inner Osher rocks in exultant whirlpools and fluff the loose stones of the beach into a foam that ripples over the breakwater into the road that snuggles behind it.

But that is when the wind is east and really blows, when November has stripped the oak and hickory upper works of the cruiser bare of leaves and she stands grim in her gray war-paint, ready for the winter's battles. Now she is gay in summer greenery and many a string of flower signals flutters from mast head and signal yard. You must go astern to get the wind in your face, for now it sings gently in from the west across a mile of salt marsh, pools of imprisoned tide where night-herons feed and tiny crabs and cobblers scurry to shelter beneath the mud at the jar of your footfall, winding creeks that twice a day brim with silver water, and levels of quivering marsh grass, to Cohasset harbor and the green hillsides of the Jerusalem road.

The island is an island by courtesy only at this time of year, aground in the green marsh. The bashful tides of summer yearn shyly toward it, and twice every twenty-four hours stretch soft white arms up the creeks from Cohasset harbor 
to the east and the west and fondle it. They hold it close at the hour of flood, but hand does not clasp hand about it, and the dry sand that links it to the beach and the breakwater is not wet. When the autumn winds shall come and the sea shakes itself out of its summer lethargy and asserts its power and will not be denied, it is different. At such times it roars over the beach and the breakwater and drowns the white sands that have kept the hands of its summer tides apart. It marches deep green up Cohasset harbor and brims the slender creeks. It passes their limits at a leap, and swirls in defiant, dogged depths over the drowned marshes. Then the island is an island in very truth, and the sea takes his love upon his broad bosom and rocks it, not always so tenderly. No man can guess the power of the floods and the deep sea currents herded by an easterly gale till he has seen the leaping of the flood tide at such a time.

Now it is a time of July gentleness and fripperies of color. The salt marsh, to be sure, never lacks these, even in the dead of winter, when high tides continually load it with sea ice, and then receding leave it piled with fantastic hummocks and pressure ridges like the Arctic 


\section{I52 OLD PLYMOUTH TRAILS}

sea. It has gleams of emerald and azure welling from its hummocks under gray skies. The tattered crimson of windy sunsets gets tangled in its floes and flutters in ragged beauty, and it treasures the sun's gold in the dusk of still evenings. Spring tints it with soft graygreens and autumn seems to use it for a mixing pot for the coloring of the October woods. All their flame and gold are there, toned to soft warm browns and tender olives just flecked with crimson and with yellow flame.

Looking westward from the island at high tide this morning you could see already deep hints of this coming autumn coloring, swelling out of the deep green of grasses that make up the main carpeting of the marsh, touches of brown and olive that are singularly pleasing to the eye under the summer blue of the sky and its fleecy flecking of white clouds. Amid these, scattered here and there, round eye-like pools reflect this summer blue and fleecy whiteness and all along the island's verge and that of other islands and the borders of the Glades was the pink of wild roses and morning glories, both of which seem to thrive better and bloom later in the season here than inland. But the softest and loveliest coloring 
ALONG THE SALT MARSHES I53

that the marsh will ever get is that which the gray mists of early morning seem to have brought in and left like a fragrant memory of themselves, the lavender gray of the marsh-rosemary. "There's rosemary; that's for remembrance," said Ophelia, and many a lover of sea and marsh-side will carry longest in memory the gentle sadness that the tint of the sea-lavender gives the marsh when all its other colors are still those of the flush joy of summer. Remembering Ophelia, marsh-rosemary seems its best name, though you have a right to sea-lavender if you wish. If the sea fogs did not bring it as an essence of the first glimpse of dawn in gray ocean spaces, then I am convinced that the loving tides bear it as a gift to the island and scatter it shyly at its feet, after dark.

You have but to wander about the shores of the island at the marsh line to find strange evidence of this gift-bearing propensity of the shy tides. Trinkets of all sorts that they gather in travels in distant seas the tides bring and lay lovingly at the roots of black oak and sweet gum, hickory and stag-horn sumac. Here is bamboo that for all I know grew near the head waters of the Orinoco, though it may have sprouted in the 


\section{I54 OLD PLYMOUTH TRAILS}

Bahamas, floated north by the Gulf Stream, shunted from its warm edge into the chill of the Labrador current and drawn thence by the Cohasset tides. Beside this lies a cask ripped from the deck of a Gloucester fishing schooner that sought the halibut even on the chill banks that lie just south of the point of Greenland. And so they come, chips from a Maine shipyard, wreckage from a Bermuda reef, and a thousand tiny things picked up at points between.

But the tides bring to the marsh and the island in it, to all shores that they touch here on our Atlantic seaboard, more than this. They bear deep in their emerald hearts, generated in their cool, clear depths, a rich vivific principle that bears vigor to all that they touch and sends rich emanations forth on the air beyond. Today on the inland hills and landbound pastures the sun beat in sullen insolence and the wind from the west scorched and wilted the life in all things. The same wind, coming to me across two miles of salt marsh, had in its cool, salty aroma a lifegiving principle that set the pulse to bounding and renewed vigor. It had gathered up from the marsh this tonic of the tides, this elixir vitæ which all the doctors of the world have sought 


\section{ALONG THE SALT MARSHES I 55}

in vain. Some day some one of them, wiser than the rest, will distil its potency from the cool salt of sea tides, and humanity, poor hitherto, will find itself rich in possibilities of physical immortality. Sea captains have a foolish custom of settling down at eighty to enjoy life on shore, else there is no knowing how long they would live. They have breathed the aroma of this lifegiving essence all their lives.

Yet the sea itself is dead; it is a vast accumulation of the product of complete combustion, hydrogen burnt out. But just as dead worlds, which are the molecules of infinite space, shocking together, burst into spiral nebulæ of flame which are the beginnings of live suns and planets and all luxuriant life thereon, so it seems as if the atoms of sea water, ever rushing to restless collision, burst continually into renewed life. All forms are in it, from the mightiest mammals to the protozoa which the microscope suspects rather than surely discovers. Every time molecule touches molecule in the depths, a new spark of tiny life must flare up, else never so many could inhabit the water. The coarser aggregations of these we see in bewildering profusion and variety every time the tides fall back and 


\section{I56 OLD PLYMOUTH TRAILS}

leave the rocks bare. At the bottom of the ebb I like to climb perilously down the rough Glades cliffs to life-brooding pools and inlets, where lazy waves swirl or are for a brief hour cut off. At the half-tide line the rock that is a reddish granite becomes chalky white with the shells of barnacles that cover every inch of space from there down. Acorn-like, they cluster closer than ever acorns did on the most prolific oak. After the tides reach them as they rise, the whole surface of the rock must be fuzzy with their curved cirri of tongues which protrude and lap the rising waves. Their number is legion, yet how infinite must be the fine floating life, so fine that we cannot note that it clouds the limpid water, on which these sessile gray creatures feed.

Below a certain level these are crowded out by the mussels which grow in such dense accumulations that they cling not only to the rock but to one another and to stubby brown seaweed till they are like nothing so much as pods of bees swarming about their queen. So dense is this grouping of living creatures that the inner ones are smothered by their crowding fellows and serve merely as a foundation on which these build. Even among these swarm starfishes and 


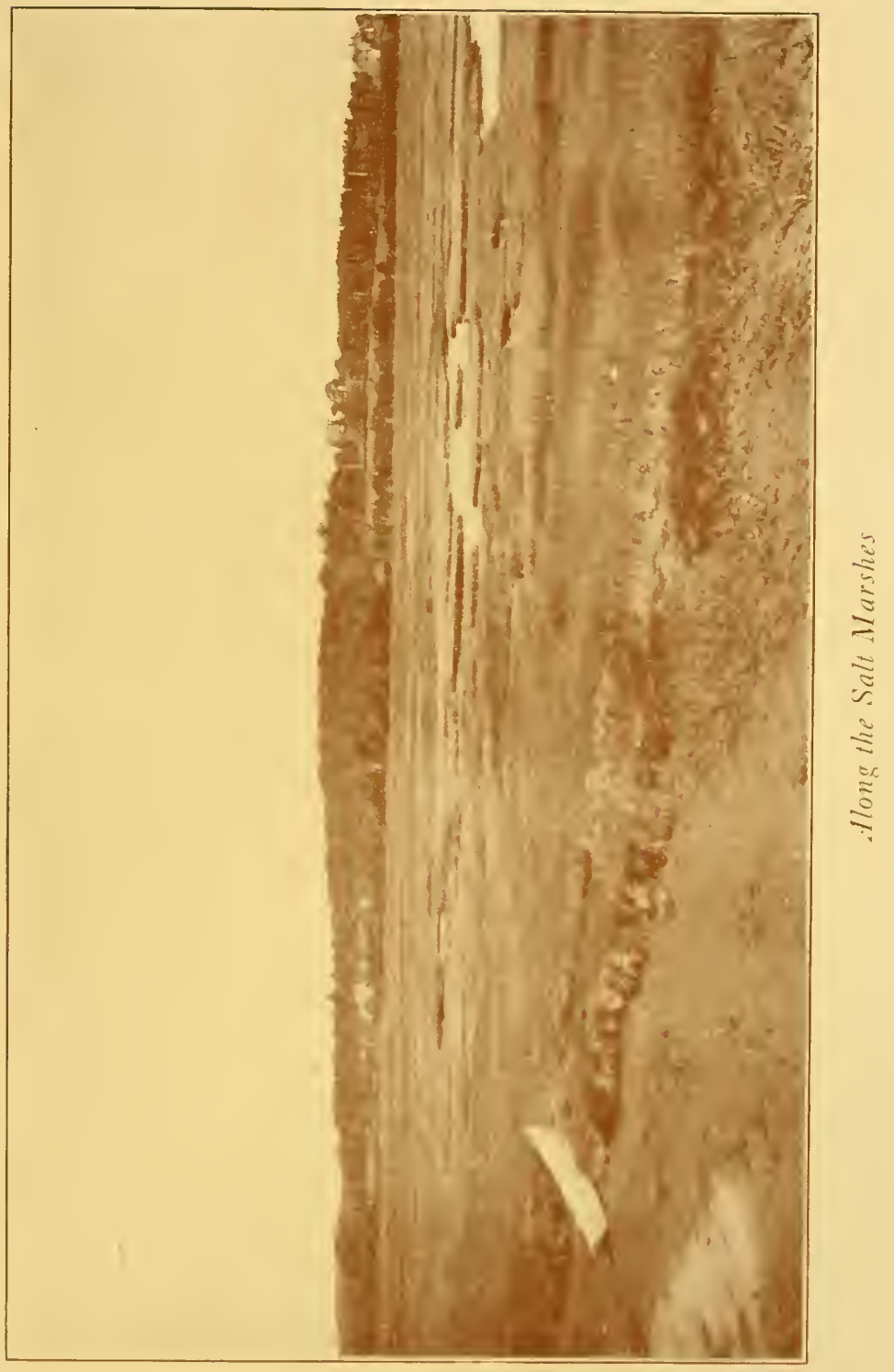




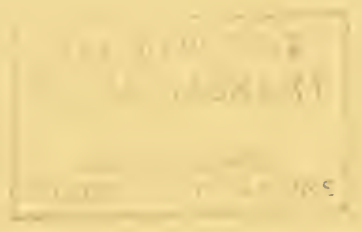




\section{ALONG THE SALT MARSHES I57}

limpets and other crustaceans, and streamers of kelp squirm out from the rock where they keep slender hold, to sway in the restless water, just as all the rocks above a certain depth and below a certain height are olive black with dense hangings of rockweed while in depths that are just awash at low tide they are olive brown with unending mats of Irish moss. These are but the forms of overwhelming life that meet the eye on first descending into the cool depths. To name all that may be noted in just the pause of a single ebb would be to become a catalogue.

Yet howsoever vivid the life or astounding by its multiplicity it is not impressions of these that linger long after one has come up from the bottom of the ebb. It is rather that here one has breathed the air of the deep life laboratory of the world, that into his lungs and pores and all through his marrow has thrilled a breath of that subtle essence, that life renewing principle which Fernando de Soto sought in the fountain of youth which he thought bubbled from Florida sands but which in reality foamed beneath his furrowing keel as he ploughed the sea in search of it. It is the same thrill which the wilting west wind steeps from the salt marsh as it comes across, 
some baffling and alluring ether distilled from under-sea caverns where cool green mermen tend emerald fires. The scent of it levitates from the wash of every wave and if you will watch with pure eyes and clear sight you may of moonlight nights see white-bodied mermaids flashing through the combers to drink of it. No wonder these are immortal.

Nor can you take from the things of the sea this life-giving essence, once they have attained it through growth during immersion in its depths, though perchance, as Emerson sang, "they leît their beauty on the shore, with the sun and the sand and the wild uproar." The shell on the mantel shelf of the mariner's inland home may be unsightly and out of place. But put your ear to it. Out of the common noises of the day, it weaves for you the song of the deep tides, the murmur of ocean caves and the croon of the breakers on the outer reef, and dull indeed is your inner ear if you cannot hear these things, and at the sound see the perfect curl of green waves and smell that cool fragrance which comes only from their breaking.

To the marshes in summer come the farmers from far inland, making holiday for themselves 


\section{ALONG THE SALT MARSHES I59}

while they work. They cut the short salt hay that seems so stiff and tough, that is so soft and velvety, in fact, and pile it on their wains and take it home to the cattle that like it better than any English hay that they can cut from the carefully tilled home fields. Indeed the cattle ought to like this hay. It is soft as the autumn rowen, and mixed with all the delicate, fragrant herbs of the marsh. The tang of the sea salt is in it, and no man knows what delicate essence borne far on the wandering tides to the flavoring of its fibre. No matter how long you may leave this hay in the mow you have but to stir it to get the soft rich flavor of the sea and breathe a little of that salty vigor which seems to go to the seasoning of the best of life. I have an idea the cattle love it for this too, and as they chew its cud inherited memory stirs within them, and they roam the marshes with the aurochs and tingle with the savage joy of freedom.

Out along the rocks to seaward at low tide go the mossers and with long rakes rip the carragheen from its hold and load their dories with its golden-brown masses. Then they bring it ashore and spread it out in the sun as the farmers do their hay, that it may dry and bleach. Just 
as the salt hay, touched for a brief happy hour at each tide with the cool strength of the sea, retains the flavor of it always, so the Irish moss that grows in the depths and is hardly awash at the lowest of the ebb, overflows with it and is so bursting with this fragrance of the unknown that no change that comes to it can drive it out. When the wind is off-shore and you may not scent the sea, when the sun bakes the hot sand and dries the blood so that it seems as if the only way to prolong life is to wade out neck deep in the surges and there stay until the wind comes from the east again, you have but to go to the leeward of these piles of bleaching carragheen to find it giving forth the same cooling fragrance which the tides have made a part of its structure. You may take this moss home with you and cook it, but the heat of your fire will no more destroy its essence than did the heat of the sun, and in your first mouthful of the produce, which may in appearance give no hint of its origin, you taste the cool sea depths and feel yourself nourished as if with some vital principle.

It is no wonder that under the glare of the midsummer sun people forsake the arid uplands 


\section{ALONG THE SALT MARSHES I6I}

and the vast, heat scorched plains of the interior and find renewed life and vitality on the borders of the Atlantic seaboard. The sea in the beginning was the mother of all life and we do not know what forms of future perfection she is now nourishing as filmy protoplasm in her depths. She gives us cool fogs to the reopening of our shrivelled pores and just by walking along shore we are touched by this vivific principle which gives such riotous life to all things. There is a saying among Eastern Massachusetts farmer folk that if you will bathe three times in the salt water during the summer you will not feel the cold of the coming winter. Thus is the old myth revived and the modern Achilles may find invulnerability beneath the Styx, nor need his heel be left above the tide for his undoing. And the sea has more than that to give us, more than physical well-being and invulnerability to the arrows of the winter winds. Out of the green depths come still the mysterious and the unknown and up over the blue rim sail day by day argosies laden with romance. Thus it has always been nor can the peopling of many lands and the finding and exploring of all continents and islands 
I62 OLD PLYMOUTH TRAILS

check this. However it may be with the cattle it is this which gives tang to our salt hay and touches the reviving coolness of the spray and the east wind with the rainbow magic of dreams. 


\section{CHAPTER XIII}

FISHING "DOWN OUTSIDE"

In the beginning of things were the cunners, known along Massachusetts Bay mainly as perch. Names are good only in certain localities. If you ask a Hingham boy how the cunners are biting he will be likely to throw rounded beach stones at you, thinking he is being made game of. Down at Newport, R. I., they catch cunners and if you talk salt-water perch to them it is at your peril. Elsewhere they are chogsett, or peradventure burgall, but everywhere they are nippers and baitstealers, and the trait which makes these names universal is the reason why in the beginning of things were the cunners. For the first bait of the first fisherman that ever threw hook into the North Atlantic was taken by a cunner. There are today forty million, more or less, North Atlantic fishermen who will corroborate this testimony with personal experience. It may be that the first hook was taken by some other fish, but the cunner got in ahead on the bait. 163 
The cunner is not very large. He rarely tips the scales at a pound, but he will eat his own weight in bait in a day and he is numerous and pretty nearly omnipresent.

Wherever the salt tides flow, whether it be up the sandy stretches of a clean bottomed cove, along the mud bottom of the creek, or amid the red-brown tangle of kelp on some ledge awash a mile off shore, there comes the cunner, suiting his color chameleon-like to that of the bottom.

On the mud he is brown, on the sand gray, but if you wish to see handsome creatures you must pull them from some bottom where the red kelp grows. Then their rich bronzy reds will make you forget their bait thievery and love them for their beauty.

If you will go back to Dombey and Son and read the description of Mr. Carker you will realize that Dickens must have been fishing off the ledges of some English headland when he planned that gentleman and his characteristics. In whatever mood or from whatever side Mr. Carker approaches you it is his teeth which dominate the situation. I am convinced that every time Dickens tried to make him otherwise he found another cunner tugging and drew him up. 


\section{FISHING "DOWN OUTSIDE” $\quad$ 65}

Judging by Carker it must have been good fishing for cunners. Like Carker this fish comes to you teeth first. His mouth is so full of them that they stick out like quills on the fretful porcupine. Nature, which gives each tools for the trade which he most loves, made him a bait-stealer extraordinary with these.

The beginner who fishes in the salt sea does it almost invariably with a pole, whether from cliff or dock or from a boat. Experience brings the desire for the hand line. The farmer's boy who comes down for the salt hay tucks his long birch pole into the bottom of the wagon and the trolley tripper comes to the beach with his split bamboo. Down in Maine years ago the pinkies used to sail equipped with numerous short poles whereby to trail for mackerel. In the day of your grandfather and mine it must have been a sight to see the crew of a pink-sterned chebacco boat dancing from pole to pole flipping the number ones aboard when a good school-struck in. Of course, all that is a.waste of energy and of wood. A hand line is the more intimate and serves the purpose better. A man is not really a salt water fisherman till he has learned the use of one. Then let him go forth. Through that line shall flow to 
his nerve ganglia deep sea knowledge galore. By it shall come to him in time all creatures of the vast deep.

Lovers of deep sea fishing grow best from sniall beginnings. They yearn from tide flats to the spar buoy in the harbor channel, thence through Hull Gut to the rocky bottoms about the Brewsters. After that the sirens sing to them from every wash of white waves over ledges far out to sea, caution drowns in the temptation of blue water, and they fish no more except it is "down outside." They who dwell on the very rim of this deep sea, at Marblehead or Nahant, at Cohasset or at Duxbury never know the full depth of its lure as do those who must win to it from the Dorchester flats or the winding reaches of the Fore River. To these latter only is the perfection of desire and the full joy of fulfilment. You can leave the shallow bays inland only when the tide serves, hence gropings for a tender on the beach of starlit mornings, the chuckle of halliard blocks in the rose of dawn and a long drift in the pink glow of morning fog while the boom swings idly and the turn of the flood drifts you 


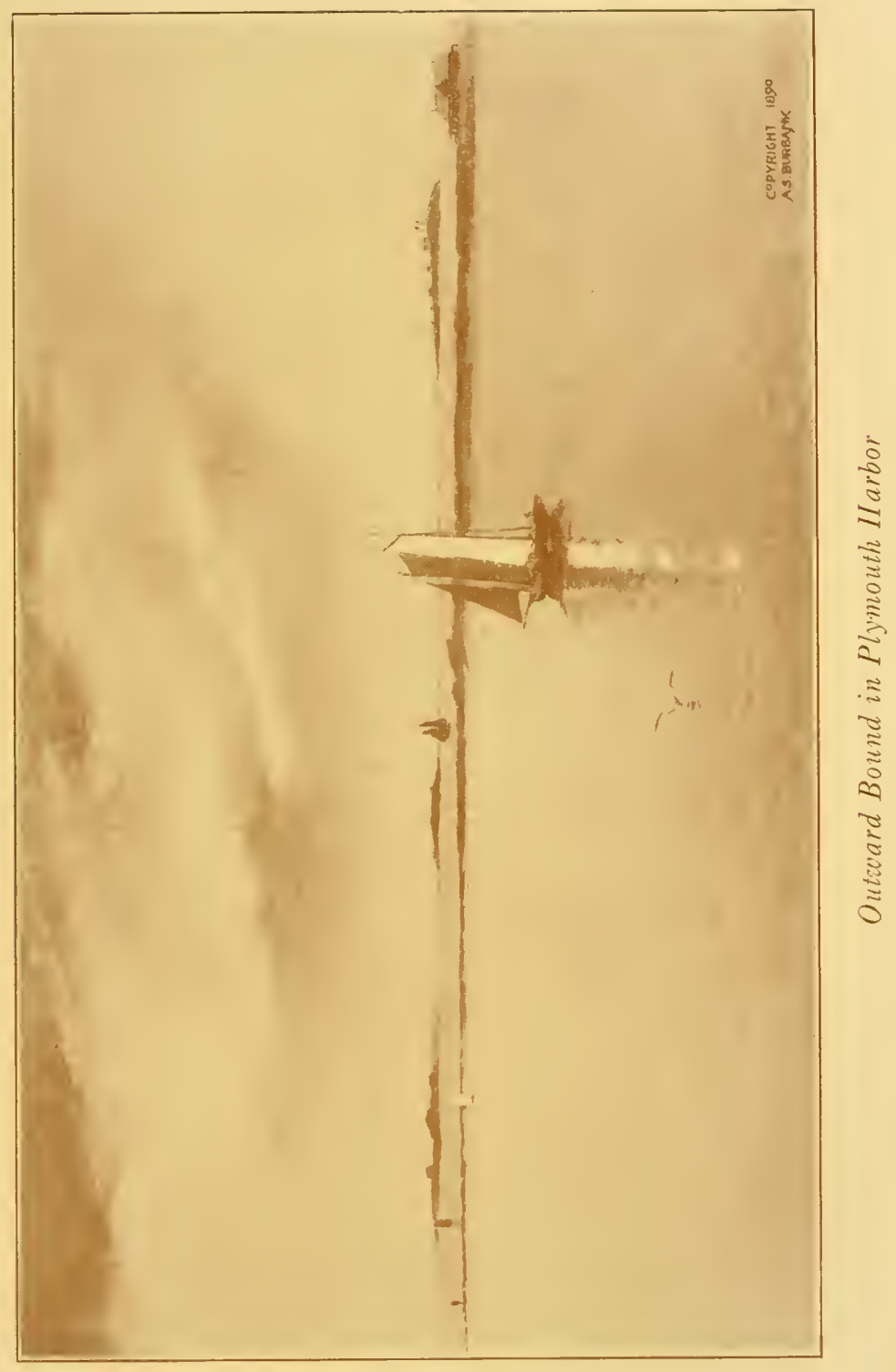



eastward. Little wayward winds, too lazy to make a ripple on the glassy surface of the water or stir the sail, play strange tricks with this morning fog. They carve chasms in it and open tunnels down which you see far for a moment, then they wind it like a wet sheet about you and you may not see the bobstay from your post at the tiller.

They bring you sounds and scents from afar. You know you are abreast Grape Island now for you scent the wild roses on the point. Another breeze brings faint odors of the charnel house from Bradley's. A stronger chases it away and you have a whiff of an early breakfast, brown toast, fried fish and coffee, at Rose Cliff. The chuckle of oars in rowlocks tells you that the old fisherman is astir at Fort Point and the man with the new motor boat over at Hough's Neck is giving it a little run before breakfast, with the muffler off, as usual. A gull goes over, flying low. You do not see but you hear the soft swish of the wings. By and by the sun shows through a rift in the fog and you begin to move before a faint air from the southwest. A half hour more and the shreds of fog are melting upward into the 
blue of a clear day, the wind fills your sail and you are sweeping eastward with wind and tide round the Sheep Island bar.

The Argo, bound eastward for the golden fleece, bearing Jason, Hercules, Theseus and the other Greek heroes, carried no higher hopes and no greater joy in the dangers and mysteries of the sea than does many a keen-bowed sloop or broadbeamed cat bound "outside" on a fishing trip. It is neither the goal nor the gain that counts. It is the spirit of the quest. The golden fleece looms eastward over all such prows. In the tide rip of Hull Gut, where current meets current at certain 'turns of the tide in such fashion that "the merry men" dance gleefully, is a dash of adventure, and if you come through with a cockpit half full of water and your clam bait afloat so much the merrier. Thus you are baptized into the sect of the deep sea rovers and the leap of the mysterious green dancers into your boat is the coming of Neptune himself. Henceforth his trident is at your mast head, a broom wherewith to sweep the seas as Van Tromp did. The conquerors are abroad.

You may bother about the skerries that skirt Boston Light if you will. There are cunners 
big and ravenous at the base of Shag Rocks or along Boston or Martin's ledges. I dare say there are flounders skimming the sand to the east of Hull, but you will hardly care for these if you have Neptune aboard. His spirit will bid you jibe your sail to that freshening west wind off Allerton and bowl down the coast parellel with the long stretch of Nantasket sands. Again at the spindle on Harding's Ledge you may catch cunners; perhaps a stray cod. A cod! There you speak a magic word to the fisherman from the tide flats far inland. There is the golden fleece for which the Argonauts of the land-locked harbor set their prows to the eastward in the starlight. A pull on the sheet and it is full-and-by to the southeast, with Minot's Light looming gray dead ahead in the gray wash of breakers. Black-headed gulls swing across your wake, and in their laughter rings a wild note of sea freedom. Thus the Vikings laughed as their boats won to seaward outside the black cliffs.

The cod is the solid citizen of the sea. In some localities they call him the ground keeper, and he seems to be that - a sort of land owner of the sea bottom. Just as ashore most substantial 


\section{0 \\ OLD PLYMOUTH TRAILS}

success comes from land-holding, and those who own the earth are almost invariably financial magnates also, so the cod is a banker. Some people, not financial magnates themselves in all probability, have given this substantial dweller of the under-water plateaus undignified names. They call him pilker, scrod, groper, etc. This is pure envy. When he bites it means business. There is none of the bait-stealing tomfoolery of the cunner, none of the dancing hilarity of the pollock. It is just a steady down tug that makes the line cut your fingers and likely takes your hand under water. If he is a good one you will need to sit back and snub the line over the gunwale in that first plunge which follows the stab of the hook. Then it is a steady, muscle-grinding pull to get him up. It is a stogy, heavy resistance which he offers. To lift him out of his depths is a good deal like explaining to a middle-class Englishman something that he does not wish to comprehend, but by and by, leaning perilously over the rail, you see his tawny bulk coming up through a well of chrysophrase lined with the scintillant gold of the imprisoned sun. A lift and a swing, and he is aboard. He may weigh anything from a few pounds up to a score. Cod 
have been caught weighing I 50 pounds, but not in Massachusetts Bay of late years.

A half-mile to the east of Minot's and southward to beyond Scituate harbor runs an irregular ridge along the sea bottom at a depth of six to ten fathoms, while to the east and west is deeper water. Something like a half-mile farther eastward again you will find another, both probably moraines of sand and gravel on the sea bottom like those one finds ashore. These ridges the fish seem to frequent rather than the valleys between, and if you will ease your sheets and, setting your boat's prow a little off the wind, drift slowly along these ridges, you will be able to cast your lines among the best of the summer society. The cod go into things only on the ground flood. It is a way substantial citizens have. You will need to let your sinker strike bottom and then lift it a little, but not too far. A greased lead dropped will show you a variety of bottom. Here are rocks, about which especially the cod congregate and where sometimes giant cunners dwell, there is a sandy stretch which is beloved of the big flounders, which when hooked make a gallant though unsteady fight before you get them up.

I am always sorry for the flounder. He looks 


\section{I72. OLD PLYMOUTH TRAILS}

as if he might have once been a fish of respectable, perhaps even beautiful shape and proportions, that had met with an accident. He is a shore frequenter, especially when young, and I cannot help thinking that in antediluvian days when mastodons were plentiful and went wading they stepped on the flounders. A flounder is shaped just as if he had been run over by an Atlantic avenue truck. His eyes moved over onto one side of his head, fleeing hand in hand to escape the wheel. His mouth was mashed fairly and seems to be perpetually ejaculating "Help, murder!" and one side of him is still white as snow with the fear of the affair. He ought to be in a cripples' home, but he is not. Instead he is as jolly as a sand man and amply able to take care of his wreck of a body, which is flat indeed but fat. Necessity is the mother of invention. When the flounder sees food that he wants he falls upon it and holds it down with ease while he devours it. A slender fish would have no such chance.

At this time of year come roving northward from unknown feeding grounds outside the Cape the haddock. There are people who call the haddock "scoodled skull-joe," probably in derision 
because he is such a dapper fish. He is so silvery and neat that the black stripe down his side seems to give him the effect of being clad in the very latest thing in summer trousers. The Banks fishermen who sail from Gloucester and are probably more intimately acquainted with the personal affairs of fishes than anyone else, say that the haddock, though now reformed, has not always been what he should be. The haddock, they say, was once such a young sport and conducted himself in such unseemly fashion that he was in danger of hell fire. In fact, the devil, searching the Grand Banks for whom he might devour, took the shameless youngster between his finger and thumb and held him aloft in glee, saying, "You for the gridiron." But the agile haddock, skilled in getting out of scrapes, squirmed loose and fled in the depths of the sea. In proof of this adventure if you examine a haddock's body just behind the gills you will see the marks where the Old Boy's fingers scorched him, the scars remaining to this day. I am not sure whether this fable teaches us to be good or to be agile.

With the cod, as often most intimately with him in the boneless codfish box, come the hake 


\section{I74 OLD PLYMOUTH TRAILS}

and the cusk, both rated as inferior fish, though it is hard to see why. The cusk in particular is esteemed by the fishermen for their own use above any other fish that is taken from the trawls on the banks. Go down into the forepeak of any Gloucesterman and ask the crew, while they "mug up," jf they like baked cusk. You will see their mouths water and their eyes shine in appreciation of the suggestion. Yet the cusk is hardly a beauty. In fact, the first man who suggested eating him must have been hungry or else adventurous beyond the common run of men. If you will take a bilious looking eel and compress him lengthwise till the becomes a stubby bunch, put on him a pair of yellow goggle eyes that stare madly as if at ghosts, and seem, withal to be sadly afflicted with strabismus, you will have the beginnings of a cusk. Then he must have a broad fin that begins at the back of his neck, promenades his spine to and including his tail and returns beneath him to the spot where some people wear neckties. That is a part of the paraphernalia of this denizen of the deep sea. Often when brought to the surface this peculiar fish will swell up with imprisoned air until he is enormously fat and covered with blisters. 
The cod and the flounders, cunners and pollock will make up the bulk of your catch as you drift along these under-sea moraines, though now and then a freak may come to your hook in the shape of a dogfish or a skate. These are to be looked for and welcomed. Once the horse mackerel struck into Massachusetts Bay. These weigh a thousand pounds apiece and take live fish of considerable size on the fly. In those days a deep-sea fisherman, hauling in a respectable cod, was likely to find adventure enough with the situation suddenly reversed and a horse mackerel hauling in the line with the fisherman on the end of it.

It is leviathans of the deep like these that Jason Theseus and their companion Greeks bear in mind as the Argo drifts and the catch steadily grows. By and by the low sun flares red through surly clouds of nightfall. The sea is getting up and it is a long sail up the coast to the lee of the outer light. Then with darkness gathering and a head wind and tide the real glory of the day comes. Out of the black west blows half a gale. The waves curl in ghostly phosphorescence and the merry men dance wildly in Hull Gut. It is a long and dogged fight to win through these 


\section{I76 OLD PLYMOUTH TRAILS}

against the swift tide to the comparative safety of the shelter of Peddocks, where you catch the back wash that helps you well along the lee of Prince's Head.

And so the Argonauts sail westward again in the pitch blackness of the gathering storm. They know the harbor floor as they know the floors of their homes and can as well feel their way. What if the falling tide leaves the flats bare and they may not win to the mooring, but must lie at anchor off the channel edge until morning shows gray through the rain? They have won the golden fleece of adventure from the blue sea to eastward and sailed home with it. 


\section{CHAPTER XIV}

\section{VOICES OF THE BROOKSIDE}

For two hundred years the water has rippled over the sill on which once firmly set the gate to the old milldam. Of the mill, save this, no sliver of wood remains, and even the tradition of the miller and his work is gone. We merely know that here stood one of the grist mills of the early pioneers, a mill to which the neighbors brought their corn in sacks, perchance upon their shoulders, and after the wheel had turned and the grist was ground, carried the meal off in the same way. Thus rapidly does the smoothing hand of time wipe out man and his works.

But still the water ripples over the old, brown oak sill, and he who listens may hear the brook telling a story all day long in purling undertones. I fancy its language a simple one, too, but its words of one syllable tumble so swiftly over one another that, in spite of their liquid purity of tone, I never quite catch them. It is the brook's rapidity of utterance that troubles me. I am 


\section{I78 OLD PLYMOUTH TRAILS}

quite sure, always, that if I really got the syllables and wrote them down I should, with study, be able to translate it all. It ought not to be half so difficult as these hieroglyphic and cuneiform inscriptions on stone and brick buried in Assyrian ruins for ten thousand years, more or less, and now blithely put into modern speech by the Egyptologists.

The brook writes for me, too. On every placid pool at the foot of some race of ripples it mixes Morse-code dots and dashes with stenographic curves, all written in white foam on the smooth black mirror of the surface. Nor does it end there, so eager it is to call its message to my notice. Through the quiver of sun and shade it sends heliograph flashes to me on the bank, making again the dots and dashes of the Morse-code alphabet, yet still with such lightning-like rapidity that my dull eye fails to read. Only the foam writing gives brief opportunity for one to study the characters and decide what they mean. Sometimes there it is not difficult to find words in the Morse-code and phrases in the stenographic curves though I have no more than a word or a brief phrase before the current rearranges the puzzle and I must begin all over again. I doubt 
not many brookside idlers have done as much as that. I fancy many a summer couple, say a brave telegraph clerk and a fair stenographer, have worked out as much as "I love you" and "God bless our home" long before this.

After all, the brook is shallow and it is probable that it prattles merely the gossip of today and yesterday and the days gone by. Yet even so it might give me the story of this mill that so long ago stood upon its bank, something of the talk of the miller and his customer and the events of their time, matter I can get from no printed book nor from the tongue of man now living. Could I but get this I should have a rare book indeed, for nothing is so vivid to the reader as the true story of the plain life, the words and deeds of folk who lived a hundred or more years ago. The plain tales of Boswell, Pepys, Samuel Sewall, will live when all the series of six best sellers that have ever been are drifting dust.

The brook tells me more of nature than it does of man, perhaps because it has known man for so short a time, though I should say shows rather than tells. A hundred forms of life live in it and on it, while through the air above float a thousand more, or the evidences of them. Down 
stream come the scents of the flowers in bloom above. Just a week or two ago the dominant odor among these was the sticky sweetness of the azalea. It is an odor that breathes of laziness. Only the hot, damp breath of the swamp carries it and lulls to languor and to sensuous dreams. Mid-August is near and though here and there a belated azalea bloom still glows white in the dusk of the swamp its odor seems to have no power to ride the wind. Instead a cleaner, finer perfume dances in rhythmic motion down the dell, swaying in sprightly time to the under rhythm of the brook's tone, a scent that seems to laugh as it greets you, yet in no wise losing its inherent, gentle dignity. The wild clematis is the fairest maiden of the woodland. She, I am convinced, knows all the brook says and loves to listen to it, twining her arms about the alder shrubs, bending low till her starry eyes are mirrored in the dimpled surface beneath her, and always sending this teasing, dainty perfume out upon the breeze that it may call to her new friends. Long ago the Greeks named the Clematis Virgin's Bower, but our wild variety is more than that. It is the virgin.

To smell the perfume of the clematis on the 


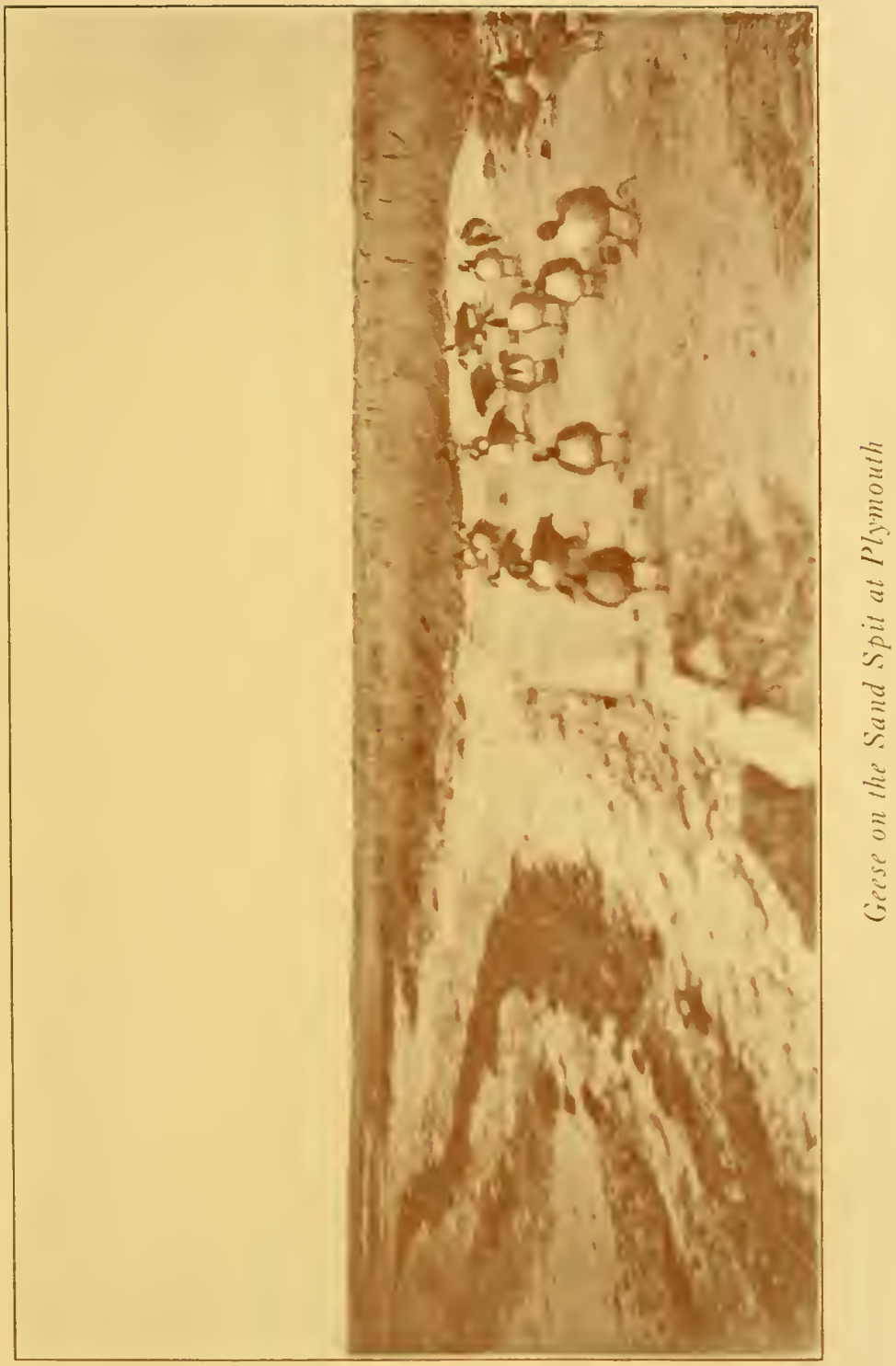





\section{VOICES OF THE BROOKSIDE I8I}

lazy wind and to watch the myriad people of the brook is joy enough for an August afternoon. Bird songs come to me from the trees overhead, far and near, some of them melodious, others songs only by courtesy. Down stream a redeyed vireo preaches persistently in an elm top. Across the pasture I hear the rich voice of an oriole stopping his caterpillar hunting long enough to trill a round phrase or two from the apple-tree bough. A flock of chickadees, old and young, comes through, nervously active in their hunting and with voices in which there is a tang of the coming autumn. Up in the pines a blue jay clamors with the same clarion ring in his tones. I do not know whether the different quality is in the air, or in the birds, but I am sure that after the first of August is past I could tell it by the notes of these two even if I had lost all track of the calendar. A black and white creeping warbler comes head first down a nearby tree, and then sits right side up a moment to squeak the half-dozen squeaks which are his best in the way of melody. Like a fine accompaniment the brook's voice blends with all these, mellows and supplements them till in the woodland symphony there is no jarring note. Nature has this won- 


\section{I82 OLD PLYMOUTH TRAILS}

derful faculty for soothing and harmonizing in all things. She will take colors that placed side by side in silks would cry to heaven for a separation, and combine them in a flower group, or sometimes indeed in a single flower, so skilfully that we accept the whole as beautiful without a question.

While I enjoy these things an eddy of wind brings from down the stream the fresh, moist smell of the water itself, and running through this I note just a suggestion of musk. All the other scents and sounds have been of a soothing quality, especially in combination with each other. In this suggestion of musk is something which bids one sit up and watch out. By and by I see the beast, a muskrat, steamboating his way up the rapids like a furry Maid-of-the-Mist, or perhaps I should say a submarine, that navigates the surface with but little bulk exposed. Presently he proves himself a submarine by diving in a shallow. I see his paws stirring up mud and presently again he comes to the surface with a fresh-water clam. Clams in August are good, though I confess I have never tried the freshwater variety. The muskrat knows, however, that these are good. He sits up on a rock, 


\section{VOICES OF THE BROOKSIDE I83}

washes the mud carefully from his catch, opens it as readily as if his incisors were a knife, smacks his lips over the last of its contents, peers into the empty shell as if he hoped to find a pearl, drops them and bustles on his way. I do not know his errand and I doubt if he does, but I know it was an important one by the way he goes on it.

The passing of the beast, however, upset the life of the shallow, amber pool. The mud of his digging had no more than cleared away before the under-water creatures of the place, jackals on the lion's spoor, came forward, eager to feast on the remnants of his meal. Bream, sunning themselves on the shallow margins of the other side, give a sinuous swish to their tails and dart up. A yellow perch poises, slips forward a yard, poises again and then thinking the place safe, comes forward for his share. In beauty and intelligence the yellow perch is easily the king of the brook waters and I can but admire his coloring, not only for its beauty but for its protective value. His dark back makes him almost invisible from directly above. Should you get a glimpse of his side you might well think it but the ripple of sunlight and shadow in the water, 


\section{I84 OLD PLYMOUTH TRAILS}

so well is this simulated by the broad bands of green and yellow which run from the dark back down the sides. It is only when he turns far on his side and gives you a glimpse of red fin and white belly that he is plainly visible, and only desperate need will make him thus turn.

After perch and bream have left, satisfied, a little group of thumbling hornpouts come and grub and dabble in the muddy hole whence the unio came, feeding upon I know not what; probably tiny infusorix of the fresh water. These little black cats are the busiest folk of the brook at this time of the year, and just whence they come or whither they go I cannot say. If you fish the waters with angle worms you will not pull out one of these little fellows till the summer is fairly on. Then, dog days having arrived, you will get a chance to catch nothing else, so long as one of them remains in the pool you choose. They are great angle-worm chasers and will get across a pool and grab a bait before any other denizen of the place can possibly get to it. Their agility is the more surprising when one remembers that the grown hornpout is but a sluggish chap and that they are not built on lines that presage swiftness. You may catch the big horn- 


\section{VOICES OF THE BROOKSIDE I85}

pouts at any season, but these little chaps are peculiar to the dog days. I have an idea they hibernate in the mud at bottom until warm weather calls them forth, and that by next spring, so voracious is their appetite and such their agility in satisfying it, they are as big as the others of their kind. So eager are these gourmands for bait that if but one is in a pool you may catch him, throw him back and catch him again times without number, provided the hook does not happen to injure his tough jaw.

Such a glimpse of the submarine life of the brook the muskrat has given me with the musky odor of his passing. After a little all is quiet down there and I have a chance to admire the life which flits above the surface. The hawking dragonflies weave gossamer fabrics of dreams in their unending flight to and fro and the lull of the forest symphony bids one yield to these as the waning afternoon builds up its shadows from all hollows and glens. In the open pastures the heat still quivers, but here the woodland deities are building night, block on block, for the cooling and soothing of the world. The heliographing ceases. The foam writing blurs in the shadows. Down long aisles of perfumed green the voice of 
the wood thrush rings mellow and serene. Here is a woodland chorister who sings of peace and calls to holy thoughts, voicing the evening prayer of the woodland world. As his angelus rings out I fancy all wild heads bowed in adoration. Certainly the wood thrush's call touches that chord in the human breast. To listen to it with open heart is to know all things are for good and that a peace from mystic spaces far above the woodland is descending upon it. Heard through this song the tone of the brook's voice changes and instead of swift-syllabled gossip I seem to hear it softly crooning a hymn. 


\section{CHAPTER XV}

GHOSTS OF THE NORTHEASTER

"The Fourth of July is past; the summer is gone," says a New England proverb. In this as in many a quaint saying of our weather-wise, hilltramping ancestors, there is more than a half truth hidden in what seems a humorous distortion. In mid-August we look about us and know this, for we see ourselves slipping more and more rapidly down the long slope that leads from flower-crowned hilltop to frozen lake. Some day a snowstorm will get under the runners and the balance of the descent will be but a single shish. Meanwhile we may note the passage by certain landmarks. In the seven weeks that come between the longest day and the fifteenth of August, thunderstorms may bring local relief to the parched earth, but otherwise it is our dry season, and by the first week in August the farmers are holding their hands to heaven in vain prayers for rain, vowing that never was so dry a time and that if the seasons thus continue to cirange Massachusetts will be a desert. 
Always during August Jupiter Pluvius is wont to change all this. He sends us not showers, but a rain that wets us for a day and a night and perhaps longer, and, however greedily the parched earth may suck it up, finally irrigates all the waste places and covers all the sore earth with a soothing, healing salve of mud. Such rains comre in to us riding on the broad back of the east wind, as rode the prince in Andersen's fairy tale, and as the big drops fall upon us we catch intoxicating scents borne to us from far Cathay. On the east wind's back the prince rode into paradise itself, which still lies hidden beneath hills to the eastward of the Himalayas. We should not blame him for kissing the fairy princess and being banished, for if he had not done so he had not brought back the tale and we should not know whence came the soothing odors that drip with the rain from the wings of the east wind. Fragrance of spice and of flowers, bloom of ripe fruit, of grape and fig and pomegranate and quaint odor of olive, scents that have ripened long in the purple dusk of paradise, the east wind caught in his garments and bore back to the cold forests of Northern Germany that night that the prince rode with him. Nor 


\section{GHOSTS OF THE NORTHEASTER I89}

has he since lost them altogether in crossing the storm-tossed Atlantic to our shores. Instead the rich vigor of the brine subtends them and bears them, tanged with salt, to our deeper delectation. In long carriage they have lost potency, one needs keen scent to find them, but all the subtle essence of dreams is in them still, and as the rain brings down early twilight you know that the prince saw true.

So likely is this storm to come to us in midAugust that the Old Farmer's Almanack, less oracularly and more bluntly by far than in its usual weather predictions, bids us look for it each year. Not only does its yearly recurrence make it a landmark of the passing of seasons, but the cold northwest breeze which almost invariably follows it, sucked in from Saskatchewan, breathing of snow flurries on the frost-touched tundra of the Arctic barrens, carries a threat of winter that all the world knows. The summer is over, it says to outdoor creatures, and it is time to put in fall stores. It is time to hurry all plans that need warm weather for their completion. Particularly do the late summer and early autumn blooming plants heed this. Monday saw my favorite meadow dallying still 


\section{Igo OLD PLYMOUTH TRAILS}

with the languor of midsummer. Even the tender pink orchid blooms of arethusa lingered among the grasses, in shadowy, cool-rooted spots, though the arethusa begins to bloom there in late May. Hardly have hardhack and meadowsweet, which are mid-summer plants, reached the fulness of mature bloom, so softly does the spring linger in this sheltered spot, so gently does the summer press her fervor on spring-watered sphagnum.

Crowding up among these have come green sprigs from perennial roots which are to bear on their tops yellow heads of goldenrod and loose panicles of purple asters. Yet on the day before the rain hardly had the green of the goldenrod tips become sun-glinted with yellow, scarcely an aster had lifted long lashes far enough so that you could see the iris beneath. After the rain the heads which had drooped so low in reverence before it rose in the clear sun and the whole meadow was cloth of gold where before it had been olive green with ripe grass tips, while all among the gold the blue asters came out like stars on a frosty evening, pricking through the pale glow of sunset. The meadow has lacked vivid color masses since June. Now it is a veri- 
table mixing pot for the autumn colors to come, yellow with goldenrod, blue with asters, purple with Joe-Pye weed, rosy because of the hardhack, and rimmed with delicate gray-white of thoroughwort. These colors it will hold until the maples take fire and the green of birches pales to softest yellow at the expectation of October. So the flash of coolness in the air after rain set all the woodfolk busy. The squirrels seemed to scold more shrilly and dance along the boughs inspecting the swelling chestnut burrs with a livelier kick than before. About this time, too, the bluejays begin to be prophetic of autumn. Hardly through July and early August has a loud note been heard from these birds. Often the recesses of the pines have been full of a gentle tinkling whicker as of muted tin pans that practised in the hope of some day becoming real phonographs, voices of young and old bluejays holding family councils interspersed with quiet joviality, but there has been none of the strident clamor which is the autumn voice of the bird. Today, however, in the cool, refreshing breeze out of the northwest it rang through the wood with familiar vigor, a herald, blowing trumpets in advance of autumn. It is really all settled; 


\section{I92 OLD PLYMOUTH TRAILS}

the bluejay has announced it and summer is over.

As the rain brings down early twilight it brings not only dreams of faint odors of far Cathay, it brings also clinging in the gray garments of the east wind films of its mystery and romance. As the prince in his brief outlook through the window of paradise saw on the panes moving pictures of life which Time had set there, so through the dusk of the fields and into the tangle of the forest it is easy to see this wind from far Cathay moving pictures of Oriental magic and mystery. Gray djinns stalk across the open spaces in the gathering dusk and what magician from Samarcand or what prince or princess of India may float to earth on these billowing praying-carpets of rain gusts it is impossible to tell. In the open fields and on the forest edges the effect of ghostly mystery is enhanced by the strange personality which all things take on. The most familiar path becomes new to us and each shrub and stump stands forth, pressing upon our attention, a newly arrived being out of the realms of space.

Monday afternoon when there was just the promise of rain in the air the pine woods were so friendly a place that all the birds flocked in and 


\section{GHOSTS OF THE NORTHEASTER I93}

seemed to be full of soft and gentle jubilation because of this promise. The spaces that have been so quiet of late were full of feathers as they had been in June. Here were robins innumerable, flitting jerkily about and crying "tut, tut" in a subdued and genial way that was positively ladylike. Partridge woodpeckers flocked in, drolly jollying each other and making much talk, sotto voce. Not one of them cried aloud and though in their humorous antics more than one cried, "flicker, flicker, flicker," there was in it none of the usual horse-laugh tone of the highhole when he is on a rampage. It was reduced to a gentle whinny that seemed to vie with the boudoir-built notes of the robins. Bluejays were there too, but there was no clamor, just a gentle murmur of subdued tones in the soft, resinscented twilight.

In the twilight of twenty-four hours after, all my wood-rimmed world of pasture and meadow was filled with the eerie presence of the rain. It was not like a gentle shower of summer when the patter of falling drops is like a tinkle of fairy music and showers spell laughter. The coming of a local shower at nightfall is as gentle and seems as homelike as the gathering of the 


\section{I94 OLD PLYMOUTH TRAILS}

birds in the grove. In this east storm brought from far spaces on the wings of the east wind there was something of wild unrest. The cool, salt flavor of the air spoke of wild stretches of the North Atlantic where sea-fogs have touched the eerie loneliness of Greenland bergs and passed it on to the wind. In this ghostly dusk of driving mist the smear of the rain across the face is like a touch of phantom hands coming out of unfathomed spaces, gentle but uncanny. All the soft perfumes of wood and field seem beaten to the ground by this rain which brings with its salt tang faint breathings of some distant spiciness.

The gray light of the lower spaces goes up into the clouds and in the dusk below shadowless shrubs take on strange shapes. The pasture edge is familiar no longer. Gray groups grow where surely was but clear space and all across the long meadow and up the slope mist horizons jostle one another one moment and are blotted out the next. The road entrance to the wood is a black cavern out of which lean grotesque goblins that wave a disquieting welcome. Here to the right and left as I enter stand black figures where in daylight I am sure nothing stood, nor 
does it help to lay the hand on them and know they are stumps. It is damp and draughty as it was in the cavern where the prince first found the east wind, and I look about half expecting to see the strong old woman who tended the fire and put the winds in bags when they did not behave. There she stands in the dusk nearby and only by putting my hand on the prickly needles and the rough trunk do I recognize a familiar pitch pine. The trees near this entrance to the enchanted wood sigh as the east wind touches them, seeming to draw deep breaths as living creatures might and thus add verisimilitude to the terror that stands on either hand to reach for me. Thus ancient hermits depicted the soul on the walls of their caverns, a shrinking shape that fled among goblins that clutched at it from all sides. The primal instinct of fear of things half seen still lurks in each man's bones. On a pitch dark night I had made the entrance to the wood without thought of ghosts. It is the half known that frightens us.

Once within the wood in the deepening dusk I seemed to leave the bogies behind. Not far through the pines the path brought me to a half cleared hollow where three-year sprouts mingle 


\section{I96 OLD PLYMOUTH TRAILS}

their lush aspirations with scattered growth seeded half a century ago. A lone deer seems to make this spot a sanctuary. Often in daylight we meet here almost face to face and look at one another curiously, neither much afraid. In the deepening darkness, just freed from the primal terrors of the wood edge, I seemed to know why the deer finds the place a refuge. Here in the little sheltered hollow no goblins gibbered, no banshee wailed in the wet wood. Instead the sprout clumps seemed to rustle cheery assurance and the taller trees to bend in cozy friendliness over them. The soft fingers of the rain had a soothing touch and wind and darkness were kindly. I do not know why some spots in the woods seem thus to shelter and protect whether by night or day while others repel or fill with distrust, but I know it is so. On a woodcock haunted slope or in a thicket beloved of ruffed grouse I almost always feel as if my camp had been pitched in some previous existence and I had just got home again, though the place, perhaps, ought to be new to me. I fancy the deer feels that way and I hope he was snuggled down in the shelter of some of those big-leaved sprouts, warm and dry, as I passed by. 
Down the glade and along the swamp edge I passed with the night falling fast. Twilight lingers long in our latitude and the gray sky still lighted the path dimly, though the woods were black on either side. The tranquillity of the home-like hollow was with me yet, but I was in for another panic shudder. A fitful gleam of pale light showed just ahead of me through the black thicket and I rounded a familiar curve in the path to stand face to face with a most portentous presence. A veritable ghost stood just within the wood, seven feet tall, stretching out a rattling bone of an arm and glowing from shapeless head to formless foot with pale gleaming garments of bluish white.

More years ago than I like to count up there used to come to my town an old man with a magic lantern. He would hire the audience room in the ancient town hall for an evening, hang up a sheet, charge ten cents admission and show to a crowd of wondering and delighted urchins pictures wonderful, humorous and startling. He always wound up with one for which he apologized, then showed it with much gusto, saying that he did not believe in such things himself, but that some people liked to see them. 
This was "death on the pale horse," and boys used to band together and see one another home through the darkness after looking at it. The creature that pointed his fleshless arm at me from the thicket was not that of the old time magic lantern exhibit, but it reminded me of that immediately, probably because it struck the same formless shudder through my bones. Yet it was only for a moment. I had seen such phosphorescent ghosts before and I had but to step boldly forward and give the stub a kick to send the spectre flying in fragments that dropped like huge glowworms in chunks to the sodden ground. Often in a northeast rain after long drought a rotten birch stump will thus glow with phosphorescent fire producing a most formidable and tradition-satisfying ghost.

There is nothing to be feared in a phosphorescent birch stub, even with the drip of rain from the leaves making stealthy, ghostly footfalls all through the wood and the voice of the east wind in the trees overhead beginning to take up a querulous, wordless complaint that moved back and forth with the footfalls. Foxfire is a common enough phenomenon. It is easy to explain it all as I do now. The strange part of such 
things is always that, at the time, no matter what a man's training and experience, he feels creeping back and forth in his bones the old, pale terror of primitive man in the presence of such things. Science has veneered us with knowledge of phosphorus and the chemic action of fungi and the effects of darkness and of light, but a half hour's tramp into the wet woods while a northeaster blows through the darkness takes all the gloss off that. We may go boldly on our way with undiminished front, but something always stirs uneasily within us and looks out at the back of the neck to see if that scattered glow has not reassembled and followed us.

Soon the path led me up out of the swamp, the sooner perhaps for the glowing eyes of foxfire now far behind, and I caught the beckoning gleam of electric light through the quiver of the rain. From the brow of cemetery hill the country below rose from velvety blackness of complete night to a gray sky that was somehow comforting and friendly. Through it, far down the road toward Blue Hill, the street lamps glowed yellow through the gloom, showing the route to the invisible hill. The wind crooned in the pines, and the swish of shected rain seemed a lullaby. 


\section{0}

Here again, like the deer-frequented hollow, was a homelike and friendly spot. Even when I faced the street I found nothing disquieting in the sudden gleams of reflected light on the wet headstones. These should have been far more terrifying than any foxfire. Recent traditions of the race make the cemetery a place of ghosts, and here within its bounds were gnome lights that sprang into being, flared brightly for a second, then flashed out of sight as I walked. The long row of lights seemed to give almost every stone its turn, and the dancing gnome lanterns flared and vanished behind and before. As I neared the street puddles in the path caught up the flashes fitfully till all the quiet acre of the dead seemed full of goblins bobbing up from below with lanterns, taking a hasty look about, then pulling the lid down upon themselves with an unheard slam. It should have been disquieting, but it was not. We easily discount the petty superstitions that tradition and the frills of literature have made for us. That that grows out of the foxfire in the swamp has its roots too far back in the inheritance of the race to be discounted. The cemetery ghosts made only a friendly illumination for the last stages of a pleasant trip. 


\section{CHAPTER XVI}

JOTHAM STORIES

Almost daily in our hottest season the east wind brings coolness and refreshment to the dwellers at the sea beach. Nor does it stop at the seacoast. Often hills a dozen miles inland feel its cool caress.

The inland, simmering beneath the sun, with the thermometer in the eighties or worse, sends heavenward great columns of heated air. To take the place of this the lower strata draws in from the sea, filled with the coolness and sparkle of the brine and informed with that mysterious tonic which seems born of wind-tossed salt water. At such times the east wind brings the breath of life to our nostrils and sets the jaded motor centres of our nerves atingle with new power.

Often we dwellers far inland get more than a cool breath of the sea. Then for a day or two a northeaster comes pelting over the seaward range of hills, murking the sky with dun clouds, whining about the eaves and roaring down the chim- 
ney, bringing deluges of rain to the heat-browned pastures and draping them in obscurity of gray mists, blotting out the roar of cities and the flurry of modern life, making us belileve for a little that we are children of the farm once more. On sunny days we do not quite get this. Even in the east wind we smell the soot as well as the sea, but the genuine northeaster shuts all that out.

On such days the work of the farm ceases. What hay is out is cocked and capped, snugged down to wait for fair weather. The weeds in the graden drink and drink again and forget the hoe which idles in the tool-house corner, and Jotham putters about the barn, making pretence of indoor work but really, luxuriating in idleness. The place is redolent of the rich, sweet odor of the new hay and mingled with this comes that salt tang of the east wind bearing scent also of all the hills and pastures over which it has blown. You may if you will tell what gust touched the elders in white bloom down by the brook, which one lingered in the swamp a moment to caress the azaleas, and which stopped only long enough to snatch a kiss from the sweet fern on the pasture hill-top. 
It is pleasant then to sit sheltered from the rain just within the wide barn doors, to hear the twittering of the swallows as they comfort their young on the beams, and to listen to the wind and to Jotham. The old-time New England farm hand - he who wore the smock frock as did his master while they both worked about the barn and then, the chores done, stood for half an hour in the dusk, either side of the barn door like caryatids, drinking in the pleasures of rest in the twilight - has passed, but Jotham remains. He has told the tales of his grandfather's exploits as a hunter so many times that he not only believes them himself but is equally sure that everyone else believes them.

Yet Jotham is in the main taciturn. It is only when the northeaster soughs in the eaves and brings him leisure that he drops into narrative. His tales are grotesque fancies, simple yarns withal, such as fluttered from the homely life of pasture and woodland in early days of enforced idleness to light on the threshing floor of some great old barn, or to warm themselves at the big kitchen fireplace on winter nights when the wind guffawed down the throat of the big chimney and 


\section{4}

\section{OLD PLYMOUTH TRAILS}

sprinkled the hearth with an attic salt of snow for the seasoning of them for the country palate. I do not doubt Jotham's grandfather told them of his grandfather and that they belong to neither but are local folk lore, pasture sagas, changelings born of the queer union of east wind and blueberry blooms, brought up by hand - farm hand.

"My grandfather," says Jotham, "was a great hunter. On stormy days like this he would take down his old long, singlebarrelled gun and go out and bring home all kinds of game, mostly ducks and geese. In his day the ducks and geese bred around here and you could get 'em any time, but the best shooting was in the early fall on a northeaster. The heavy waves down on the coast drive the birds out of their feeding grounds and they come up to the fresh-water ponds inland to drink and get a change of feed. It is the same way with the shore birds, yellow-legs and plover and the like, though in my grandfather's day they didn't care much about such small game. Bigger birds were plenty enough. Grandfather used to hate yellow-legs, though, for they are telltales.

"Once he went over to Muddy Pond loaded for duck. It is a great place for ducks. In 


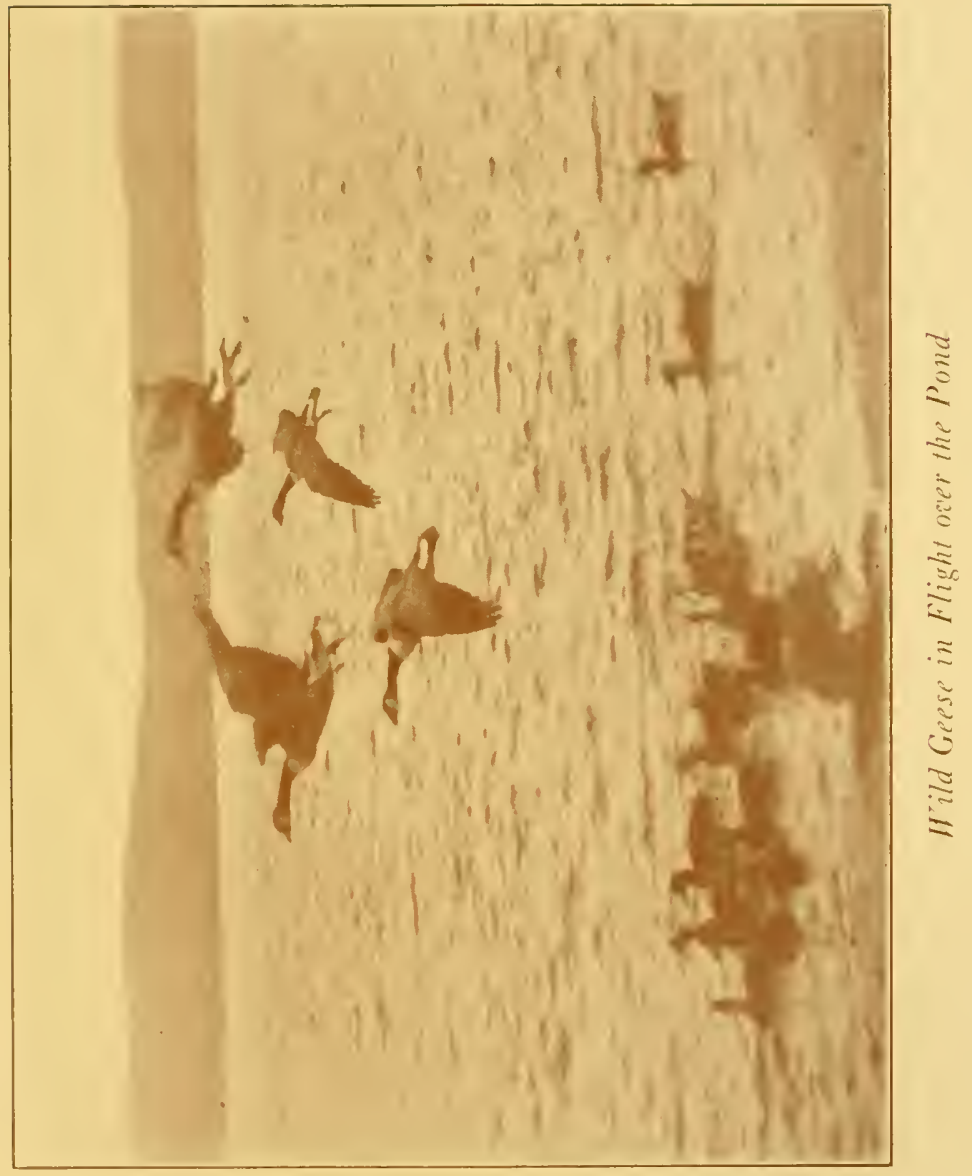




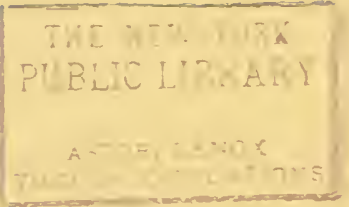


those days they used to come in there and sometimes pack it solid full. You could hardly see the pond for the ducks in it. Grandfather always knew just the right day to go, and this time when the looked down on the pond from the hill he saw hardly any water at all, nothing much but ducks. It was the chance of his life. He slipped down the hill among the scrubs to the cedars and then began to creep carefully up. You know what the pond is like, perfectly round and only a couple of acres or so, with a rim of marsh and then another big rim of swamp cedars, then the hills all about, neither inlet nor outlet; a queer pond anyway and queer things happen on it, same as they did that day. Grandfather had got half way through the swamp cedars when he came to a little opening which he had to cross. Just then there came up on the east wind a big flock of telltales, 762 of them, whirling over the hills without a sound till they saw him. Then they began to yelp."

"Look here, Jotham," I am always careful to say at this point, "How could he tell that there were just 762 of them? He couldn't count so many as they flew."

"Didn't have to count 'em as they flew," 
answers Jotham. "He counted 'em after he had shot 'em.

"Well, they began to yelp 'I_ook out for him! Look out for him!' and the ducks knew what that meant. All that great blanket of ducks uncovered the pond with one motion. Grandfather said it was just like a curtain rising straight up, for they were all black ducks. There is no other duck can go straight up in the air. Other ducks slide off on a slant against the wind."

How Jotham manages to put the lonely quaver of the yellow-leg's call into that phrase "Look out for him! Look out for him!" with its fournote repetition is more than I know, but he always does, and you can see the big flock swing through the mist as he says it.

"Grandfather was pretty mad to lose that chance at good game and he made up his mind that he'd take it out of the telltales, so he began to whistle 'em back. He was a master hand at any wild call and pretty soon he lit the flock. There they were, a rim of yellow-legs all around the pond, a perfect circle except in one place, where some dogwood bushes made down to the 


\section{JOTHAM STORIES}

water's edge. Then granddad had a great idea. He saw his chance to kill every one of those infernal telltales where they sat. He studied on the size of that circle for a minute. Then he put the long barrel of that old gun between two swamp cedar stumps and bent on it careftilly. He kept doing this,-looking at the circle, then bending the gun barrel till he had the gun bent just on the curve of the circle of yellow-legs sitting round the pond. Then he smiled for he knew he had 'em. He crept carefully into the dogwood bushes till he was in just the right place, took a good aim round that circle, and then he onlatched orl 'em.

"Well, he'd figured that circle just right. The shot swung round it and killed every one of them seven hundred and sixty-two yellow-legs right where they stood. But tarnation! He'd forgotten all about himself, he was so interested in the science of it. The back of his neck was right in that circle and the shot came round true as could be and hit him right there. The force of it was pretty well spent going so far and killing so many yellow-legs, but it dented some bits of dogwood leaves right into his system and he had 
dogwood poisoning pretty bad. He used to have it every year afiter that, about the time the first northeaster set in."

Anybody who knows Muddy Pond will know that Jotham's story ought to be true, for the pond is there to prove it, just as he describes it.

"Of course," says Jotham at this point, "that was skill. Not one hunter in a hundred would have thought to bend his gun so as to throw the shot in a circle or would have been able to estimate the amount of the curve so exactly right. Another thing happened to my grandfather over at that pond that was part skill and part luck. He was on his way home from partridge shooting one day just before Thanksgiving. He found he was out of shot just before he got to the pond. His flask had leaked and let every bit of the shot out, and when he came to load up after shooting his last partridge he stopped with the powder, for there was no shot to put in. Just then he came in sight of the pond and there were seven geese swimming round in it; and that the day before Thanksgiving!

"It was a tough time to be without any shot, but grandfather was equal to the emergency. 


\section{JOTHAM STORIES}

He simply left his ramrod right in the gun, put on a cap, and began to worm his way through the cedars to the shore, where he could get a good, close shot at the geese. Just as he did this another hunter who was no kind of a shot, came to the other side of the pond and saw the birds. He was one of the kind that have the buck fever at the sight of game, and he put up his gun and shot slam at the flock, too far away to do any execution, then he let out a yell and began to run down to the shore as fast as he could go.

"Of course he scared the geese and they lit out, swinging right by grandfather. Grandfather was a nervy hunter. He held his fire till he got the heads of those seven geese right in line, and then he shot and strung 'em all right through the eyes with the ramrod. Granddad couldn't quite see where he had hit 'em, but when the smoke cleared away he saw the seven geese still flying and his ramrod going off 'with 'em, and he was some considerable astonished and a good deal put about at losing his ramrod.

"Now here's the queer part of it: Those seven geese were blinded, of course, with a ramrod strung right through their eyes, but the life 
in a wild goose is powerful strong and they kept flying on just the same, until they went out of sight, right in the direction of granddad's home. But he got home and had hung up his gun without seeing anything more of them and he thought his ramrod was sure gone for good. Then grandmother came to him, kind of scared, saying she heard spirit rappings on the pantry wall. Granddad heard the noise, a sort of tapping, but he couldn't see anything until he looked out the pantry window.

"Yes, there they were seven of 'em, hung on the ramrod and the ramrod hung on a blind-hook, just outside Granddad's pantry window, their wings still flapping a little and making that rapping sound, just as if they were knocking to be let in at the pantry of the man that had shot 'em. All the relations used to come to grandfather's for Thanksgiving, and thirty-five of 'em sat down to dinner that year and every one of 'em had all the roast goose they could eat."

Frightened or injured game birds do perform strange feats as many an honest huntsman will tell you. I myself have a neighbor, no relative of Jotham's, who shot at a partridge in the woods a quarter of a mile from his house and saw the 


\section{JOTHAM STORIES}

bird fly away. When he got home a half-hour later he found his pantry window broken and a partridge lying dead on the pantry floor, either the one he had shot at or another just as good and as the proverb has it, one story is good until another one is told. Jotham usually caps his list with the following:

"I guess the greatest wild goose hunting grandfather ever did was the time the big flock got caught in the ice storm. It came in November, a foot of soft snow and then one of those rainstorms that freeze as soon as the rain touches anything. Every twig on the trees that storm was as big as your wrist with ice and there was an inch or two of clear ice on everything and more coming all the time, when grandfather heard a big flock of wild geese honking. They didn't seem to be going over, but their voices hung in the air right over the big steep hill from the barn up into the back pasture. After they'd been honking up there for some time grandfather went up to see what it was all about, but he didn't take his gun. As he climbed the hill through the wet snow he heard 'em plainer and plainer, and when' he got to the top he saw a most 'strodinary sight. There was a good-sized flock, ninety- 
seven geese, to be exact, that had got so iced up that they had to settle on the top of the hill.

"The ice had formed on their feathers as they flew and they were so weighted down they couldn't fly and they were getting more and more iced up every minute. Granddad didn't care to go back for his gun for fear some of the other nimrods in the neighborhood would come on the scene and bag the game first, but there wasn't any need of a gun. All he had to do was to drive 'em home. They were terribly iced up, but their legs were still free and he chased 'em about for some time before he got 'em started down hill. But once over the edge of the hill the weight of ice on 'em turned 'em right over and over, and so they rolled on down. It was a wet snow and as they rolled they took up more and more of it till by the time they came slap up against the side of the barn every single goose was sealed up in the middle of a hard, round snowball. They all stopped there and all that grandfather had to do was to pile them up, and there they were, in cold storage for the winter. Every time the family wanted roast goose they went out and split open a snowball. The folks in granddad's time used often to freeze their fresh meat and 


\section{JOTHAM STORIES}

keep it out in the snow all winter, but he was the only one that I ever heard of that stored wild geese in that way."

There are worse tales and more of them, but I fear that cold type chills out the subtle aroma of probability with which Jotham always manages to invest them. One needs to hear them told with the fragrance of a barn full of newmade hay in the nostrils, the swish of the northeaster to accompany the voice in his ears, and with his eye on the distant hillside pastures all hung with mysterious draperies of mist to make a proper background of quaint shadows of romance. Then he can really appreciate the folk lore that goes with us by the familiar title of "Jotham stories." 


\section{CHAPTER XVII \\ GOOD-BYE TO SUMMER}

I think the daintiest scent that can be found in the woodland in these last days of September is that of the coral-root flower, which looks like a wan, tan ghost of a blossom, but nevertheless is sweet and succulent. The plant is by no means common in my world. Many a year goes by without my seeing it at all. In autumn it grows from among dry pine leaves, a slender spike that has neither root leaves nor stem leaves, but looks like the dried flower scape of some spring blooming plant. So protective is its coloration that I stand among its blooms and look long before I see them at all. It is only by getting very close that one can see that the tiny forests scattered along the pale brown scape are themselves beautifully colored with purple and white on the same soft $\tan$ foundation as the scape. They have, too, the quaintly mysterious formation of all orchid blooms and that alluring, elusive odor which must be sought intimately to be known. You 
must get this dainty perfume where it grows. If you pluck the blooms and take them home they will hold their beauty and color for days, but the scent will have strangely slipped from them and trembled along the still, soft air back to the woodland haunts whence it came. You might find it there, wandering disconsolate in the lonely brown spaces seeking for its own heart of bloom, but from under your roof it has departed.

The flower is a strange one, anyway, in all its growth. Fibrous roots it has none, just a bunch of coral-like tubercles which draw nourishment by their own subtle processes from the roots of trees that shade them. Leaves it has none, just a scarious brown bract that encloses a part of the stem. Living upon canned food, so to speak, it has lost its ability to win sustenance from earth and air. It seems to live, not upon the sap of these trees, but upon the dead roots and decayed wood, a specially prepared humus without which it may not thrive, even in its own limited, elusive way. Among our wild flowers doomed to ultimate extinction I fancy this will be one of the first to disappear. In the days of great stretches of moist, deep woodland it may well have flourished. 


\section{I6 OLD PLYMOUTH TRAILS}

In my town it is rare and any year I may find it for the last time. On many counts I would not miss it, and yet that faint, refined odor which somehow always reminds me of ghosts of $\mathrm{mi}$ gnonette, of tender, almost forgotten memories once more stirred, gives a gentle melancholy to the woodland that all the glories of October will not be able to assuage.

It is by such subtle hints as this that autumn announces her presence among us. The prevailing tone of the upland wood is yet that of summer. Hardly will you see a splash of color in all the miles of green. It is in shady woods where no frost has yet penetrated, spots like that in which the coral-root is sheltered and befriended that nevertheless you read the open tale of what is to come. In low-lying open meadows the frost has spoken. In these on one night the chill of frozen space weighed down and turned the dew to ice and wrecked some tender herbage, leaving it brown as if touched by fire instead of frost. But it is only here and there in places peculiarly subject to this warning that this has happened. In shielding forest depths the coverlets of mul- 
tiple green leaves have kept the tender things of the wood wrapped warm through the nights and the frost has said no word. Yet there too the message has penetrated, by what means I cannot say. The ferns have heard it and have turned pale. The tender, slender fronds of the hayscented Dicksonia are very wan and the odor from them now as you tramp through is not so much that of new-mown hay, as it was in June, but rather that of the stack or the mow, always with their own inimitable woodsy flavor added. The brake whose woody stems have held its ternate, palm-like fronds bravely aloft all summer is now a sallow yellow, and the lovely Osmundas and stately Struthiopteris are bowing their heads in brown acquiescence with the inevitable. I doubt if it is a message from the air. It is rather a command from the nerve centres at the base of the stalk, a message from the brain of the heart-roots that gives the fronds warning that their day is over. If it were in the air the polypodys, the Christmas ferns and the spinulose wood ferns would have lost their color also. It is different with these. There is a hardier quality in their nature and they seem to revel in the 
killing frosts of late autumn and the ice and snow of winter; I find them as green and as hearty in December as I do now.

Next to the tender ferns it is the woody undergrowth that recognizes the season first. Long ago some limb of a red maple growing in the shade has been seen to flare up with a sudden flame while else all the wood was green. But this in itself is no sign. This happens here and there in low ground even in very early summer. Now, hawever, it is not only here and there but every'where that you will find this occasional limb adding scarlet beauty to the sombre shade of the deep wood, and as your glance passes from the cool pale ferns to this it slips on and finds color growing on many things in the woodland shadow. Here is the cornel, whose lovely blooms filled the forest with butterfly beauty, it seems no longer ago than yesterday. Today I find the cornel foliage green still as to midrib and veining, but with the woof of the leaf gone such a fine apple red that it is surely good enough to eat. If color counts the deer should find rich browse in the shrubbery these days. The hazels that were so green are suddenly a ripe brown that is all warm with red tones, and where the summac grows 
there is forest fire without smoke burning in the scarlet flame-tongues of the pointed leaflets of this modern burning bush. And all this is beneath the shelter of the still green forest into which we must go to find it. From without the full green of summer ripeness prevails, and we must seek other signs of the autumn season.

But must we, after all? Yesterday or the day before it was true and we were saying that the summer held on well. Today, so suddenly does the change seem to become visible, I saw them blaze up out of a cool swamp at the foot of the hill on which I stood. The smoke of autumn's peace pipe was blue on all the distant hills, and he must have dropped his match in my swamp, where it smouldered and flared and caught the maple even as I looked in the full expectancy of seeing nothing but green. The red fire of greeting seemed to run from tree to tree, and all the lowlands for a mile were ablaze, as if some subdominant political party had won an unexpected victory and could not wait for night to light its fires of celebration. All the little swamp maples were red with this fire, and though I suppose they have been days in turning the effect was that of their flashing up as I looked. Then I saw that 
the birches among them were all set with candles, whose pale yellow flames lighted them with a most chaste fire, just as in the old days of torchlight enthusiasm over political campaigns we used to put rows of them in the windows on the night that the parade was to pass. Seeing all that I felt as if autumn were again triumphantly elected, and we all ought to take off our hats and "give three cheers for the illumination on the right."

Surely autumn is the finest season of the year. I always know that as soon as it gets here. Yesterday I revelled in the summer that had stayed with us so long and still seemed to show few signs of going. Today the fall coloring is burning, like a wood fire on a still day, slowly up from the swamps into the upland woods. Now that I have begun to notice it I see that the coloring is touching the underleaves of the hillside birches, those nearest the stem, and that perhaps one in five has the same cool, pale yellow fire alight. Thus rapidly does the conflagration spread from swamp to hillside, from the shade of the grove to its topmost boughs and before we 
know it the year will have once more set the world on fire.

As for those other signs, there is a whole calendar of bird voices and bird movements that might well give us the dates, day by day. To me the first warning of the passing of summer comes in the tin-trumpet notes of the blue jays. While the nesting season is on the blue jay is as dumb as an oyster. The woods may be full of him and his tribe, but never an old bird says a word. After the young can fly you may hear them if you slip quietly along in the pine woods. You have to be pretty near though, to do it. They sit in a family group in the treetops and complain, under the breath, hungrily. It is not until the young are well grown, the moulting season is over and the summer pretty nearly the same that any blue jay gets his voice. Then, almost as suddenly as the coming of autumn coloring in the trees the racket begins. You may not have seen a blue jay in the woods for months. Suddenly they appear in flocks, swooping down on the orchard in brand new uniforms of conspicuous blue, white and black, yelling tooting and chattering. They have been shy and care- 
ful. They are now tame and reckless. They troop into the pasture after the wild cherries which they eat with chattering and scolding. On vibrant limbs they give spirit rappings in imitation of a woodpecker. Then they laugh and scream about it. Hearing them we always say, "How fallish it sounds."

The blue jay has not only a whole vocabulary of his own, both in conversation, from twittering to oratory, and in calls from assembly cries and notes of warning to screams of derision and defiance, but he is an imitator in certain lines. $\mathrm{He}$ will imitate the red-shouldered hawk and the sparrow hawk and I suspect him of mixing it in conversation with the flicker. Often at this time of year I hear a subdued, rather sweet-voiced murmur in the wood as if a ladies' sewing society was just beginning to get busy pulling out the bastings. I know very well it is a convention composed of blue jays or flickers, but it is not so easy to tell which until I slip up and surprise them at it. The subdued tones of both birds in such conventions assembled are very much alike and I suspect that their polite conversation is in a common language. But I never can prove this, for they do not fraternize. The convention 
is sure to be of one feather or the other. They do not flock together. That is no doubt just as well, for I have great respect for the flicker. He is a whimsical old codger, very prone to talk to himself and go through strange gymnastics in a rather ridiculous way, but the flicker is honest. He brings up a large family in the strictest probity and I have never known a flicker to do a wrong thing. On the other hand, the blue jay is a thief, a mocker and a murderer. Just now he is living honestly on nuts and wild fruit, taking almost as many acorns as the squirrels and making a geat deal of talk about it. You would think him the most open-hearted chap in the world, but if you will watch him carefully in the spring you will learn things which are to his disadvantage. You will likely find him taking a raw egg or two with his breakfast, to the sorrow of some small bird. Later, the fledglings are not safe from him, and if you shake a blue jay up in a bag with a crow and then open the bag, two arrant rogues will fly out, and it is hard telling which will have the other's tail feathers. For all that, I rather like the blue jay. If we are going strictly to condemn all who have a liking for an occasional small hot bird, there will be but few 
of us left. At this season he is the town crier of the wood, clanging his bell loudly at every wood-road corner and announcing in strident monotones that straw hats are called in and there is an exhibition sale of fall garments at Wood \& Field's.

Even in August we get the first spray on the great wave of southward migrating warblers, and all through early September the woods are again full of their slender, flitting forms and their gentle voices. If you know your locality well you may mark the very dates of the month by their coming and going. So with equal definiteness the earlier departing of our summer residents leaves gaps in our hearts and the woodland on pretty definite September days. The cry-baby young of the orioles have hardly ceased to complain about the house, making the midsummer peevish, before the birds are flocking. They take August off the calendar with them. On the date that I miss them and the kingbirds September first is very near if not among those present. The redwirig blackbird may linger a day or two after these, but he does not wait to any more than see September arrive before he, too, is off. The bobolinks, perfectly unrecognizable 
in plain brown coats, continue to flock sparrowwise about the meadows until say, the tenth. Then they go chink-chinking down the marshes southward by way of Florida to Central America. Yucatan and the delta of the Orinoco may be lonely places in summer, but I do not think one need to be homesick there in mid-winter with all these intimate friends sitting about on the palm trees and chatting about the way things went in my meadows and woods a few months before.

As our summer residents go and the passing migrants arrive and depart we may begin to expect the winter visitants. I am looking for myrtle warblers now. Their usual date of arrival is the twentieth, and if I do not find them here it is probably my fault. The pastures are blue now with bayberries, which seem to be their favorite food. Feeding on these the myrtle warblers should be spicy, sprightly creatures, full of quaint romance, as indeed they are. The junco may come as early as this, according to the best authorities, though I confess I never have any luck in finding him much before November. The junco is a snowbird, anyway, his colors match leaden skies, and he seems to me out of place without a fellow flock of snow flakes. 
The golden crowned kinglet and the winter wren, the white-throated sparrow and the brown creeper, all may be looked for between the 20 th of September and the passing of the month, though as for the brown creeper those two ardent bird students, Frederic H. Kennard and Fred McKechnie have demonstrated that it is not a winter visitant only but an occasional all-theyear resident, they having found nests and eggs in the Ponkapoag swamp. So the list might be enlarged vastly till we found a new comer or a new goer or both for every day in this month of transition, September.

To me, though, the most potent signs of the presence of autumn are neither the migrants nor the changing foliage. They are the mysterious voices of the woodland which change at about this time often to an eerier and lonelier note. The voice of late September winds in the trees has a wild call of melancholy in it. There is a spot in my wood where an ancient pine, dead and stark long ago, lies in the arms of a sturdy scarlet oak. All summer the leaning trunk has shed bark and small limbs, silently, patiently waiting, final dissolution. With the coming of cool au- 
tumn winds it has begun to complain. On rainy days especially I have heard this low lonesome voice crying softly to itself through the dusk and been at a loss to know what creature made it. Foxes in the mating season along about St. Valentine's day make strange outcry in the wood, but at this time of year the fox if he speaks at all simply barks. A raccoon might whimper thus but there were some cries that no coon ever made. Once I stalked it for a lost child and I was long in locating the exact spot whence it came. After all it was only the complaining of the old tree as it rubbed on its support in the swaying wind, but it voiced all the loneliness of the good-byes which a thousand bright creatures have been saying to the wood these pleasant September days. 


\section{CHAPTER XVIII}

MYSTICAL PASTURES

Two century-old pasture pines shelter my favorite sleeping spot in the pasture, and croon solemn, mystical tunes all night long. If I could but, with my dull ear grown finer, some day learn to interpret these I might grow wise with the yet unfathomed wisdom of the universe. Their runes are not of the gentle, vivid life that thrills below them. Before the little creatures of the pasture world were created, before pines grew upon earth, the words they sing were set to the sagas of vast space, rhythmic runes of unremembered ages taught by the great winds of the world to these patriarchs that seem to tell them over and over lest they forget. They tower virid and virile. They stretch wide arms over the pasture people in benediction and sheltering love, but they are not of them. The reading of the deep riddle of the universe has made them prophets and seers and they dwell alone in their dignity. I may make my home beneath their sheltering shade, 
caress their rugged gray trunks and fall asleep to the mystical murmur of their voices, but I can never be intimate with them.

There is nothing of this aloofness about the other pasture people. The younger pines do not whisper solemn riddles, but are gently friendly without mystery, and so are many of the myriad creatures that crowd the spaces boldly or dwell quietly in unsuspected seclusion. Of all the outdoor world the pasture is the most friendly place, yet it is not obtrusively so and you must dwell in it long before you know many of even your elbow neighbors by sight. If you know them very well you will be able to detect their nearness by sound, oftentimes, long before sight of them is vouchsafed you. When they do appear it is usually a sort of embodiment. They materialize as if out of thin air and disintegrate by the same route. This is not because they fear you. It is simply because it has been the habit of pasture people for untold generations.

Thus it is that a lovely white moth flits often in the veriest gray of dawn just to the eastward of where I lie. It always seems as if he were a condensation out of the white mists that are born in that darkest hour when the night winds cease 


\section{0

and that runic rhyme of the pines is lulled for a time. He seems as transparent as they and is nothing but the ghost of a moth as he passes from one head of goldenrod bloom to another. Some mornings he vanishes in the amber glow that ushers in the daylight and then I think I have merely been dreaming of lepidoptera. This morning he did not appear, either in the early gray or the amber glow, and I went out to look for him. The waning moon hung wan and white in the west, a white paper ghost of a moon that had no light left in her. All the east had the clear translucent yellow radiance of the yellow birch leaves, a cool, pale gold, and between lay dead the morning mists, chilled to white frost on all the pasture shrubs and the level reaches of brown grass. Along the hedgerow of barberry, wild cherry, raspberry, hardhack, meadow sweet, sweet fern and goldenrod that deck the ancient wall I looked for the white radiance of my moth's wings in vain, and I pictured him as dead among the frozen grasses, and mourned him thus.

The day grew with all the wonderful still radiance which so often follows a frosty morning in October. The pine trees could not sing; 
there was no wind to give them voice. The still flood of golden sunshine warmed to the marrow, yet did not wilt as in summer. Instead, it informed all things with a glow like an elixir of life. To feel it well 'within one's flesh is to have a forecasting of immortality, to know that one is to be born again and again. I did not wonder that as I once more scanned the hedgerow along the ancient wall I saw my white moth clamber bravely up a goldenrod stem and begin a halfscrambling, half-fluttering pilgrimage from one to another of the hardy blooms that had survived the frost as well as he. Most of the goldenrod and meadow sweet blooms are well past their prime and are showing gray with age and ripening pappus, but here and there you find belated specimens that hold color and honey still, and on these he paused to breakfast. Then, as his wings rested for a moment, I could see that his pure white was touched with tiny chain patterns of black spots and I knew him for Cingalia catenaria, the chain-streak moth. Somehow I am half-sorry to have found him out. I am not sure but I would rather have remembered him as one of the mystical fancies of the early dawn, some pure white dream materialized out of the tenuous 
mists by the incantations of the Druid pines.

Neighborly and simple as are all the pasture people when we sit quiet long enough to see them and gain their confidence by making them feel that we are an integral portion of the place, as they are, they all have something of the mystical about them. There are four chipmunks, sleek and beautiful striped children of a this year's late litter. These frolic about on the stones and among the bushes at my very feet. They eat crusts almost from my hand. Yet they might as well be mahatmas, for in their going and coming they are as mysterious. I hear a scratching on a stone, and there sits a chipmunk. With a swish he is gone, and unless I hear the skittering of tiny feet a rod away I may not tell in what direction or how. Then, too, the skittering may be that of some entirely different creature. I prefer to think of them thus, as furry bogles that bob up out of fairy tales and bob back again to the making of a mythology that sniffs of sweet fern and bayberry and has the flavor of barberry sauce.

The tender glow of still October days seems to fill the pasture with such mysteries as this. Commonplace things are touched with the soften- 
ing haze of romance, and in the crystal stillness, the happy aloofness of the place, the consciousness goes groping for the unseen. It may be that by digging and grubbing I might unearth the veritable home of my chipmunks, trace their cunning runways under stone and through fog and brush and prove that there is nothing of the theosophist about them. But not for worlds would I do it, nor would I believe it if I found them. Therein lies the inscrutability of faith.

In the golden morning glow the sounds of the far and near world seem to come without interference from intervening space and the roar of the steam whistle on the liner at sea, eighteen miles away over rough hilltops, is as intimate as the drumming of the partridge in the swamp, scarcely more than a stone's throw away. Indeed it is less aloof, far less mysterious. Its raucous bellow is soothed to a deep musical tone by distance. It speaks of the human touch and the man-made whistle. I may measure, define, place it; know the steamer that it speaks for and the man that pulls the throttle cord. I may find the pitch, touch the identical note on guitar or cornet. I have neither wind nor stringed instru- 


\section{OLD PLYMOUTH TRAILS}

ment that will record so low a note as that of the drumming of the partridge. I count the vibrations of the first of it with ease. They speed up toward the end, but they do not raise the pitch. I know nothing in our human musical notation that will touch its depth. Yet it is a musical tone and a most goblinlike and eerie one. The partridge may be commonplace enough and his drumming but a strut of complacency and selfsatisfaction. With patience and good luck I may see him doing it and follow him from his roost in the morning till he returns to it at night. But I cannot fathom the mystery which haunts the pasture in the genial melancholy of these sunny October days, to which his drum seems to sound the marching note.

In the midday stillness when the blue sky arches over the place like a crystal bell which no winds may penetrate it seems as if the witchery grew. The warmth of the sun is like that of summer though without languor. The world is in a breathless swoon in the midst of which I wonder dreamily how this soft brown grass on which I lie could have been crisp and white with frost six hours ago. The morning waked all the hardier forest creatures who seemed to revel in 
the crisp exhilarating air. Red and gray squirrels crashed about in the tree tops making noisy merriment in their indescribable squirrel jargon. Their thrashing and chattering in the trees was almost equal to a crowd of schoolboys nutting. With them the blue jays blew trumpets and clanged bells, the woodpeckers drummed and shrieked and crows and chewinks added to the clamor. Even my chipmunks blew squeaky shrill whistles in staccato notes. The pasture was full of picnic.

The drowse of noon seemed to put them all to sleep. The pond was like glass and the black duck flock which had quacked noisily there at daybreak and drawn white lines of ripples across its black surface had gone south. Everywhere was silence.

Everywhere silence, indeed, but it was the silence only of the slumbering, deeper voiced denizens. The swoon of heat in which they lay had served to rouse other lives that the frost of the morning had silenced. There are people who never can hear a partridge drum. The vibrations are pitched below the register of their ear. There are others, far more in number who never hear the shrilling of the pasture insects. Their 


\section{OLD PLYMOUTH TRAILS}

voices are so thin and shrill that they are above the common register. Indeed they are apt to pass the average person as unnoticed as the tick of a clock in a room where one is accustomed to its presence. I do not know how long they had been at it, the black night chirping crickets which now make up for frozen nights by singing all the warm part of the day, the green day crickets whose note is pitched far higher, and a dozen other chirping, shrilling things that one never sees and rarely hears, however numerous and insistent their voices, unless something forces his attention in that direction and bids him listen. I think it was the zoon of a cicada which waked my attention, and once I heard them they seemed to fill the air with shrieking. If the drum of the partridge is the lowest piched note of which the pasture people are capable, surely the piping of some of these tiny creatures is the highest. It is very difficult to determine the spot whence comes the pulsing of the partridge's wings. It is born out of nowhere and reaches your ear from no particular direction. The shrilling of the pasture insects is everywhere and it is equally impossible to locate it. They are veritable spirit voices, these, and fill the spaces among the red 
cedars and barberry bushes, the forests of sweet fern and the fox paths that wind among the berry bushes, with invisible fays and sprites. Only the tiniest of these could have such shrill tenuous voices. Having heard them in all their uproar it is even then difficult to hold your attention on them, more difficult than with any other pasture or woodland creatures I know. There will be times when the ear refuses them and it seems as if blank silence had settled on the whole field, then after a little it will all come pulsing back to you.

How dependent these disembodied voices are upon the sun is seen toward nightfall, when the shadows begin to grow long. Where these fall across the grasses there grow triangles of silence which travel fast. Oftentimes as the point of one of these progresses you may locate a chirper by the sudden ceasing of his chirp and find him in the tip of shadow, already numb. The black crickets keep up their tune longest, singing from beneath sheltering stones and bark or fallen leaves. With the direct sun vanish also other summer pasture people who have made the warmth of the day beautiful. Under an old ap- 
ple tree the ground is yellow with the apples that it has shed and here all through the sunny hours two vanessa butterflies have alternately floated and feasted, one a mourning cloak, the other a Compton tortoise, Vanessa antiopa and Vanessa $\mathrm{j}$-album. These are late arrivals that have come from the cocoon upon a cold world and are doing their best to make good in it. Both are of a species that are hardy beyond belief and both may well winter in the crevice within the gnarled trunk of the old tree into which they creep benumbed when the chill of night begins to fall. The pasture at,midday was bright with the yellow of colias butterflies which dashed madly about from one fall dandelion bloom to another, eager to eat enough while the warmth should linger. I saw many of the American copper with them, these with a more conspicuous white margin to the tiny wings than I have ever seen before, a fall form I fancy rather than anything permanently new in this rather variable insect.

All these the first chill of nightfall sends to crevices and with them go the black wasps which have been feeding desperately in the sun on goldenrod and aster. The hornets are dead. Not 
one was about even in the middle of the day fly hunting though house flies are still plentiful. The hornets seem to be almost the first insects to succumb to the cold. The black wasps are far hardier. With their passing goes that tiny shrill uproar of the pasture and in the amber quiet of sunset the place becomes a vast whispering gallery. Tiny sounds seem to be entangled here and made audible from very far. The quack of incoming ducks a mile away across the pond sounds as if on the nearer shore. The laughter of children comes as far, nor can you readily locate the direction. At such times the mystical quality of the place deepens with the peace of it. I notice then, as I did not notice in midday, the fairy rings in the grass on the little rise of ground and am half-willing to believe I stand by a fairy rath and call the childish shouts and laughter that seem to rise from it the glee of fairies over the coming of night. After dark any one of these fairy rings now growing beneath my eyes may open and let out the troop. Their comings and goings need be only a little more mysterious than those of the chipmunks in the old wall or the Cingalia catenaria that is again flitting forth 
in the chill of gray dusk to seek what honey the coleuses and the coppers, the vanessas and the wasp have left behind.

The pale yellow glow of autumn twilight settles in deep peace upon the place. You seem to be at once in a vast silence and yet able to note all that goes on in the world for many miles about by unobtrusive sounds. To stand here in the open with the night descending in blessing upon you is to be in touch with the universe. In town night shuts you away from the rest of the world, wraps you in your own tiny seclusion. Out here it makes you one with the deep secrets of common life. The mystical quality for the time vanishes and the radiance which long holds the sky seems but the light of home, a light which is no longer within a room or shut off by the walls of a house, but the real home of all the world's creatures to which you have come at last.

As the glow fades and the darkness deepens it seems good to lie down beneath the silent pines that stretch their great arms over you in protecting fatherliness and become an integral part of the peace of the place. Sleep that comes this is deep and refreshing. Yet always with it there 
goes a subtle sub-consciousness which makes you alert to what goes on about you. Thus with the piping up of the night wind you hear once more the rapt voices of the great pines, the chanting of those weird sages of the unknown. All the mystical comes back to the pasture with the sound and the deep song of the elder trees comes nearer to finding words for you than it can at any other time. I fancy that all the wee lives that sleep and wake beneath it are part of its mystery, its longing and its unfathomable promise. 


\section{CHAPTER XIX}

WHITE PINE GROVES

A tiny brown wing brushed my cheek this morning, flitting madly southeastward on the wings of the November gale. It was a belated one of many that have scattered from the pine tops this autumn, for it was the single wing of a white pine seed and the cone harvest has been good. Ever since August the squirrels have known this and the stripped spindles lie by the score under the big pasture pines where these have left them after eating the seeds. It seems much work for small pay for the squirrel. He must climb venturesomely to the very tip of the slippery limb, gnaw the cone from its hold, then run down the tree and gnaw it to pieces for the tiny seeds within. So light are these seeds, wing and all, that it takes twenty to thirty thousand of them to weigh a pound and it is probably fortunate that squirrels do not live by pine seed alone. However, the gnawing means as much to the squirrel as the eating, for the squirrel's teeth 
grow constantly and he must continually wear them off or he dies, stabbed by his own incisors which grow in the arc of a circle. Yet the squirrel is an adept at getting at the tiny, toothsome seed and he can strip a cone of its scales far faster than I can, even if I use my knife. He holds the cone stem end upward in his fore paws which are so like hands, severs the base of the scale with his ivory shears and has munched the two little seeds that cling under the very bottom of the scale, almost before you can see him do it.

Certain wise naturalists assure us that the squirrel does not use reason in this handling of the cone, merely acting automatically by blind instinct. Yet he gets his results in the shortest time and with the least effort. The highest reasoning could teach him no more and if instinct is such a splendid short cut to the solution of problems it is a pity that it is not added to our common school course. The squirrel, they say, does it because he and his ancestors have done it in the same way for untold generations, the automatic impulse being born in him and bound to appear at the right moment, just as his teeth grow without his own volition. Yet there must have been a time when the first squirrel sat up on 
a limb with his first pine cone in his paws. Did he reason out the way to get those seeds or did he know instinctively? And if so what is instinct in his case?

For all the squirrels got so many cones that in some places in the woods the ground is fairly carpeted with the brown scales which they severed, prompted by this clever whatever-it-is that is such an excellent substitute for wisdom, there are plenty still left on the trees where they dangle from the branch tips, their scales gaping and the seeds for the most part gone. Left to themselves they have been flying away ever since September, a few at a time on dry, windy days when their single wings would scull them farthest. One might impute instinct or whatever it is to the pine tree too, she works so methodically for the preservation of her species. A year ago last spring the mother pine put forth, the beginnings of those pine cones that now dangle brown and pitchy, or drop to the ground, useless except as kindlings for my campfire. Then they were wee golden-green buds of pistillate flowers, set high on the uppermost branch tips that the pollen from the tree's own staminate blooms might miss them in its flight down the wind and thus avoid in- 
breeding. If they miss fertilization altogether they fall off. It is commonly said that the pines produce a crop of cones once in five or seven years, which is true in part, just as the statement that every seventh wave at sea is larger than any of its preceding six is occasionally borne out by the facts. I do not recall years in which the pines have failed to put forth both staminate and pistillate blossoms. Sometimes frost gets these and they fail to reproduce. Sometimes a long rain will prevent the pollen from being disseminated by the wind until its time is passed and again there is a failure in cones. Only once in a while is the season perfectly favorable, and then we get that seventh wave in pine cones and the squirrels rejoice that they can file their teeth and fill their cheek pouches at the same time. The years when there are no cones at all sending forth their seeds in September are few indeed. This year the harvest in my neighborhood has been an excellent one.

The fertilized bloom soon ceases to be a little Christmas candle on the tree top, closes its tiny scales over its growing seeds and becomes a little green cone, still sitting upright on the upper branch tip where it grew. By autumn it is an 


\section{OLD PLYMOUTH TRAILS}

inch and a half long, the short peduncle which attaches it to the branch has lengthened and thickened, but is not able to hold it wholly erect, so much has it gained in weight. At that season the young cone and its fellows have tipped over horizontal or even becomes slightly pendulous. Thus it remains through the winter, its scales pressed close to its core and to one another, defending the tender seeds from all cold and making a seemingly solid chunk of the whole. Toward spring I have known squirrels to attack these young cones, but rarely, and I am not sure whether it was because of the pressure of hunger or whether some young squirrel's instinct to sharpen his teeth on them made him a bit precocious. These adolescent cones begin growing again very early in the spring. Youth will have its way, and in this case it seems to seize on the first sap that gets as far as the topmost branch tips, compelling it to the nourishing of the young cones before it can go to the making of new leaves or even of the crop of staminate and pistillate blossoms for the ensuing summer. The cones add a quarter of an inch to their length before the blossoms of that year appear, and their weight sags them still more on the stem, 
making them distinctly pendulous. By the last of August these greedy feeders have not only ripened the seeds within the still close-pressed scales, but have multiplied their own length by four, being four to six inches long and hanging pretty nearly straight down by their weight.

Their work is done then. Fifty or more scales has each cone, a hundred or more seeds, if the fertilization has been perfect, are ripe and ready to go forth and produce other pine trees. In early September the sap begins to recede from these ripe cones, the scales lose their green plumpness and begin to dry and curl back toward the base of the cone. This gives the seed eating birds, the siskins, the pine grosbeaks and especially the crossbills their best opportunity and they eagerly pluck out such seeds as the narrow openings will give them a chance at. Between these and the squirrels the pine forests of the future are decimated before their seeds have been planted. Nature provides bountifully for the reproduction of all her favorites, yet far more bountifully in some instances than in others. A thousand young birches spring from seed, to one pine in our Massachusetts woods, and no wonder. Each birch tree ripens a thousand seeds to one 


\section{OLD PLYMOUTH TRAILS}

that comes to maturity in the great cones of the pine. Yet there are compensations for the pine tree. Barring axes and accidents it may live out its third century and yearly give more and more comfort and inspiration to mankind as it increases in dignity and beauty. The birch may give comfort and inspiration too through its grace and beauty, but it is lucky if it lasts out a score of years.

It is often a surprise to me to see how far a seed will fly with but one wing. The air currents set it spinning the moment it leaves its parent tree making of it at once a tiny gyroscope with a single blade of a propeller. Its gyroscopic quality steadies it and the whirl of its propeller tends always to lift its weight. Hence with a downward current it falls with a less velocity than the wind which whirls it, in a level breeze it often holds its own, while in the upward slanting streams of air which flow so often along and away from the earth's surface it rises easily. The stronger the wind the more the whirl of that tiny propeller tends to keep it in air and with a good September gale thrashing seed out of its cones a pine tree may be planting its kind for miles to leeward. The seed that brushed my 


\section{WHITE PINE GROVES}

cheek this morning made no such offing. Caught in a back eddy it whirled round a sunny glade for a moment, then in a sudden lull spun directly downward to the grass. There again its shape favored it. The first grass spear stopped its spinning and it dived plummet-like out of sight, the thin propeller becoming a tail that kept it head downward while it slipped most cannily to the very mould. There I found it, still in such a position that every movement, every pressure, would carry it down out of sight of all seed eating creatures where it might rest and ripen till spring when it would be ready to germinate.

Searching the pine grove and the scrubby country that outlies it, I found all stages of pine growth, from the gnarled patriarch four feet in diameter at the butt to the germinating seedling. The patriarch is nearly a hundred feet tall, and though I know many pines of his height, I have found none of quite his diameter, and I am very sure none of his age, hereabouts. His age I can but guess, yet I know that fifty years ago he was as large as he is now. Indeed, he had more wood in him, for his lower limbs that then were green and flourishing and six to eight inches in diameter have since decayed and fallen away. Re- 
cently a pine was felled in Pennsylvania which wàs 155 feet tall and 42 inches through at 4 feet 6 inches from the ground. This tree was 35I years old. I have reason to believe my patriarch is as old as that one. His height is not so great, but he has three trunks instead of one, springing from that gnarled butt at a number of feet above the ground. There are occasional trees like this one still standing in eastern Massachusetts. They have seen their children and grandchildren grow to marketable size and fall before the woodchopper's axe. They have seen one or two generations of hardwood grow between these cuttings, yet they still are allowed to remain. In cutting off wood it used to be the custom of our forefathers to leave here and there a particularly gnarled and difficult pine that the seed might furnish a growth for succeeding generations. Hence these occasional trees. I may be wrong, but I have an idea that my patriarch was growing right where he stands, a young and vigorous sapling, when quaint old Josselyn wrote about those two voyages to New England in the early years of the seventeenth century.

Josselyn gives us to understand that the wood of the white pine is that mentioned in the Scrip- 


\section{WHITE PINE GROVES}

tures as gopher wood out of which Noah built the ark. Certainly if the white pine of Josselyn's day was abundant in the neighborhood of Ararat in Noah's time he could have done no better. The wood is light, soft, close and straight grained. You may search the world for one more easily worked or more generally satisfactory. Indeed the last half-century has seen the good white pine of the world pretty nearly used up, certainly all the best of it, for woodworking purposes. Fifty years ago it was the cheapest New England wood, today it is the highestpriced, and the old-time clear pine, free from knots and sapwood is almost impossible to obtain at any price. For all the forestry we can bring into play it will take more than three centuries to grow for us such trees as were common in Maine and New Hampshire a century ago. In I 832 white pines were not rare in Maine six feet in diameter and 240 feet high. In 1736 near the Merrimac River above Dunstable in New Hampshire a pine was cut, straight and sound and having a diameter at the butt of 7 feet 8 inches. Half a thousand years were none too many in which to grow such a pine as that. Could a man have a few of these on his farm 
anywhere in New England today they would be worth more than any other crop the centuries could have raised for him.

The youngest pine seedlings hide so securely in the pasture grass and under the low bushes that rarely does one notice them during the first summer's growth. By the end of that time they are singularly, to my mind, like fairy palm trees, planted in the gardens where the little folk stroll on midsummer nights. Their single stem and the spreading whorl of leaves at the summit of it are in about the same proportion as those of a palmetto whose great leaves have been tossed and shredded by the trade winds. That so tiny a twig could become, in the passage of centuries even, a 200 -foot tree seems difficult to believe. It looks no more likely than that the "groundpine" which is taller than the seedling and fully as sturdy should some day be 200 feet tall. Yet the ground-pine may grow from its creeping rootstock for a thousand years in the shade of one grove and never be over a foot tall. Thus easily may we be deceived by small beginnings. No palm ever rivalled a full-grown pine in height and girth, yet a palm comes out of the ground 
as great in diameter of trunk and with as abundant a leafage as it will ever have.

Watching seedling pines grow year by year it is difficult to see how the great, clean trunked, old-time pines that towered over two hundred feet tall and were from four to six feet in diameter came about. The free growing pasture pine makes a round headed shrub, for the first ten years or so of its life, with abundant long limbs, and is clad in profuse foliage from top to bottom. Even as decades pass its limbs still remain numerous and though there is abundant wood in the half century old pasture pine it is of little use for lumber, for the limbs, young and old, have filled its trunk with knots. Where our present day trees have seeded in thickly and uniformly over considerable space it is different. Then as the trees grow old they grow taller, each struggling to outdo its neighbors and get more light and air. Lower limbs decay in time and in the progress of forty or fifty years we get a "second growth" pine which is fairly limbless for a height of forty or fifty feet. Give the trees another half century if you will. I know many groves that have had that and still their trunks, 
though fairly bare, show the knots where the limbs have been and produce anything but clear lumber. It may be that by giving these centuryold groves another century or two we should have something like the old perfect boles that our great grandfathers got out of the Maine woods, but I am not sure about it. I see no promise of it in the conditions under which pines grow today. Even my patriarch, though he has, I am very sure, sufficient years to his credit would cut up into only a medium quality of box boards; there is no clear lumber in him.

To produce the wonder trees of the early half of the nineteenth century the tiny seeds must have rooted plentifully in rich soil, the trees must have grown so close together as to steadily and persistently crowd out the weaker and shorter, and in the passing of two, three or four centuries we had remaining the magnificent specimens, towering two hundred or more feet in the air, their trunks without limb or knot for more than half that distance. Such conditions may account for these enormous trees, yet I am inclined to think that they do not. I am inclined to the belief that in these giant pines we had a variety of Pinus strobus which was very closely allied to 
our smaller trees, but which was not the same, just as the Sequoia gigantea of the higher Sierras is a gigantic variety of redwood, closely allied to but not the same as the Sequoia sempervirens, which flourishes nearer the coast and in the lower levels. That would easily explain why our pines, which we call "second growth," show little tendency to become such majestic or so long lived trees as the giants of a century and more in age. It is doubtful if any of the old time mighty ones remain in any remotest corner of our forests. It is a pity, too, for it is probable that in destroying the last one we destroyed a variety of pine that was far nobler than any left. 


\section{CHAPTER XX}

THE PASTURE IN NOVEMBER

In late autumn the pasture is a place of ghosts, yet ghosts so friendly withal that one walks among them unafraid. November is the month of transition when many of the pasture folk pass on to another, perhaps a better life. The bluejays stop their harsh teasing screams now and then to toll a clear, musical passing bell for these, and the nuthatches are goblin gabriels blowing eerie trumps of resurrection to which the spirits of the bee people drone a second as they wing their way onward. The great white town of the white-faced hornets is conspicuous on the blueberry bush down in the far corner and within it are the husks of a few of its once roaringly busy inhabitants. But it is very quiet and only a few of the husks remain. The others are scattered the pasture over and on them the shrubs drop red fruit and wreathed beauty or autumn leaves, in memoriam. The bumblebees, the yellowjackets and many another variety of scintillant, fairy256 
winged wild bee are with them. Their summer, like ours, is gone, and they with it, though a few of the young queen mothers are safely tucked away in warm crevices, to sleep secure until May wakes them for the peopling of the place once more.

I had thought May with its tender pastels of young color and its bubbling joy of spring song the most beautiful month in this gentle world of out-of-doors, but that was in May. Now I am convinced that November in its ethereal serenity is loveliest. May held but the vivid joy of ecstatic expectation; November speaks with the peace of fulfilment and the calm understanding of those who look with clear eyes into another world.

Between midnight and dawn I fancy the pasture folk who are still this side the pale get their farthest glimpse into the world which lies beyond. The pasture on whose bosom they dwell sleeps deeply then, its breathing not even faintly rustling the frost-browned leaves of the white oaks, not even sighing those ancient, druidical hymns through the pine tops. Sometimes as I stand with them I try to feel this bosom rise and fall in the slow rhythm of deep slumber, but even on 
such nights with the senses aquiver with expectation of the unknown I fail. I dare say the fox that slips along the winding paths at dawn and the little screech owl that calls lonelily to his mate note without noticing these and many other things in which our human perception fails. Man cultivates his brains to the dulling of his senses and builds a wall of useless possessions, attainments and entertainment about him till he hears only a few things and sees but through tiny chinks like the prisoner in a dungeon. Yet we are not altogether endungeoned. We are beginning to know our danger and cry "back to the woods," which may yet be the slogan of our next emancipation. It is a long path back for some of us and to cover it at a bound has its dangers. The earthworm shrivels in the sudden sun and to leap from the city block to the depths of the woods is to suffer from the "growing pains" of awakening, atrophied senses. The half-way ground is the pasture which once was the forest, which later was man's, and where now nature and human-nature mingle in friendly truce. In the depths of the woods the town draws me toward itself. In the city I long for the woods. In the pasture is the smiling truce 


\section{THE PASTURE IN NOVEMBER 259}

of the two forces. In the one I know best, as in most of our New England pastures, the cattle have long ceased to browse and men come only because nature draws them thither. The wild creatures seem to sense this and to lose much of their woodland fear of me. Last night, in the first promise of the gray of dawn a fox barked at my camp door, scratching at the threshold as if he were the house dog, asking to be let in out of the cold and lie at the fire. I heard the barnyard roosters faintly crowing in the distance, but a little screech owl called clearly on a limb just beyond the ridge-pole. The roosters' cry had in it nothing but self-gratulatory bombast. I know town-dwarfed men that talk like that. The owl's call was to his mate, as was the roosters', but there was no bombast in its plaint, just a mournfulness of endearment, a touch of tears at the silence and delay. After a little the other came and all the mournfulness went out of the tone. Instead there was cooing in its quality as the two talked reassuringly a moment. The first call is of six or eight notes that start ligh and tremulo down the owl's diatonic scale to a low one that has a round, flute-like quality though the whole sounds as if it were made somewhere else and 
were merely echoing from the wood. The bird is as hard to locate by sound as an echo would be and is usually much nearer than it seems when I hear him. The second call is the last note of the first one, three or four times repeated with such rapidity that it has a flute-like reverberation that is almost like a round and very musical purr. The cry of this bird has been called eerie and disquieting, but I do not think it so, even in the loneliness of the question call. The satisfied one is as gentle and cuddley as one can find among birds.

The pasture ghosts of still November nights are apt to be most portentous between the hours of midnight and dawn. The giants of eld stall. noiselessly about them, figures of gray mist out of a world of silence. Sometimes they rise like simulacrums of ancient forest trees out of grassy spots that by day were cosey with sunshine and enclosed by barberry bushes hung with coral fruit and prim cedars, spots where no tree has stood these hundred years. Anon they change to dim figures of preposterous beasts, called back to earth for a brief hour while the old moon, worn and thin, rises through them, a nebulous red cres- 


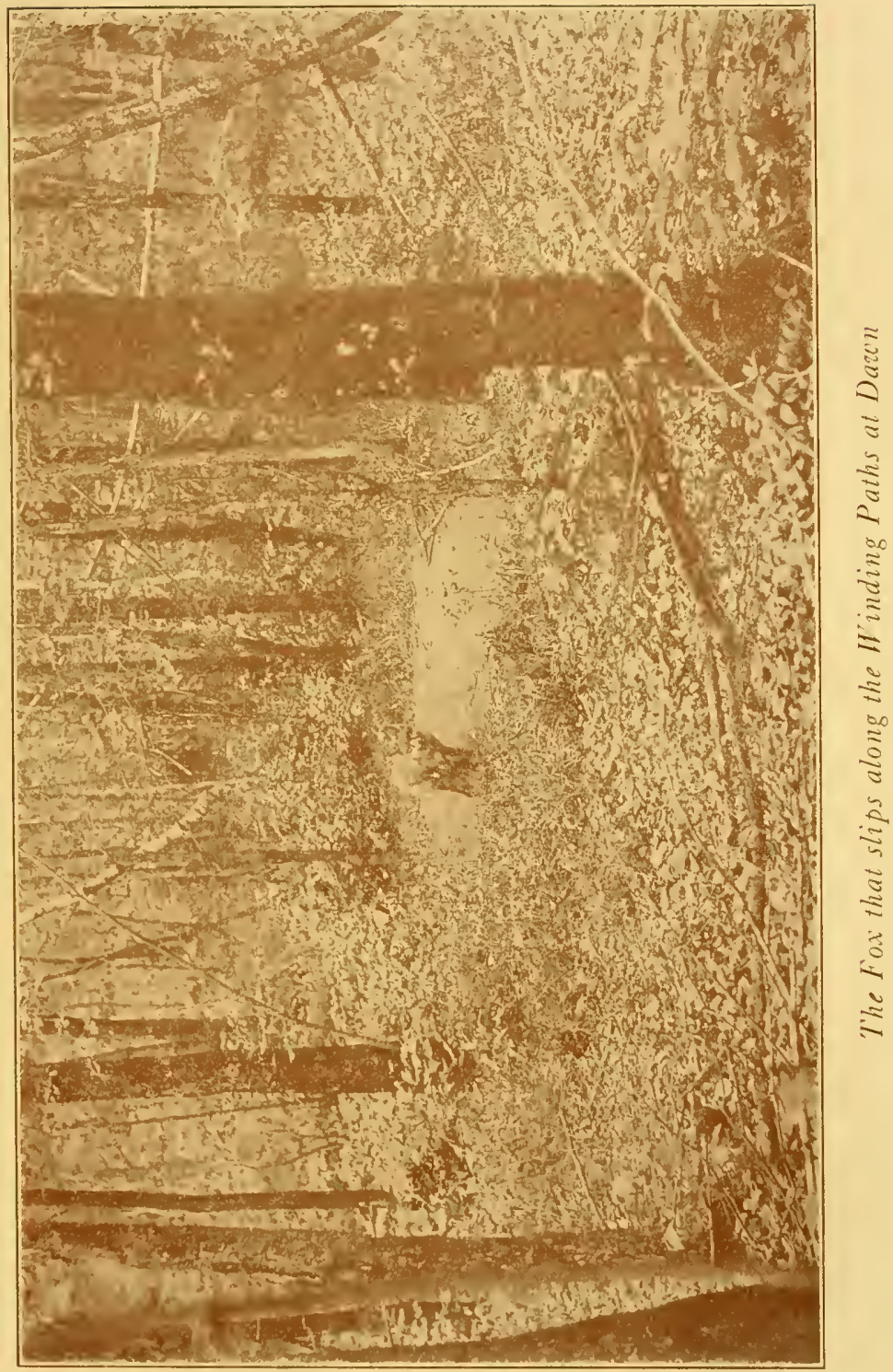




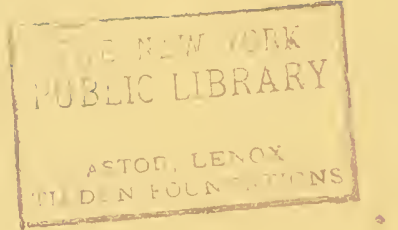


cent, and the stars fade, yet show dimly through like the moon, proving that these are but disembodied monsters. Sometimes they wait till dawn bids them dematerialize before it. More often winter, which is most apt to steal in upon us late at night in November, breaks their backs with the weight of his cold and spreads them as hoar frost upon all things below, showing us how thin and of little substance they really are. Sometimes this breakage comes with the first gleams of morning light and I feel the chill of their passing as they sink slowly to the grass. They are beautiful in their eerie suggestions as they flout my three o'clock in the morning courage, but lovelier far when they sparkle on the grass and shrubs under the sudden flare of the rising sun. I fancy that with clearer light all our gorgons and chimeras dire will become but sparkling fairies, for these certainly do. Twig and leaf and grass spear bend with the clusters of them. I see the fluff of their ermine garments, their tossing white plumes, and get the glint of their jewels, breaking up the white light into multiple rainbows that flash all the pasture world with a dainty glamour of romance. Just as the touch of winter, slipping down from the 
far north under cover of darkness, first raises these spectres, then lays them, so the sun makes their cheery, frostwork beauty a marvel of delight for a brief time, then sends it back to the earth whence it sprang and wipes away ail tears from the eyes of the shrubs and grasses that weep at losing such delicate beauty.

In those crisp morning hours of early sunlight all the ghosts are laid. The winter chill which made them has frozen them all out of the air. The twigs and leaves that gave them refuge have wept and kissed them good-by at the shout of the oncoming sun and no suggestion from the world beyond meets the eye. The ghost chill is frozen out of the sky with the ghosts; the wine of the morning is so poured through the dry air that you must drink it to the lees whether you will or not. Such mornings as you have had in April you may get in November, nor hardly can you tell without the assistance of the almanac which season it is. The bare twigs have the flush of expectancy on them, the blushing hope of new buds, as soon as the leaves of the year are off them. It may not be so bright and winning, but you will not note the difference, for it is there, painted during the ripening of this year's leaves. 
THE PASTURE IN NOVEMBER 263

If it were not that some of these still cling the illusion might be complete.

There too, to be sure, are the brown stems of the pasture goldenrod standing stiffly as if to state with grim definiteness that all rainbow hopes are folly and there will be no more blossoming for them. Their leaves are dun and sere where they have not already fallen and their tops that in early September were such soft cumulus clouds of golden yellow are but scrawny clots of brown, draggled by the tears in which the sudden sun has drowned the pasture. Yet these least of all should be pessimistic in November, for as the sun dries their tears another summer comes back to them and to us, Indian summer, which is the finest season of the year. The Indian winter of the dark hours before dawn steals down with all spears pointed for the massacre of the summer flowers that still linger unprotected, and the white magic of its own cold changes the spears to delicate, tiny frost fronds and blooms on all the outdoor world. Then, with the full day, comes Indian summer, slipping along all the pasture paths and lingering in the sheltered hollows among the evergreens. In her presence all the sorrowing plants seem to lift 


\section{OLD PLYMOUTH TRAILS}

their heads and a new blossom time comes back to the brown, despondent goldenrod. A warmth glows in its pith which is as dear as that of its prime yet has in it some of the stir of autumn crispness. Under its power the draggled clots that once were flowers lift, fluff out, bud and bloom as does the magic plant under the potent spell of the sorcerer of the Far East. You may see on such Indian summer mornings the florets of these dead goldenrod stems lifting and spreading and before your very eyes the plant bursts into bloom once more. These blooms are the day-time ghosts with which the November pastures are full, misty gray flowers that stand on the same receptacles that held the yellow blooms of late summer, but are lovelier far than the first blossoms were. Each dewy night, each rainy day, they shrivel and seem to pass but the warmth of the sun and the drying wind need but a brief hour in which to bring them all out again. After Indian summer has gone for good and the December snows are deep the stiff stems will still hold these renewing gray blooms above the drifts and make all the pasture beautiful with the ghosts of summer flowers. Nor, lovely as they are to my eye, will they be less beautiful to the 


\section{THE PASTURE IN NOVEMBER 265}

winter chippies, the goldfinches, juncos and a host of other seed-eating birds who will find them bountifully spread for their delectation all the winter through. On rainy days I like to bring these brown stems into camp and, setting them by the glow of the open fire, see them bloom as they dry out. It is a most magical flowering and to be one's own wizard is one of the delightful privileges of being a November sojourner in the pasture.

For all the Indian winter which some nights ago brought us a temperature of twenty degrees and left ice a half-inch thick on shallow pools many of the pasture folk hold their summer attire well. The wild apple trees have hardly made a change, holding plentiful leaves whose green is dulled by a little, and otherwise defies the season. The bayberry has leaves as glossy green and unmarked by any sign of approaching winter as it held in August, and though the taller wild cherry trees show autumnal tints the younger ones are still in fresh green. This tendency of the young sprouts to hold on and deny the winter I note on many young trees. The birches are in the main bare but the young wood at the very 
tops, and the tips of sprouts from the stumps of trees that have been cut, still hold leaves whose pale yellow simulates flowers, as if the trees, like the witch-hazel, had decided to bloom only at the very last moment, preferring the Indian summer to that which came to us in the full flush of June. So it is with the blueberry shrubs. The pinkyred top twigs hold their foliage still but they have sent some of their own flush up into these leaves and they hang there like pasture poinsettias, waiting to be part of the red of Christmas decorations. The meadow-sweet is in the bloom again, but instead of pinky white racemes topping the whorled green on its brown stalk the leaves themselves bloom in pale yellow with pinky flushes that make it as truly a sweet thing of the meadow as when it called the bees in July. The red alders add the coral of their berries and the barberries give the deep rich red of their fruit through which the sun shines with the ruby effect of stained glass windows. The November pasture is less profuse in its colors than it is in earlier autumn but one sees farther in it, and clearer. There are times when the gray walls of its maples and hickories stand illumined by the sunlight slanting through the vivid colors of its 


\section{THE PASTURE IN NOVEMBER 267}

remaining foliage till the place glows with rich lights and seems a cathedral in which one ought to be able to hear the roll of anthems and the chant of bowed worshippers.

Such are its changing moods on November nights and days. The constant features are the pines and cedars. Summer and winter alike these stand unchanged, types of constancy and vigor. Yet, though there is no change, one who loves them both can at a time of year see a certain variation. This comes with the spire-like cedars, that stand so erect and point ever heavenward in closedrawn robes of priestly solemnity, in early May. Then for a few brief days the glow of spring sunshine gets into their blood and they gleam with hidden bloom through the olive green of their gowns, lighting up like sombre faces that unexpectedly smile and are flooded with sunlight. The pines, too, bloom in spring, but conspicuously on their branch tips. The candles they light then serve only to accentuate the sober, dark green of their gowns. But in September the pines shed their last year's leaves that have grown a little dull and rusty with long service, and now stand forth clean and more vividly green than at any other time of year. 
The deciduous trees follow the fashions and change their suits for the prevailing mode three or four times a year, yet it is true of them that nature unadorned is adorned the most. There is a beauty in the bare wood standing revealed in November that they never had in the flush of June or the glory of early October. There is nothing in flower or leaf that can match the exquisite harmony of the bark tints, nor can the foliage in mass so please the eye as the delicate tracery of twigs and the matchless contour of tapering limbs. In the November birch or maple the dryad herself stands revealed.

It is not so with the pines. They change gowns so decorously and the new one is so like the old in its simple lines and perfect good taste that we are unaware of the transition. There is a perfection of dignity and serenity about a freegrown pasture pine that I find equalled in no other tree. These are druids of eld, if you will, harpers hoar, plucking wild symphonies from the tense wires of the storm wind's three-stringed harp. Yet the dryad dwells within them as well, and on gentler days they show her in many phases of queenly womanhood. They mother the romp- 


\section{THE PASTURE IN NOVEMBER 269}

ing shrubs, the slender, maidenly birches, the maples, vainglorious in their dainty spring colors, their voluminous summer robes, their gorgeous autumn gowns, and they do it all with a kindly dignity that endears, while they stand high above all these in their perfection of simplicity. They can be tender without unbending, and in their soothing shadow is balm for all wounds. Tonight the sky is black with rain that tramps with its thousand feet on the camp roof and marches endlessly on. The wind is from the east and the pines sing its song of wild and lonely spaces. Yet one great tree that was old with the wisdom of the world before I was born stretches a limb to the camp window, and in the flicker of the firelight I see it stroke it caressingly with soft leaf fingers and twigs that bend back at the stroke. It is like the hand of a child reaching to its mother's breast with wordless love and tenderness inexpressible. The caress makes a lullaby of the weird song above, and in it I hear no longer the lonely cry of ghostly space, but only one more expression of the homely peace and mother love that seems to dwell always in the sheltered nooks of the pasture. 


\section{CHAPTER XXI}

\section{RED CEDAR LORE}

The rough November winds which roar through the bare branches of the tall trees ride over spaces of sun-steeped calm in the sheltered pastures. Here often summer slips back and dances for a day, arrayed in all the jewels of the year. The older birches toss amber-brown beads upon her as she sways by, but the little ones dance with her, their temples bound with gold bangles which autumn gave them. The lady birches are in fashion this year most surely. Now that they have doffed summer draperies it is easy to note their scant, close-hobbled skirts and the gleam of white ankles through the most diaphanous of hose. Perhaps the birches have never worn things any other way but I do not seem to remember them so in past years. I always suspect them of being devoted to the mode of the moment and likely to appear next year in crinoline, or whatever else Paris dictates. But that is true only of the grown-ups. The birch children are 270 
the same always, slender sweet little folk, than whom summer could have no more lovely companions for her farewell romps in the pasture.

But the most virile of all the pasture's personalities is that of the red cedar. When the keen antumn winds blow and toss the plumes of these Indian chieftains they wrap their olive green blankets but the closer about them and seem to stalk the mossy levels in dignity or gather in erect, silent groups to discuss weighty affairs of the tribe. Thus for the larger ones, tall warriors that in their time have travelled far, have met many warriors and learned wisdom from the meeting. There is no solemnity about these, but there is dignity and a vivid personality which it is hard to match in any other tree. It is hard to think of these as of the vegetable world. I suspect them of standing immobile only at their will and of being capable of trooping up hill and over into some other pasture should they see fit, as readily as the woodchucks would, or any other four-footed denizens of the place.

The greater trees of the pasture do not seem to carry such personality. Many of them are like structures rather than people. The pine that 
spires high is like a church. From it as the winds pass I hear the sound of organ tones and the singing of hymns in a language that is older than man, a music whose legend is that of a world before man was. Perhaps the first pines caught the music of the morning stars when, first they sang hymns together and have made it a part of the ritual of their worship ever since. No notation that man has devised can express this music nor can any instrument which man has yet made reproduce it. Its hymnal is mesozoic. On the soft brown carpet of nave and transept of this cathedral tree one's foot falls in hushed silence and he who passes without his head bowed in reverence for the solemnity of the place goes with soul dulled to the higher spiritual influences of the woods.

On the other hand the white oaks always seem dwelling houses for the pasture folk. Beneath their wide-spreading horizontal branches I see the little folks of the neighborhood at play. Tiny pines sprout there, playing sedately as if already touched with the thought of their coming solemnity. Little brown cedars, just a few inches high, gambol on the green turf, and the barberry bushes that are still too young to wear the gold 
pendants that will come to them in future springs and the rubies of coming autumns, open their leaves there like the wide starry eyes of wondering baby girls. The kindergarten of the pasture is taught under the big white oaks and all the babies of the pasture folk attend.

The cedars make up much of the picturesque beauty of the pastures and it is pleasant to know that these beautiful trees whose personality is so marked as they group in the golden sunshine, their bronze garments beaded with the blue of their fruit, are of excellent family, they and their relatives greatly esteemed for their value and beauty the world over. The first explorers of the country spoke enthusiastically of our red cedar as one of the finest woods of the New World, praising its quality and especially its durability. Indeed the heart wood of red cedar seems to hold an oil which makes it proof against vermin and fungi. Every housewife knows the value of red cedar chips or red cedar chests in keeping garments safe from moths. Every oldtime farmer knows the value of red cedar as fence-posts. The heart wood seems practically indestructible by rot. Posts set in the ground 
for a hundred years, in which the sap-wood has entirely disappeared beneath the surface, still retain the red heart-wood intact, I dare say good for another hundred, or maybe many more.

As the tree is sturdy in its defiance of moth and mould, so it is bold in its endurance of all weathers and adaptable to all soils. It grows from Nova Scotia to northern Florida and westward to the Rocky Mountains, being replaced farther west by another species so much like it that only the expert can tell the difference. In Florida, along the Gulf coast and the Bahamas again, experts say, it is replaced by another species, but there too only the experts can tell the difference. In the beautiful province of Ontario, between the three great lakes Ontario, Erie and Huron, is a region where it grows well and is universally prevalent, and it grows alike in the limestone flats of the South and on the bleak sandy prairies and ridges of our great central plain. In the Tennessee mountains and southward into Alabama is, however, the greatest red-cedar region and the place where the trees reach their finest growth. In northern Alabama fallen trees have been found roo feet in height, three feet and more in thickness at a height of 


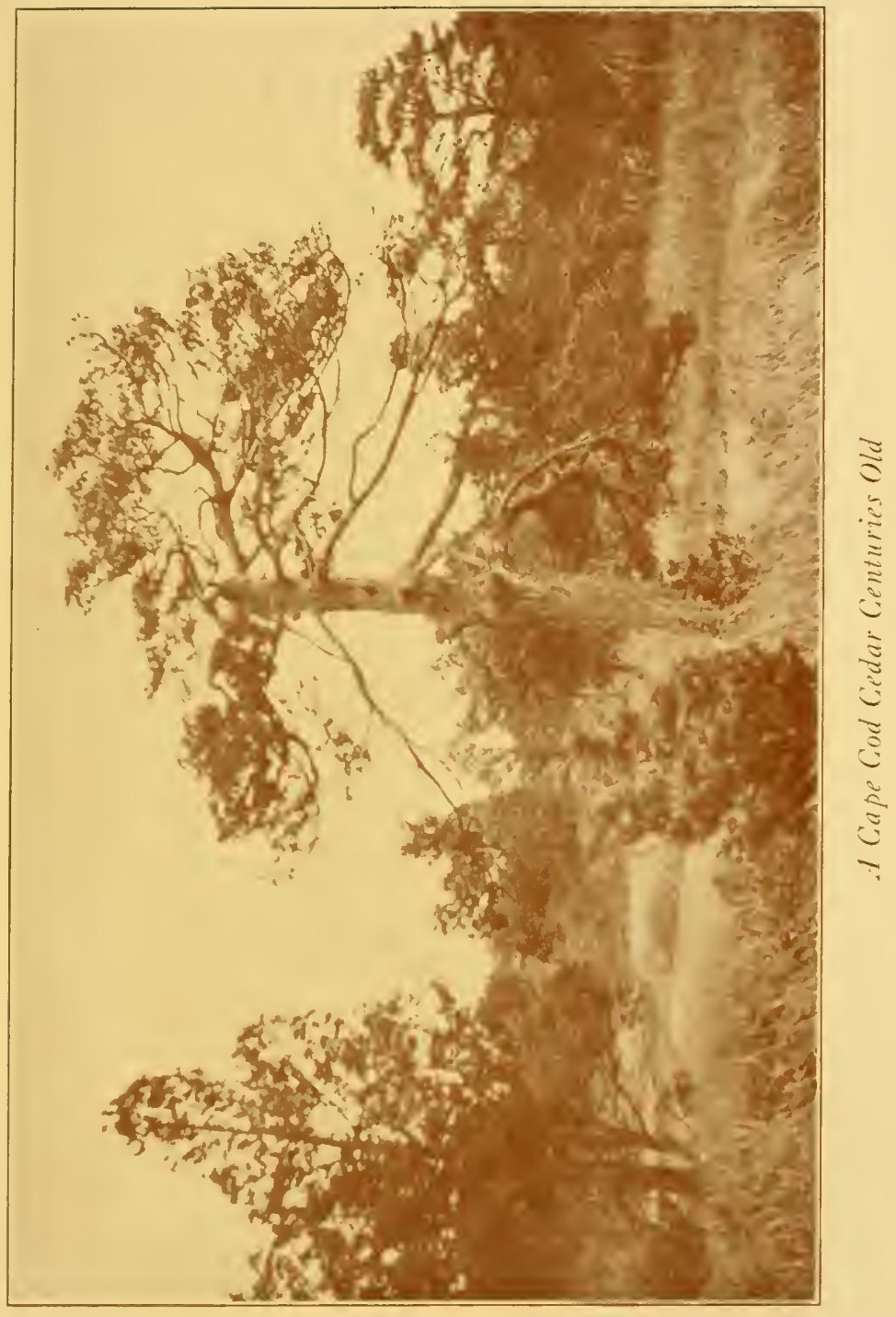




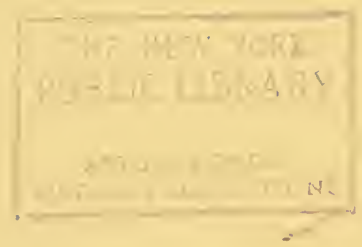


four and a half feet from the ground, and without limbs for two-thirds their height. These were, of course, trees of the virgin forests, long since removed that we and all the world might have lead-pencils. The world has tried many things for pencils, and some of them have had a fugitive popularity, but still the millions of pencils daily used are made from the diminishing supply of red cedar.

To us in New England to whom a cedar tree thirty feet high is no common sight the stories of these hundred-foot high trees seem strange indeed, and I know of but one red cedar whose diameter is as much as twelve inches. This tree is much less than thirty feet in height, however. It grows by itself on rocky ground in a pasture where it has no close neighbors of any variety. Its trunk divides at eight feet from the ground into many branches which make a round head whose ancient twigs are hoary with lichens and seem to be in the last stages of senile debility. Yet every year the old tree puts forth a crop of new leaves and defies the decay of centuries. How many years old this tree is I cannot say, but I think it very many. We readily tell the age 
of many trees by counting the rings of growth after they are cut. Cedars have been known to show an annual increase of half to three-quarters of an inch thus measured. Others have grown so slowly that only with a microscope can the annual rings be counted. I fancy my patriarch as belonging to their lodge, nor would I be surprised to learn that when its first plume appeared above the ledges Indian tepees were the only human habitations of the region.

The red cedar seems to have a power to fix itself on a rough ledge and grow there year after year and indeed century after century, that is far greater than that of any other tree. You will find them on the rocks looking seaward along much of our New England coast, some of them the same trees known in the same spots since the days of the earliest settlers, gnarled, stunted and storm-beaten, but evergreen, and glowing with a little of the gold of spring each year just the same, typical, it always seems to me, of all that is hardy and defiant in the New England character. I know such cedars on the ledges which jut southerly from the edge of the tiny plateau which is the top of Blue Hill and you may find them on many other ledges of the range. I believe these 
same trees were there when Captain John Smith first sighted the "Cheviot Hills" from the ship which brought him into Massachusetts Bay.

Far different from these are the trees which grow in the sheltered pastures where the soil is good. None of these get the round head of my ancient friend of the ledgy hill. Instead they grow a single, straight shaft, ten, twenty, or even thirty feet tall, with many small limbs curving upward and close pressed toward the trunk, making a round, tapering column of living green trees of singular dignity and beauty that look as if carefully smoothed up with the gardener's shears. All the year the pasture cedars are beautiful, and it is hard to say whether they are at their best in the spring glow of staminate delight or now when their bronze robes bear the round, exquisitely blue berries which are really cones. I have an idea the birds like them best now. The robins, the cedar-birds, and a host of others eat these berries gladly, and fly far with them, planting the seeds as they go. They find shelter in the close drawn blanket of evergreen foliage which the trees seem to wrap about them to keep out the cold and they fill the pasture with flitting wings all the month. If the season is mild and 


\section{OLD PLYMOUTH TRAILS}

the blue fruit of the cedars very plentiful the birds are likely to stay by all winter, not minding the cold so there be plenty of food.

It is worthy of note that the robin and the red cedar have the same range.

I do not blame the red men for holding the cedar sacred and ascribing to it certain mystic powers. They burned cedar twigs as incense in some of their sacred ceremonies, and surely they could have found no finer aroma. Some of tribes always set a cedar pole for the centre of their ghost dance, and they gave the tree an untranslatable name which referred to power, mystery and immortality. The Dakotas burned cedar to drive away ghosts, and in the lodge at night when anyone lay sick there was always a fire of cedar wood to protect from evil spirits. Often a cedar bough lay across the door of the lodge. It is thus that we ourselves hang up horseshoes.

On the continent of Europe, I am told, the juniper, which is a very close relative of our red cedar, is held in great veneration. Tradition has it that it saved the life of the Madonna and the infant Jesus when they fled into Egypt. In 


\section{RED CEDAR LORE}

order to screen her son from the assassins employed by Herod, Mary is said to have hidden him under certain plants and trees which received her blessing in return for the shelter they afforded. Among the plants thus blessed the juniper has been peculiarly invested with the power and privilege of putting to flight the spirits of evil and destroying the charms of the magician. Thus, even to this day, the stables in Italy are preserved from demons and thunderbolts by means of a sprig of juniper.

But the lowly juniper is not the only famous relative of our red cedar at home or abroad. Closely allied to it are the biggest trees in the world, famous as descendants from a far-distant age, yet still living and green. These are the "big trees" of the Pacific Coast, the Sequoia gigantea, which are indeed trees vastly to be marvelled at for their size and to be venerated for their age and virility, but never to be loved so well as our dignified and beautiful friend of the hillside pastures.

Abroad, the cedar of Lebanon, Cedrus libani, which Solomon glorified in his song, is an allied species, and so is the cypress, celebrated in song and story since the beginnings of time. The 
gopher wood of which Noah is said to have built his ark is believed by many to have been cypress, and, like the red cedar, Cupressus sempervirens is known to live to a very great age. Many instances might be cited of this, one of the most famous being the cypresses planted about the Mt. Sinai Monastery by the monks more than a thousand years ago and still standing there tall and green in the arid region of southwestern Arabia. The shape of these cypresses is singularly like that of many a cedar in our New England pastures, though their height is far greater.

And as the cedar and cypress are closely related in longevity, so they are in the durability of their wood. The former gates of St. Peter's at Rome were made of cypress in the time of Constantine. When they were removed and brass ones substituted by Pope Eugenius IV. they were still sound, though it was I Ioo years since they were first placed in position. Brass itself could hardly have lasted better.

While the whole Appalachian Mountain region is dotted with localities where the red cedar grows plentifully, it is only in the southern por- 
tion that the best pencil wood is obtained. The demand long ago outstripped the supply and the great old trees that were peculiarly prized for the work have in the main passed. These trees seem to ripen and mellow after passing maturity and the wood from their red hearts has a peculiar texture which makes it highly desirable for pencil wood. Only the higher priced pencils now cut in that smooth, cheesy, delightful fashion when being sharpened. The cheaper ones have the knots and inequalities in the wood which show them to have been taken from younger and immature trees. Half a million cubic feet of the best quality of red cedar was once used annually from these Southern forests in this country, and nearly a hundred thousand feet of it was exported. A generation ago one of the world's great pencil manufacturers, L. von Faber, established a red cedar forest in Germany to see what could be done to artificially supply the demand for the vanishing wood. In 1875 he set young trees a foot and a half in height over an extensive area. At the end of the century these trees had attained a height of twelve feet and were growing thriftily. But as the trees have to be nearly 
fifty years old before they will furnish pencil wood, the value of the experiment is still unproven.

But all this is by the way and is not to be compared with the joy the red cedars give to the pasture world just by being there and sending forth the beneficence of their personality upon all who come. They make the finest nesting places for the birds in summer. They feed them in autumn and in the winter's fiercest cold they wrap the warm blanket of their bronze foliage about them. Nor do I blame the Indians for investing them with strange powers. In the sunshine of midday they may seem merely friendly little trees of the pasture. If you will walk among them as dusk deepens you may feel their commonplace characteristics slip from them and the deep mystery of being begin to express itself. Then they seem like tribes of the elder world, a connecting link perhaps between the forest and the red men who but a few centuries ago inhabited it, far more real at such a time than the shadowy memories of these vanished inhabitants. 


\section{CHAPTER XXII}

\section{AUNT SUE'S SNOWBANK}

For weeks the country folk, wise in weather lore, have been shaking their heads of a morning or an evening and saying, "The air is full of snow!" No one of them can tell you how he knows it, but he knows. "It feels like snow," and that does not mean that the air is of a certain coldness or chilliness, dampness or dryness, though there is definite balance of these conditions when we say it. It means that there is in it another quality, too subtle to be defined, that touches some equally subtle sixth sense which life in the open begets in most of us. Fulminate is full of fire, but it needs a shock or sudden pressure to liberate it. So as the northerly wind drifted steadily down from the Arctic with no opposition in the air currents that would give the requisite counter pressure, the sky held up its store and we all continued to go forth, sniff, shake our heads and prophesy. The cold drifted farther and farther south till Jacksonville recorded, 283 


\section{OLD PLYMOUTH TRAILS}

shamefacedly and reluctantly, the same freezing temperature that New York had. All this while "Aunt Sue's snowbank" lifted in dun clouds a degree or two above the horizon in the southeast of a morning or a night and disappeared again. Who Aunt Sue was or why the snowbank should be hers is more than I know, but her snowbank thus appears in the sky before a coming winter storm, and has been known as such to the country folk of my neighborhood for many generations. The early English settlers of "the Dorchester back woods" brought with them many a quaint proverb and local saying. Some of these you can trace back to Shakspeare's day, and beyond. Others, like the sturdy men that brought them, have no record in the Domesday Book, but no doubt as long a lineage for all that. One of these proverbs that is probably as old as weather wisdom says:

\section{"Long foretold, long last;}

Short notice, soon past."

So as the air and Aunt Sue both prophesied for weeks without fulfilment, all the weatherwise world knew the storm would be a good one when it did come. Meanwhile the steady, increasing 


\section{AUNT SUE'S SNOWBANK}

cold put all the woodland into winter quarters. The ground froze, as we say, meaning that the moisture in it became ice to a depth of several inches, making an almost impenetrable ice blanket through which the most severe winter weather will work but slowly. Beneath this, or even in it, all burrowing roots, animals and insects are safe from freezing. Where the ground is packed hard, the flinty combination of ice and grit goes deepest, though even in exposed situations only to a depth of three feet or so. The woodchucks asleep in their burrows, the snakes, torpid in their holes, are as safe from frost-bite as if they had migrated to the shores of the Gulf of Mexico. The rootlets of small, perennial herbs may be encased in ice to their tips, but they do not freeze. The heat which the surrounding moisture gives up in changing to ice, combined with their own self-generated warmth, keeps them just above the freezing temperature and they live through it in safety. The same rootlets laid bare to the frost of a single October night die. The ice which seems to menace them is in fact their armor. So it is with countless numbers of burrowing insects. The frozen ground which seems so dead is full of waiting life which the very frost that 
threatens to kill instead protects. Last September I watched two larvæ of the rather common moth, Protoparce sexta, the tomato sphinx. Great fat green fellows as large as one's thumb, they were, each with a spinelike thorn cocked jauntily on his rear segment. They had fattened on my tomato vines until they had reached their full growth and were ready to go into the cocoon stage, in winter quarters. They dropped from the vines and began to wander hastily, but seemingly aimlessly, on the ground beneath. But careful watching showed that each was poking at the ground every few lengths as he crawled, seeking a situation that suited him. Before long each had started to burrow, going into the earth slowly and laboriously, but steadily worming a way in. Each went out of sight, leaving a hole just his own size behind him, such a hole as I might have made by pressure with a round stick. A week later I dug them up. They had gone down five or six inches, turned head upward, and there they were, each a conical brown pupa that bore little resemblance to the naked green caterpillars that had gone down into the earth a week before. Barring the accident of my spade, which neither could foresee, they were safe from cold and 


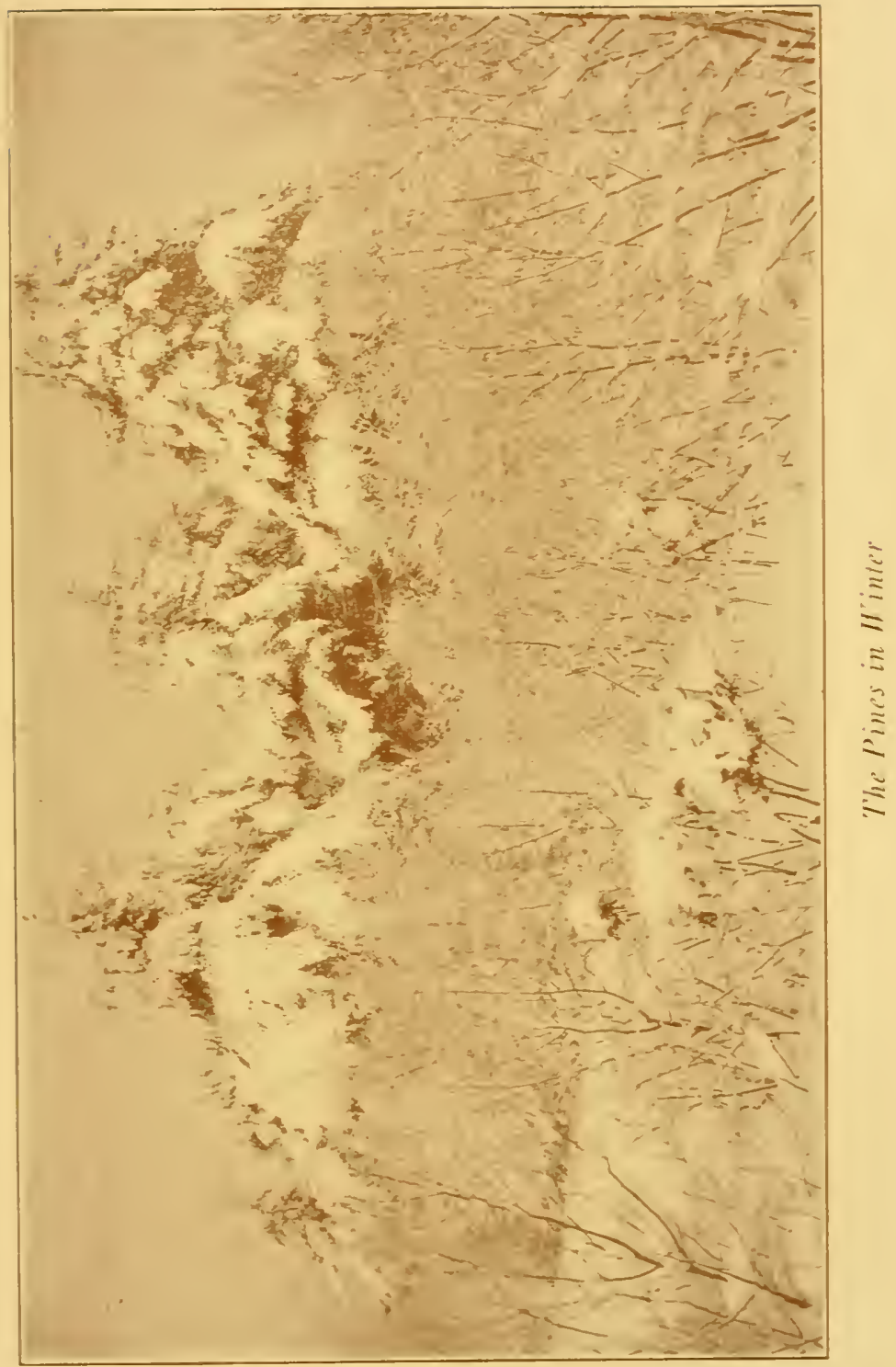



enemies. The ground would freeze solid around them, but that instead of harming them would simply put the seal of safety on their abode. Nor were they dead things to be resurrected by the Gabriel horn of spring. When I poked them they wriggled with quite surprising vigor, showing that they were very much alive and keenly conscious. They were not even asleep, else their jump at a touch would not have been so prompt.

The frost goes deepest in the densely compacted earth, probably because of the density; the fewer the air cells the better the conductor. In fluffy soil, especially in the peaty margins of the pond where the earth granules are large and loose and there is much moisture, freezing produces a singular and beautiful result. The ice seems to crystallize away from the peat in which the water was ensponged, not in a compact body nor yet in feathery crystals, either of which one might expect, but in closely parallel, upright cylinders from the size of a knitting needle to that of a slim lead pencil. These are often several inches long and stand erect at the surface by the thousand, touching but not cohering, ready to crumble to fragments at the pres- 


\section{8}

\section{OLD PLYMOUTH TRAILS}

sure of the foot but shielding the peat below from the cold. The ice on the pond may be solid enough to bear you, but when you step on this peaty edge you go down into the liquid mud beneath. Here you have reproduced in fragile miniature the same result as happened at the Giant's Causeway on the sea margin at the northeast corner of Ireland. There a long vein of once liquid basalt, freezing suddenly ages ago, left a great ridge of close-packed, vertical rock crystals running out an unknown distance into the sea.

With the good old rock-ribbed New England earth in winter quarters and the surface vocal with Jeremiahs clamoring for snow, it had to come. The incantations of these raised a witch whirl in that mysterious source of all our storms, the region along the tropic of Capricorn, in the Gulf of Mexico. Up the coast it came, with the weather bureau flying storm flags in its honor from Palm Beach to the Penobscot, boring into the freezing temperature and clear air that the North wind had spread around us, obscuring all the sky in the dun clouds of conflict. The young moon threw her clasped hands to a point of 
slender flame above her head and drowned in it. Aunt Sue's snowbank had circled the horizon and was rising steadily toward the zenith.

The sky does not give up its moisture readily this year, else the snow prophets had had their way weeks ago. The morning after that night on which the young moon drowned should have seen the air whirling with white flakes, but only in mid-forenoon did the clouds give up, and then grudgingly. All it had for us was a few granules, first-form crystals consisting of the tiniest crossed ice needles ground out of shape by the pressure between the opposing forces of the air. In the woodland the eye caught a glint of one of these now and then, but I had to go to the lee shore of the pond to know that the storm was really beginning. There the northeast wind swept the ice for a half-mile, collected these tiny snow nodules and sent them whirling along the smooth black surface to bank them in miniature drifts against the southern shore. They did not seem to come from the air, instead the ice seemed to give them up under the pressure of the keen wind. It was as if the edge of it scraped them off. The winding streams of them were very like the spindrift $I$ have seen swept in tortuous, 
level flight from the black waves of the midAtlantic by a wild sea gale. Very white they looked as they flew along the black ice, yet when I picked a handful of them from the pond margin I saw that they were anything but white. Instead they were dirty, in places fairly black. The air had seemed crystal clear for weeks, yet the snow had found in it the soot of a thousand factory chimneys and brought it to earth.

The air seems full of a magical new life always after it has been snowing for an hour or two. People who are out in it may have cold feet and tingling ears and fingers, yet they feel the intoxication of this renewed vitality till the very teamsters, half-frozen though they may be, shout cheerily to one another and laugh with the delight of it all. I fancy it is because the cleansing snow has swept all the impurities out of it in its fall, and all breathe its oxygen disentangled from soot and dust.

An hour or two more and visible snowflakes were falling in increasing numbers. The grind of winds in the upper air must have lessened a little, for the crystals came down no longer crushed into grains but with their primary, six- 
pointed star form intact. These swirled over the treetops, but straight to earth behind all wind breaks, and hung a film of flowing lace between the eye and all distances of the nearby woods. Such a curtain the makers of stage scenery imitate when they wish to let the audience see through the veil into fairyland and through it we see all beautiful things become more dainty and we know in our hearts that all wonder-tales are true, so long as we see them made real through the magic of this illusory veil. So through this floating, fairy film of snowflakes it is easy to see gnomes and sprites dancing and all the people of northland legends grow and vanish. The children may believe in Santa Claus in bright weather with the ground bare, and good luck to them. It is only when the snow falls in the woodland that we elders hear the jingle of his bells in the tinkle of ice-crystal on twig and see his reindeer lift through the air of the woodland glade and prance to vanishment over the treetops in a whirl of the storm. For a little the world is young again and Santa Claus no myth, even to graybeards in the Dorchester backwoods, when Aunt Sue's snowbank comes tumbling home through the pine tops. On such days weather- 
wisdom is justified of her children and prophets of storm have honor, even in their own country.

Most of all woodland trees, the young pines seemed to love this dry, light snow, holding up every limb and every cluster of green needles to receive it, stretching them upward as if in yearning for it. I think it is quite true that in the December cold, when there is a feel of snow in the air, the limbs of young pines do bend a little more toward the vertical. I know that the upward pointing needles do press a little closer to the stems on which they grow and thus more readily tangle and hold the ice crystals that fall upon them. The tender young shoots of this year's growth are clothed with these close-set needles for a space of a foot or more, averaging ten groups of five needles to the inch, all pointing upward to the very tip, where they press around the buds for next year's growth in a close-inverted cone. They themselves keep the cold winds in a good measure from this young bark and these prized buds. But they do better than that. When the snow begins to fall they catch and hold every flake that touches them, skewering the interstices of the crystals on their needle 


\section{AUNT SUE'S SNOWBANK}

points. The first real flakes of this storm showed as soon on the top tassels of these young pines as they did in the bare fields.

As the storm progressed, the lower needles of the spike caught such as got by the filled tops and soon all the needles of the young trees were filled with fluffy white snow, until the trees from tip to butt were no longer green but white, most royally robed in spotless purity. There was no soot in this whiteness, all that the air held had been swept from it by the very first of the storm. No cherry tree in the full fragrance of May bloom could show such dainty beauty, such endearing. florescence as these young pines on the borders of the deep wood. Nor could the pines do better for their own protection than this. Ice which encases their tender rootlets in the frozen ground and holds them warm and safe through the most severe cold, came out of the sky with the storm for the safety of tender twigs and young buds. Snow crystals hold entangled within their mass eight or ten times their own bulk of air. It is this entangled air, whether in the fluff of a woolen blanket or in a snowfall, that fends from the cold. The first clear night after a snowfall is almost sure to be a bitter one. Calm follows the 
storm, the sky is clear and the radiation from the snow-clad surface of the earth is great. This radiation lowers the temperature, and as we look at our frost-bitten thermometers in the early morning after, we do not wonder that the mercury has shrunken to the zero mark or below. But what do the young pines care? This radiation is only from the very surface of the evaporating snow crystals. Robed in this regal ermine fluff from top to toe, they hold their life warmth secure behind the entangled mass of nonconducting air and are safe from all disaster.

Our pines have suffered much from a mysterious "disease" for the last few years, and the most careful study has failed to find any fungus blight or insect at the bottom of this. We have had summer after summer of severe and long continued drought. It is now believed that this has weakened the trees so that they could not withstand the winter cold and have been "winter killed." With the drought we had several winters of infrequent snowfall. We did better last winter and the disease seems to be on the wane. Next to plenty of rain in summer, a winter in which we have frequent falls of light snow will 
be the best medicine for the pines that we could have.

It is the air entangled among the snow crystals, then, which makes the snow blanket, as we often call it, so sure a protection from cold. The ground may have frozen to a considerable depth before the snow comes, but if it stays throughout the winter there is no frost in the earth beneath it when the spring melts it away. No sooner is the ground protected from further freezing from above than the greater warmth below begins to melt the frost and change it to life-giving moisture. Because of this warmth from below the sap stirs in the trees long before the temperature in the air above the snow blanket has given it any warrant for such action. It pushes up until the frost-bound trunk denies it further passage and there waits the first brief respite in the air above. Hence in March, though the snow may be still deep on the surface and the mercury in the glass fall well toward zero at night, the fires are started in the maple sugar camps and the pails hung to the trees. We know that no sooner will the sun warm their trunks than the sap will begin to tinkle in the pails, dripping with the 
sweet promise of the spring which is already pulsing in the subsoil.

It was not a big storm, in my woods, after all. It lasted less than twenty-four hours and hardly six inches of light snow fell. Proverbs are halftruths, anyway, and "long foretold, long last" has proved less than half of itself this time. But though the day is clear and the sun bright, Aunt Sue's snowbank is lifting its purple mass in the southeast again and, with the other Dorchester backwoodsmen, I am wagging my head solemnly and joining in a jeremiad concerning a big one next time. I should like to have known Aunt Sue. I picture her as a stout, keen-eyed, wiseheaded house-mother of the old English stock. Surely she is the patron saint of the young pines and of all others who know how to enjoy a good old-fashioned winter. As such I hope someone will paint her, seated on a good big snowbank, attended by cupid pines robed in such ermine as they now wear, and with the soft radiance of a snow rainbow around her head for an aureole. 


\section{CHAPTER XXIII}

SPORTS OF THE WINTER WOODS

The time to go into the winter woods for love of them is in the still chill of dawn when the blueblack of the west is hardly yet touched with the purple that heralds the day, when the high sky in the east begins to warm from gray to gold and below black twigs make lace against an amber glow that draws one as does the flame the moth. At such a time the cold of the night may lie bitter on the open fields and the snow crystals there whine beneath the tread, but in the deep heart of the woods the warmth of the day before is still held entangled, an afterglow of the sun that waits his golden coming once more. At that hour I like to set my course eastward. The wind, if there be one, will be at my back and half its keenness dulled thereby, and the ever visible, growing promise of the sun warms almost as much as his later presence.

Our coldest midwinter nights are still and the tangle of the trees enmeshes a protecting warmth 


\section{OLD PLYMOUTH TRAILS}

that the outside cold cannot penetrate altogether. This is the outer winter overcoat of the woods. Even deciduous trees provide it and the level boughs of evergreens give layer after layer of air that fends from the cold. Even without the snow, the frost penetrates but a little way in the earth of the woods. No matter how low the temperature above the tree-tops and in the open spaces, the ground beneath the trees hardly freezes, and, if the snow comes, the moment its blanket is spread the temperature beneath it warms to above freezing and the frost comes out. Deep snows are hard on certain winter birds, but they are the salvation of many of the smaller winter animals and they provide man with one of the chief joys of the winter woods.

Going forth at dawn one has the full joy of the day before him and need leave no pleasure untasted. It is something worth while to meet the sun on such a morning. No wonder the ancient Persians worshipped him. Even his first rays enfold you with a warmth that the thermometer might not notice but which is none the less real for all that. They set the fires of the spirit burning more brightly, warming the cockles of the heart and raising the temperature of the man if 
not that of the air about him. The pleasure of the pathless woods which is to be yours for all day is sweetest in the first encounter. Toward the sun your goal glows with red fire and the woods seem in its burning to celebrate your advent. You move eastward the chief figure in the procession.

For it always seems to me as if at winter sunrise all things of the wood move forward in this matutinal procession of welcome to the coming warmth of the new day. As a matter of fact, of course, they do. The whole round earth is swinging toward the east at a wondrous pace. But it is more than that. The little winds of dawn are drawn toward the rising column of heated air beneath his glow. They come out of the nether cold of the night and it is the chill of their passing which often brings the temperature a little lower as the sun shows above the horizon, but they go to him to get warm just as the rest of us do. It may be fancy, but it always seems to me that the morning birds on their first hunt for breakfast work eastward. The first flight of the crows is apt to be in that direction and the chickadees hunt from the south side of one tree to that of the next, making the sunward side of 
the grove their rallying place. The trees in growth reach always toward the sun, stretching their limbs longest on the sunny side, and it always seems to me as if in winter they could be seen to yearn in the same direction with the fond fingers of bare twigs. I have an idea that measurements made at leaf-fall of one year and again at bud-time of the next would show this. But there is really no need. We have but to go forth in the woods of a clear, still winter morning to feel the impulse ourselves and to know that it is universal.

Out of this protecting snow at dawn come the small folk of the winter woods and to be with them there is to be at the meeting place of elves. $\mathrm{He}$ who is very wise as to their ways may see them, once in a while some one of them, or, if he be very fortunate, more than one. Without doubt to live in the woods always would be to see them all, to acquire to the full the elfin quality one's self and be one of the clan. But they become visible only rarely to the occasional visitor, these real elves and hobgoblins, and often at the best we must note their presence by the trail they have left behind. Here has passed the rabbit. Since earliest light he has been tracking up the 


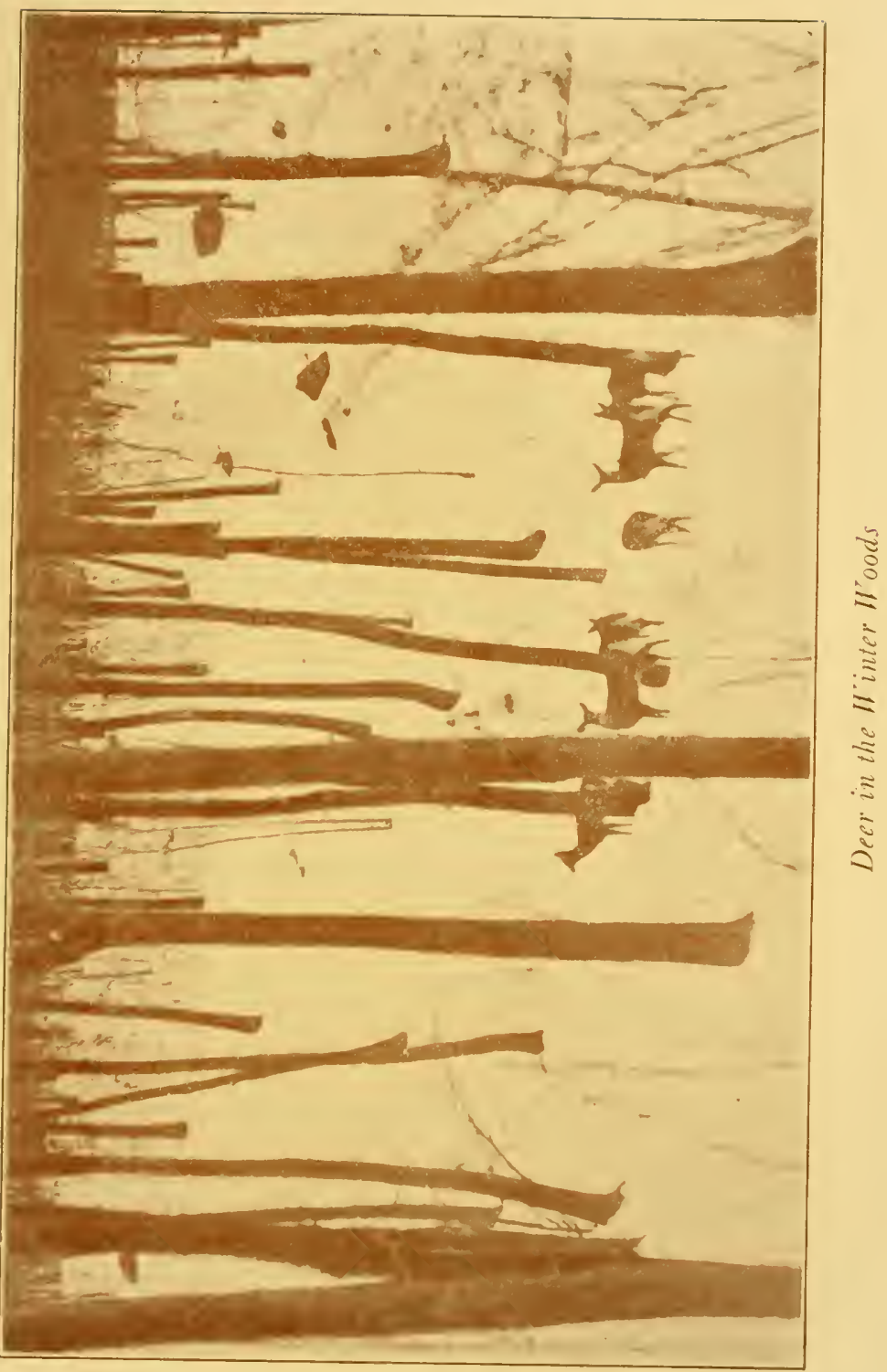




$$
\text { BIS MEN Y TRK }
$$

PUBLIC LIBKA RY

ASTOR, LENOX

TILDEN OUNDATIONS 


\section{SPORTS OF THE WINTER WOODS 301}

woods in his hunt for breakfast, but who sees him do it? There the white-footed mouse has made a curious pattern of foot-dots from his home stump to some other entrance to a way beneath the snow, the straight trail of his tail showing between the tiny foot tracks. In another place the fox has left his curious one-two-three, onetwo-three footsteps.

It is sufficient sport for the morning to take the early rabbit trails and see what has become of their maker. Some woodsman may have seen the rabbit making these tracks unconscious of supervision, but I will confess that I never have. Up North I have often watched the varying hare about his business when he had no idea that I was one of the party, but the sophisticated Massachusetts rabbit has always been too clever for me. But it is not so difficult to follow the tracks, confusing as they sometimes are in their labyrinthine route, to their end for the forenoon. This is usually a snuggery under some brush or in a tangle of dried grasses and ferns. Here I fancy the rabbit backing in and crowding out a sittingroom and then sitting in it. He will stay in this "form" until you fairly kick him out, and when I have done this, as politely as possible under the 
circumstances, I for a moment see the rabbit making tracks. Ten to one he makes them down hill, for in that direction lies the cedar swamp in whose almost impassable tangle he finds safety. Great tracks these are, too, his short forelegs just serving to catch and balance his plunge for a second, then the long hind ones coming wide of these, outside, and landing far in advance. They really look as if the animal might have made them by turning handsprings as he went.

I never see a fox by trailing him. He goes much too rapidly and ranges too far. Yet the fox has an interesting habit of following a more or less regular route. Even when the dogs are after him he often sticks to his known trail and the hunters take advantage of this, waiting along his known route and shooting him as he lopes by, easily outrunning the dogs and as likely as not grinning over his shoulder at their lumbering eagerness. It is all a game to him and if man would keep out of it the fox would always win. The way to see a fox in the woods is to figure out his accustomed route and sit cosily by it. He likes best to hunt in the dim beginnings of dawn and again at the evening twilight or by the light of the moon. But often a fox may be seen jog- 
SPORTS OF THE WINTER WOODS 303

ging along in the full daylight. The very keenness of the animal seems sometimes to work his undoing. He knows well that the dogs cannot catch him so he jollies along just in front of them over his accustomed route where he knows every possible pitfall of the way. And the hunter waiting to leeward shoots him. Had the fox had fewer brains and simply bolted in a panic as soon as the dogs got on his trail he might have lived to bolt again the next time. Once in a while you find a panicky fox that does this. When the dogs get after him he makes a straight streak for kingdom-come and the hunter with the gun waits in vain.

But on days when there is no gunning going on the fox will sometimes walk right onto a man. Recently my next-door neighbor, tramping his oak woods with no thought of stealth, rustling through fallen leaves and snapping twigs, walked round a corner of a woodpile and met a fox trotting along in the opposite direction. The animal gazed at him in astonishment for a second and then fled. My neighbor accounts for it in this way: The fox has brains. Consequently he gets into a brown study as a man will, planning affairs and studying out situations. Woodland 


\section{OLD PLYMOUTH TRAILS}

creatures whose living is conducted largely automatically are automatically alert and do not walk straight up to danger which rustles and thuds warnings of its presence. It takes a thinker to get so immersed in his own affairs of the brain as to get caught that way.

The potency of the sun on clear mid-winter days in the woods is wonderful. His rays seem to put a reviving, warming quality into the air which has little relation to the actual temperature as recorded by the thermometer. The forest catches this unrecorded warmth and with it envelops all creatures. It holds back the wind which seeks to chill, and by the time the sun is high and one is weary of swinging along the levels on snowshoes he may rest in comfort in the radiance. The recorded temperature may be far below freezing. The actual feel of the air in a cozy, snow-mantled nook is so genial and comforting that one wonders that the buds do not start. To go to the southward of a clump of dense evergreens is as good as a trip to Bermuda. On such a day the noon fire is a pastime rather than a necessity, though the making of a luxurious lunch may require heat. To tramp a spot on the snow with the snowshoes and then start a 


\section{SPORTS OF THE WINTER WOODS 305}

fire on it is to demonstrate the non-conductivity of this ermine mantle of the woods. The fire will burn long before it melts a hole through to the ground beneath, and if the snow is fairly deep it will remain unmelted beneath a gray mantle of ashes after the fire is out. There is unquestionably a primal joy in a fire thus built in the snow of the deep woods. Wherever man sets up the hearth there is home, and the first flare, the first pungent whiff of wood smoke, touch a deep sense of comfort and make the wayfarer at peace with all the world. To toast bread upon a pointed stick and to broil a bit of meat in the blaze is to add a zest to the appetite that the wholesome exercise in the keen air has stimulated. Except as a zest one's luncheon does not need the heat at such times. So potent is the oxygen of the keen air and so deeply does it reach to the springs of life that one may eat his food cold and raw as the crows do and be satisfied and nourished.

Sitting in the silence and the sun as the fire smoulders to gray ashes one may take stock of the birds of the woods by ear and eye. In the still air all sounds carry far. The cawing of the crows rings a mile across the tree tops, but these are the only winter birds one may hear far in the 


\section{OLD PLYMOUTH TRAILS}

full sunshine. The bluejays, so noisy in the autumn, are silent in midwinter. Rarely, indeed, at the depth of winter do you hear one of them utter the clear, clanging call of his race. But the wood holds them still, and as the campfire burns low they are apt to come about it, knowing well that beside deserted campfires scraps of food may be found. On such expeditions they come on noiseless wing, whinnying one to another in voices inaudible a few rods away. If one sees you he may utter a single loud note of warning, but that will be all, and the flock will scuttle away on noiseless wings as they came.

A nuthatch may come to perch upside down on a tree nearby, blowing his elfin penny-trumpet note, a brown creeper may screep tinily or a downy woodpecker knock gently at the doors of insects shut within the rotten wood, but only the chickadees are noisy. Their volubility is proof against the hush laid upon the forest by the westering sun, and you can hear them sputtering their way through the underbrush from afar. Birds in the wood mostly leave a trail for the ear rather than the eye. On such a day, even in the cold of January, you may hear a ruffed grouse drum. The seeping sun warms the cockles of his heart 


\section{SPORTS OF THE WINTER WOODS 307}

and reminds him of the brown mates of last spring, and he needs must hop up on the old $\log$ and drum for them, though there is little chance that they will heed his amorous call. The ruffed grouse has much brain even for a bird, as his ability to live in our Massachusetts woods in spite of the omnipresent huntsmen shows, but like the fox, he, too, sometimes gets in a brown study and may allow you to meet him at a corner.

When this happens to me I am always surprised to see what a fine dignity the bird has in the woods, unconscious of observation. His carriage is that of a lord of the thicket, and he seems far larger and taller than his bulk and length when put to the yardstick would show. I always think his tracks in the snow show something of the same characteristics, as if he unwittingly wrote his character into his signature, as most of us do.

All in all it is a fine sport, this hunting of the wild creatures of the wood without harming them. To bag them in one's memory or one's notebook is to accomplish that feat long desired of mankind, to keep one's cake and eat it too, while he who shoots kills his joy in the acquiring of it. 


\section{8}

At dusk of the still winter day the cold of interstellar space drops down among the treetops and seems to reflect back toward one's marrow from the snow beneath. Then I like to preface the homeward trip by one more campfire. A grove of young white pines provides the best material for a quick fire. The upper boughs of such trees so shade the lower ones that they die, but remain dry and brittle on the trees, full of pitch, making the finest kindling material in the woods. It takes but a strong pull to break such limbs off near the trunk and they may be broken into stove length over the knee or in the hands. Even in a rain the tiny twigs of these limbs will light at the touch of a match and no snow can be so deep in the winter woods but they are immediately available. They make a smokeless fire that gives off a fine aroma and much heat. In its ruddy glow is home, its flickering flames weaving an ever-changing tapestry on the gathering dusk, the black pines standing like beneficient genii watching over the altar flame in the snow.

Many a woodland thing will stand at gaze just beyond the circle of this campfire whose flare may shine back from the eyes of a wandering deer. More likely it will shine from the eyes of the only 


\section{SPORTS OF THE WINTER WOODS 309}

night bird of the winter woods, an owl. Perhaps the last greeting from the woods which the wayfarer will get as he leaves the diminishing red glow of the falling embers behind him and fares on under the keen, cold twinkle of the stars will be the questioning "who-whowhoo?" of the one of the big species of these birds, a barred owl or a great horned owl. More likely in our neighborhood it will be the gentle, quavering call of the little screech owl, a voice of friendliness out of the silence, dear to every true lover of the woods. With this voice and perhaps a gleam of the friendly eyes in the purple dusk the chronicle of the day's sport may well end. 


\section{CHAPTER XXIV}

\section{COASTING ON PONKAPOAG}

Looking backward from these days of slothful ease in getting about it seems as if the golden days of Ponkapoag were those of a generation and more ago. Then it was an isolated hamlet. To be sure, there was a railroad a mile and a half away and the venturous traveller might go north or south on it twice a day, though few Ponkapoag people were that sort of venturesome travellers. The days of the stage coaches had passed and the place was more thrown upon its own resources, especially for excitement, than it had been since they had made it a stopping point on a main thoroughfare. The railroad brought bustle to many hamlets, but it took it away from Ponkapoag and left it a sleepy hollow. Even the days of the Cherry Tavern and the Ponkapoag Inn were past and the poet Aldrich and other people of latter-day renown had not appeared to make it famous.

Now the trolley car buzzes up and down the 310 
long steep slopes of Ponkapoag Hill and the automobiles honk in endless procession both ways. The old houses stand, but a new generation occupies them and the cosey, self-centered life of the old village has completely passed. Even the people who knew its traditions of a half-century ago are gone, too, and though the Christmas snow brought good coasting I doubt if it brought many coasters to the old hill. Yet Ponkapoag Hill was once famous in the region all about for its coasting and the enthusiasm and ingenuity of the Ponkapoag coasters. On days and nights in the oldfashioned winters, when the sledding of big logs to the sawmill on Ponkapoag brook had made the course down the hill one glare of adamantine snow between deep rifts, the population of the village used to turn out; not the big and little boys and girls only, but the grown-ups even to the venerable gafiers of those days who could remember how they used to coast there before the Civil War was thought of, when the Cherry Tavern still fed scores of pleasure-seeking Bostonians on big, luscious black-heart cherries each June, and in winter the Ponkapoag Inn had its patrons from the big city not only for coasting but for pickerel fishing on the pond. 
Modern easy methods of transportation and communication have put the typical New England village, with its manly, self-reliant, selfcentered life, out of existence, and with it have passed or become decadent many of its community sports. I doubt if Ponkapoag will ever again see such coasting as it has seen, and I fancy the same may be truly said of hundreds of big hills in other towns. The sport still holds in one form or another, but it has changed. Coasting in the streets is rightly forbidden now in many communities. The chances of meeting dangerous obstructions in these days of multitudinous automobiles and omnipresent trolley cars are too great. In the old Ponkapoag days such things were unknown, and the rarely occasional sleigh or wood-sled was little to be feared. The drivers who were not coasting themselves knew the coasters had the right of way and "cleared the lulla" to let them by.

There came nights like that of the Christmas just passed when the still, dry air intoxicated the coasters and carried their shouts far under the golden moon. Then there would be a constant procession of swiftly flying forms from the brow of the hill where Blue Hill loomed clear-cut 


\section{COASTING ON PONKAPOAG 3 II 3}

against the velvet sky behind, to George B.'s blacksmith shop, at least. Certain flyers were fabled to go farther and, on perfect sledding, to make the gentle declivity clear to Potash Meadow and brook. Such as did this were famous the region through.

It is probable that the coasting on Ponkapoag Hill began with the coming of white settlers to the region, "the Dorchester Back Woods." The Indian invented the toboggan, but he seems to have used it for a sled of burden and not as a pleasure chariot. Coasting is essentially a white man's joy. No white man could have a toboggan at the top of a snow-clad hill and not immediately use it to coast down on. It is in the blood. Tradition has it that the legions of Cæsar came over the Alps, and finding the snowy slopes in front of them, immediately sat down on their shields and slid down upon the Northern races they had come to conquer. Many a New England youngster in days gone-by learned to come down a hill on a barrel stave in much the same way; he, too, with blood of the conqueror in his veins. The toboggan wasn't really invented; it grew. From that invention has worked out many devices specially fitted to the sport under 


\section{I4 OLD PLYMOUTH TRAILS}

special conditions. Switzerland has seen coasting come up from the utilitarian exuberance of the Roman legions to a sport which is international and which draws coasting experts from all over the world. They call it tobogganing, which, of course, it is not and in modern days at least never was, for it is all done on a sled with runners. "Schlittli" the Swiss call it, and though it seems a far cry it may be that our word sled has been developed from it. At least both begin with S.

Elaborate books have been written about "tobogganing" as it has developed at Davos and St. Moritz, in the Alps. The Siviss Schlittli seems to be much like what the Yankee boys call a "girl's sled," a board seat set high on skeleton runners, that I fancy were at first of the plain wood but later came to be shod with flat iron. On this the coaster sits and goes down the hill sedately, feet foremost. Thus the early Swiss tobogganing was done, the rider steering by putting out a foot to the right or left, after the fashion of the small girl today on her similar sled. Such coasting is done by careful elderly people in St. Moritz or Davos today, only they use wooden pegs held 
in either hand to steer by. The courses on which they coast are short and straight, modest little coasts such as befit their condition. Then American sports brought to Switzerland the clipper sled. It easily outdistanced the Schlittli, and for the swift, winding courses on which the races were held became the favorite. The clipper sled was born in America, and millions of boys here have them today. They are swift, sturdy, and well fitted for the sport. Their solid wooden runners were long ago shod with flat steel, but for a generation that has been superseded by spring steel, round runner-shoes that add to the swiftness most materially.

In 1877 the first of this coasting was done by the English at St. Moritz, and ever since the courses there have been steadily improving, and "toboggans" as well. The final word has become a skeleton frame of steel, the wooden runners being entirely removed from within the shoe and the rider occupying a thin board hung between the upper frames. The under part of the heavy steel runner is graoved so as to grip the ice, and the whole "rocks" after the style of the oldfashioned "rocker" skate. Thus on a curve 


\section{I6 OLD PLYMOUTH TRAILS}

the rider, putting his weight aft is able to turn more rapidly without the sled losing its grip on the ice beneath. On these the Swiss coasters negotiate $\mathrm{S}$ curves at surprising speed, and are estimated to reach sixty or even seventy miles an hour on the straight stretches of the worldfamous course. As might be supposed by any one who coasts, this speed is not made with the rider sitting on his sled girl fashion. Long ago the American visitors taught the St. Moritz coasters that the way to ride a clipper sled on a swift coast was to go "belly-bump," prone on one's belly, with a foot ready to steer at the right or left as the case might be. The stability is surer because the centre of gravity is lower, the wind resistance is less, and the method is safer and better, if it is not so dignified. The records made thus converted the most phlegmatic Englishmen at St. Moritz, and since then this has been the approved fashion.

But we have gone coasting a long way from Ponkapoag Hill. There, long before the Swiss course was thought of the evolution in sleds was going on, and though Ponkapoag did not evolve the steel-frame skeleton coaster it got up some tasty rigs of its own. Similar things were 
brought out all over New England, I fancy, on all big hills where Yankee boys coasted. One of these was the double-runner, or double-ripper as it was sometimes called, rather ominously. I meet double-runners on the hills sometimes nowa-days, but not the leviathans of old. The beginning of this community coaster is simple. It is two clipper sleds fastened together so that the rear one runs in the tracks of the front one. Then came a board placed lengthwise across the two and the double-runner was fairly begun. Later this board came to be a long plank that would hold a dozen. With that the capacity of the common clipper sled was reached. But they did not stop at that at Ponkapoag. They built two big sleds specially, shod them with proper steel runners at the local blacksmith shop, and set high above them an enormous, stout plank with foot rests and all sorts of modern conveniences.

The men who told of this enormous rig, a "double-ripper" in very truth, are dead and I can't prove it by them, so I hesitate to state the length of this mammoth coasting device and the number of people it would carry lest aspersions be cast on their veracity-and mine-but it was 


\section{8}

\section{OLD PLYMOUTH TRAILS}

very long and would carry a surprisingly large number. All Ponkapoag was wont to come out of moonlight nights and ride upon it, and its fame carried that of the little village very far. To have coasted on the big Ponkapoag double-runner was as much a thing to be mentioned boastfully in certain sections as it was in others to have been presented at court.

Bob-sled is a proper, dictionary name for the ordinary form of this device and it is used at Davos and St. Moritz for jolly family parties on the straight courses. There they equip it with a bugle to herald its approach with joyous tootings, a bridle of steel wire by which it is steered in combination with pressure on a lever by means of the feet of the steersman, and also with a curious brake which consists of a nail studded board so rigged to the rear sled that the last man can drop it down to the ice and anchor it by the grip of the nails, thereby retarding its speed. The steersman on the mammoth Ponkapoag bob-sled steered by a rope bridle and the use of his feet on a stout wooden cross-bar, and his position was no sinecure. $H e$ had at least a ton of people on board and he had no brake. 
After the leviathan slid over the brow of the hill and began its downward course there could be no slowing up, no backward sled tracks, till the end of the course was reached. He must negotiate the curve at Captain Bill Tucker's corner at lightning speed and must rightly manage the mass in mighty momentum after that, if he would not spill them all in Ponkapoag brook. The big Ponkapoag bob-sled needed no bugle to herald its coming. When it started off and especially when it swung the curve at Captain Bill's the mingled melody of delight and dismay, masculine and feminine, could easily be heard a mile, and throughout the course the chant of the coasters carried runic warning well ahead of the approaching thunderbolt. In the legend of it all I find no mention of anyone being hurt.

A great if not famous inventor once lived in Ponkapoag. James Basin came from one of the Channel Islands, a French Huguenot, with his family, and settled in the little village; it would be hard to tell why. He invented the "Basin trumpet," a curious kind of cornet with which one gets change of pitch by turning a crank with one hand while holding the instrument to the mouth with the other. This was played in the 
choir in the Congregational church of those early days. He invented many other musical instruments, one the forerunner of the cabinet organ which made a fortune for certain New Englanders. He invented a braiding machine which has since his day made millions for Rhode Island factories. It may be that he invented the strangest form of double-runner that I have heard of, and which was used on Ponkapoag Hill, but I fancy not. That I guess was an inspiration worked out on the spot by some hardy Yankee. It consisted of a great wood-sled on which half the village could be accommodated. This was hauled by horses to the top of the hill, a boy of more than ordinary courage, strength, and-it seems to me-skill, sitting on that diminutive sled in front of the great on-rushing mass and guiding it in safety to the bottom of the hill, time after time.

That a boy should have been found that would turn this trick after he had once successfully done it is not so difficult to believe as that one should have the hardihood to undertake it for the first time to find out whether he could do it or not. 


\section{COASTING ON PONKAPOAG 32I}

This Yankee Casabianca, or whatever he ought to be called, I myself knew after he had reached years of middle life and I dare say discretion. I remember well his breadth of back and depth of chest, and I think it quite true that he once lifted a barrel of flour in his teeth, but whether he got his start in physical strength steering that Ponkapoag-invented double-runner down the long hill, or whether he had to have the strength inborn in the first place to be able to do it, I cannot say.

They have a wonderful curve over at St. Moritz known as the "Cresta Run," I320 yards long and abounding in hair-raising thrills from start to finish. Hardly has the rider, lying prone on his steel-skeleton flyer, got under good headway before he comes to the "church leap." Here a swinging descent shoots him into a double compound curve where he must flash to the left and again to the right in letter $S$ fashion, helped to be sure, by raised banks on either side as he needs them. The banks help, but it takes lightning combinations of wisdom, skill and strength to make the turns in safety for all that, nor does he have a chance for a long breath be- 
fore he shoots at ever increasing speed into the "battledore" where the course turns almost at a right angle and shoots him on into the "shuttlecock" where he must negotiate another right angle. Then he must immediately take "stream corner" and be ready for his plunge into "the straight." From this again he has to take "Bulpett's corner." By this time he may be going seventy miles an hour, but "cresta leap" is before him, after which he has only to go up the steep hill which is supposed to arrest his speed at the finish. Yet even here his skill must be in full play, as riders have been known to go forty feet in air over the crest of the hill and take a fine plunge into the soft snow beyond. Indeed, the soft snow waits the venturesome rider at every turn of the famous St. Moritz course, and many there be who go to it before "church leap" is fairly negotiated, thus early in the game. The whole course, nearly a mile, is frequently made in a little over a minute and a quarter.

All this is fine to see, without doubt, and finer still to do, but do you know, if I could have my choice and could see but one, I would choose to see that leviathan double-runner of a half-century ago swinging the curve at Captain Bill Tuck- 


\section{COASTING ON PONKAPOAG 323}

er's corner, followed by that big wood-sled with the half of Ponkapoag's population on it, and hear the joyous Yankee shouts as they resounded all the way from the crest of the hill to George B.'s blacksmith shop. 


\section{CHAPTER XXV}

PICKEREL FISHING

I rarely know where the pickerel fishermen come from. They seem to be a race apart and their talk is not of towns or politics, of business or religion. Neither love nor war is their theme, but ice and fishing through it, and what happens to a man while so doing. If I suggest Randolph, or Framingham, Wellesley or Weymouth, they know them, perchance, as places where such and such ponds have a depth that is known to them and ice on which they have had adventures which they can detail. Those things for which the towns stand characterized in the minds of most men are nothing to them, but rather what bait may be found in their streams or what fish may be drawn through the ice in their territory. On days when I talk with them Boston centres about the Quincy Market, where bait is sold and pickerel are displayed, and the sporting goods stores, the merits of whose tackle are known to a nicety. Thus are worlds multiplied to infinity, each one 
of us having his own. But to step into that of the pickerel fishermen of a midwinter day adds zest to the excursion.

They are quite like the juncos, to me, these genial men of the frozen day. They suddenly appear from I know not where, share the joys of the day and place for a brief time, then walk off the ice again with their traps, going I know not whither. The next day in all probability, if it be a good one for fishing, others will come to fish in the same places and in the same way, but not usually the same men. Thus the winter wandering birds appear, take their toll of the day and the earth on which it shines, give the joy of their presence to all who seek it understandingly, then vanish. It would seem as if the pickerel fishermen were a distinct species, like the tree sparrows and the pine grosbeaks, winter visitors not to be looked for in warm weather, folk who pass from pond to pond, taking toll of all and thus learning their characteristics so definitely, though this seems hardly probable. Probably my pickerel fishermen of yesterday are artisans today, bookkeepers perhaps or salesmen, so differently dressed and occupied, their talk of such different things that I would not know them, for 


\section{6}

of all animals man alone is able to put on or take off an individuality at will, changing his countenance with his garment and his mind with his occupation. The Natty Bumpo of today may be the natty dry goods clerk of tomorrow, assuming the Bumpo with his fishing togs and making his talk of many ponds fit the clothes.

The fishermen add a touch of picturesque geniality, of excitement even to the pond, being as occasional in its daily life as the crossing of a deer or an otter or the circling of an osprey in summer. Any one of these causes a momentary stir, a local disturbance down in the depths among the regular occupants of the place, but after all it is but a momentary and local one, and the great business of the place goes on just the same near by the spots where the hand of the grim reaper is busy removing prominent citizens. For in my pond the pickerel are surely the prominent citizens, the aristocracy, for they are the largest and strongest and they live directly off their fellow fishes, which constitutes an aristocracy in any community. Minnows, perch, bream and mullet alike are busy assimilating vegetable matter, mussels, worms, insects and small crustacæ, merely to form themselves either directly or in 


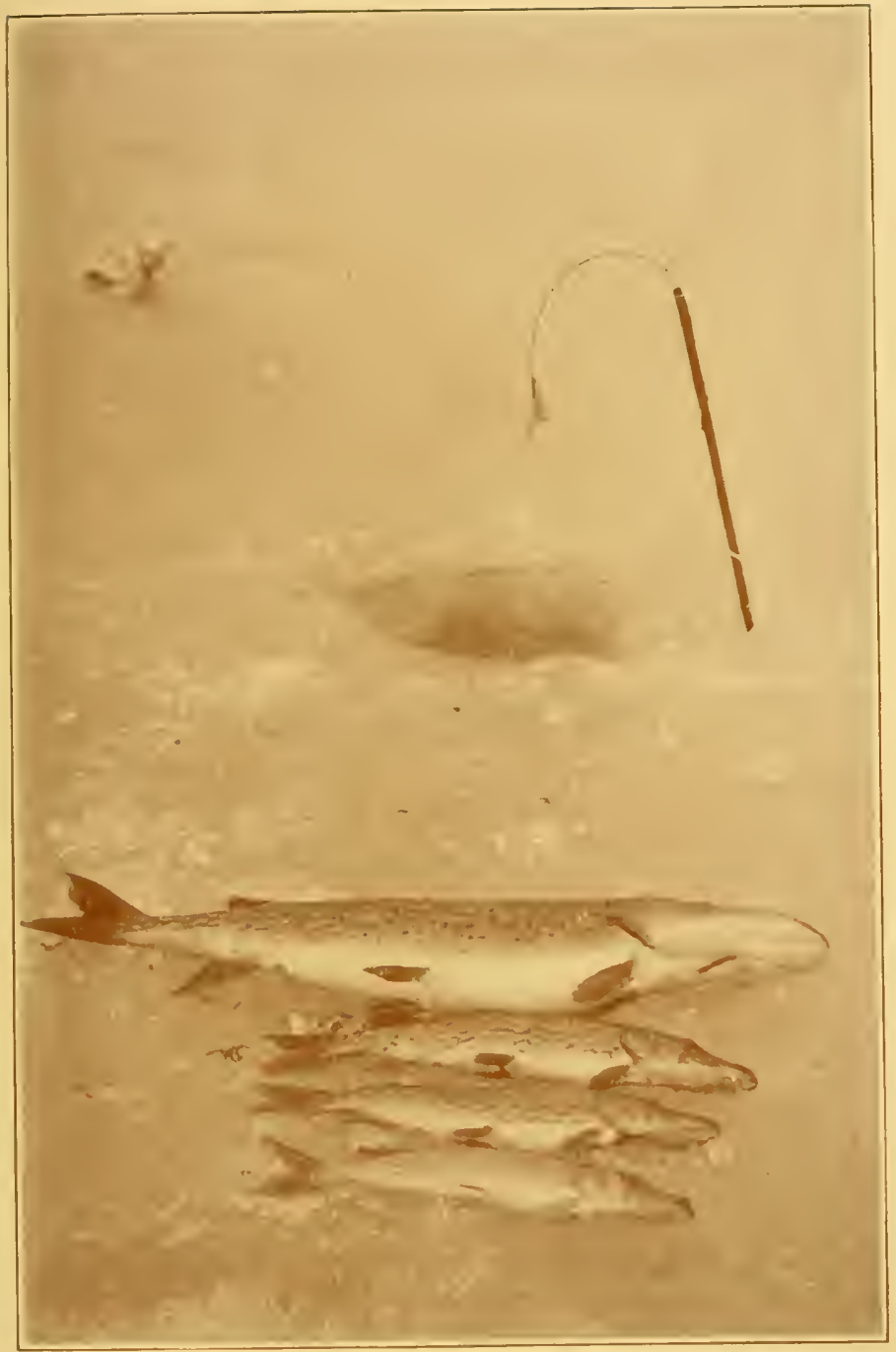

Pickerel from an Old Colony. Pond 


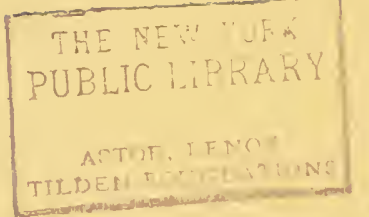


their children ultimately into titbits for the nourishing of pickerel. All the pond world knows that and its denizens tremble in the presence of these great-jawed, hook-toothed gobblers of small fry; and that constitutes a proletariat the world over.

In fishing time the loneliness of the empty levels of the ice is broken at dawn by the coming of the crows, especially if there have been fishermen the day before. Remnants of the fishermen's noon meal are quite likely to be scattered about the spot where they had their fire, and always the minnows which they, took from the hooks at leaving are there, frozen upon the frozen surface. It seems a cold breakfast to us fireworshipping mortals, but the crows take it eagerly. Often, too, before it is fairly swallowed fishermen appear, whereupon the crows flap silently but swiftly away. One knows by this action that the fishermen are just men, after all, and not a woodland variety of Peter Pan, though they merely bob up on the pond margin, or perhaps well out on the ice, loaded with their traps and tools. One never sees them coming through the wood or down the street, or getting off trolley cars or out of carryalls, these fishermen, they 
just bob up, which would seem to prove a mystic origin; though of course they are just folks and somebody knows them, as I have said.

Soon the air resounds with the xylophone music of their chopping, the solid surface vibrating beneath the blows of the axe and giving forth a clear tintinnabulation which is most delightful to the ear. It is not all xylophonic, but there is in it, too, the clink of musical glasses and also a certain weirdness, a goblin withal that seems to belong with the mystery surrounding the origin of pickerel fishermen. It is a sound to delight the ear and linger pleasantly in the memory like the sleighbell tinkling of ice crystals in a frozen wood. Stirred by this, or perhaps by the beat of the risen sun on its surface, the pond itself begins to caper a bit, musically, roaring in basso profundo a morning song of its own. The result is grotesque in the extreme. I once heard a big-chested man sing "Rocked in the Cradle of the Deep," while his accompanist jigged out an accompaniment on the highest octave to be found on the keyboard of the piano. The pond and the fishermen seen to be doing something like this.

To such quaint music the traps are set, bits 


\section{PICKEREL FISHING}

of lath standing on the edge of the hole and bearing attached to the line a red flannel flag which the biting fish will strike and carry into the depths with him when he goes off to swallow the bait. The fishermen understand well the ways of the aristocrat pickerel when he swallows a proletariat minnow. No lordly capitalist ever took in a plebeian inventor with more grace-and finality. Often the flag just drops from the support and lies on the surface of the water while the two get acquainted. The pickerel has the minnow, but his grip is not what he wants. He is particular about the way he swallows a little one, as if he feared some impending Sherman act. So, having got his fish, he waits to turn him so that the victim may head down and seem to go of his own volition into the interior department. Not until then does he run out the rest of the line. If the attorney general fisherman attempts to take him before that he simply lets go the bait and swims off, secure in his immunity bath. After he has started to really go away with his prize a steady pull is quite sure to result in his capture.

Two varieties of pickerel commonly inhabit our ponds. One, technically known as Esox reticulatus, is the Eastern pickerel, known sometimes 
as green pike or jack, but more often as pond pickerel. He is a big green fish, a golden lustre on his reticulated sides and in colonial times he was known as chain pickerel from this dark linking on his golden green surface. I do not hear the name now and I doubt if it is much, if any, used. The pond pickerel waxes fat on minnows and other small fry and in the course of a long life grows to be two feet or more in length and specimens have been caught weighing seven pounds, perhaps more. It is rather interesting to learn from the fishermen that certain ponds are apt to contain pickerel of a certain size, in the main, as if the conditions of food supply and the freshness of the water or the amount of sunshine were only sufficient to bring the most of them to a definite periad of maturity, where they stopped. But this is, of course, only a general rule, with many exceptions. One of these is the big fish. Every pond contains him and every pickerel fisherman who aspires to dignity in his class has hooked this big fellow and lost him and is able to tell you circumstantially at much length just how. Most of them know the exact location in each pond where he lurks and are confident that this winter they will win in the encounter with 
him to which they confidently look forward. Usually the fisherman hauls this monster up to the hole in the ice but is unable to get him through because the hole is too small. Tales like this, heard now and then about the fire while we watch the traps, give assurance that the fishermen are really very human after all and not of the Peter Pan species.

The other variety of pickerel is Esox americanus, the banded pickerel, known hereabouts mainly as brook pickerel, because he loves grassy streams. But the brook pickerel frequents the ponds as well, loving best those of weedy bottoms and shores and slight depth. He is a slim, little green fellow, usually not over a foot long and his dark banded sides easily distinguish him from the smaller specimens of his reticulated neighbor. The brook pickerel is found only east of the Allegheny Mountains, from Massachusetts to Florida while the pond pickerel is found from middle Maine to Florida, and west to Louisana and Arkansas. In spring the pond pickerel goes up into the ready margins as far even as the brook pickerel will and often I see him in water so shallow that his back fin sticks up, looking like 


\section{2 \\ OLD PLYMOUTH TRAILS}

the sail of a miniature Chinese junk. There he seeks the lovely little coppery swamp tree-frogs that are but an inch long and look like tailsmans carved from metal. These are his tidbits, but he will take most anything alive that is small enough for him to swallow, and when in winter he retires to the warmer layers of water next the pond bottom, his omnivorous appetite in a large measure goes with him. Hence the fishermen use many varieties of small fish for bait, all with some success.

In the spring nothing else is quite so good as this tiny, swamp tree-frog. In the winter in the majority of cases the little silvery minnow known as "shiner" is best of all. Yet, the fishermen will tell you, on some ponds the mummy-chogs which, I take it, is the still surviving Indian name for the killi-fish, are to be most esteemed as bait, and I have found fishermen fishing with young perch and dace and other hard-scaled fish, though I believe with indifferent success, nor did the fishermen themselves look to be the real thing. I fancy that people had seen these folk that fished with young perch come to the pond, perhaps even knew them by name and where they lived, and that the bait had been bought in a city market 
where they even keep young mud-fish for sale as bait to the unsuspecting, and will assure them that these are the young of dog-fish and are particularly alluring. But the fishermen, the real fishermen, know better.

The mud-fish, more properly the bowfin, is a small, dark-colored, ganoid fish which is so tough and will live under such discouraging circumstances that it would make ideal pickerel bait if the pickerel would have anything to do with it, but they will not. So in some ponds it is with the mummy-chogs which are admirably tough and live long and are lively when impaled. On the other hook the shiner is a little, silvery, softscaled fellow so gentle that he will come up to the pond side and eat cracker crumbs out of your hand. I have had shiners so tame from frequently feeding them in this way that I could handle them, though not to their own good, for the shiner is as tender as he is beautiful and just a few hard knocks, that a mummy-chog would pass with a flip of his tail, will wreck him. Yet for pickerel fishing through the ice the shiner is the king of bait and fortunate indeed are those fishermen who can obtain enough shiners to afford to use them lavishly. Properly hooked, just 


\section{OLD PLYMOUTH TRAILS}

under the after back fin, they survive fairly well and their silver wrigglings are hard for a pickerel to resist.

Though I have said that I never see the fishermen off the pond I do see them sometimes fishing for bait. They cut a big hole in the ice for this, one big enough to let that monster pickerel that is never caught come through, and through this they drop to the bottom a big hoop net. This they bait with cracker crumbs and now and then pull it eagerly to the surface, often with many shiners in it. There are small ponds that are famous for being rich in bait alone and from these the wiser fishermen draw their supply. Though the fisherman about his fire up under the lee of the pines on shore loves to tell tales of the fish of other days and other ponds he is far from garrulous when on the ice and hard at it. And usually he is too busy to talk. If the fish are biting well he tears from one end to the other of his long rows of traps, playing a fish here, hauling one out there, setting a trap that has been sprung by the wind or the too eager wriggling of the bait, and on most fishing days, whether the fish bite well or ill, he has to constantly make the 
rounds of his holes, inspecting his hooks to see if the bait has escaped or been stolen, handling new ones in the icy water and skimming the young ice from the holes across his fishing. Miles a day he runs in the keen air with his bait pail and skimmer and however many fish he catches I am quite sure he eats them all at the next meal.

And not all his catch are sure to be pickerel. Down below there in the twilight of the warmest water next the bottom are perch and dace, bass and eel, and all these are likely to hunger for shiner. The largest eel I ever saw caught came up through the ice in this way and I have even known the clumsy and stupid sucker to come out of the hole on the hook, making the fisherman think for a moment that he had hold of the one big pickerel of that particular pond. I cannot conceive of a sucker actually attempting to eat a shiner, even when impaled, impeded and wriggling, so such must have come by the hook in some other way, probably accidentally caught as they came by.

As for that monster fish, there are times, even when the fishermen are not telling me about him, that I believe he exists. Besides the two vari- 


\section{OLD PLYMOUTH TRAILS}

eties of Esox mentioned there is another which is common to all suitable waters of North America, Europe and Asia. That is Esox Lucius, as Linnæus named him, the common pike. This fish is very like the pond pickerel in appearance and he sometimes grows to weigh forty pounds or more and to a length of four feet. Such a one might well be too large to come up through the hole which the fishermen have cut for his little cousins, the brook pickerel. It is quite possible that one of these Jonah-swallowing leviathans rules the pickerel in each pond kingdom, like a Morgan among millionaires. Of the pike, which he loved well, Isaac Walton has much to say and I cannot refrain from quoting a few of his most loving phrases, which are those which tell how he should be cooked.

"Keep his liver," he says, "which you are to shred very small with thyme, sweet marjoram and a little winter savory; to these put some pickled oysters and some anchovies, two or three; both these last whole, for the anchovies will melt, and the oysters should not; to these you must add also a pound of sweet butter which you are to mix with the herbs that are shred, and let them 
all be well salted. If the pike be more than a yard long then you may put into these herbs more than a pound, or if he be less, then less butter will suffice. These being thus mixed, with a blade or two of mace, must be put into the pike's belly, and then his belly sewed up so as to keep all the butter in his belly if it be possible; if not, then as much of it as you possibly can; but do not take off the scales. Then you are to thrust the spit through his mouth and out at his tail; and then take four or five or six split sticks or very thin laths and convenient quantity of tape or filleting; these laths are to be tied around the pike's body from his head to his tail, and the tape tied somewhat thick to prevent his breaking or falling from the spit. Let him be roasted very leisurely and often basted with claret wine and anchovies and butter mixed together, and also with what moisture falls from him into the pan. When you have roasted him sufficiently you are to hold under him, when you unwind or cut the tape that ties him, such a dish as you purpose to eat him out of, and let him fall into it with the sauce that is roasted in his belly; and by this means the pike will be kept unbroken and complete. Then to the sauce which was within 
and also that sauce in the pan you are to add a fit quantity of the best butter and to squeeze the juice of three or four oranges; lastly you may either put into the pike with the oysters two cloves of garlic and take it whole out when the pike is cut off the spit; or to give the sauce a haut-gout, let the dish into which you let fall the pike be rubbed with it. The using or not of this garlic is left to your discretion."

Surely the pike is the king of fishes when he is cooked in that fashion, and I doubt not a pond pickerel thus served becomes at least a prince. "This dish of meat," says Walton, "is too good for any but anglers or very honest men." I am sure it is none too good for pickerel fishermen, and when I think of it I do not wonder that they are fat. 


\section{CHAPTER XXVI}

\section{YULE FIRES}

The Peace of the Gods which our Aryan forbears knew descended at Yuletide hovers near always as we watch the Yule log, whether in the keen air under the stars, or in the tapestried shelter about the carefully fended hearth. Man loves warmth, but he worships flame, as he always has since he first saw it fall from heaven, though few of us now make our prayer to it. Its flicker in the night will draw us far; nor are we alone in this, for all the wild things of the wood come as well and toss back its flare from eyes wide with wonder. As they stand at gaze before it, unwinking, so do we, letting its wordless message touch the primal fonts of peace. Around the camp-fire, whecher without or within, all men are brothers and the breaking of bread and the tasting of salt are but the more formal symbols of fellowship. Man has made God in many images besides his own, but none has found a finer symbolism than the ancient Persians, who 
saw in flame the most ethereal expression of beneficence and purity. The race has grown older now and we strive to outgrow what we call childish things, yet we get new strength for dwelling in our higher levels of mature thought by dropping back now and then to the primitive customs and touching with smiling reverence the ancient forms of expression. Here in America is the smelting pot of nations and we are uniting once more in one race the scattered children of the Aryan stock. Each child brings as play what was once worship-Saxon, Celtic, Greek or Latin, all uniting again in the Christmas celebration and each bringing his fagot for the lighting of the Yule log, which burns on Christmas Eve.

Nor does it matter to us now from what tree that $\log$ is cut, though once it did. The ancient Aryans who were forefathers of us all lived very near to nature and all their thought was built upon her moods. Our Christmas tree with its lighted candles and its glow of tinsel ornaments is but a tiny image of their sun tree, which began to grow with the first lengthening of the days. They imaged in this dawning light a pillar of fire like a tree trunk that grew and spread over the heavens, bringing through spring all the 
beneficient gifts of summer. The rays were twigs, the glowing clouds foliage, and the sun, moon and stars golden fruit that hung from these celestial branches. Out of this as the race grew came also many another romantic symbolism of cherished belief. Among the glowing sunset clouds was hung the golden fleece of the Cholchis. The golden apples of the Hesperides grew there. The very lightning flash was but a celestial mistletoe growing mysteriously upon the limbs of this flame tree as it grows on the oaks in the forests beneath which they hunted. Secure in our better beliefs, we call their worship superstition, but it is well that they had it. It was the groping expression of imagination without which we are no better than the beasts and would never find the really spiritual for which wo still seek.

The most perfect descendant of this sun tree was the world-ash of the Scandinavian mythology, the "Yggsdrasil" of the Edda, in which it is described, with the many mystic rites which grew up about its worship. Hence in Western Europe the proper Yule log was the trunk of an ash tree bound with as many green hazel withes as possible, the hazel being also a sacred tree with these people. As late as thirty years ago, and I 


\section{2 \\ OLD PLYMOUTH TRAILS}

doubt not still, the Yule log was thus put to burn on Christmas Eve in many an English fireplace. There some part of it was to be kept smouldering, however low the fire might get, and the blaze of the next day was to be relighted from it for the twelve days of Christmas. Moreover, from a portion of this log should be relighted the Yule fire of the next year, that its magic might be perpetual and thus all evil spirits be warded from the house. Not a bad superstition this, the brand standing as a constant reminder of the spirit of peace and good will lighted in the Christmas fire, not to be forgotten till it is kindled anew by the relighting of the blaze on the hearth a year hence. Here in New England we come, little by little, back to these kindly old customs that mean so much when the outward observance is informed with the thought which it represents. The old fireplaces which were once ignominiously built up with bricks to give free draft to the air-tight stove in its hollow materialism are being reopened, and in them again we light our Yule fires. Nor is the spirit banished with the season. The blaze from the burning $\log$ on the open hearth is the kindliest welcome that a room can give to him who enters it. In it the rough rind 
of our puritanism burns away and the glow within shines forth as we sit about this primal altar of our race, fire-worshipping.

It was the olden custom for host and guests to watch the first burning of this ashen fagot, and as the hazel withes one by one burned away the severing of the bond was the signal for the passing of the flagon, the loosing of the genial hospitality pent within the breasts of all and set free with the flames. Perhaps many who took part in these rollicking ceremonials thought they cared merely for the cakes and ale, but even they were self deceived. It was the genial freeing of the spirit of Christmas good-will to all, the fellowship that touched deepest, though they may not have formulated the fact even in their thoughts. No wonder that the children, whose clear sight is unblurred by too much learning of things which are not so, knew that to this fond fire on Christmas eve must come that patron saint of gifts, Santa Claus, even though, the house being locked, he must climb down the wide chimney to reach it. We have forgotten the shoe, which in the folk tales of our earliest forbears of the North European forests was the symbol of mutually helpful deeds of love. The children of these days placed 
it by the Yule fire, that Santa Claus might load it with gifts. Nowadays we hang the stocking in its stead, perhaps because it holds more.

I do not take it kindly of old Ben Franklin that he, almost an hundred years ago, with his Poor Richard wisdom taught us to economize our fuel by shutting up our fire in stoves, for what we gained in the flesh we lost in the spirit, and it is good that in the modern house, however mechanically complicated the heating apparatus, we build fireplaces once again that our souls may be warmed with the sight of the flame. The impulse to worship fire still lingers within us and though we have better creeds than that of Zoroaster and truer spiritual ideals than the Parsees we can have no more appealing symbol of the purely spiritual than flame. Phlogiston might well be another word for soul and we are unkind to the old philosophers to take them too literally. The alchemists were dreamers rather than doers after all, and though it is the fashion to laud the doers it is often the dreamers that see most clearly. As the flame leapt upward from the burning wood they saw in it a rare, pure, ethereal substance which they called Phlogiston. 
Nor did they yield their theory when Lavoisier claimed to disprove it by burning phosphorus in oxygen and weighing the result, which was heavier than the phosphorus had been. Thereupon the world derided the alchemists and lauded Lavoisier whose experiments laid the foundation for the intricate science of modern chemistry. For all that, science gives us the truth only from one angle and the science of one age is often disproved by the science of the next. Modern chemists may agree on what happens when phosphorus burns, but many a theory of Lavoisier's day has been disproved in its turn. A thousand scientists have declared flying impossible to man, yet today men fly. Lavoisier was right, no doubt. Combustion is the combination of an element with oxygen. He proved that with his chemist's balance. Yet how did he prove that some imponderable element does not leap from wood in flame? As well say that when a man dies the spirit has not left the body because he weighs the same. Watching the falling emibers of the Yule $\log$ leap into flames before they turn gray, I am apt to think that the intuition of the alchemists touched a truth that the chemical apparatus missed. You cannot meas- 


\section{OLD PLYMOUTH TRAILS}

ure its reaction on the mind of man or weigh the results, but they are there.

Wood was the sole fuel of the New England pioneers for two centuries. In fact in many a remote farmhouse it is today, and the fathers soon found by use which kind lighted quickest and which burned longest and with the most steady heat, facts which the subtle analysis of the chemists only confirmed. The conifers light most readily and burn rapidly with the greatest heat in a given time. The hard woods burn longest, some of them retaining fire for a surprising length of time under just the right conditions. The woodsmen will tell you that the pines light easily and burn fiercely because of the pitch they contain. This is true but the chemists have added another reason. Pine gives off much hydrogen when heated and this light and inflammable gas gives much flame. Even in pine wood which does not seem resinous to the touch there is much of this volatile inflammable material and a good store of pine kindlings is a first requisite in every well ordered country household. Of the hard woods hickory is easily king as a fire holder. Yet the oaks, white and red, and the sugar and 


\section{YULE FIRES}

black maples are not far behind in value. Our American white ash and elm rank well up with the oaks, so does beech, while the softer woods fall behind. Moreover, trees grown on high, droughty, barren soil show greater heating power than those of the same variety which happen to stand in rich, but moister soil.

Long ago an American chemist confirmed what the practical experience of the woodman had already decided. Marcus Bull's table of the heating value of American woods is as follows: Shagbark hickory, IoO; white oak, 8 I ; red oak, 68 ; sugar maple, 6o; red maple, 54; white ash, 77 ; chestnut, 52 ; white beech, 65 ; black birch, 63 ; white birch, 48; pitch pine, 43; white pine, 42.

Wood, according to the chemists, is a carbohydrate and the greater the proportion of carbon which it contains the greater is its heat-giving value, the greater the proportion of hydrogen the greater the output of ruddy flames. Yet chemists, who are so sure the alchemists had no ground for their beliefs, do not always agree among themselves. Professor Bull's table of the heat-giving properties of the various woods has been declared inaccurate by other chemists, in spite of the fact that experience in actual use 


\section{OLD PLYMOUTH TRAILS}

bears it out in many particulars. Again, either the chemists of Europe are at variance with ours or else their trees are, for Gottlieb's table of the heat-giving properties of European trees of similar varieties turns ours upside down. Gottlieb's table of calorics puts oak at the bottom of the list and pine at the top. It is as follows: Oak, 46.20; ash, 47.II ; elm, 47.28; beech, 47.74; birch, $47.7 \mathrm{I}$; fir, 50.35 ; pine, 50.85 .

There is a certain interest in all this, but to him who lights the Yule log on Chrismas Eve it probably matters little. He knows that pine will kindle his fire readily and that one of the hard woods will hold it longest. He knows that out of the leaping flames, whether they be composed of phlogiston or incandescent hydrogen, loved fancies flashed into the minds of the elder race, born of the flicker of flame on the imagination of a primitive people, backed by dark forests, night and wind-riding storms. If he have the hardihood let him light his Yule $\log$ in the winter twilight of the snowy woods. He will do well to pick a spot where a dense growth of pines shelters him from the wind and a steep ledge makes for him fireplace and chimney at once. Then it does not matter if the snow is 
deep on the ground and the air filled with flying flakes; his hearth may soon glow with comfort. Even from a materialistic point of view the ancients did well to worship fire. Out of it was to come more or less directly all the material progress of the race toward civilization.

The pines, whose presence in the woods is always a benediction, stand ready with the best fire kindlings in the world. Their twigs light at the flare of a match. The larger limbs will fire from these and send flames leaping high. On a fire well started thus between backlog and forestick he may pile such dry, hard wood as he has at hand. The forest will give him plenty if he is on friendly terms with it. The forest will give him more, too. Out of its mysterious darkness will slip easily into his mind the old-time loved and half-forgotten legends that grew out of the winter night in the twilight of the early days of the Aryan race. At the time of the winter solstice it was the custom of the gods to leave their dwellings in heaven and come down to earth. In the shout of the wind in the pines he may well hear Wotan riding overhead in his gray cloak and broad-brimmed hat pressed low over his face. 
He may glimpse his white steed whirling by and see plainly in the upflaring light of his fire the army of white souls that scurries behind the winter-god as he rides on his way. Black eagles fly with him and the wolves of the air gallop on before. The world-ash was a gigantic evergreen in whose branches were the abodes of giants and dwarfs as well as men and gods. Screened by night within the forest this tree may well be near with the springs of being and non-being within its roots and the Nornen sitting by, silent and grave. He may catch the gleam of the eyes of Loki as the firelight glints on the frost crystals among the snow-laden branches. Thus easily does a thousand years of civilization slip from us when face to face with night and the forest.

Yet if night and the winter ghosts of old ride just beyond the circle of his firelight, within it he is in the magic ring of comfort and safety. Around the Yule logs of centuries the race has warmed its heart as well as its hands, its soul as well as its body, and the old gods of terror have become the saints of good will. Out of the winter night Wotan steps into the light of the Yule fire, transformed into St. Nicholas, the very spirit of genial generosity. If we will go from 
our forest vigil to the hearth in any home we will find the world-ash, no longer weird and awesome with the fates sitting silent at its foot, but transformed into the very symbol of light and happiness and cheer, the Christmas tree. In the light of twenty centuries around the Yule log we have forgotten to be afraid and have made out of our weird dreams friendly fancies. Where once the fearsome dragon twined about the sun-tree we simulate his folds with strings of pop-corn. The unquenchable lights that flamed upon its twigs are now twinkling candles. The sun, moon and stars that once were the symbolic fruit grow again in tinsel ornament and, where we follow the legend closely, Eikthyner the stag, Heidrun the goat, Freyer's boar and Wotan's ravens and wolves, are hung in tiny effigy as confectioner's sweets. Thus with the Christmas tree alight and with the Yule log on the hearth we symbolize the old worship of the sun-tree and of fire through which we have grown to the better faith of which Christmas is one great commemorative festival. 



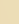




THE NEW YORK PUBLIC LIBRARY REFERENCE DEPARTMENT

This book is under no circumstances to be taken from the Building

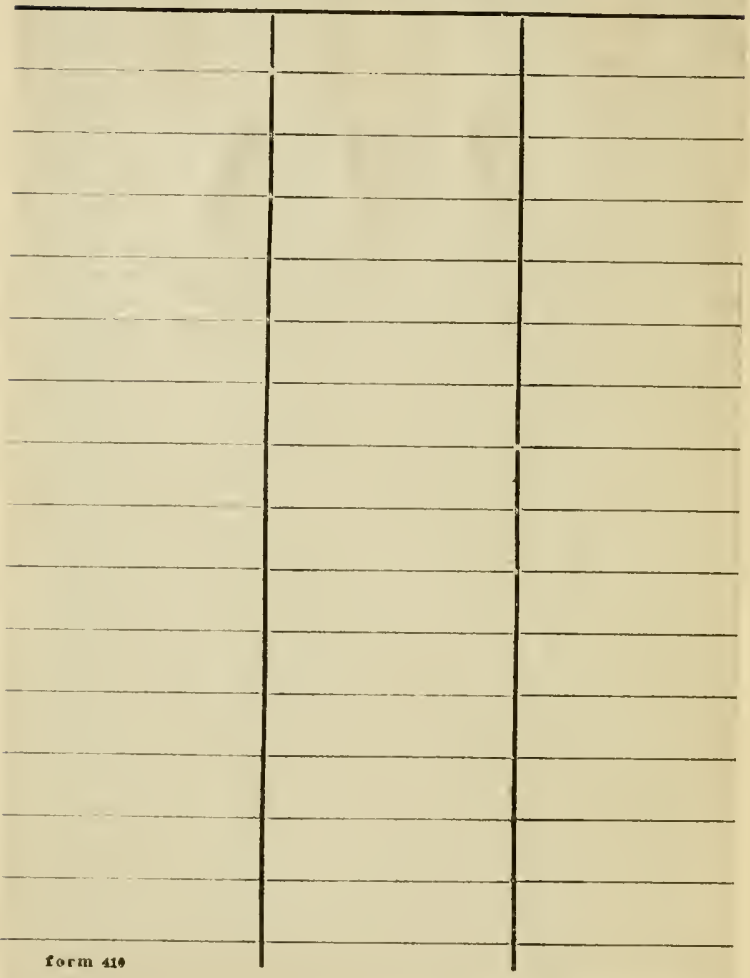



